BNL -52322

1

\title{
BROOKHAVEN NATIONAL LABORATORY SITE ENVIRONMENTAL REPORT FOR CALENDAR YEAR 1990
}

\author{
R.P. Miltenberger, B.A. Royce, and J.R. Naidu
}

Contributors:
H. Bernstein
D. Morganelli
H. Bowen
D. Paquette
M. Collins
G. Schroeder
C. Decker
T. Sperry
P.R. Hayde
J. Steimers
R. Lagattolla
M. Surico
R. Litzke
J. Tichler
W. Litzke
R. Thompson
A. Meier

January 1992

SAFETY AND ENVIRONMENTAL PROTECTION DIVISION

BROOKHAVEN NATIONAL LABORATORY UPTON, LONG ISLAND, NEW YORK 11973 


\section{DISCLAIMER}

This report was prepared as an account of work sponsored by an agency of the United States Government. Neither the United States Government nor any agency thereof, nor any of their employees, nor any of their contractors, subcontractors, or their employees, makes any warranty, express or implied, or assumes any legal liability or responsibility for the accuracy, cumpleteness, or usefulness of any information, apparatus, product, or procese disclosed, or represents that its use would not infringe privately owned rights, Reference herein to any specific commercial product, process, or service by trade name, trademark, manufacturer, or otherwise, does not necessarily constitute or imply its endorsement, recommendation, or favoring by the United Statea Government or any agency, contractor or subcontractor thereof. The views and opinions of authors expressed herein do not necessarily state or reflect those of the United States Government or any agency, contractor or subcontractor thereof.

Printed in the United States of America

Available from

National Technical Information Service

U.S. Department of Commerce

5285 Port Royal Road

Springfield, VA 22161

NTIS price codes:

Printed Copy: A11; Microfiche Copy: A01 


\section{ACKNOWLEDGEMENTS}

In addition to the contributors listed on the title page, there were many other individuals who assisted in the collection of data and preparation of this report. The editors express their gratitude to all these individuals. Two individual efforts however require special acknowledgement. Barbara Cox and Marie De Angelis were the individuals responsible for typing this report. The editors express their thanks and acknowledge their outstanding efforts. 
Internal Distribution:

\begin{tabular}{|c|c|c|c|}
\hline Department & Person & Department & Person \\
\hline $\mathrm{ADD}$ & $\begin{array}{l}\text { S. Musolino } \\
\text { S. Osaki } \\
\text { F. Thornhill }\end{array}$ & $\mathrm{OMC}$ & $\begin{array}{l}\text { B. Breitenstein } \\
\text { M. Sacker }\end{array}$ \\
\hline AGS & $\begin{array}{l}\text { E. Lessard } \\
\text { D. I. Lowenstein } \\
\text { J. Spinner }\end{array}$ & $\mathrm{PE}$ & $\begin{array}{l}\text { M. Bebon } \\
\text { L. Jacobson } \\
\text { J. Medaris } \\
\text { E. Murphy }\end{array}$ \\
\hline BIO & $\begin{array}{l}\text { F. Wm Studier } \\
\text { N. Temple }\end{array}$ & P\&GA & $\begin{array}{l}\text { K. Boehm } \\
\text { J. Laurie } \\
\text { M. Rosen }\end{array}$ \\
\hline BOOSTER & W. Weng & PHY & $\begin{array}{l}\text { P. Bond } \\
\text { C. Carlson. }\end{array}$ \\
\hline CHEM & $\begin{array}{l}\text { C. Creutz } \\
\text { N. Sutin }\end{array}$ & & $\begin{array}{ll}\mathrm{J}, & \text { Collins } \\
\text { K. } & \text { Einfeldt } \\
\mathrm{J}, & \text { Throwe }\end{array}$ \\
\hline CS & $\begin{array}{l}\text { A. Jens } \\
\text { N. Satterly } \\
\text { R. Spellman }\end{array}$ & PUBLIC REL. & A. Baittenger \\
\hline DAS & $\begin{array}{l}\text { P. Carr } \\
\text { C. Krishna } \\
\text { P. Michael }\end{array}$ & RD & $\begin{array}{l}\text { M. Brooks } \\
\text { N. Houvener }\end{array}$ \\
\hline & L. Petrakis & $S \& E P$ & $\begin{array}{l}\text { P. Bergh } \\
\text { W. Casey }\end{array}$ \\
\hline DIRECTOR'S & S. Baron & & N. Carter \\
\hline OFFICE & $\begin{array}{l}\text { M. Blume } \\
\text { M. Davis } \\
\text { G. Kinne } \\
\text { H. Grahn } \\
\text { E. Rohrer } \\
\text { N. Samios } \\
\text { M. Schwartz } \\
\text { R. Setlow }\end{array}$ & & $\begin{array}{l}\text { J. Dietz, } \\
\text { L. Emma } \\
\text { C. Flood } \\
\text { M. Haleem } \\
\text { H. Kahnhauser } \\
\text { A. Kuehner } \\
\text { E. Lanning } \\
\text { F. Marotta } \\
\text { B. Peinberton } \\
\text { R. Reciniello }\end{array}$ \\
\hline DNE & $\begin{array}{l}\text { W. Becker } \\
\text { R. Duffey }\end{array}$ & & $\begin{array}{l}\text { C. Weilandics } \\
\text { P. Williams } \\
0 \text { White }\end{array}$ \\
\hline \multirow[t]{2}{*}{ INST } & $\begin{array}{l}\text { V. Radeka } \\
\text { R. Richardson }\end{array}$ & & \\
\hline & & $S \& M$ & M. Guacci \\
\hline MED & $\begin{array}{l}\text { D. Joel } \\
\text { G. Meinken } \\
\text { H. Susskind }\end{array}$ & AUI & J. Hudis \\
\hline NSLS & $\begin{array}{l}\text { K. Batchelor } \\
\text { T. Dickinson } \\
\text { D. McWhan }\end{array}$ & & \\
\hline OER & A. Raphael & & \\
\hline
\end{tabular}


External Distribution:

DOE Distribution:

Office of Environmental Guidance and Compliance (EH-23) - 5 copies

Office of Environmental Audit (EH-24) - 2 copies

Office of NEPA Project Assistance (EH-25) - 2 copies

Chicago Operations Office - 10 copies

Brookhaven Area Office - 10 copies

H. McCammon, Office of Health and Environmental Research - 1 copy

\section{EPA Distribution: (2 copies each)}

P. Giardina, Radiation Safety Program, U.S. EPA Region II

W. Gunther, U. S. EPA, Office of Radiological Programs, Washington, DC

J. Logsdon, U. S. EPA, Office of Radiological Safety Program

New York State:

R. Aldrich, NYS Department of Health (DOH)

P. Barbato, NYS Department of Environmental Conservation (NYSDEC)

R. Becherer, NYSDEC

G. Brezner, NYSDEC

F. Panek, NYSDEC

P. Roth, NYSDEC

\section{Suffolk County:}

D. Moran, Suffolk County Department of Health Services (SCDHS)

J. Pim, SCDHS

P. Ponturo, SCDHS

G. Tarulli, SCDHS

\section{U.S. Congressman:}

G. Hochbrueckner

\section{General Distribution:}

M. Awschalom, Fermilab

W. J. Bair, Pacific Northwest Laboratory

H. Beck, Environmental Measurements Laboratory

D. Bingham, United States Geological Survey

M. Cordaro, Long Island Lighting Company

J. Cossart, Fermi? ab

J. J. Fix, Pacific Northwest Laboratory

E. Gupton, Oak Ridge National Laboratory

E. P. Hardy, Environmental Measurements Laboratory

J. Hunter, Rutgers University

L. Johnson, Los Alamos Scientific Laboratory

L. Koppelman, Nassau-Suffolk Regional Planning Board 


\section{General Distribution: (continued)}

G. L. Lindeken, Lawrence Livermore Laboratory

A. Nelson, Long Island Lighting Company

E. O'Connell, State University of New York, Stony Brook

C. M. Patterson, Savannah River Laboratory

H. W. Patterson, Lawrence Livermore Laboratory

K. R. Price, Pacific Northwest Laboratory

W. Reinig, Savannah River Laboratory

J. D. Sage, Bettis Atomic Power Laboratory

T. H. Schoenberg, Knolls Atomic Power Laboratory

J. Sedlet, Argonne National Laboratory

C. W. Sill, Idaho National Engineering Laboratory

J. Soldat, Pacific Northwest Laboratory

NOTE: Additional reports are distributed to interested parties responding to the BNL press release that announces the issuance of the report. 
TABLE OF CONTENTS

1.0

INTRODUCTJON . . . . . . . . . . . . . . . . . . . . . . . 1

1.1

1.2

Site Mission . . . . . . . . . . . . . . . . . . . . . . . . 1

Site Characteristics . . . . . . . . . . . . . . . . 1

1.3

Existing Facilities... . . . . . . . . . . . . . . . . 11

1.4

Programmatic Changes in 1990 . . . . . . . . . . . . . . . . 13

2.0

SUMMARY . . . . . . . . . . . . . . . . . . 15

2.1

Airborne Effluents . . . . . . . . . . . . . . . . . 15

Liquid Effluents . . . . . . . . . . . . . . . . . 15

External Radiation Monitoring . . . . . . . . . . . . . . . 17

Atmospheric Radioactivit:y . . . . . . . . . . . . . . . . . . 17

Radioactivity in Precipitation . . . . . . . . . . . . . . . 18

Soil and Vegetation . . . . . . . . . . . . . . . . . . . . 18

Surface Water . . . . . . . . . . . . . . . . . . . . . . . . 18

Aquatic Biological Survelllance . . . . . . . . . . . . . . . 19

Potable Water Supply . . . . . . . . . . . . . . . . . . . . 19

Ground Water Survelllance . . . . . . . . . . . . . . . 20

Radiological Analyses . . . . . . . . . . . . . . . . . . . . 21

Non-radiological Analyses . . . . . . . . . . . . . . . . . . 22

Off-Site Dose Estimates . . . . . . . . . . . . . . . . . . . 24

Quality Assurance Program . . . . . . . . . . . . . . . . 24

3.0 EFFLUENT EMISSIONS AND ENVIRONMENTAL SURVEILLANCE . . . . . . 25

3.1 Airborne Effluent Emissions . . . . . . . . . . . . . . . . 25

3.1.1 Radioactive Airborne Effluent Emissions.... . . . . . . . 25

3.1.2 Nonradioactive Airborne Effluent Emissions . . . . . . . . . 28

3.2 Liquid Effluents . . . . . . . . . . . . . . . . . 28

3.2 .1 Liquid Waste Management . . . . . . . . . . . . . . . . 28

3.2.2 Sanitary System Effluents . . . . . . . . . . . . . . . . 30

3.2.2.1 Radiological Analyses . . . . . . . . . . . . . . . . . . . 32

3.2.2.2 Non-radiological Analyses. . . . . . . . . . . . . . . 36

3.2.3 Recharge Basins . . . . . . . . . . . . . . . 36

3.2.3.1 Recharge Basins - Radiological Analyses . . . . . . . . . . . 48

3.2.3.2 Recharge Basins - Non-radiological Analyses . . . . . . . . . 48

3.3 Environmental Measurements and Analyses . . . . . . . . . . . 48

3.3.1 External Radiation Monitoring . . . . . . . . . . . . . . . 48

3.3.2 Atmospheric Radioactivity................. . 49

3.3.2.1 Tritium Alalyses . . . . . . . . . . . . . . . . 49

3.3.2.2 Radioactive Particulate . . . . . . . . . . . . . . 52

3.3.3 Radioactivity in Precipitation . . . . . . . . . . . . . . . 53

3.3.4 Radioactivity and Metals in Soil, Grass and Vegetation . . 53

3.3.5 Peconic River Aquatic Surveillance . . . . . . . . . . . . . 53

3.3.5.1 Radiological Analyses . . . . . . . . . . . . . . . . . . . 53

3.3.5.2 Non-radiological Analyses . . . . . . . . . . . . . . . . . 54

3.3.6 Aquatic Biological Surveillance . . . . . . . . . . . . . . . 54

3.3.7 Potable Water and Process Supply Wells . . . . . . . . . . . 57

3.3.7.1 Radiological Analyses . . . . . . . . . . . . . . . . . . 58

3.3.7.2 Non-radiological Analyses . . . . . . . . . . . . . . . . . 58 
3.3.8 Ground Water Surveillance . . . . . . . . . . . . . . . . . 59

3.3.8.1 Radiological Analyses... . . . . . . . . . . . . . . . . . 61

3.3.8.2 Non-radiological Analyses . . . . . . . . . . . . . . . . . . 70

Laboratory Quality Assurance . . . . . . . . . . . . . . . 75

4.0 OFF-SITE DOSE ESTIMATES . . . . . . . . . . . . . . . . . . . 76

4.i Dose Equivalents due to Airborne Effluents... . . . . . . . . 76

4.2 Dose Equivalents due to Liquid Effluents . . . . . . . . . . 76

4.3 Collective (Population) Dose Equivalent . . . . . . . . . . . 79

5.0 REgULATORY AFFAIRS . . . . . . . . . . . . . . . . . . . . . 80

5.1 Brookhaven National Laboratory - Suffolk County Agreement . . 80

5.1.1 Review of Engineering Design Drawings . . . . . . . . . . . . 80

5.1.2 Registration of Toxic Liquid Storage Facilities . . . . . . . 80

5.2

5.3

SPDES Permit Renewal . . . . . . . . . . . . . . . . . . . . 81

Compliance with State Pollution Discharge Elimination System

Discharge Limitations . . . . . . . . . . . . . . . . . . . . 81

5.3.1 Upstream Monitoring of STP Influent and Automated Diversion

5.4 Closure of Landfill . . . . . . . . . . . . . . . . . . . . . .

5.5 National Emission Standards for Hazardous Air Poliutant Authorization Applications . . . . . . . . . . . . . . . . . 84

5.6

5.6 .1

5.6 .2

Audits and Appraisals. . . . . . . . . . . . . . . . . . . . 84

Tiger Team Assessment General . . . . . . . . . . . . . . . . 84

5.6 .3

5.7

5.8

5.9

5.10

5.11

5. 12

5.13

5. 14

6.0

6.1

6.2

6.3

6.4

6.5

6.6

Inspector General . . . . . . . . . . . . . . . . . . . . .

85

EPA Region II 40 CFR 61 Subpart H NESHAPS Compliance Inspec-

tion . . . . . . . . . . . . . . . . . . . . . 86

$0 i 1$ Spills . . . . . . . . . . . . . . . . . . . . . . . . . 86

Review of Eingineering Design Drawings . . . . . . . . . . . . 86

Major Petroleum Facility (MPF) . . . . . . . . . . . . . . 86

Safe Drinking Water Act (SDWA) . . . . . . . . . . . . . . . 87

NEPA Program . . . . . . . . . . . . . . . . . . . . . . . 88

Superfund Amendments and Reauthorization Act (SARA) of 1986.88

Interagency Agreement (IAG) . . . . . . . . . . . . . . . . . 88

Resource Conservation Recovery Act (RCRA) . . . . . . . . . . 89

ENVIRONMENTAL ASSESSMENTS . . . . . . . . . . . . . . . . . . 90

Biomonitoring of the STP Liquid Effluent . . . . . . . . . . 90

Department/Division Safety Assessments . . . . . . . . . . . 90

Photographic Arts Buildings Liquid Effluent Sampling and

Analysis . . . . . . . . . . . . . . . . . . . . . . . . . . 91

CSF Leaching Pit . . . . . . . . . . . . . . . . . . . . . . 92

Discharge of Resin Column Regeneration Water to Recharge Basin

$\mathrm{HT}(006)$. . . . . . . . . . . . . . . . . . . . . 93

Building 830 and Fire House Completion Reports . . . . . . . 94

7.0 SPECIAL PROJECTS . . . . . . . . . . . . . . . . . . . . . 95

7.1 Status of Environmental Upgrades . . . . . . . . . . . . . . . 95

$\begin{array}{ll}7.1 .1 & \text { General Plant Project (GPP) to Upgrade Underground Storage } \\ \text { Tanks. . . . . . . . . . . . . . . . . . . . . . . . . } 95\end{array}$

7.1.2 Closure of Cesspools . . . . . . . . . . . . . . . . . . . . 97 

非

Multimedia Environmental Pollution Assessment (MEPAS) . . . . 99

Off-site Ground Water Contamination . . . . . . . . . . . . . 99

Vandalism of Ground Water Surveillance We11 18-01 . . . . . . 100

7.8

Investigation of Blue Substance in Recharge Basin HS (Outfall

005) . . . . . . . . . . . . . . . . . 100

8.1

8.2

8.3

8.4

8.5

8.6

8.7

8.7 .1

8.7 .2

8.8

8.8 .1

8.8 .2

8.8 .3

8.9

8.10

8.11

8.11 .1

8.12

8.13

8.14

8.15

8.16

8.17

8.17 .1

8.17 .2

8.17 .3

8.17 .4

8.17 .5

8.17 .6

8.17 .7

8.17 .8

8.17 .9

8. 17.10
COMPLIANCE SUMMARY

Ground Water Contamination in Excess of the DWS and 6 NYCRR

Part 703

SPDES Permit . . . . . . . . . . . 102

Radioactive Airborne Effluent Emissions Governed by NESHAPs , 103

State Air Ldws . . . . . . . . . . . . . . . .. . . . . . . . 104

Suffolk County Sanitary Codes . . . . . . . . . . . . . . . 104

Safe Drinking Water Act (SDWA) . . . . . . . . . . . . . . . 106

Toxic Substance Control Act (TSCA) . . . . . . . . . . . 106

TSCA Program at BNL . . . . . . . . . . . . . . . . 106

PCB Consent Order . . . . . . . . . . . . . . . . . . . 106

Resource Ccnservation Recovery Act (RCRA) . . . . . . . . . . 107

Tiger Team Assessment . . . . . . . . . . . . . . . . . . . . 107

90-Day Accumulation Areas ... . . . . . . . . . . . . . . . . 108

RCRA Permits . . . . . . . . . . . . . . . . . . . . . . . 108

Comprehensive Environmental Response, Compensation Liability

Act (CERCLA) . . . . . . . . . . . . . . . . . . 108

Superfund Amendments and Reauthorization Act (SARA) of 1986, 109

National Environmental Policy Act (NEPA) . . . . . . . . . . 109

Envirormental Assessment for the RHIC . . . . . . . . . . . . 110

Federal Insecticide, Fungicide, and Rodenticide Act . . . . . 110

Endangered Species Act . . . . . . . . . . . . . . . . . . . 110

National Historic Preservation Act . . . . . . . . . . . . . 110

Flood Plain Management . . . . . . . . . . . . . . . . . . . 111

Protection of Wetlands . . . . . . . . . . . . . . . . . . . 111

Compliance Issues During First and Second Quarter of 1991 . , 111

SPDES Compliance Issues . . . . . . . . . . . . . . . . . . . 111

NESHAPs Compliance for Radioactive Airborne Emissions . . . . 112

Compliance with NYS Air Laws . . . . . . . . . . . . . . . . 112

SDWA Compliance Issues with SDWA . . . . . . . . . . . . . . 112

TSCA Compliance Issues . . . . . . . . . . . . . . . . . . . 112

RCRA Compliance Issues . . . . . . . . . . . . . . . . . . . . . 112

SARA Compliance Issues . . . . . . . . . . . . . . . . . . . 113

NEPA Compliance . . . . . . . . . . . . . . . . . . . . . . . 113

Status of IAG Activities . . . . . . . . . . . . . . . . . . 113

EPA Multi-media Inspection . . . . . . . . . . . . . . . . . 113 


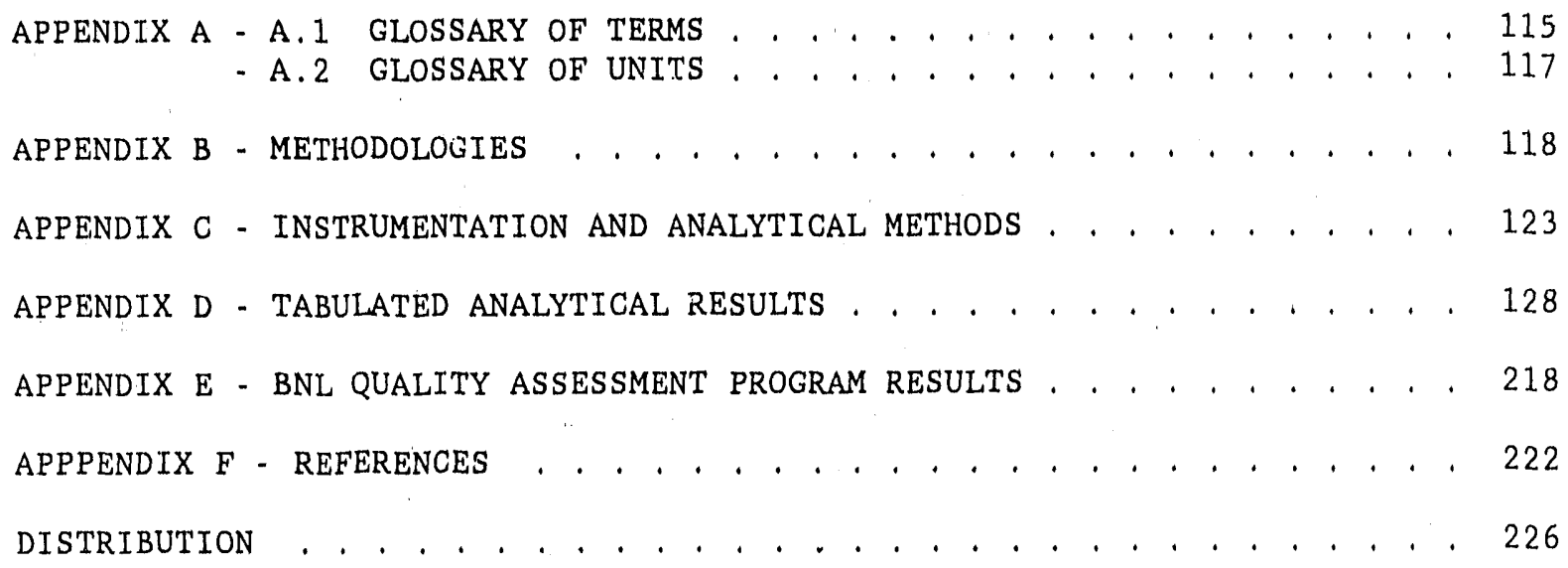


1. Resident Population Within an $80 \mathrm{~km}$ Radius of BNL (1990).....

2. Brookhaven National Laboratory - Local and On-Site

Population Distribution. .....................

3. Major Facilities...........................

4. Annual wind Rose for $1990 \ldots \ldots \ldots \ldots \ldots \ldots$

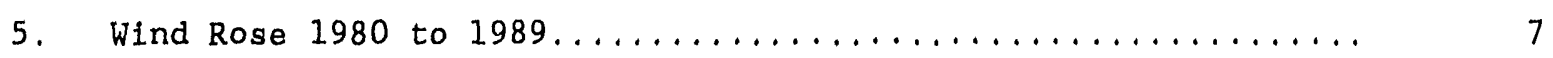

6. Climatology for the BNL Site - Temperature Data - 1990....... 8

7. Precipitation Trend Data for BNL, 1949 to $1990 \ldots \ldots \ldots . \ldots$

8. Climatology for the BNL site Precipitation for $1990 \ldots \ldots \ldots 10$

9. Brookhaven National Laboratory - Effluent Release Points and On-site Environmental Monitoring stations.............. 27

10. Liquid Effluent Systems Brookhaven National Laboratory. . . . . . . 29

11. Sewage Treatment Plant - Sampling Stations............... 31

12. Gross Beta Concentration Data - Sewage Plant and

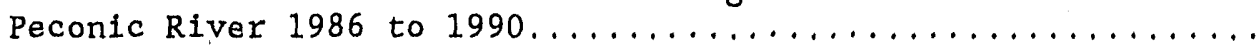

13. Tritium Concentration Data - Sewage Plant and

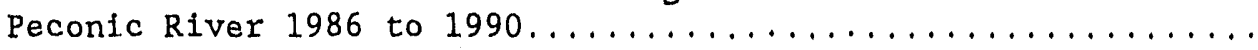

14. Tritium Activity Discharged to the Peconic River

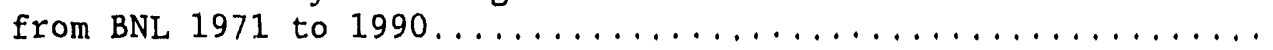

15. Maximum Effluent Concentration of Copper Discharged from

BNL's STP $1986-1990 \ldots \ldots \ldots \ldots \ldots \ldots \ldots \ldots \ldots \ldots \ldots \ldots \ldots$

16. Daily Average Loading of Copper to BNL's STP, $1986-1990 \ldots \ldots$

17. Maximum Effluent Concentration of Iron Discharged by

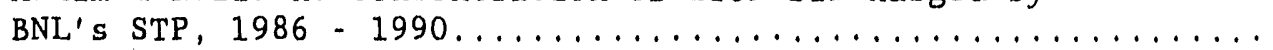

18. Maximum Effluent Concentration of Lead Discharged from

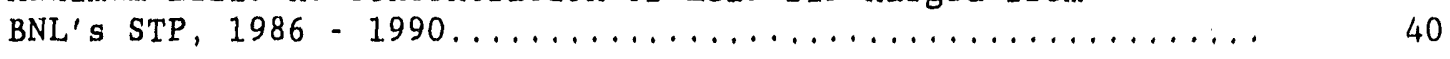

19. Daily Average Loading of Lead to BNL's STP, $1986-1990 \ldots \ldots \ldots$

20. Maximum Effluent Concentration of Silver Discharged from

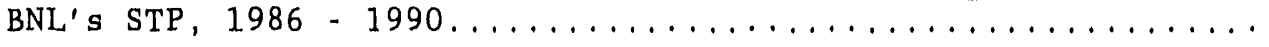


FIGURES cont.

21. Daily Average Loading of Silver to BNI!'s STP, $1986-1990 \ldots \ldots$

22. Maximum Effluent Concentration of Zinc Discharged from

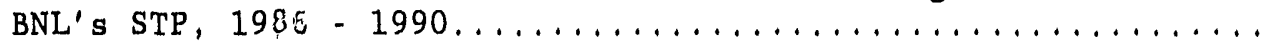

23. Daily Average Loading of Zinc to BNL's STP, $1986-1990 \ldots \ldots \ldots$

24. On-Site: Potable and Supply Wells and Recharge Sumps.........

25. Brookhaven National Laboratory Schematic of Water Use

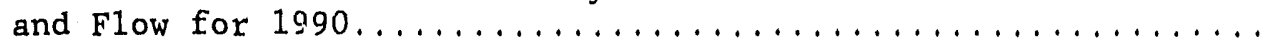

26. Brookhaven Nationa1 Laboratory Location of On-site TLDs........ 50

27. Brookhaven National Laboratory Location of Off-site TLDs.......

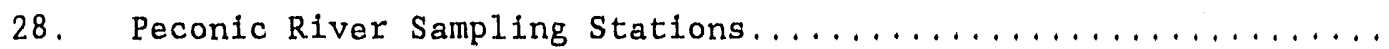

29. Liquid Flow Data - Sewage Plant and Peconic River

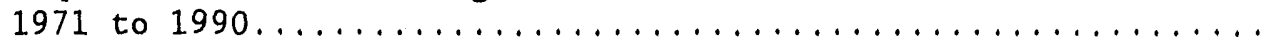

30. Location of Ground Water Monitoring Wells at Brookhaven

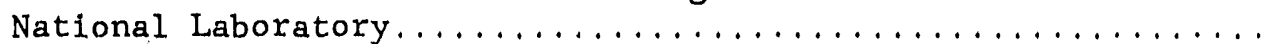

31. Ground Water Monitoring Weils - Peconic River Area........... 63

32. Ground Water Monitoring Wells - AGS Area................... 64

33. Ground Water Monitoring We11s - Central Portion of the Site.... 66

34. Tritium Concentrations - Central Portion of Site........... 67

35. Strontium-90 Concentrations - Central Portion of Site......... 68

36. Ground Water Monitoring Wells - Waste Management and

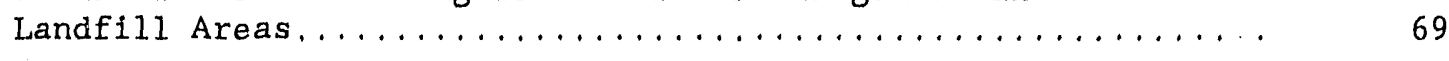

37. Tritium Concentrations - Waste Management and Landfill Areas... 71

38. Strontium-90 Concentrations - Waste Management and

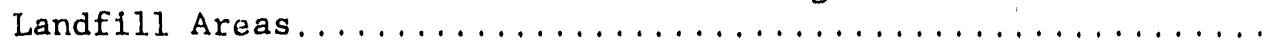

39. Collective Dose - Nuclide Specific 1990 Airborne Emissions..... 77

40. Fraction of Collective Dose by Facility.............. 78 


\section{APPENDIX D TABIES}

1. Resident Population Distribution Within $80 \mathrm{~km}$ of BNL......... 129

2. Wind Rose Joint Frequency Distribution.................. 130

3. Summary of Daily Mean Climatology Data at BNL for 1990....... 131

4. Atmospheric Effluent Release Locations and

Radionuclide Activity........................... 132

5. Noble Gas Releases from the Medical Research Reactor (MRR)

and the Brookhaven Linear Isotope Production Facility (BLIP)..... 133

6. Tritium Releases from 10 -m Stacks.................... 134

7. Airborne Effluent Emissions from Building 750 via the

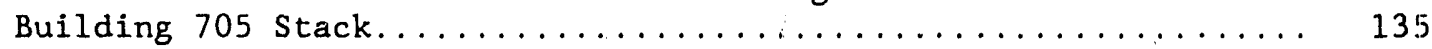

8. Airborne Effluent Releases from Building 301 Acid Off-Gas Stack.. 136

9. Radioactive Airhorne Effluent Emissions from the Non-Acid

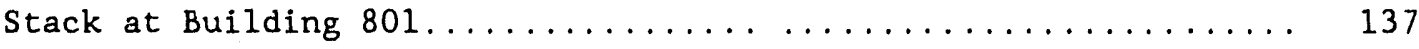

10. Radioactive Effluent Emissions from Building $931 \ldots \ldots \ldots \ldots \ldots$

11. Estimated Radioactivity in Incinerated Material............ 139

12. BNL Environmental Permits....................... 140

13. Sewage Treatment Plant Effluent Gross Alpha, Gross Beta

and Tritium Concentrations.......................... 142

14. Sewage Treatment Plant Effluent Gamma Spectroscopy

and Strontium-90 Concentrations.................... 14.3

15. Sewage Treatment Plant Average Water Quality and

Metals Data.................................... 144

16. SPDES Compliance for Sewage Treatment Plant Effluent......... 145

17. Radioactivity Detected in On-Site Recharge Basin Water

and Run-Off Ponds at the Hazardous Waste Management Area........ 146

18. Water Quality Data in On-Site Recharge Basins............. 147

19. Average Metals Data in On-Site Recharge Basins.............. 148

19A. Chlorocarbon Data in On-site Recharge Basins ............ 149

19B. BTX Data in On-site Recharge Basins ................. 150 
20. External Dose-Equivalent Rates for A11 TLD Locations........... 151

21. Ambient Air Tritium Concentrations at Perimeter and Control Locations.............................. 152

22. Gross Alpha, Gross Beta, and Gamma Emitting Radionuclide Concentrations on Air Particulate Filters from Location 16T2.1..

23. Gross Alpha, Gross Beta, and Gamma Emitting Radionuclide Concentrations on Air Particulate Filters from Location 11T2.1...

24. Gross Alpha, Gross Beta, and Gamma Emitting Radionuclide Concentrations on Air Particulate Filters from Location 6T2.8...

25. Gross Alpha, Gross Beta, and Gamma Emitting Radionuclide Concentrations on Air Particulate Filters from Location 4T2.4 ...

26. Gross Alpha, Gross Beta, and Gamma Emitting Radionuclide Concentrations on Air Particulate Filters from Location S6......

27. Charcoal Filter Data for Station $16 \mathrm{~T} 2.1 \ldots \ldots \ldots \ldots \ldots \ldots \ldots \ldots$

28. Charcoal Filter Data for Station $11 \mathrm{~T} 2.1 \ldots \ldots \ldots \ldots \ldots \ldots \ldots \ldots$

29. Charcoal Filter Data for Station $6 \mathrm{~T} 2.8 \ldots \ldots \ldots \ldots \ldots \ldots \ldots \ldots \ldots \ldots$

30. Charcoal Filter Data for Station $4 \mathrm{~T} 2.4 \ldots \ldots \ldots \ldots \ldots \ldots \ldots \ldots \ldots$

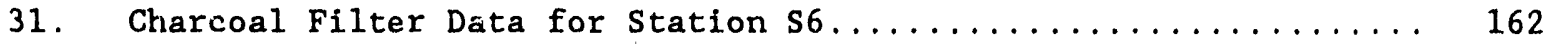

32. Radionuclide Concentrations in Precipitation (Wet and Dry)

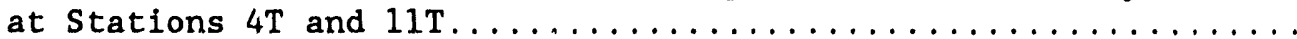

33. Radionuclide Concentrations in Vegetation and Soil

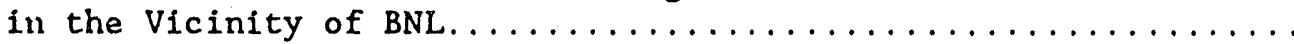

34. Gross Alpha, Gross Beta and Tritium Concentrations in

Peconic River and Carmans River......................

35. Nuclide Specific Concentrations in Peconic River, Carmans River and Small Surface Water Ponds............... 166

36. Peconic River Water Quality Data.................. 167

37. Peconic River Metals Data.......................... 168 
38. Water Quality Parameters for Surface Water Samples

Collected Along the Peconic and Carmans River.............. 169

39. Radionuclide Concentrations in Fish................... 170

40. On-Site Potable and Cooling Water Radionuclide

Concentration Data.............................. 171

41. Gross Alpha, Gross Beta, and Tritium Concentrations in Potable Water and Distilled Water from Building 535B.............. 172

42. Potable Water and Process Supply Wells, Wnter Quality Data...... 173

43. Potable Water and Process Supply We1ls, Average Metals Data..... 174

44. Potable Water Wells, Average Halogenated Organic Compound Data. . 175

45. Potable Water Wells, Average Non-Halogenated Organic

Compound Data.................................. 177

46. Potable Water and Supply Wells, Chlorocarbon Data............. 178

47. Potable Water and Supply Wells, BTX Data................. 179

48. Monitoring Well Identification Cross Reference............ 180

49. Radionuclide Concentrations in Field Blank Samples............ 181

50. Radionuclide Concentrations in Gxound Water at the Upland

Recharge Meadow Marsh Area, the Area Adjacent to the

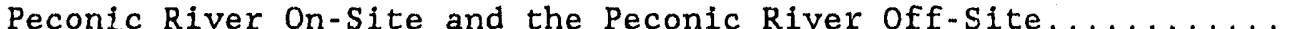

51. Radionuclide Concentrations in off-Site Potable Water......... 183

52. Radionuclide Concentrations in Ground Water - Northeast

Sector, West Sector and South Boundary of the BNL Site......... 184

53. Radionuclide Concentrations in Ground Water within the

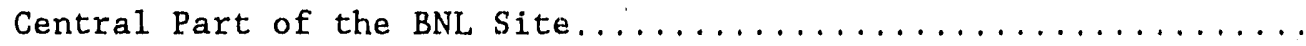

54. Radionuclide Concentrations in Ground Water in the Vicinity of the Ashfill, Current Landfill and Former Landfil1..........

55. Radionuclide Concentrations in Ground Water in the Vicinity of the Hazardous Waste Management Area...................

56. Peconic River Areas and Upland Recharge Meadow Marsh Area Ground Water Surveillance Wells, Water Quality Data........... 
APPENDIX D TABLES cont.

57. Peconic River Areas and Upland Recharge Meadow Marsh Area

Ground Water Surveillance Wells, Average Metals Data...........

58. Peconic River Areas and Upland Recharge Meadow Marsh /.1ea

Ground Water Survelllance Wells, Chlorocarbon Data............

59. Peconic River Areas and Upland Recharge Meadow Marsh Area

Ground Water Survelllance Wells, BTX Data................

60. Landfill Areas and Ash Repository Ground Water Surveillance

We11s, Water Quality Data.......................

61. Landfill Areas and Ash Repository Ground Water Surveillance

Wells, Average Metals Data......................

62. Landfill Areas Ground Water Surveillance Wells,

Chlorocarbon Data...........................

63. Landfill Areas Ground Water Surveillance Wells, BTX Data........ 194

64. Hazardous Waste Management (HWM) Area and Spray Aeration

Project Ground Watex Surveillance Wells, Water Quality Data.....

65. Hazardous Waste Management (HWM) Area and Spray Aeration

Profect Ground Water Surveillance Wells Average Metals Data.....

66. Hazardous Waste Management (HWM) Area and Spray Aeration

Project Ground Water Surveillance Wells, Chlorocarbon Data......

67. Hazardous Waste Management (HWM) Area and Spray Aeration

Project Ground Water Surveillance Wells, BTX Data...........

68. Major Petroleum Facility and Central Steam Facility

Ground Water Surveillance Wells, Water Quality Data...........

69. Major Petroleum Facility and Central Steam Facility

Ground Water Surveillance Wells Average, Metals Data...........

70. Major Petroleum Facility and Central Steam Facility

Ground Water Surveillance Wells, Chlorocarbon Data............

71. Major Petroleum Facility and Central Steam Facility

Ground Water Surveillance Wells, BTX Data.................

72 Miscellaneous Areas of the BNL Site Ground Water

Surveillance Wells, Water Quality Data.................

73. Miscellaneous Areas of the BNL Site Ground Water

Surveillance Wells, Average Metals Data................. 
APPENDIX D TABLES cont.

74. Miscellaneous Areas of the BNL Site Ground Water

Surveillance Wells, Chlorocarbon Data.................

75. Miscellaneous Areas of the BNL Site Ground Water

Surveillance Wells, BTX Data......................... 206

76. Northeast Sector, West Sector, and South Boundary Areas

Ground Water Surveillance Wells, Water Quality Data...........

77. Northeast Sector, West Sector, and South Boundary Areas

Ground Water Surveillance Wells, Average Metals Data........... 208

78. Northeast Sector, West Sector, and South Boundary Areas

Ground Water Surveillance Wells, Chlorocarbon Data............

79. Northeast Sector, West Sector, and South Boundary Areas

Ground Water Surveillance Wells, BTX Data..................

80. Tritium Committed Effective Dose Equivalent at the

Site Boundary Monitoring Stations...................

81. Site Boundary Tritium Committed Effective Dose Equivalent

Calculated and Measured Values....................

82. Externa1 Exposure Rates at the Site from Argon-41 and Oxygen....

83. Collective Dose - BNL 1990 Airborne Emissions.............

84. Collective and Maximum Individual Committed Effective Dose

Equivalent (CEDE) from the Water Pathway ................

85. Collective Dose from All Pathways................... 


\subsection{INTRODUCTION}

\subsection{Site Mission}

Brookhaven National Laboratory (BNL) is managed by Associated Universities Inc. (AUI), under Department of Energy (DOE) Contract No. DE-AC02-76CH00016. AUI was formed in 1946 by a group of nine universities whose purpose was to create and manage a laboratory in the Northeast in order to advance scientific research in areas of interest to universities, industry, and government. On January 31 , 1947, the contract for BNL was approved by the Manhattan District of the Army Corp of Engineers and BNL was established on the former Camp Upton Army camp.

Brookhaven carries out basic and applied research in the following fields: high-energy nuclear and solid state physics; fundamental material and structure properties and the interactions of matter; nuclear medicine, biomedical and environmental sciences; and selected energy technologies. In conducting these research activities, it is Laboratory policy to protect the health and safety of employees and the public, and to minimize the impact of BNL operations on the environment.

\subsection{Site Characteristics}

Brookhaven National Laboratory is a multidisciplinary scientific research center located close to the geographical center of Suffolk County on Long Island, about $97 \mathrm{~km}$ east of New York City. Its location with regard to the metropolitan area and local communities are shown in Figures 1 and 2 , respectively. Abcut 1.40 million persons reside in Suffolk County ${ }^{1}$ and about 0.43 million persons reside in Brookhaven Township, within which the Laboratory is situated. Approximately eight thousand persons reside within a half kilometer of the Laboratory boundary. The distribution of the resident population within $80 \mathrm{~km}$ of the BNL site is shown in Figure 1 and Appendix D, Table 1. The population distribution within $0.5 \mathrm{~km}$ of the BNL site is shown in Figure 2. Although much of the land area within a $16 \mathrm{~km}$ radius remains either forested or cultivated, there has been continuing residential and commercial development near the Laboratory during recent years.

The Laboratory site is shown in Figure 3 . It consists of 21.3 square kilometers $(2,130$ hectares [ha]), most of which is wooded, except for a developed area of about 6.7 square kilometers $(670 \mathrm{ha})$. The site terrain is gently rolling, with elevations varying between 36.6 and $13.3 \mathrm{~m}$ above sea level. The land lies on the western rim of the sha?low Peconic River water shed. The marshy areas in the north and eastern sections of the site are a portion of the Peconic River headwaters. The Peconic River both recharges and receives water from the ground water aquifer depending on the hydrogeological potential. In times of drought the river water typically recharges to ground water while in times of normal to above normal precipitation, the river receives water from the aquifer. This area had been essentially dry from 1984 until the spring of 1989. Consequently, liquid effluents from the BNL Sewage Treatment Plant (STP) constituted the principle source of water in the tributary's river bed diaring the first three months of 1989 but recharged to ground water prior to leaving the site boundary. Beginning in the second quarter of 1989 and continuing through 


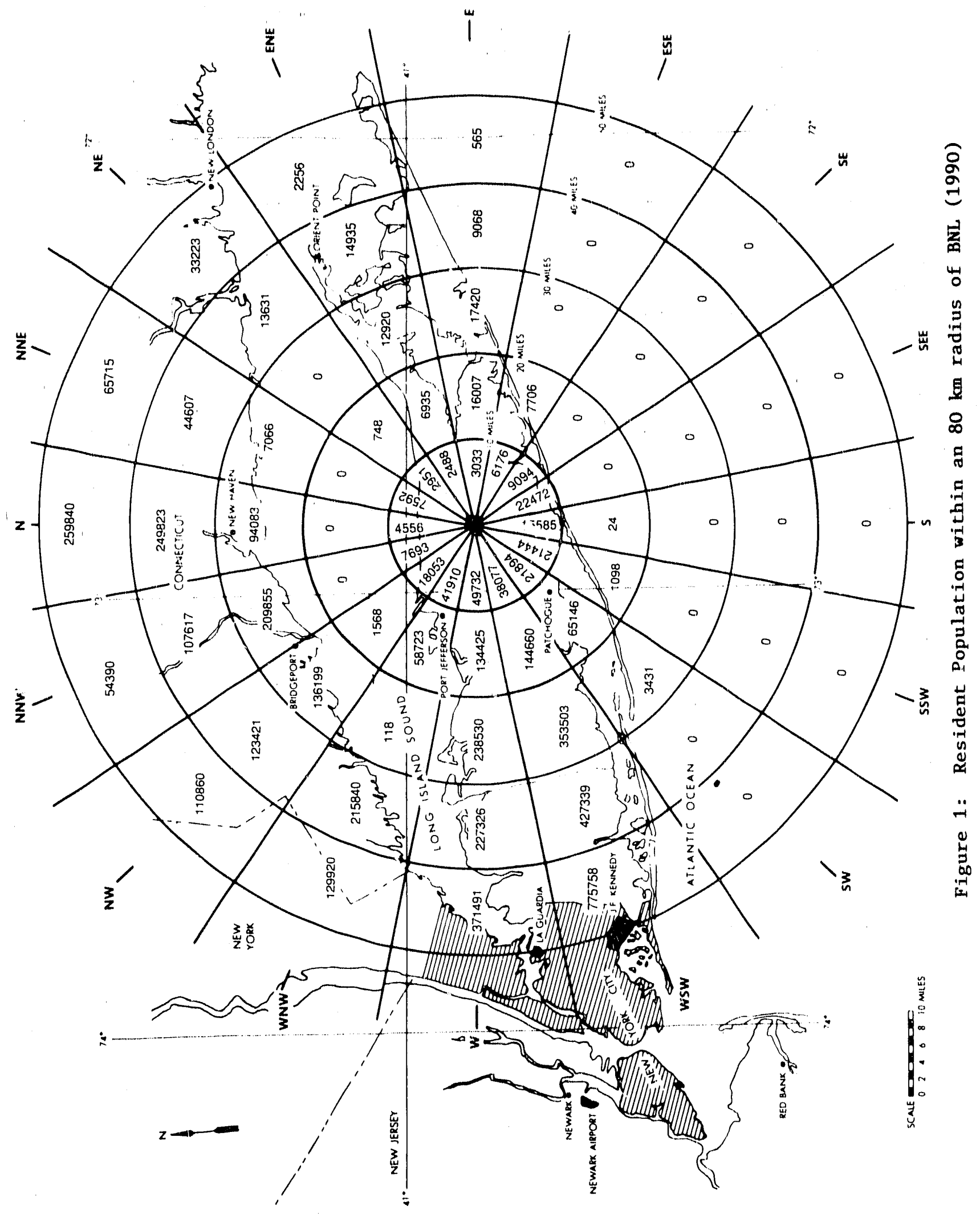


BROOKHAVEN NATIONAL LABORATORY

LOCAL AND ON-SITE POPULATION DISTRIBUTION

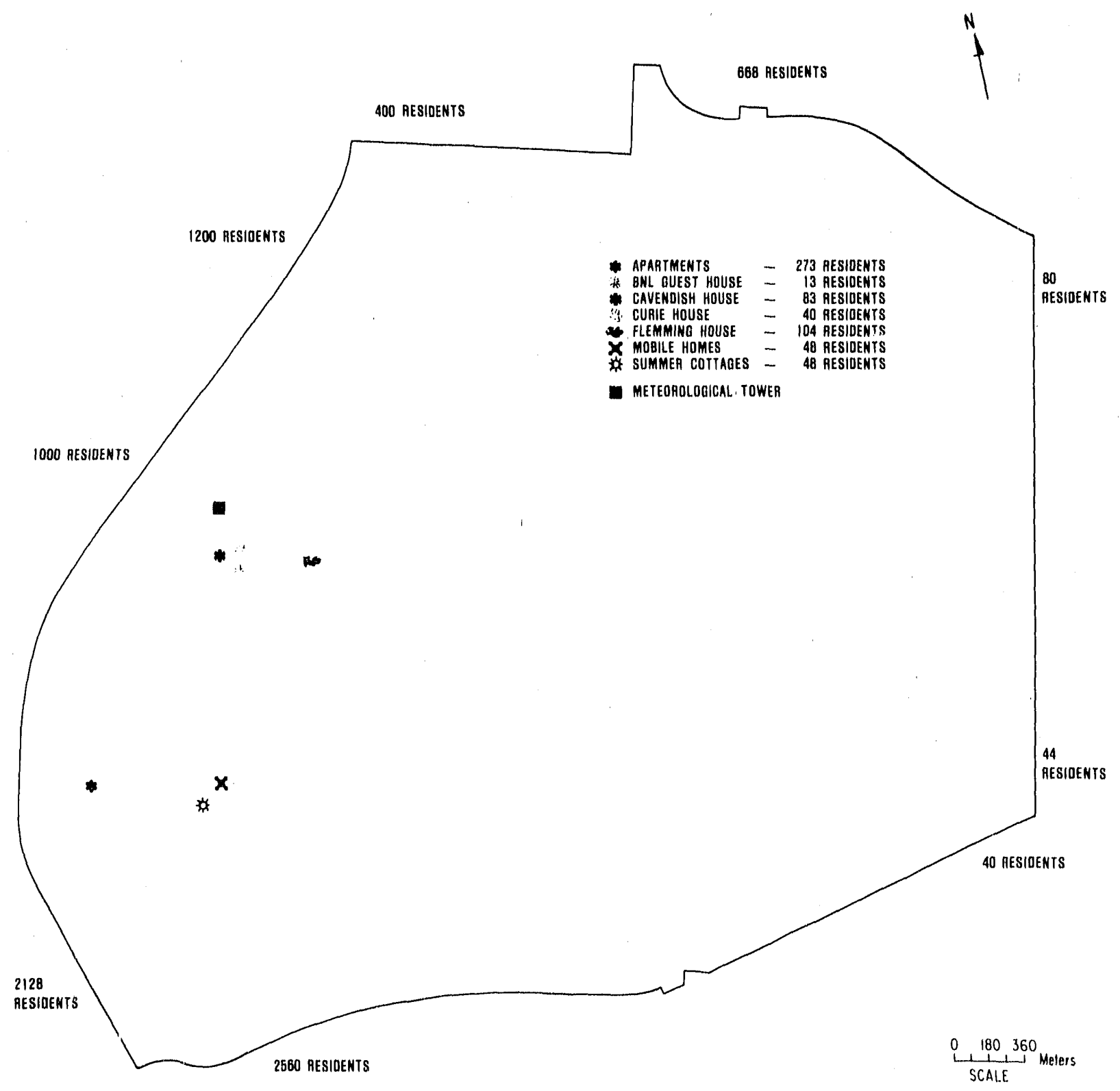

Figure 2: Brookhaven National Laboratory Local and On-Site Population Distribution 


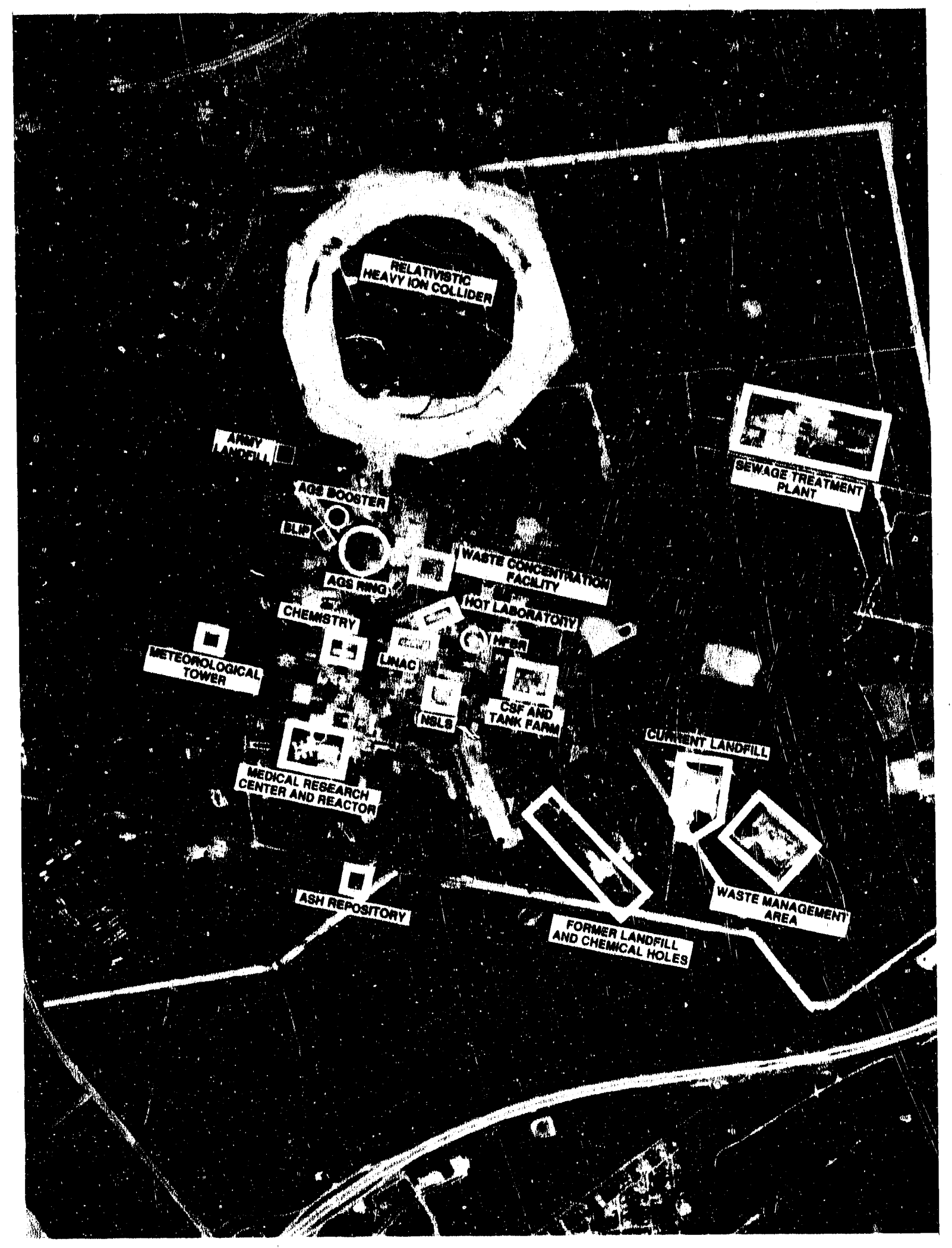

Figure 3: Major Facilities 
1990, heavy rains produced flow upstream of the BNL Chlorine House (Location EA) which provided sufficient additional volume to produce flow off-site. In 1990, an estimated 0.8 intlifion 1 iters per day of water was added to the headwaters of the Peconic from ground water discharge.

The Laboratory uses approximately 16.7 million liters of ground water per day to meet potable water plus heating and cooling requirements. Approximately $41 \%$ of the total pumpage was returned to the aquifer through on-site recharge basins. About $1.5 \%$ is discharged into the Peconic River Bed. Human consunption utilizes $2 \%$ of the total pumpage while evaporation (cooling tower and wind losses) and cesspool plus line losses account for $31 \%$ and $10 \%$, respectively.

In terms of meteorology, the Laboratory can be characterized, like most eastern seaboard areas, as a well-ventllated site. The prevaling ground level winds are from the southwest during the sumner, from the northwest during the winter, and about equally from these two directions during the spring and fall, ${ }^{2,3}$ The 1990 annual wind rose for BNL is presented in. Figure 4. The ten year average wind rose (1980 to 1989) for the BNL site is presented in Figure 5. The foint frequency distribution for the poriod 1980 to 1990 is presented in Appendix $D$, Table 2. The average temperature in 1990 was $11.5^{\circ} \mathrm{C}$ and the range was $-17.6^{\circ} \mathrm{C}$ to $33.3^{\circ} \mathrm{C}$. Monthly minimum, maximum, and average temperature data are presented in Appendix D, Table 3 and shown graphically in Figure 6.

Studies of Long Island hydrology and geology ${ }^{4-7}$ in the vicinity of the Laboratory indicate that the uppermost pleistocene deposits, which are between 31 - $61 \mathrm{~m}$ thick, are generally sandy and highly permeable. Water penetrates these deposits readily and there is little direct run-off into surface streams, except during periods of intense precipitation. The total precipitation for 1990 was $135 \mathrm{~cm}$, which is about $12 \mathrm{~cm}$ above the 40 year annual average. The historic and 1990 monthly precipitation data are presented in Figure 7 and 8 , respective$1 y$. The monthly and annual precipitation data are also presented in Appendix $D$, Table 3. On the average, about half of the annual precipitation is lost to the atmosphere through evapotranspiration and the other half percolates through the soll to recharge ground water.

Ground water flow in the vicinity of BNL is controlled by many factors. The main ground water divide lies 2 to 8 kilometers south of Long Island Sound parallel to the Sound. East of BNL is a secondary ground water divide that defines the southern boundary of the area contributing ground water to the Peconic River. The exact location of the triple-point intersection of these two divides is not known and may be under BNL. South of these divides the ground water moves southward to Great South Bay and to Moriches streams. In general, the ground water from the area between the two branches of the divide moves out eastward to the Peconic River. North of the divide ground water moves northward to Long Island Sound. Pressure of a higher water table to the west of the BNL area generally inhibits movement towards the west. Variability in the direction of flow on the BNL site is a function of the hydraulic potential and is further complicated by the presence of clay deposits that accumulate perched water at several places plus the pumping/recharge of ground water that are part of BNL daily operations. 


\section{Annual hiind Rose for 1990}

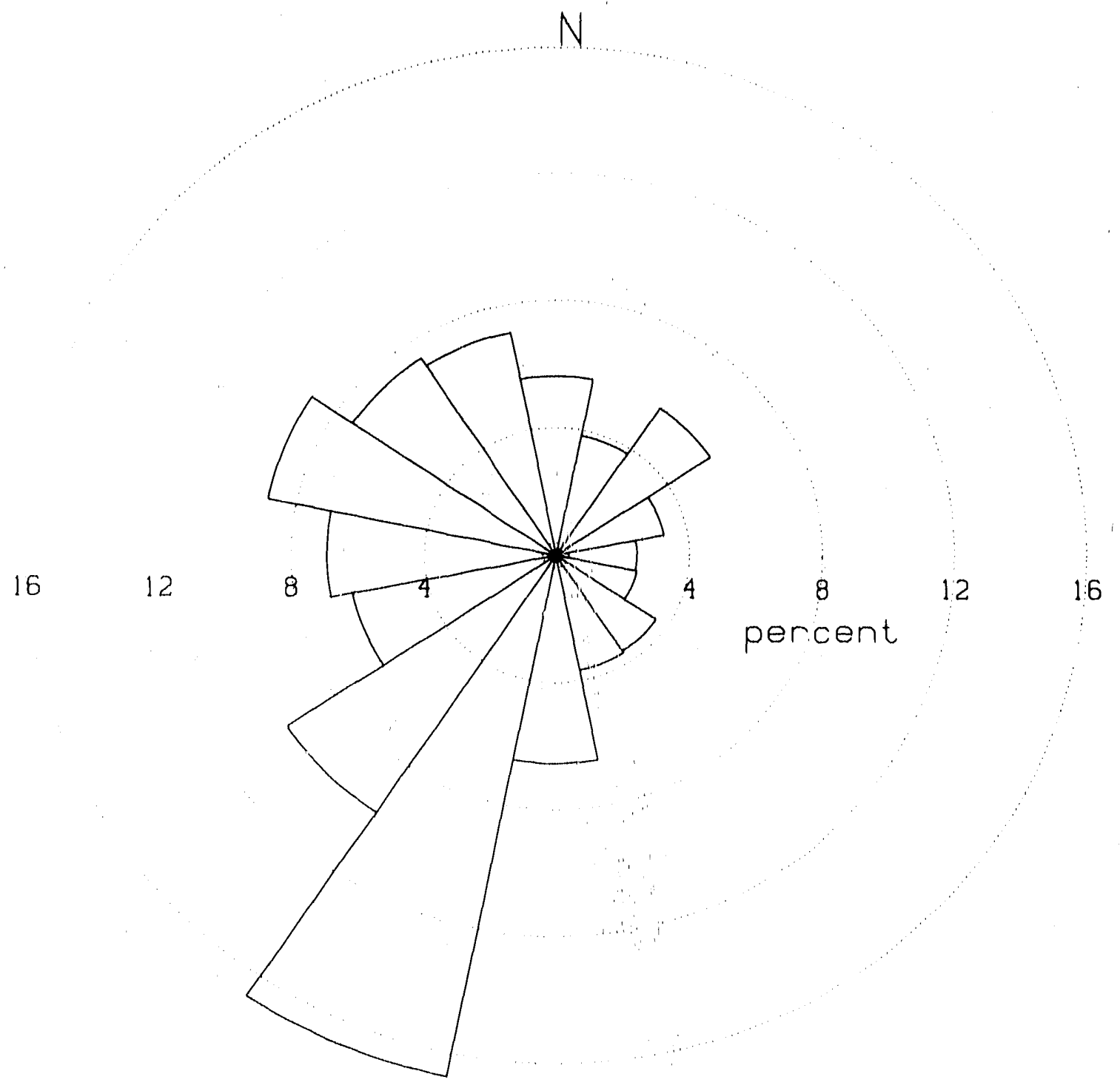

Figure 4: Annual Wind Rose for 1990 


\section{Wind Rose for 1980-1989}

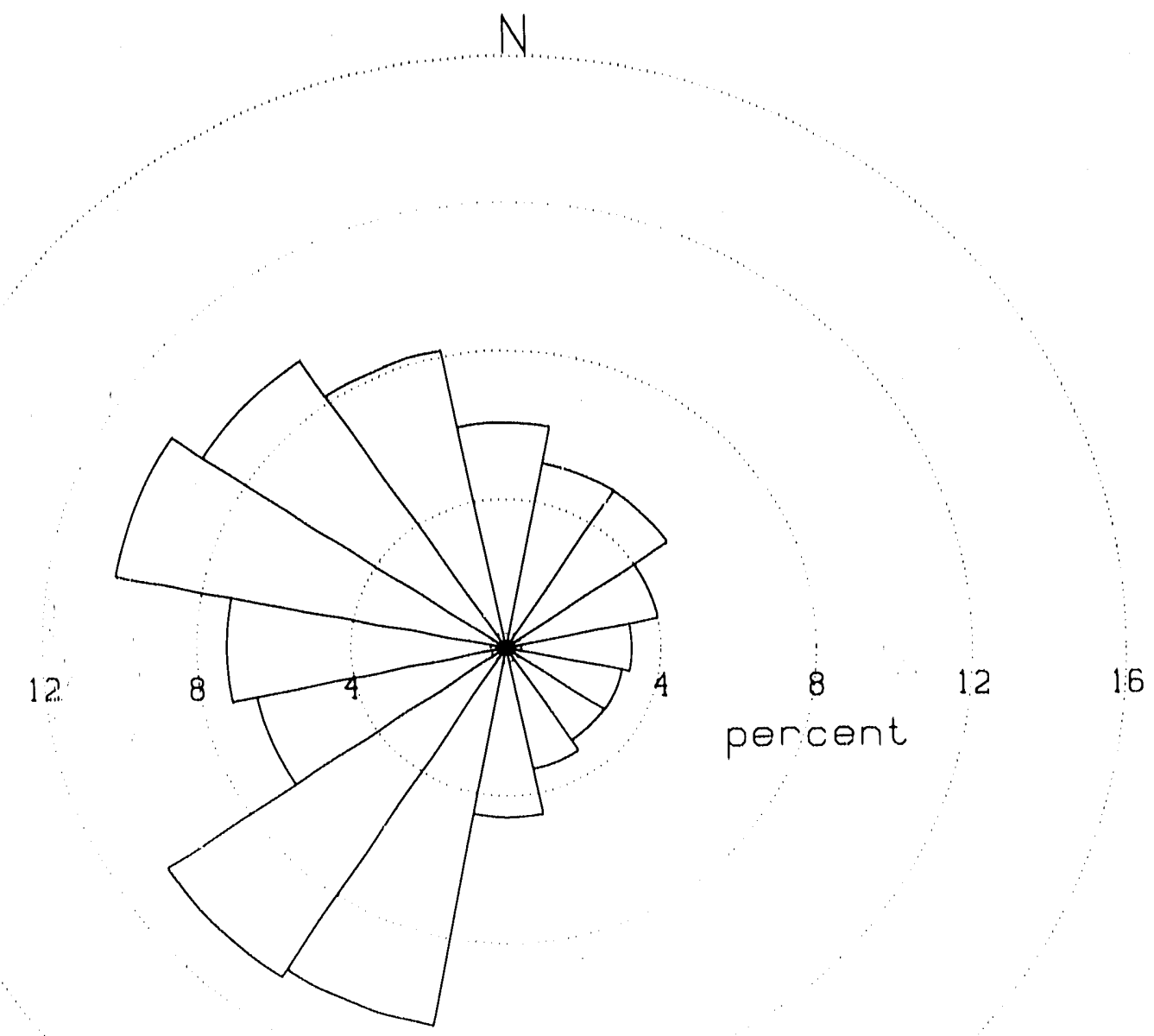

Figure 5: Wind Rose 1980 to 1989 


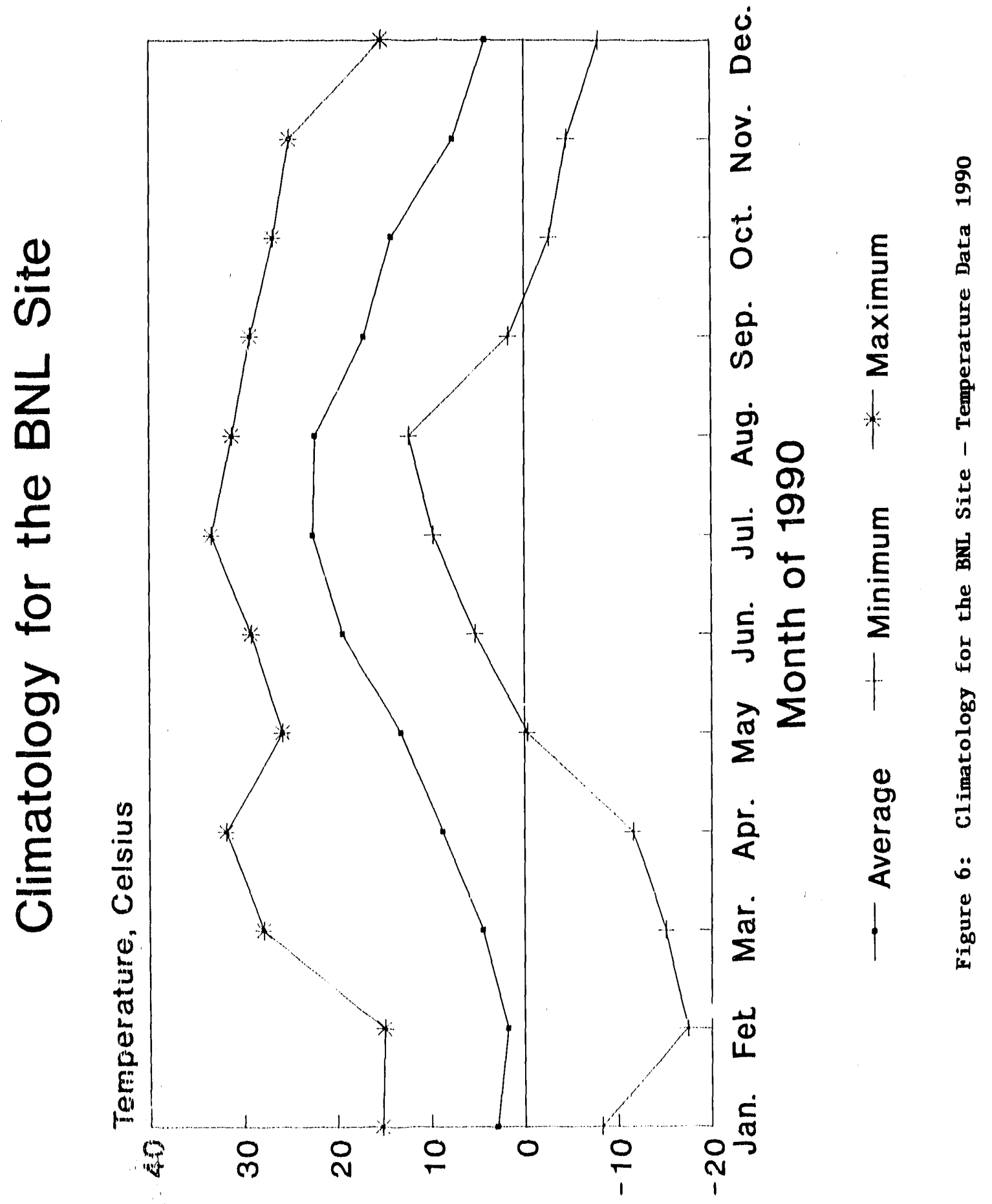




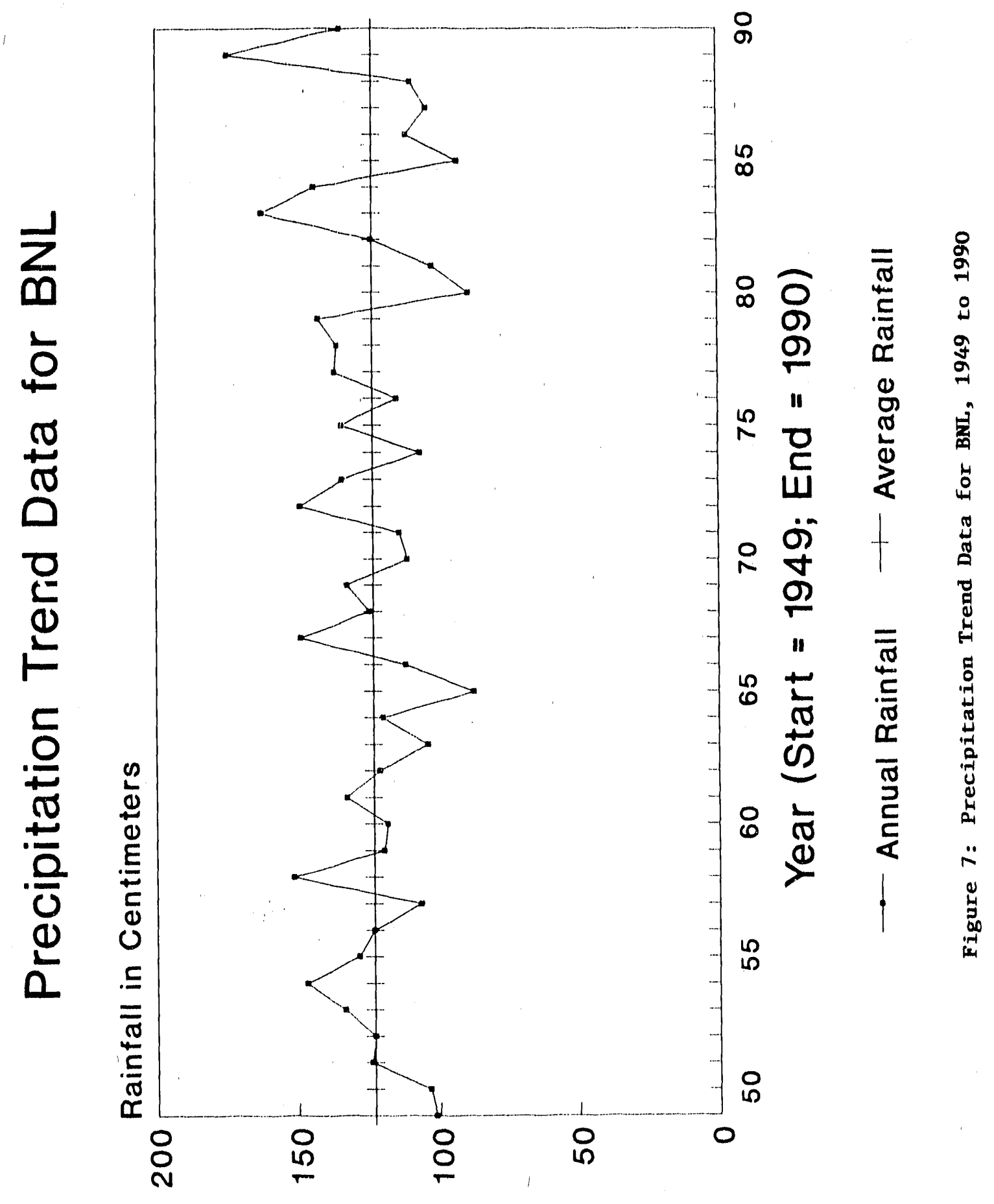




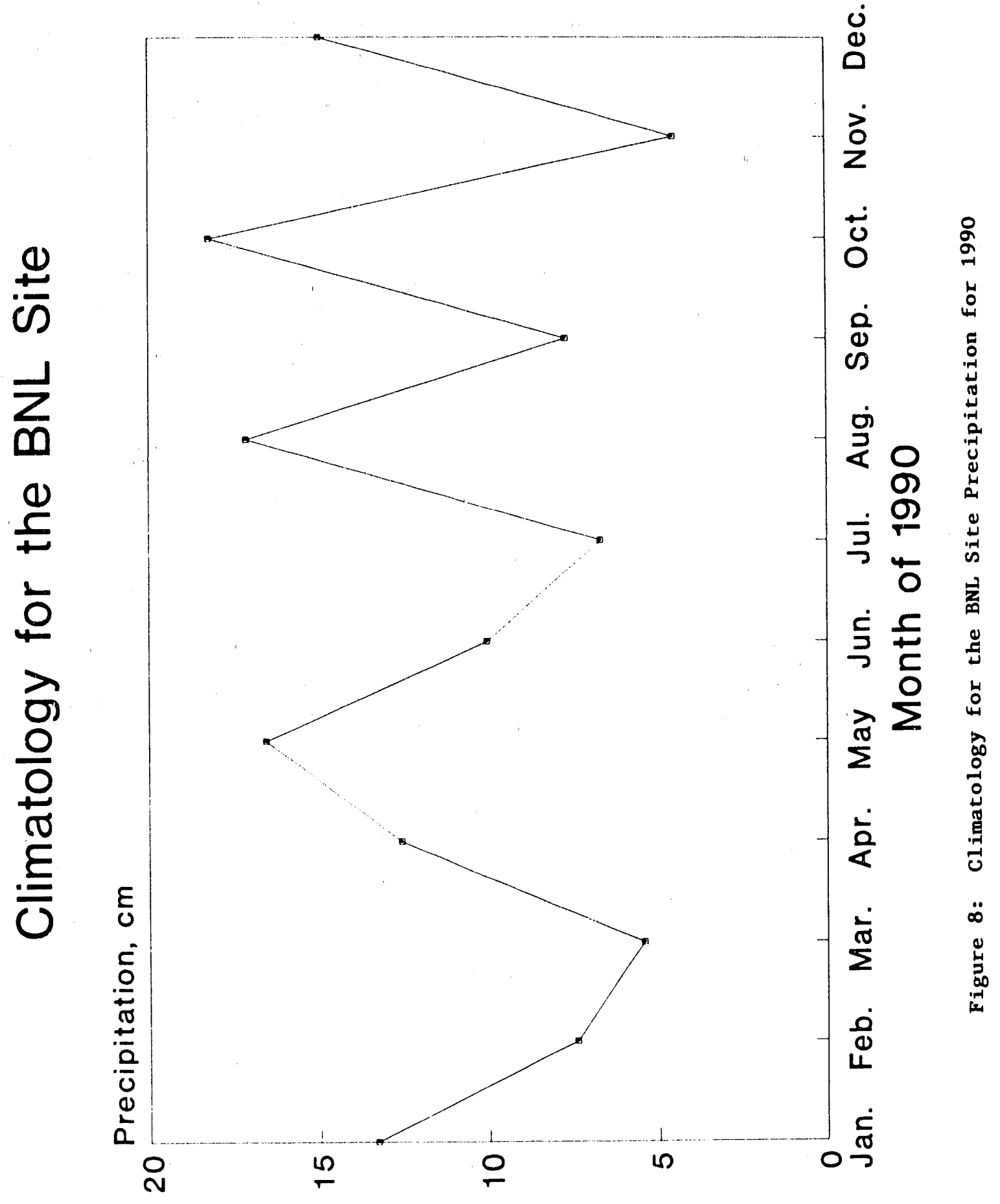


In general, ground water in the northeast and northwest sections of the site flows towards the Peconic River. On the western portion of the site, ground water flow tends to be towards the south while along the southern and southeastern sections of the site the ground water flow tends to be towards the south to southeast. In all areas of the site, horizontal ground water velocity is estimated to range from 30 to $45 \mathrm{~cm} / \mathrm{d} .^{7}$ The site occupied by BNL has been identified by the Long Island Regional Planning Board ${ }^{8}$ and Suffolk County as being over a deep recharge zone for Long Island. This implies that precipitation and surface water which recharges within this zone has the potential to replenish the lower aquifer systems (Magothy and/or Lloyds) which exist below the Upper Glacial Aquifer. The extent to which the BNL site contributes to deep flow recharge is currently under evaluation. However, it is estimated that up to two thirds of the recharge from rainfall moves into the deeper aquifers and that their recharge represents ten percent of the total recharge to the ground water system. If left unimpeded, these lower aquifers discharge to the Atlantic Ocean.

\subsection{Existing Facilities}

A wide variety of scientific programs are conducted at Brookhaven, including research and development in the following areas:

1. The fundamental structure and properties of matter;

2. The interactions of radiation, particles, and atoms with other atoms and molecules;

3. The physical, chemical, and biological effects of radiation, and of other materials;

4. The production of special radionuclides and their medical applications;

5. Energy and nuclear related technology; and

6. The assessment of energy sources, transmission and uses, including their environmental and health effects.

The major scientific facilities which are operated at the Laboratory to carry out the above programs are described below:

1. The High Flux Beam Reactor (HFBR) is fueled with enriched uranium, moderated and cooled by heavy water. In the past, this facility operated at a routine power level ranging from 40 to $60 \mathrm{MW}$ thermal.

2. The Medical Research Reactor (MRR), an integral part of the Medical Research Center (MRC), is fueled with enriched uranium, moderated and cooled by light water, and is operated intermittently at power levels up to $3 \mathrm{MW}$ thermal. 
3. The Alternating Gradient Synchrotron (AGS) is used for high energy physics research and accelerates protons to energies up to $30 \mathrm{GeV}$ and heavy ion beams to $15 \mathrm{GeV} / \mathrm{amu}$.

4. The $200 \mathrm{MeV}$ Linear Accelerator (LINAC) serves as a proton injector for the AGS and also supplies a continuous beam of protons for radionuclide production by spallation reactions in the Brookhaven LINAC Isotope Production Facility (BLIP).

5. The Tandem Van de Graaff, Vertical Accelerator, Cyclotron, and research Van de Graaff are used in medium energy physics investigations, as well as for special nuclide production. The heavy ions from the Tandem Van de Graaffs can also be injected into the AGS for use in physics experiments.

6. The National Synchrotron Light Source (NSLS) utilizes a linear accelerator and booster synchrotron as an injection system for two electron storage rings which operate at energies of $750 \mathrm{MeV}$ vacuum ultraviolet (VUV) and $2.5 \mathrm{GeV}$ (x-ray). The synchrotron radiation produced by the stored electrons is used for VUV spectroscopy and for $x$-ray diffraction studies.

7. The Heavy Ion Transfer tunnel connects the coupled Tandem Van de Graaffs and the AGS. The interconnection of these two facilities permits the injection of intermediate mass ions into the AGS where the ions can be accelerated to an energy of $15 \mathrm{GeV} / \mathrm{amu}$. These ions are then extracted and sent to the AGS experimental area for physics research.

8. The Radiation Effects Facility (REF) is being used for proton radiation damage studies on aerospace and satellite components. The REF utilizes the $200 \mathrm{MeV}$ negative hydrogen ion beam produced at the LINAC injector to the AGS.

9. The Neutral Beam Test Facility (NBTF) receives the $200 \mathrm{MeV}$ negative hydrogen beam generated by the LINAC and neutralizes the beam to provide a neutral proton source for use in physics experiments. The facility will be used to study the effect of this type of radiation on aerospace, satellite, and biological targets.

10. The AGS Booster, currently under construction, is a circular accelerator with a circumference of 200 meters that will receive either a proton beam from the LINAC or heavy ions from the Tandem Van de Graaff. The Booster will accelerate proton particles and heavy ions prior to injection into the AGS ring.

Additional programs involving irradiations and/or the use of radionuclides for scientific investigations are carried out at other Laboratory facilities including those of the MRC, the Biology Department, the Chemistry Department, and the Department of Applied Sciences (DAS). Special purpose radionuclides are developed and processed for general use under the joint auspices of the DAS and the Medical Department. 


\subsection{Programmatic Changes in 1990}

There were several modifications to the Site Environmental Monitoring Program in 1990. In general, these changes were designed to either enhance the environmental surveillance program, improve data quality or address regulatory compiliance needs. Six changes were made at the beginning of 1990.

First, in an effort to locate all environmental monitoring locations on the BNL site mapping system, ground water surveillance wells were re-identified by the three digit sector number of the BNL site map in which they appear and a two digit sequence number. The resulting five digit code (Example 098-05) replaced all former well identifiers (Example MW13). This facilitated generation of a single map which located all ground water monitoring wells and provided the capability to produce a limitless variety of localized maps using CADCAM computerized technology. The second change provided a different method for assaying air particulate filters. Prior to 1990, ambient air particulate filters for the entire site were composited monthly and analyzed for gamma emitting radionuclides. Beginning in January, each sample location was analyzed weekly. The change provided location specific radionuclide concentration levels but did increase the system limits of detection. This change was made as a result of the 1989 Dames and Moore audit of the environmental monitoring program. The third change was the inclusion of ponded water near the Hazardous Waste Management Facility (HWMF) and the Current Landfill on the routine sampling schedule. Addition of these two locations to the routine sampling program was made in an effort to allocate time to obtain samples from this area where water is present on an intermittent basis.

The fourth change was the use of the CAP88 or AIRDOS-PC computer models for evaluation of impacts from radiological airborne effluents. The implementation of this evaluation system ended the use of the site specific BNL Gustiness method to model dispersion. This change was made to facilitate compliance with $40 \mathrm{CFR}$ 61 Subpart $\mathrm{H}$ requirements. Down draft from the Building 705 stack was also included in airborne effluent assessment. The addition of routine analysis of water samples from the BNL recharge basins for volatile organic compounds (VOCs) to the analysis schedule was the fifth change. Finally, the certification for the Safety and Environmental Protection (S\&EP) Division's Analytical Chemistry Laboratory for purgeable organic compounds analyses was changed from potable to nonpotable. While this change does not affect data quality or instrument detection limits, it did result in a minor change in the analytes reported.

In the second quarter of 1990 , the largest change to the program occurred when ground water sampling at the 0ld Landfill, Current Landfill, and Hazardous Waste Management areas of the site was suspended from April to the early part of June. The suspension of the program was instituted in a effort to address issues raised by the DOE Tiger Team. During this period, Occupational Safety anc Health Administration (OSHA) 1910.120 training occurred, a sampling health and safety plan was written, ground water well identification problems associated with conversion to the new grid identification system were investigated and sampling protocols were developed or reviewed. Although sampling resumed in June, most of the second quarter ground water schedule could not be completed due to time constraints and accessibility of sampling locations in June. 
In the third quarter of 1990, monthly grab sampling of water entering the Peconic River from the BNL (STP) commenced in response to a New York State Department of Environmental Conservation (NYSDEC) State Pollution Discharge Elimination System (SPDES) Notice of Violation at this location. A grab sample collected by NYSDEC in March, 1990 identified the presence of organic compounds in the BNL effluent. Routine monitoring was implemented to verify the presence of organic compound in the STP effluent over a protracted period of time. During this quarter the sampling heights of thermoluninescent dosimeters (TLDs) and ambient tritium monitors was changed. Prior to this time, both sampling media were located at approximately three feet from the ground elevation. In September, TLDs were all moved to one meter off the ground while ambient air sainpling stations had their intakes raised to approximately two meters. Finally, a quality assurance (QA) audit of BNL's strontium-90 contractor laboratory was performed in this quarter. The audit identified deviances from protocols and good laboratory practices that raised questions regarding the quality of resi.1 ts being generated. Arbitration between the company and BNL falled to resolve these concerns. During the period of negotiation, no samples were shipped for analysis. The contract was terminated in the fourth quarter. A contract for analysis of effluent samples was issued to another laboratory late in the fourth quarter while new contract specifications were being developed. The second laboratory analyzed the samples in a manner that also falled QA considerations. The remainder of the 1990 samples that require strontium-90 analysis were not analyzed and were held until a new contract could be awarded through the normal contract awards process. Fourth quarter strontium-90 data will be included in the 1991 Site Environmental Report (SER). 


\subsection{SUMMARY}

The Envirormental Monitoring (EM) Program is conducted by the Environmental Protection (EP) Section of the S\&EP Division to determine whether operation of BNL facilities have met the applicable environmental standards and effluent control requirements. This program includes monitoring for both radiological and non-radiological parameters. This report summarizes the data for the external radiation levels; radioactivity in air, rain, potable water, surface water, ground water, soil, vegetation, and aquatic biota; water quality, metals, organics and petroleum products in ground water, surface water, and potable water.

Analytical results are reviewed by the S\&EP staff and when required by perinit conditions are transmitted to the appropriate regulatory agencies. The data were evaluated using the appropriate environmental regulatory criteria. Detalled data for the Calendar Year (CY) 1990 are presented in Appendix D.

\subsection{Airborne Effluents}

Most of the airborne radioactive effluents at BNL originate from the HFBR, BLIP, MRR, and the research Van de Graaff. Argon-41, oxygen-15, and tritium were the predominant radionuclides. In $1990,1,046 \mathrm{Ci}(38.7 \mathrm{TBq})$ of argon-41 were released from the MRR stack; $700 \mathrm{Ci}(25.9 \mathrm{TBq})$ of oxygen-15 were released from BLIP; and $32 \mathrm{Ci}(1.2 \mathrm{TBq})$ of tritium in the form of water vapor were released from the $3 \mathrm{MeV}$ Van de Graaff, Chemistry, and HFBR stacks. In 1990, no elemental tritium was released from the $3 \mathrm{MeV}$ Van de Graaff because tritium was not used as a source of ions. Much smaller quantities of airborne radioactive effluents were released from the Hot Laboratory and the HWMF.

\subsection{Liquid Effluents}

Liquid discharge limits for radiological and non-radiological parameters are subject to conditions listed in the BNL (SPDES) Permit No. NY-000-5835 as issued by NYSDEC. Radiological release concentrations for gross beta, radium, and strontium-90 are also prescribed by the SPDES permit limitations. Other radionuclide discharge concentrations are governed by the U.S. DOE specified Derived Concentration Guides (DCGs). ${ }^{9}$ Since such liquid discharges have the potential of contaminating the "Sole Source Aquifer" underlying the Laboratory, liquid effluent data are compared not only to the regulatory limits, but also to parameters listed in the Safe Drinking Water Act (SDWA).

Operations at the STP were generally (99.8\%) within the limits specified by the SPDES permit. Radioactive concentrations in waste water entering the BNL STP continued to decline from 1988 levels. Gross beta and cesium-137 concentrations in chlorine house effluent remained higher than concentrations found in the influent. This condition is the result of continued low-level leaching of material adsorbed on the sand filter beds as a result of a 1988 unplanned release of cesium-137 and strontium-90 to the sanitary system. In 1990, discharges to the Peconic River met all radioactive components of the SPDES program. The principle radionuclides released to the Peconic River from liquid effluents discharged from the $\mathrm{STP}$ were: $1.4 \mathrm{Ci}(0.051 \mathrm{TBq})$ of tritium, $0.0044 \mathrm{Ci}(0.16$ 
$\mathrm{GBq})$ of cesium-137, $0.00059 \mathrm{Ci}(0.022 \mathrm{GBq})$ of lodine-131 and $0.00007 \mathrm{Ci}(0.0026$ $\mathrm{GBq}$ ) of strontium-90. The annual average tritium concentration at the discharge point to the Peconic River was $0.08 \%$ of the $\mathrm{DCGs}^{9}$ and only $7.6 \%$ of the BNL administrative limit. This represents a factor of 1.6 reduction in the tritium releases to the Peconic River from 1989 values. This reduction in source term was the result of the HFBR not operating in 1990. The annual average cesium-137 concentration was $0.16 \%$ of the DCG (4\% of the SDWA) while strontium-90 concentrations were $0.8 \%$ of the SPDES 1 imit and $0.2 \%$ of the SDWA 1imit. Releases of iodine-131 were $0.02 \%$ of the DCG, $0.6 \%$ of the SDWA concentrations.

Non-radiological parameters are monitored in accordance with the conditions of the SPDES permit. These parameters include residual chlorine, metals, $\mathrm{pH}$, temperature, $\mathrm{BOD}_{5}$, flow, suspended and total solids, fecal and total collform and ammonia-nitrogen. Although there was a $99.8 \%$ compliance rate, several of these parameters periodically deviated from permit conditions. Specifically, there were five occurrences where suspended sclids exceeded the maximum dally value of $10 \mathrm{mg} / \mathrm{L}$ with the highest occurrence being three times the SPDES permit limit and one instance where total coliform was observed above the SPDES 1imits. The presence of elevated suspended solids was believed to be a result of actions taken by the STP operator to control pH.

Periodically, NYSDEC performs compliance verification sampling. On March 13, 1990, representatives from NYSDEC collected a grab sample of the STP effluent (Outfall 001). The results indicated the presence of $1,1,1$-trichloroethane (TCA), a parameter not listed in the BNL SPDES permit, at a concentration of 39 $\mathrm{ppb}$. The TCA concentration was $78 \%$ of surface water discharge limits. Based on these results, NYSDEC requested BNL to add collection and analysis of monthly grab sample from Outfall 001 to the EM Program in order to verify the presence of this: compound in the STP effluent. Brookhaven National Laboratory modified the EM Program and added VOC results to the Monthly Discharge Monitoring Report in July, 1990. Samples collected for VOC analysis were analyzed by an off-site NYS certified laboratory. The results indicated that TCA was below the instrument detection limits in all samples collected during this period.

Liquid effluent discharged to the on-site recharge basins contained only trace quantities of radioactivity. These concentrations were all small fractions of. the applicable guides or standards. If the recharge basin water were to be used as the sole source of drinking water, the resultant dose from direct ingestion at the concentrations detected would be equivalent to a dose of less than $0.01 \mathrm{mrem}(0.0001 \mathrm{mSv})$ per year. Since recharge basins function as conduits to the underlying aquifer system, the non-radiological water quality parameters used in assessing the discharges were the New York State Drinking Water Standards (NYS DWS). Although discharges to recharge basins typically met NYS DWS, several exceptions were observed. At Recharge Basins HN (Outfall 002), HO (Outfall 003), and HS (Outfall 005), pH was periodically observed to be below the minimum discharge limit of 6.5. The lowest observed $\mathrm{pH}$ was 4.8 at Recharge Basin HS. This basin receives principally storm water run-off from paved areas. Precipitation at $\mathrm{BNL}$ has a pH that typically is around 5.0. Elevated iron concentrations were observed above NYS DWS at Recharge Basins HN, HO, and HS at concentrations ranging from 1.3 to 1.9 times the NYS DWS of $0.3 \mathrm{ppm}$. It should be noted that NYS has specific standards for discharges to ground water. These discharges were within this standard for iron. 
As part of the SPDES permit renewal process, BNL collected samples from recharge basins for organic analyses. The results, which were submitted to NYSDEC in February, 1990, observed the presence of TCA in Basin HP. As part of their compl. iance verification process, NYSDEC collected samples from BNL recharge basins on March 13, 1990. The results of the analyses performed on these samples indicated the presence of TCA at Recharge Basin HP (Outfall 004) at a concentration that exceeded the effluent limitation by a factor of four. At the Water Treatment Plant (WTP) Recharge Basin (Outfall 007), Iron was detected at a concentration that exceeded the effluent limitation by a factor of seven. Based on these data, a Notice of Violation (NOV) was issued. The source of the TCA was identified as ground water obtained from Supply We11s 104 and 105 which provided secondary cooling to the MRR. The use of these wells was terminated upon the determination that they were the source of the organic contamination. The elevated iron concentrations at the WTP recharge basins are the result of the backwash discharge from the WTP iron removal system. The NYSDEC is modifying the proposed SPDES permit to require iron monitoring requirements. Brookhaven National Laboratory is also developing a program to evaluate the impact of discharging WTP backwash to the recharge basin.

\subsection{External Radiation Monitoring}

Thermoluminescent dosimeters were used to monitor the external exposure at on-site and off-site locations. The average annual on-site integrated dose for 1990 was $61.2 \pm 7.5 \mathrm{mrem}(0.61 \pm 0.075 \mathrm{mSv})$, while the off-site integrated dose was $60.3 \pm 6.3 \mathrm{mrem}(0.60 \pm 0.06 \mathrm{mSv})$. These doses are essentially equal to those measured in 1989. The difference between the on-site and off-site integrated exposure is within the uncertainty of the measurement and is attributable to the higher terrestrial component of the natural background onsite, ${ }^{10}$ not $B N L$ activities. These values are much lower than amblent exposure rates typically reported for the New York City area by the Environmental. Protection Agency (EPA) which predict an annual dose of about $80 \mathrm{mrem}$ (0.80 $\mathrm{mSv}) \cdot 11-14$

\subsection{Atmospheric Radioactivity}

Tritium was the radioactive effluent detected most frequently in environmental air samples. The maximum annual average tritium concentration at the site boundary was $7.9 \mathrm{pCi} / \mathrm{m}^{3}\left(0.29 \mathrm{~Bq} / \mathrm{m}^{3}\right)$. This concentration would result in a committed effective dose equivalent of $0.0062 \mathrm{mrem}(0.000062 \mathrm{mSv})$ to the maximally exposed individual residing at the site boundary for the entire year. At Station 16T2.1, iodine-126 was detected on one of the January, 1990 air particulate filters. No unusual releases occurred from any facility during January and the charcoal filter for the sample period did not contain detectable concentrations of iodine-126. This result is believed to be suspicious in nature. The committed effective dose equivalent to the maximum individual resulting from the inhalation of the measured air concentration would be 0.001 mrem $(0.00001 \mathrm{mSv})$ if the datum is valid. 


\subsection{Radioactivity in Precipltation}

In ralnfal1, only beryl11um-7 and strontium-90 were detected. The measured concentrations were consistent with typical washout values associated with atmospheric scrubbing ${ }^{15}$ and are comparable with the 1989 and 1990 data published by EPA for Yaphank, New York. ${ }^{11-14}$

\subsection{Sol1 and Vegetation}

The off-site soil and vegetation sampling program is a conperative effort between BNL and the Suffolk County Department of Health Services (SCDHS). Local farms situated around BNL were sampled in July, 1990. No nuclides attributable to Laboratory operations were detected in any of these samples.

\section{$2.7 \quad$ Surface Water}

The Faconic River was sampled at three locations on-site and four locations between the site boundary and Riverhead. In addition, Carmans River was sampled as the background location and Halfmoon Pond was sampled as part of a special study. In general, Peconic and Carmans River samples were analyzed for gross alpha, gross beta, tritium, strontium-90, and gamina emitting radionuclides. Surface water samples were also analyzed for field parameters such as pH, conductivity, and dissolved oxygen. Peconic River samples from the former site boundary (Location HM) were also analyzed for metals and water quality parameters.

Radiological results from samples collected at the former site boundary (Location $\mathrm{HM}$ ) indicate that the annual average gross beta concentration was 4.98 $\mathrm{pCi} / \mathrm{L}(0.18 \mathrm{~Bq} / \mathrm{L})$ or $10 \%$ of the NYS DWS; the average strontium-90 concentration was $0.06 \mathrm{pCi} / \mathrm{L}(0.002 \mathrm{~Bq} / \mathrm{L})$ or $0.8 \%$ of the NYS DWS; the average cesium-137 concentration was $2.0 \mathrm{pCl} / \mathrm{L}(0.074 \mathrm{~Bq} / \mathrm{L})$ or $2 \%$ of the SDWA; and the average tritium concentration was $0.8 \mathrm{nCi} / \mathrm{L}(30 \mathrm{~Bq} / \mathrm{L})$ or $4 \%$ of the NYS DWS. At the current site boundary (Location HQ), the annual average gross beta concentration was $4.6 \mathrm{pCi} / \mathrm{L}(0.17 \mathrm{~Bq} / \mathrm{L})$ or $9 \%$ of the NYS DWS and the average tritium concentration was $1.03 \mathrm{nCi} / \mathrm{L}(38 \mathrm{~Bq} / \mathrm{L})$ or $5 \%$ of the NYS DWS. Nuclide specific gamma analyses were performed at this location with cesium-137 being the principal isotope detected at a concentration of $1.8 \mathrm{pCi} / \mathrm{L}(0.067 \mathrm{~Bq} / \mathrm{L})$ or $2 \%$ of the SDWA.

The Carmans River and Peconic River off-site were sampled in the first, third, and fourth quarter of 1990. No sampling was performed in the second quarter due to activities related to the DOE Tiger Team Assessment, ${ }^{16}$ In Carmans River water, the average gross beta concentration was $1.0 \mathrm{pCi} / \mathrm{L}(0.037 \mathrm{~Bq} / \mathrm{L})$ and the average strontium-90 concentration was $0.18 \mathrm{pCi} / \mathrm{L}(0.007 \mathrm{~Bq} / \mathrm{L})$. These values represent ambient background. Average gross beta concentrations in the Peconic River were uniform and ranged from $1.53 \mathrm{pCi} / \mathrm{L}(0.057) \mathrm{Bq} / \mathrm{L})$ to $1.88 \mathrm{pCi} / \mathrm{L}(0.07$ $\mathrm{Bq} / \mathrm{L}$ ) or $3-4 \%$ of the NYS DWS. Tritium concentrations decrease with distance from BNL with the closest off-site sampling point (Location HA) having an average concentration of $480 \mathrm{pCi} / \mathrm{L}(17.9 \mathrm{~Bq} / \mathrm{L})$ or $2 \%$ of the NYS DWS while samples collected at the Riverhead sampling point (Location $H R$ ) had an average concentration of $280 \mathrm{pCi} / \mathrm{L}(10.4 \mathrm{~Bq} / \mathrm{L})$ or $1.4 \%$ of the NYS DWS. Nuclide specific analyses indicated that strontium- 90 concentrations wert consistent with ambient 
levels and ranged from $0.12 \mathrm{pCl} / \mathrm{L}(0.004 \mathrm{~Bq} / \mathrm{L})$ to $0.54 \mathrm{pCl} / \mathrm{L}(0.02 \mathrm{~Bq} / \mathrm{L})$. Cesium-137 was detected periodically in downstream water samples. The observations did not follow site release patterns. The average cesium-137 concentrations detected ranged from $0.17 \mathrm{pCl} / \mathrm{L}(0.006 \mathrm{~Bq} / \mathrm{L})$ to $0.60 \mathrm{pCl} / \mathrm{L}(0.02$ $\mathrm{Bq} / \mathrm{L}$ ), or 0.1 to $0.5 \%$ of the SDWA. Direct Ingestion for one year of 211 ters of water per day containing the maximum observed cesium-137, strontium-90, and tritium concentration would result in a committed effective dose equivalent of 0.1 mrem $(0.001 \mathrm{mSv})$ at al1 1ocations.

Field and water quality parameters were consistent with both past observations and control data. Metal data for analyses performed on monthly samples collected from Location HM indicated that iron was the only parameter that exceeded NYS DWS. Effluent from the BNL STP to the Peconlc River had an iron concentration $0.16 \mathrm{ppm}$. The high values of 1ron in the Peconic River water are the result of ground water recharge into the Peconic River,

\subsection{Aquatic Biologlcal Survell1 ance}

Fish samples were collected along the Peconic River at the outfall of the STP (Location EA), the former site boundary (Location HM), Donahue's Pond, and Forge Pond, at the upstream location of Swan Pond and at a control location along Carmans River. In CY 1990, only gamua spectroscopy analysis was performed on samples collected. Strontium-90 analyses were not performed due to fallure of the contract laboratory to meet quality assurance obfectives and the inability to issue a new contract prior to the first quarter of 1991 . For dose assessment purposes the strontium-90 to cesium-137 ratio as reported in the 1989 BNL SER has been used to estimate the strontium-90 component of the fish-ingestion pathway. The Peconlc River fish contained casium-137 concentrations which ranged from near background levels at Forge Pond (100 - $460 \mathrm{pCi} / \mathrm{kg}$-wet $[3.7-17 \mathrm{~Bq} / \mathrm{kg}$-wet]) to $1,650 \mathrm{pCi} / \mathrm{kg}$-wet $(61 \mathrm{~Bq} / \mathrm{kg}$-wet) at Location EA. Average concentrations found in control aquatic biota were subtracted from results for Peconic River sample stations. Only fish collected at off-site locations were used to calculate the maximum individual and collective doses. Based on these results, the maximum individual dose was estimated to be $0.75 \mathrm{mrem}(0.0075 \mathrm{mSv})$ and the collective dose was stimated to be 0.375 person-rem ( 0.00375 person-Sv). No sediment or aquatic vegetation samples were collected in 1990.

\subsection{Potable Water Supply}

Gross alpha, gross beta, and tritiun concentrations in samples collected from on-site polable wells were generaliy at or below the minimum detection limit (MDL). The dally grab sample of potable water collected from a central bullding on-site exhibited the same results. Tritium concentrations in on.site potable well water were at or below the MDL of $300 \mathrm{pCi} / \mathrm{L}(11 \mathrm{~Bq} / \mathrm{L})$. Strontium-90 concentrations were at or below the MDL of $0.1 \mathrm{pCl} / \mathrm{L},(0.004 \mathrm{~Bq} / \mathrm{L})$ and consistent with concentrations in off-site wells. Orily ceslum-137 and berylifun-7 were detected above MDL levels at annual average concentrations of $0.13 \mathrm{pCl} / \mathrm{L}(0.005$ $\mathrm{Bq} / \mathrm{L})$ and $11 \mathrm{pCi} / \mathrm{L}(0.4 \mathrm{~Bq} / \mathrm{L})$ respectively. These concentrations, if consuned for one year at a rate of two liters per day would correspond to a committed effective dose equivalent to the on-site resident of $0.005 \mathrm{mrem}(0,00005 \mathrm{mSv})$. These doses represent an upper limit to the dose actually received because the concentrations used to derive these doses were obtained from analyzing samples 
from the individual well heads and does not acount for mixing that would ocour when the water is distributed throughout the site.

Metal analyses performed on potable water samples indicate that silver, cadmium, chromlum, and mercury were not detected in any sample analyzed. Trace quantities of lead $(0.005 \mathrm{mg} / \mathrm{L})$, manganese $(0.02-0.14 \mathrm{mg} / \mathrm{L})$, and copper $(0.09$ $\mathrm{mg} / \mathrm{L}$ ) were detected in potable well water collected at the we1l head. All observed values of lead, manganese, and copper were below the1r respective NYS DWS of $0.050 \mathrm{mg} / \mathrm{L}, 0.3 \mathrm{mg} / \mathrm{L}$ and $1.0 \mathrm{mg} / \mathrm{L}$. Iron was dotected in water collected at the well head from We11. Nos, 4, 6, and 7. Water from these wells is treated at the BNL WTP prior to use in the domestic water distrlbution system. Sodfum was datected in a11 potable walls in concentrations ranging from 3,3 to 13,0 $\mathrm{mg} / \mathrm{L}$.

In order to demonstrate compliance with federal and gtate DWS for organic compounds, potaisle water is sampled quarterly and sent to an off-site certifled Laboratory for analysis. In October, 1990, water from Potable We11 4 was detected to have TCA at a concentration of $7.5 \mu \mathrm{g} / \mathrm{L}$ which exceeds the NYS DWS of $5 \mu \mathrm{g} / \mathrm{L} .{ }^{17}$ The well was voluntarily removed from servic 3 .

Prior to obtaining these results, BNL was concerned with the increasing concentrations of TCA being observed in this well during previous quarterly sampling. In an effort to further investigate this, a testing program was developed to evaluate the ability of the existing processes at the BNL WTP to removed organic compounds. To ensure the merit of this testing program, the proposed protocol was discussed with a representative from the SCDHS.

The testing program was conducted in October, 1990. A package was prepared describing the test protocol and analytical results, and submitted to the SCDHS for their review and evaluation. A decision from the DHS is anticipated to be issued during the first quarter of 1991.

In 1989, TCA concentrations that exceeded NYS DWS were observed at Potable We11s 10 and 11. A carbon filtration system was purchased for Potable We11 11. Installation of this device is expected to be completed in 1991. A similar system will be purchased for Potable Well 10.

\subsection{Ground Water Survelllance}

Ground water survelllance data are compared to both DCGs and DWS values in this report. The DCG for a given radionuclide represents the concentration which would yield a committed effective dose equivalent of $100 \mathrm{mrem}$ ( $1 \mathrm{mSv}$ ) if an individual were to consume two liters of the liquid per day for one year. Comparison of data to these concentrations permits evaluation of discharge limit impacts and provides a historic framework to evaluate past practices. Comparison of survelllance well data to EPA, NYSDEC, New York State Department of Health (NYSDOH) and DOE DWS provides a mechanism to evaluate the radiological and nonradiological levels of contamination relative to current standards. The Laboratory is comitted to remediate ground water which does not meet current regulatory criteria to the levels prescribed in the Interagency Agreement (IAG). 


\subsection{0 .1 Badiologdeal Analy여요}

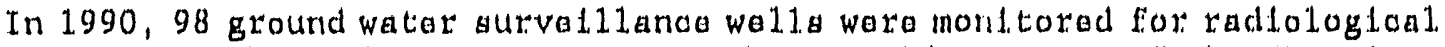
parameters, Radlological data aro prosentad groupod by sactor of tha BNL alto. In the east sector of the site (Meadow Marsh-upland raoharge araa; Pedonto Rivar

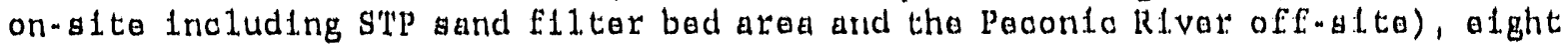
ground water wolls wore monttored, Gross beta and tritum condentrations wore dateated which ware above amblent concontrations in the on-stea araas nar the peconto River. Also, at an offuste woll that is adjacent to the Poconto River: and within soveral hundred meters of the site boundary, elovated gioss beta, tritium, and atrontum-90 concentration ware detocted, Radionuclida concantrations near the Madow Marshupland recharge area wore at amblant lavals. Obsarved conoentrations in on alta peoonlo Rlvar area walls ara attributabla to tle collection fleld losses at the STP and recharge of the Paconlo Rlver. In 1990, the highest annual average gross beta concentration was $7 \%$ of the NYS DWS concentration Ifinttid tritfum was $11 \%$ of the NYS DWS concontration limit; strontium-90 was $8 \%$ of the NYS DWS concentration 1 imt. At a single survalilanou well located adjacent to the Peconto Rfver and geveral hundred maters downstram of the ste boundary, the annual average gross beta conoentration was $11 \%$ of the NYS DWS; the trittum concentration was $9 \%$ of the NYS DWS and the strontiuma 90 concentration was $24 \%$ of the NYS DWS concontration 11mit. No gamma emitting radionuclides were detected at any woll in this area,

Along the northwest, west, and south boundary of the s1te, 13 walls were mont tored. No activity above amblent levels or signiflcantly in excess of the system MDL was found in ground water samples collected from these areas axcept for gross beta activity observed in March, 1990 samples from We11 130-02, a south boundary we11. The samples were milky in color and believed to contaln bentonlte clay from the woll packing whlch would explatn both the color: and elevated gross bota activity.

In the center of the alte, 27 survelllance wells ware monttored, Radjonuclides detected in ground water samples that ware attributable to BNL operations were found in the viclntty of Bullding 811, Bullding 830, the Major Petroleum Facility (MPF), and Bulling 725. The highest annual average concentrations detected for this area expressed as a percent of the NYS DWS concentration 1.inft were: $12 \%$ gross beta; $2.4 \%$ tritium; and $14 \%$ strontium-90. Radionuclides that are not regulated by concentration are regulated by dose. The highest annual concentration clatected for the remaining radionuclides expressed 1r percent of the dose 1 imlt were: $1.4 \%$ sodium-22; $0.11 \%$ cestum-137; and $0,09 \%$ cobalt -60 .

In addition to the BNL on-site survelilance we11.s, 20 off-site private potable wells and three locations along the Peconic River near the site boundary were sampled and analyzed for gross alpha, gross beta, strontium-90, tritium, and gamina emitting radionuclides as part of a cooperative program with the SCDHS. Detectable quantities of trittum were found in three off-site sampling locations: two private potable wells and one Peconic River sampling polnt. The annual average tritium concentrations at the two private well. locations was $10 \%$ of the DWS.19 Except for naturelly occurring potassium-40, no gamma emitting radionuclides were detected in private we11. water and strontium-90 values ranged 


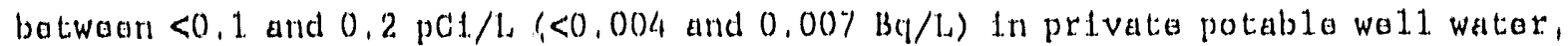
whitah la typtad for long Ioland.

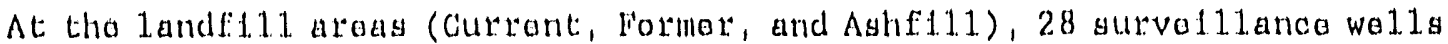
wate mont torad. Tha singla highast averaga gross bata concantration observed was $35 \%$ of tha applicable guldo; the singlo highest avorage tritidun concentration and atront fum-90 consentration observed were $95 \%$ and $63 \%$, respectively of the DWS,

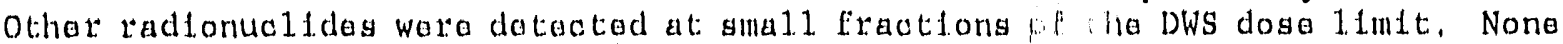
of the mant toring walls that ware sampled axhlbltod cowsuntrations that exceeded tha DWS, although water from Wa11 87.08 (1K) at the Curront Landfill is very alose to the tritfun DWS, Glvan the distance to the sito boundary, decay will oocur in tranglt which will ragult in radionuolido ooncentrations at the site boundary that are substantialiy below the applicable standard.

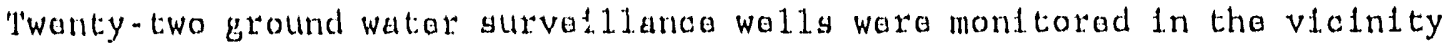
of the HWMF. The date from this ground watar progran indleates the presence of trittun, fisston, and activation products. The single highest avarage concantration of tritfum and stront 1 um- 90 was $27 \%$ and $760 \%$, respectively of the DWS, The highast annual concontration for the remafning radionuclides detected expressed in percent of tha DWS close 11 int wara: $0.28 \%$ cobalt-60 and $0.04 \%$ sodfum-22. Three of the 22 monttorfing wolls that were sampled in this area oxhibltad concantrations that axceoded the NYS DWS for strontium-90; 88-04 (MW2); 98.02 (WC); and 98.29 (MW7A).

\subsection{0 .2 Non-radtologloal Analyses}

In the east sector of the st.te (Meadow Marsh-upland recharge area; Pecontc River on-gite; and Peconfo RIvor off-glte) water qualfty, metals, and VOC analyses ware performad on alght ground water survelliance wells, Water quality data indicated that the pH was typlcally bolow the NYS DWS of 6.5 to 8.5 but within typlcal obsarvations of ground water that ls upgradient of the BNL site. Other water quality paraneters were al1. within the DWS. Iron and manganese were the only metals observed in concentrations that exceeded the DWS, Like low pH, elovated concentrations of tron and manganese are endemic to Long Island. At the observed concentration, the presence of these metals is not reflective of BNL operations. The VOCs wore not detected in ground water collected from this area of tho stite.

In the landfill and ash roposttory section of the site, water quality, motals and VOC analyses were performed on 28 ground water survelliance wells. Wator quallty data indicated that: the pll was typlcally below the NYS DWS of 6.5 to 8.5 but within the range of valuos observed at locations upgradient of: potential site tinpact. Other water quality parameters were within DWS. Conductivity measuraments at the currant landfil wells reflect the landf11's impact. Most conductivity values in this area ware greater than 150 umhos/cm while upgradient values typlcally ranged from 50 to 150 unhus/cm. There is no speciffed standard for conductivity. Metals analysis indicated that water from one of the nine wel.1.s at the former landf111 excoeded the DWS for manganese. At the current landf11, fourtoen of the elghteen wells in this area exceeded the tron and/or manganase standard. A11. other: metals concentrations were below the DWS. Organio data for tho Current landf111. araa indicatas that annual average concentrations of dichloroethane (DCA) were detected above the DWS at three we11s 
rangling from 6 , to $11 \mu \mathrm{g} / \mathrm{L}$; benzene, ethylbenzene, and toluene were each detected In one well above the DWS at concentrations of 9,8 , and $12 \mu \mathrm{g} / \mathrm{L}$, respectively. Organic compounds were not detected from ground water survelilance wells that monitor the former landfili and the ash repository.

In the Hazardous Waste Management (HWM) and Spray Aeration Profect areas, twenty-two ground water survelliance wells were monltored for water quality, metals, and VOCs. Water quality data indicated that the pH was typlcally below the NYS DWS of $6,5,-8.5$ but within the range of values observed at locations upgradient of potential site impact, Other water quality parameters were below the applicable NYS DWS. Conductivity values were all in the 50 - 150 umhos/cm range. Results of metals analyses performed on ground water from this area Indicated that al1 compounds were below the applicable NYS DWS. Volatile organic results for ground water samples collected from this area indicate that I'CA, tetrachloroethylene (PCE), and dichloroethylene (DCE) were detected at concentrations that exceeded the NYS DWS. Spectficaliy, two wells near the HWM facility, 88-04 (MW2) and 98-02 (WC) had concentrations of TCA that ranged from 85 to 1000 $\mu \mathrm{g} / \mathrm{L}$. We11 88-04 also had PCE concentrations greater than $150 \mu \mathrm{g} / \mathrm{L}$ while well 98-02 had DCE concentrations of $52 \mu \mathrm{g} / \mathrm{L}$. Near the BNL site boundary, TCA concentrations ranged from 8 to $30 \mathrm{ppb}$ at three We11s: 108-13, 108-05, and 108. 12. No other organic compounds were detected in this area of the site.

In the central part of the site, 28 ground water survelilance wel.1s were monitored for water quality parameters, metals, and VoCs. Water quality data indicated that the pH was typically below the NYS DWS of $6.5-8.5$ but within the range of values observed at locations upgradient of potential site impact. Other water quality parameters were below the applicable NYS DWS. Conductivity values were generally all in the $50-150$ umhos/cm range however two wells in the Central Steam Facility (CSF) area, 76-05 (IT5), and 76-06 (IT2), had conductivity values in the $300-350$ umhos/cm range while four wells (54-05 [DOE Well 556], 65-03 [D10], 65-04 [D11], and 65-02 [D9]) in the AGS - Building 811 area, had conductiyity values in the $150-250$ umhos/cm range. Results from metals analyses of ground water from this area indicated that all compounds were below the applicable NYS DWS except for iron and manganese. At the CSF, water from Wells 76.04 (IT1) and 76-06 (IT2) exceeded the $0.3 \mathrm{mg} / \mathrm{L}$ iron NYS DWS while water from We11s 76-04 (IT1) and 76-08 (IT4) contalned manganese concentrations in excess of the $0.3 \mathrm{mg} / \mathrm{L}$ NYS DWS. The iron concentration in water from We11 44-04 (DOE Wel1 558) also exceeded the NYS DWS. Volatile organic results for ground water samples collected from this area indicate that TCA, trichloroethylene (TCE), PCE, DCA, benzene, ethylbenzene, toluene, and o-zylene were detected at concentrations that exceeded the NYS DWS in ground water sampled from seven wells located at the CSF. The maximum observed annual average concentration for each of these compounds was: $22 \mu \mathrm{g} / \mathrm{L}$ of TCA; $33 \mu \mathrm{g} / \mathrm{L}$ of TCE; $130 \mu \mathrm{g} / \mathrm{L}$ of PCE; $5 \mu \mathrm{g} / \mathrm{L}$ of DCA; $12 \mu \mathrm{g} / \mathrm{L}$ of benzene; $100 \mu \mathrm{g} / \mathrm{L}$ of ethylbenzene; $480 \mu \mathrm{g} / \mathrm{L}$ of toluene and $60 \mu \mathrm{g} / \mathrm{L}$ of o-xylene. The NYS DWS for each of these compounds is $5 \mu \mathrm{g} / \mathrm{L}$. No other organic compounds were detected in this area of the site.

In the north, west, and southern parts of the site, 13 ground water surveillance wells were monitored for water quality parameters, metals, and VOCs. Water quality data indicated that the pH was typically below the NYS DWS of 6.5 8.5 but within the range of values observed at locations upgradient of potential site impact. Other water quality parameters were below the applicable NYS DWS. 
Conductivity values were all in the $50-155$ urnhos/cm range. Results from metals analyses of ground water from this area indicated that all compounds except iron and manganese were below the applicable NYS DWS. Iron concentrations exceeded NYS DWS at two wells on the north boundary and one well along the south boundary. Manganese concentrations exceeded INYS DWS at one well on the north boundary and one well on the west boundary. Volatile organic results for ground water samples collected from this area indicate that only TCA was detected in concentrations that exceeded NYS DWS. The TCA was observed at a concentration of $9 \mu \mathrm{g} / \mathrm{L}$ at both a well along the western side of the site designed to monitor the impact of operations at the BNL Paint Shop and along the southern boundary.

\subsection{Off-Site Dose Estimates}

For the year 1990, the collective committed effective dose-equivalent attributable to Laboratory operations, for the population up to a distance of 80 $\mathrm{km}$, was calculated to be 1.8 person-rem ( 0.018 person-Sv). This can be compared to a collectio dose-equivalent to the same population of approximately 290,000 person-rem (2900 person-Sv) due to natural sources.

The committed effective dose-equivalent to the maximum individual resident at the site boundary (NNE Sector) from the air pathway is $0.066 \mathrm{mrem}(0.00066$ $\mathrm{mSv}$ ). The maximum individual committed effective dose-equivalent from drinking water pathway (SSE Sector) is $0.1 \mathrm{mrem}(0.001 \mathrm{mSv})$. The maximum individual comitted effective dose-equivalent from the fish pathway is 0.75 mrem $(0.0075$ $\mathrm{mSv})$. The combined maximum individual dose equivalent is 0.9 mrem $(0.009 \mathrm{mSv})$. This dose represents $0.9 \%$ of the maximum individual annual close limit of $100 \mathrm{mrem}$ ( $1 \mathrm{mSv}$ ) and $1.6 \%$ of the annual cosmic plus terrestrial external dose of about 60 mrem $(0.60 \mathrm{mSv})$.

\subsection{Quality Assurance Program}

Brookhaven National Laboratory has implemented DOE Order $\mathrm{CH} 5700.6^{20}$ by developing policies, responsibilities, and providing generic guidance procedures for the development of QA programs that are appropriate to ensure the achievement of Laboratory objectives. ${ }^{21}$ The elements of this program have been adopted and adapted, as necessary, by the S\&EP Division in the development of the Division's QA prograa. ${ }^{22}$ Established protocols that document the specific activities of the EM program are collected in the S\&EP EP Section QA Manual. A designated QA Officer was appointed to review procedures and activities within the EP Section and to assure that environmental and effluent monitoring or upgrade programs comply with the S\&EP, BNL, and DOE QA objectives.

The level of quality control and quality assurance activities depend on the nature and frequency of measurements. Checks on instrument performance and on overall quality of the data we re made with measurement control charts and with certified control organization. Samples were processed with quality control, which included using blanks, replicates, and spikes. The analytical laboratories participated in interlaboratory QA programs organized by DOE, EPA, and NYSDEC agenc; $\in$ s. 


\subsection{EFFLUENT EMISSIONS AND ENVIRONMENTAL SURVEILLANCE}

The primary purpose of BNL effluent and environmental monitoring programs is to determine whether:

1. Facility operations, waste treatment, and control systems functioned as designed to contain environmental pollutants; and

2. The applicable environmental standards and effluent control requirements were met.

This annual report for CY 1990 follows the recommendations given in the DOE Order 5400.1, General Environmental Protection Program. ${ }^{23}$

\subsection{Airborne Effluent Fissions}

\subsubsection{Radioactive Ai-borne Effluent Emissions}

The locations of principle Laboratory facilities from which radioactive airborne effluents were released during 1990 are shown in Figure 9 . The installed on-line effluent monitors, sampling devices, and amounts of effluents released during 1990 are presented in Appendix D, Table 4. Tritium was the only radionuclide detected routinely at the site boundary which was attributable to Laboratory operations. Iodine-126 was detected on one site boundary particulate filter during the month of January but not on the corresponding charcoal filter. There were no unusual effluent releases or processes that would explain the presence of this radionuclide during the sample interval. Furthermore, because the radionuclide was detected on only the particulate filter and not the corresponding charcoal filter, there is some question as to the validity of the datum point. The datum is presented because there was no technical justification for removal. It should be viewed as an outlier whose validity is questionable.

Oxygen-15, which has a two minute half-life, is produced at the BLIP facility by the interaction of protons and water in the beam tubes and generated at an estimated rate of $6 \mathrm{mCj}$. per microampere-hour $(0.22 \mathrm{GBq}$ per micro amperehour). ${ }^{24}$ Based on 117 milliampere-hours of operation, $700 \mathrm{Ci}(26 \mathrm{TBq})$ of oxygen-15 was produced in the beam tubes at the BLIP facility during 1990 and released via the Building 931 stack. Due to scheduled maintenance at the LINAC and AGS, BLIP did not operate during the months of June through December, 1990. Monthly effluent emissions are listed in Appendix D, Table 5 .

Argon-41, which has a 11J-minute half-1ife, is produced at the MRR by neutron activation of stable atoms of argon-40 in the ventilating air of the reflector. It is released from the Building 491 stack at an estimated rate of $2.1 \mathrm{Ci} \mathrm{MW}{ }^{-1} \mathrm{~h}^{-1}\left(78 \mathrm{GBq} \mathrm{MW} \mathrm{MW}^{-1}\right)$. The estimated release for the MRR stack during 1990 was $1,046 \mathrm{Ci}(39 \mathrm{TBq})$ of argon-41. Monthly effluent emissions are 1isted in Appendix D, Table 5. The MRR did not operate from April through July, 1990 due to SPDES issues related to the discharge of secondary cooling water. A detailed discussion of this issue is discussed in Section 3.2.3.2 of this report. During the April to July time period, modifications to the secondary cooling system were made so that BNL's potable water could be used to supply secondary 
cooling water. The MRR commenced operation in August at 1 MW using water supplied by the potable water system. From August to the end of the year, the MRR operated at the reduced power level.

The total tritiated water vapor released from the Laboratory research facilities during 1990 was $31.8 \mathrm{Ci}(1.2 \mathrm{TBq})$. Of this total, $24.3 \mathrm{Ci}$ (0.9 TBq) were released from the HFBR, $4.4 \mathrm{Ci}(0.16 \mathrm{TBq})$ from the Van de Graaff, and the remainder from all other facilities. Appendix $D$, Tables 6 and 7 present monthly summaries of tritium release data.

The Building 705100 -meter stack receives airborne effluents from three separate exhaust systems: the HFBR (Building 750) and the Hot Laboratory (Building 801) acid and non-acid lines. Gamma emitting nuclides released from the 100-meter stack are shown in Appendix D, Tables 7, 8, and 9. Tritium is the major radionuclide released from the HFBR. Because the HFBR did not operate in 1990, tritium releases are substantially lower than prior year's releases. The HFBR is scheduled to resume operation in 1991. Tritium releases from this facility will increase when the facility comes on-line and research activities are resumed. The Hot Laboratory complex air effluent release from the acid and non-acid off-gas systems are reported in Appendix D, Tables 8 and 9, respectively. These releases are the result of processing BLIP targets for the recovery of radioisotopes used by medical health practitioners. Releases from this facility were at their maximum during the period of March through May. This corresponded to an increase in work load in anticipation of the summer shut-down of the facility. In 1990, releases of gallium-68, zinc-65 and rubidium were significantly lower than in 1989 while other radionuclides, such as bromine-77 and the iodines, exhibited an increase in the release rate by a factor of three to nine. Releases from this facility were not detected by air sampling at the site boundary. Appendix D, Tables 8 and 9 appear to indicate that no releases occurred in February 1990. This is an anomaly of the data presentation. The sample media were installed in January and removed in early March. The amount released during February are shown in the January values.

In addition to radionuclides released during the processing of targets from the BLIP Facility, other radionuclides in addition to oxygen-15 are produced at the BLIP Facility and are periodically emitted into the environment. Appendix D, Table 10 summarizes the gamma emitting radionuclides released from this facility. The predominant radionuclide released in 1990 was beryllium-7 $(0.37$ $\mathrm{mCi}(0.014 \mathrm{GBq}])$. The activity released was approximately four times smaller in 1990 than in 1989.

The Laboratory incinerates certain low-level radioactive wastes at the HWMF incinerator (Figure 9). The total quantities of the individual radionuclides in the incinerated materials during 1989 are shown in Appendix D, Table 11. Tritium was the radionuclide released from the incinerator in the largest quantity, $0.0016 \mathrm{Ci}(0.059 \mathrm{GBq})$. Site meteorological characteristics and administrative limits on the amount of material incinerated ensure that airborne concentrations at the site boundary are small fractions of the applicable standards. 


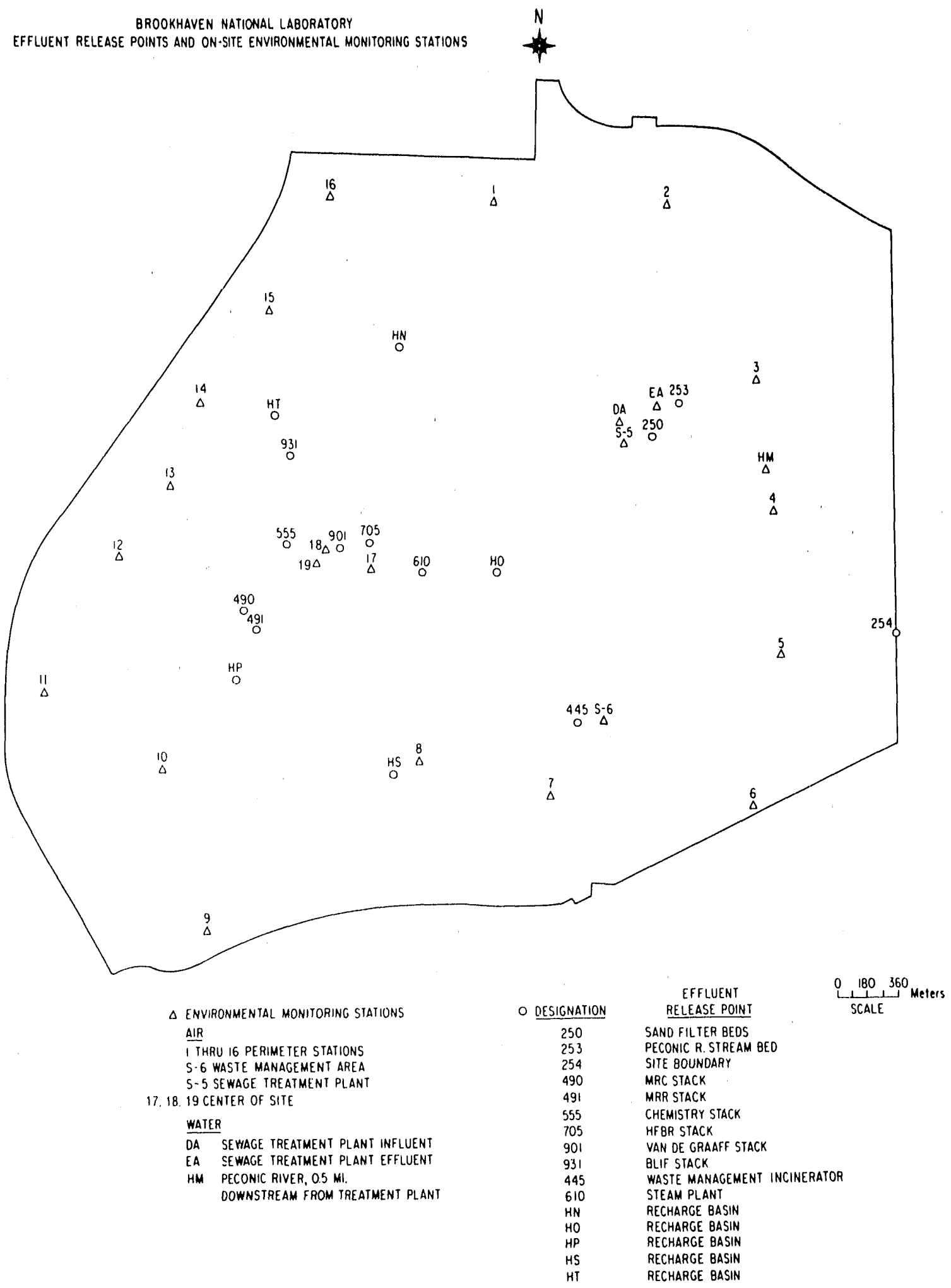

Figure 9: Brookhaven National Laboratory Effluent Release Points and On-Site Environmental Monitoring Stations 


\subsubsection{Nonradioactive Airborne Effluent Emissions}

The potential sources of elemental and hydrocarbon air pollutants emitted by BNL facilities and all environmental permits issued to the DOE at BNL are listed in Appendix D, Table 12. Under the air permits issued by the NYSDEC, five individual stacks require monitoring, three of which are associated with the combustion units at the CSF (Building 610). The other two emission points are associated with new sources at the Inhalation Toxicology Facility located at Building 490 .

The CSF is located along the eastern perimeter of the developed portion of the BNL site. The CSF supplies steam for heating and cooling to all major facilities through the underground steam distribution and condensate grid. Since 1976, the CSF has utilized alternate liquid fuel (ALF) in the four high efficiency boiler units for the purpose of energy recovery. In 1990, the fraction of light feed stock (LFS) relative to total fuel consumption was approximately $1.5 \%$. These LFS fuels typically have a weighted average sulfur content of $0.5 \%$ or less which is below the NYSDEC regulatory limit of $1 \%$ sulfur content in No. 6 oil. ${ }^{25}$ The NYSDEC also requires that the combustion efficiency of the boilers be $99.0 \%$ at a minimum. ${ }^{25}$ Stack testing, conducted in accordance with NYSDEC requirements, has demonstrated the mean fuel combustion efficiency over the entire range of boiler loading capacities to be greater than $99.9 \%$ for the individual boiler units firing $\mathrm{ALF},{ }^{26,27}$ thus providing greater combustion efficiency than required by state criteria. Standard operating Procedures require all LFS samples to be analyzed for polychlorinated biphenyls (PCBs) prior to their use to ensure that the facility operations are conducted in accordance with EPA and NYSDEC regulations.

\subsection{Liquid Effluents}

The basic policy of liquid effluent management at the Laboratory is to minimize the volume of liquids requiring processing prior to on-site release or solidification for off-site burial at a licensed facility. ${ }^{28}$ Accordingly, liquid effluents are segregated by the generator at the point of origin on the basis of their anticipated concentrations of radioactivity or other potentially harmful agents.

\subsubsection{Liquid Waste Management}

Liquid chemical wastes are collected by the Hazardous Waste Management Group (HWMG), and subsequently packaged in accordance with Department of Transportation (DOT), EPA, and NYSDEC regulations and DOE Orders for licensed off-site disposal.

The HWMG also collects small quantities of liquid radioactive wastes from waste accumulation areas throughout the site. Depending on the radionuclide and its concentration, these wastes are either directly solidified at the HWMF or processed at the Waste Concentration Facility (WCF). Buildings where large volumes (up to several hundred liters) of liquid radioactive waste are generated have dual waste handling systems. These systems are identified as "active" (D) and "inactive" (F). As shown in Figure 10, wastes placed into the $D$ and $F$ systems are collected in holdup tanks. After sampling and analysis, they are either authorized for release directly to the sanitary waste system if concentrations are within administrative guidelines for discharge ${ }^{29}$ or are 


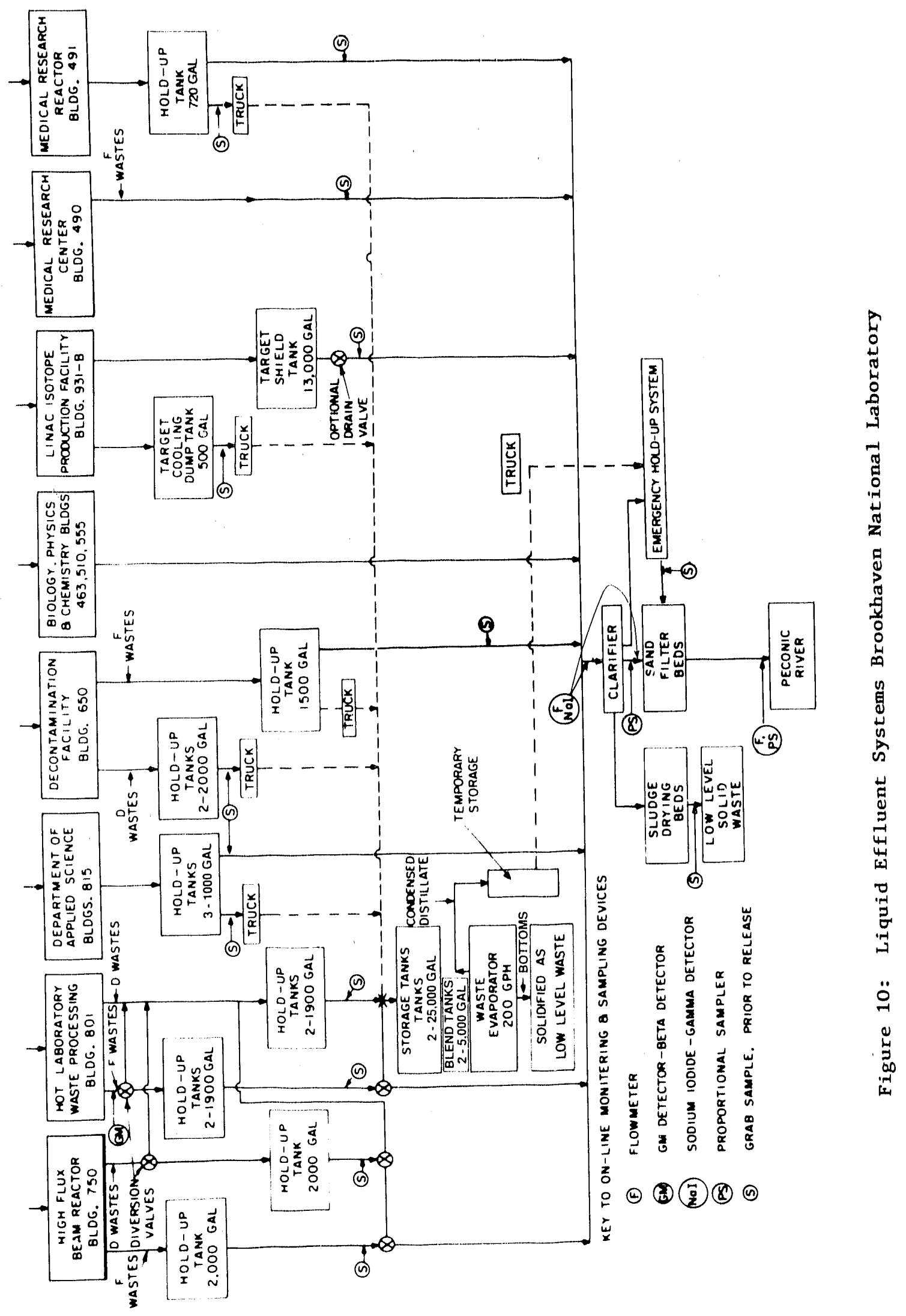


transferred to the WCF for processing. In 1990, authorized releases of F-waste to the sanitary system totaled 1.03 million liters with a total gross beta activity of $0.47 \mathrm{mCl}(17 \mathrm{MBq})$ and a total tritium activity of $22 \mathrm{mCl}(0.81 \mathrm{GBq})$. The volume of material released in 1990 represents a ten percent increase over 1989 while the tritium and gross beta activity released increased by factor of 1.6. Although the total activity released in 1990 is higher than in 1989, these releases remain significantly lower than pre-1989 values.

At the WCF, Iiquid waste is distilled to remove particulate, suspended, and dissolved solids. The solidifled residues from the evaporator are transferred to the HWMF for subsequent shipment and disposal at an authorized off-site disposal facility. The distillate, which contains tritium, is collected and transported to the STP. It is released into a lined hold-up pond where it mixes with precipitation and diverted effluent from the STP. This water is then pumped back to the STP at a controlled rate where it is added to the dosing tanks of the sand filter beds. This process permits a controlled release of liquid effluents and aids the Laboratory in achieving its administrative discharge concentration 1 imit of $20,000 \mathrm{pCi} / \mathrm{L}(740 \mathrm{~Bq} / \mathrm{L})$ and the goal of $10,000 \mathrm{pCi} / \mathrm{L}(370 \mathrm{~Bq} / \mathrm{L})$. By comparison, the $\mathrm{DCG}^{9}$ for tritium is $2,000,000 \mathrm{pCl} / \mathrm{L}(0.074 \mathrm{MBq} / \mathrm{L})$. In 1990, approximately 68,100 liters of distillate containing $0.85 \mathrm{Ci}(31.6 \mathrm{GBq})$ of tritium was placed into the lined holding pond.

\subsubsection{Sanitary System Effluents}

Primary treatment of the sanitary waste stream to remove suspended solids is provided by a 950,000 liter clarifier. The liquid effluent flows from the clarifier onto sand filter beds, from which about $85 \%$ of the water is recovered by an underlying tile field. This recovered water is then released into a small stream that contributes to the headwaters of the Peconic River. The Peconic River is an intermittent stream within the BNL site. From the mid 1980's until April of 1989 , virtually all water released to this channel recharged to ground water prior to reaching the site boundary. Beginning in April, 1989 and continuing throughout 1990 , heavy rains produced sufficient upstream contribution to result in the Peconic tributary on the BNL site to once again leave the site.

The effluent not collected by the tile fields, approximately $15 \%$ in 1990 , is assumed to percolate to the ground water under the beds and/or evaporate. A schematic of the STP and its related sampling arrangements is shown in Figure 11. Real time monitoring of the clarifier influent for radioactivity, pH and conductivity, takes place at two locations: about $1.8 \mathrm{~km}$ upstream of the STP and as the influent is about to enter the clarifier. The upstream station provides about one hour of advanced warning that liquid effluents which may exceed BNL effluent release criteria or SPDES limits have entered the system. At the clarifier, an oil monitor examines STP influent for the presence of oil. Effluent leaving the clarifier is monitored a third time for radioactivity. Effluent that does not meet BNL and/or SPDES effluent release criteria are diverted to one of two lined holding ponds with a 26.5 million liter capacity until the effluent meets the release criteria. Material diverted to the holding pond is evaluated for treatment and released when the addition of this material will not result in exceeding BNL SPDES or administrative release criteria. 


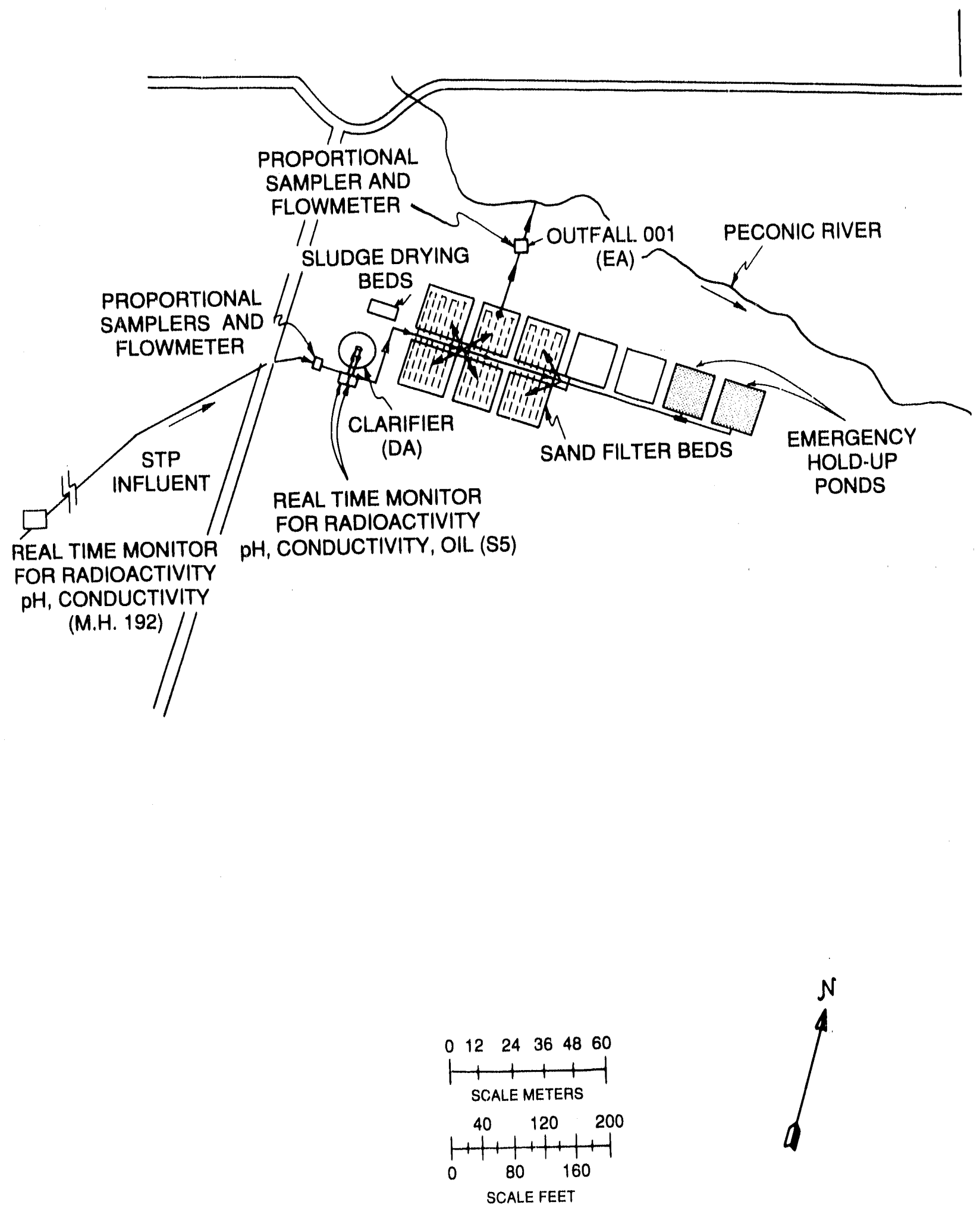

Figure 11: Sewage Treatment Plant - Sampling Stations 
In addition to real time monitoring, the clariffer effluent (Location DA) and the outfall to the Peconic River (Location EA) are monitored for radiological and non-radiological parameters through a combination of volume proportional and grab samples.

\section{2 .2 .1 Radiologlcal Analyses}

The proportional samples collected at Location DA, the effluent from the STP clarifier, Location EA, and the STP discharge point into the Peconic River, are analyzed dally for gross alpha, beta, and tritfum activities. An aliquot is composited for monthly struntium-90 and gamma spectroscopy analyses. The results of these measurements are reported in Appendix D, Tables 13 and 14. Five year trend plots of gross beta and tritium concentrations that were released to the Peconic River are presented in Figures 12 and 13. A total tritium activity trend plot from 1971 to the present is presented in Figure 14.

The gross alpha data at the STP are consistent with prior year's data. A.1. results are essentially less than the system detection 1 imlt and have a mean value which approaches zero. This means that alpha concentration measurements for these locations are at background levels. The tritium concentrations decreased in 1990 on the average by about $40 \%$ below 1989 levels. Th1s occurred in large part because the HFBR didn't operate for the entire year. Controlled releases of WCF distillate from the STP emergency holding ponds continued in 1990 and is the reason that tritium discharges to the Peconic River are larger than influent contributions reported from sampling Location DA. The 1990 tritium concentrations discharged to the Peconic River were below regulatory standards and were within BNL adininistrative controls. The total tritium activity released into the sanitary system was $1.3 \mathrm{Cl}$ ( $48 \mathrm{GBq}$ ) as compared to $2.0 \mathrm{Ci}$ (74 $\mathrm{GBq})$ in 1989. The tritium activity discharged from Location EA was 1.4 Ci ( $51 \mathrm{GBq}$ ) as compared to $2.5 \mathrm{Ci}(92.5 \mathrm{GBq})$ in 1989 . The concentrations of strontiun-90 and gamma emitting radionuclides entering the STP returned to pre-1988 levels. At Location DA, al1 radionuclide concentrations were at or below pre-1988 levels. At Location EA, except for cesium-137, the remaining concentrations are essentially constant with prior year's data. ${ }^{10}$ Elevated cesium-137 concentrations persist at Location EA due to residual leaching of this radionuclide from the sand filter beds. This activity is present due to an unplanned release on June 14 - 15, 1988. A discussion of the incident can be found in the 1988 BNL SER. ${ }^{10}$ In 1990, cesium-137 concentrations were still four times pre-1988 values.

The gross beta data for the STP effluent discharged to the Peconic River also remained influenced by the residual leaching of cesium-137 from the June, 1988 release. In 1990, gross beta concentrations at Location EA were essentially 1.6 times the influent concentrations. Cesium-137 concentrations in water collected from Location EA were 25 times the concentration found in the clarifier effluent which is consistent with 1989 data. Strontium-90 concentrations at Location $E A$ were about 1.5 times the concentrations that were detected at Location DA. Although elevated, these concentrations at Location EA did not result in any violation of the SPDES permit. Finally, strontium-90 data are reported here and throughout the report only for the first three quarters of 1990. Fourth quarter 1.990 samples were not analyzed in time for inclusion in the 1990 report but wil1 be included in the 1991 report. If the BNL Administrative policy dose criteria of $4 \mathrm{mrem} / \mathrm{yr}$ were used for comparison, daily ingestion of water discharged by BNL to the Peconic River would result in an annual dose of 0.2 mrem $(0.002 \mathrm{mSv})$ or $5 \%$ of $\mathrm{BNL}^{\prime} \mathrm{s}$ current discharge policy. 


\section{Gross Beta Concentration Data Sewage Plant and Peconic River}

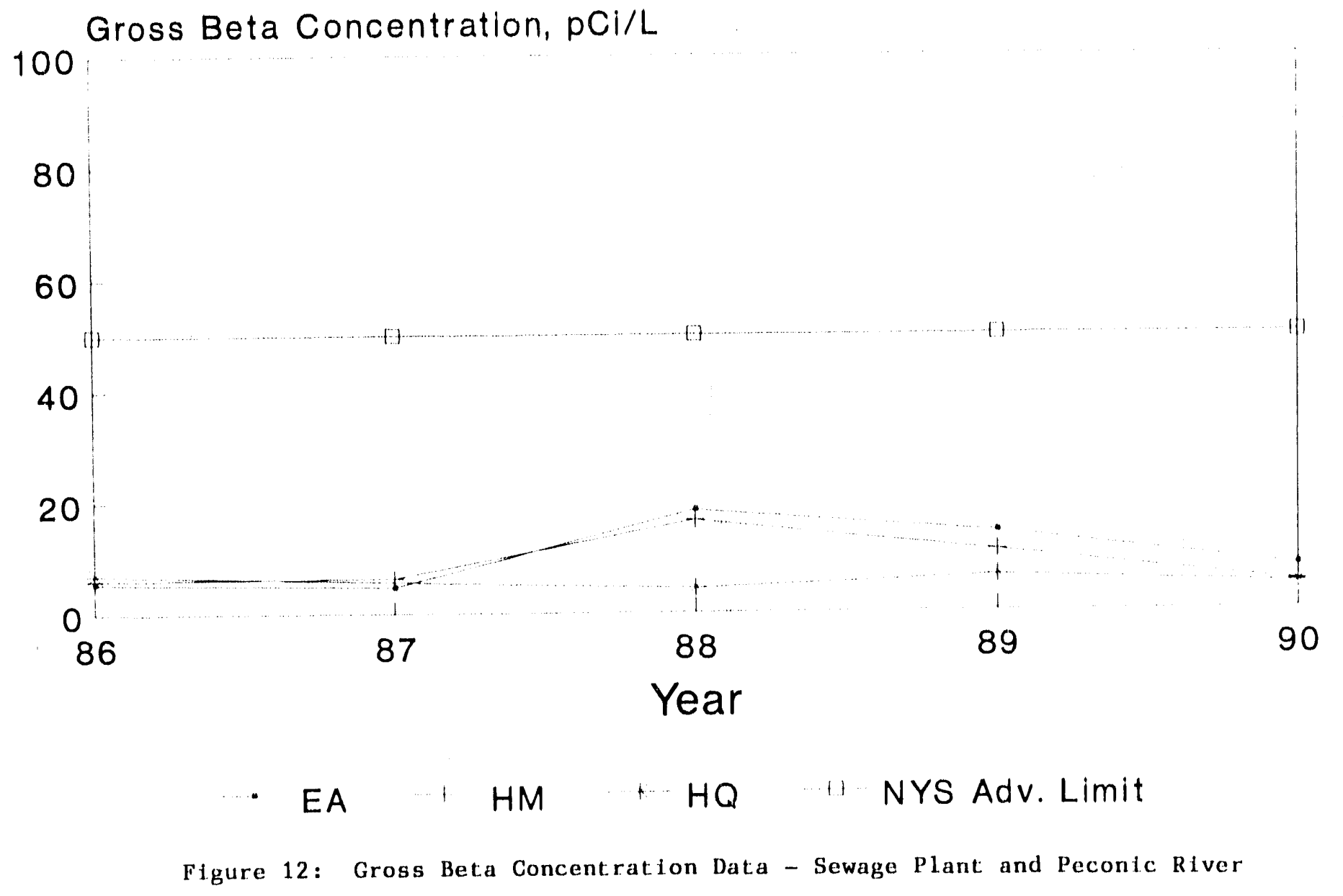




\section{Tritium Concentration Data Sewage Plant and Peconic River}

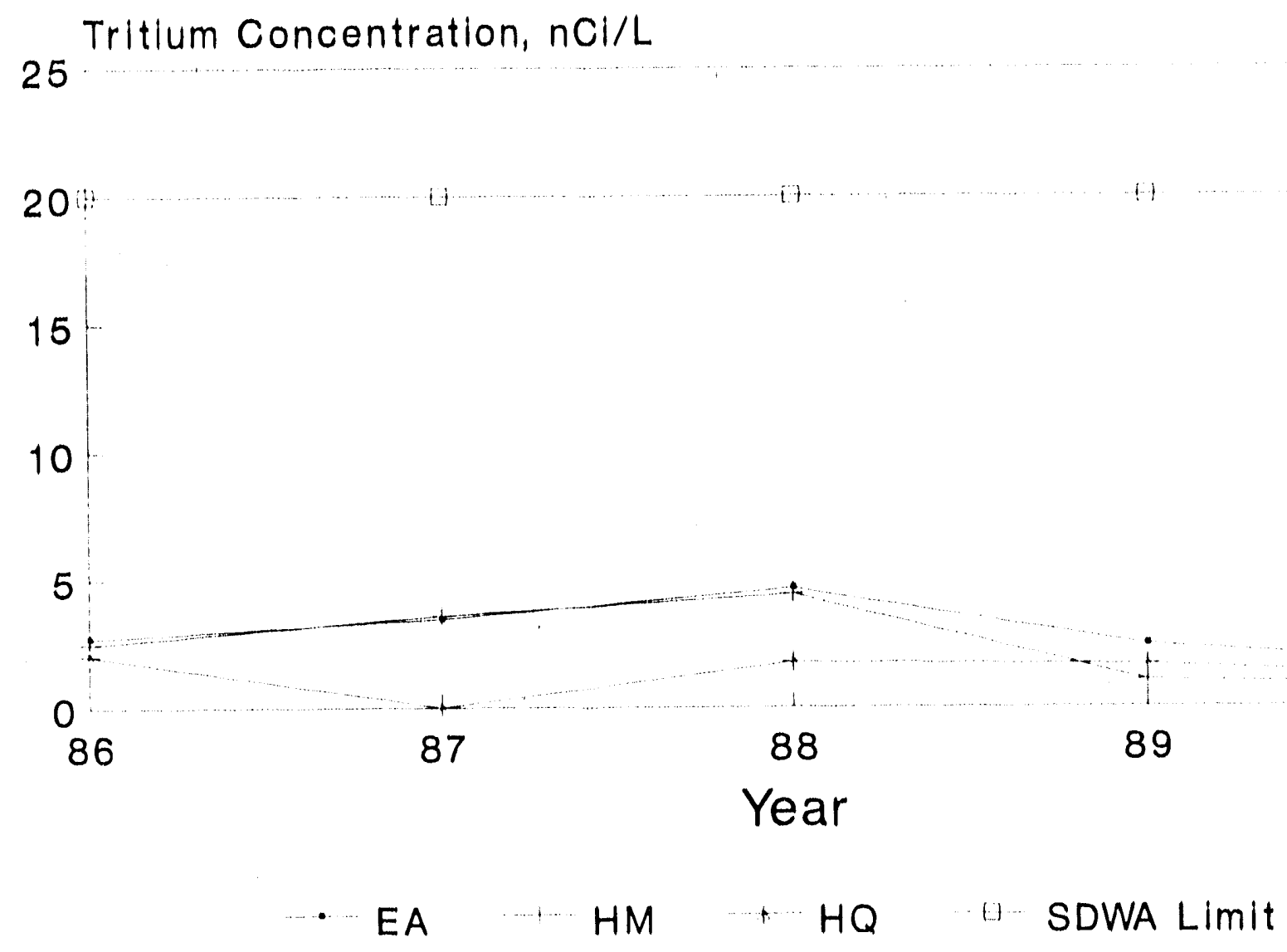

Figure 13: Tritium Concentration Data - Sewage Plant and Peconic River 


\section{Tritium Activity Discharged To The Peconic River From BNL}

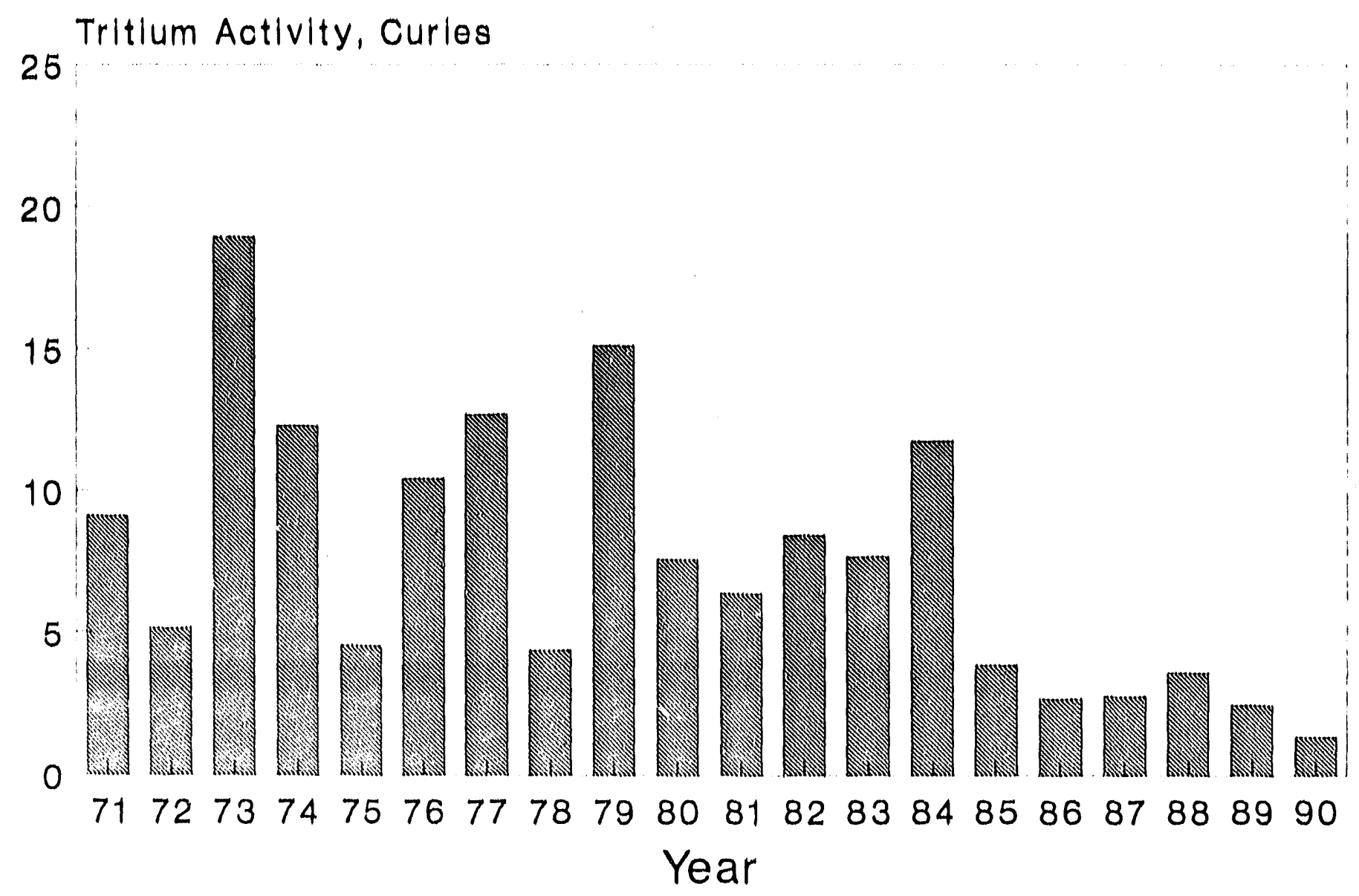

Figure 14: Trittum Activity Dtscharged to the Peconfe River from BNL 1971 to 1990 


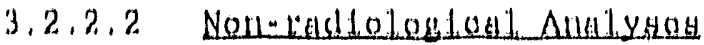

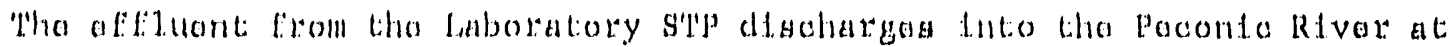

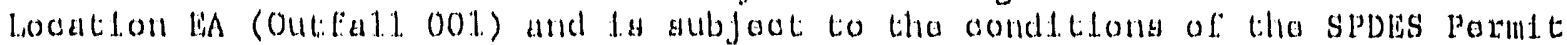

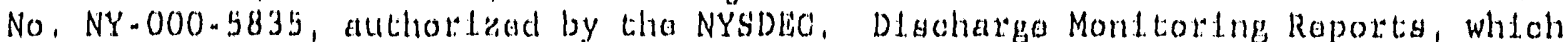

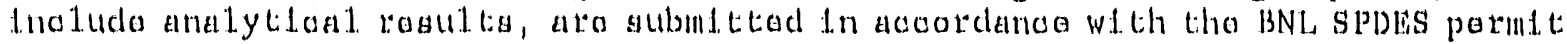

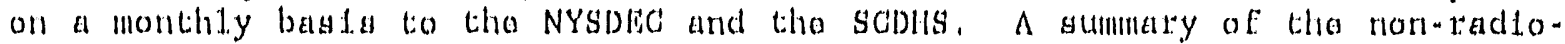

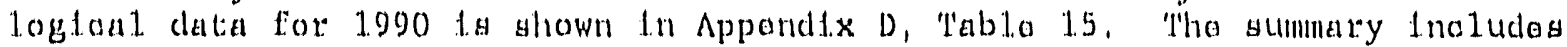

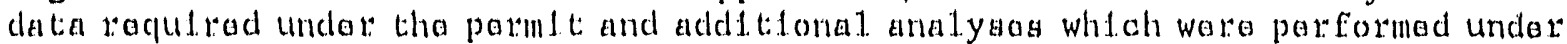

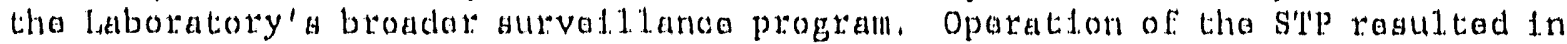

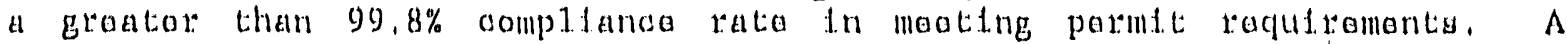

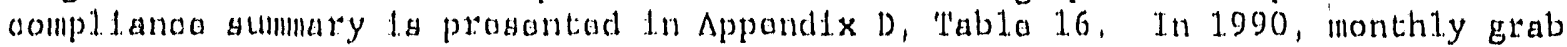

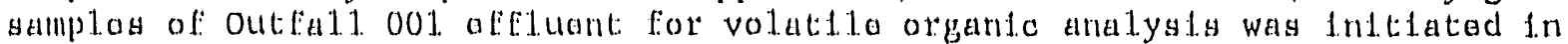

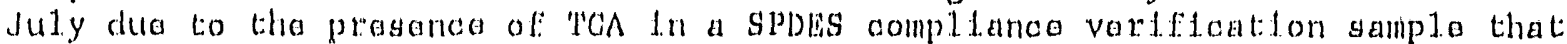
was collaotod In Maroh, 1990 by Now York Stata, Stx months of grab samplos colloctad at approxlmately 0930 hours clurting tho fitest woak of aach month heava

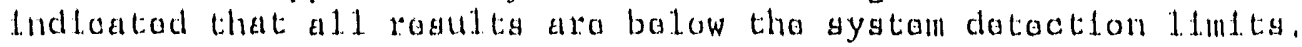

Flguras 1.5 through 2.3 preasont the maxtmum monthly oonontrations and the avarage loading of coppor, lron, load, sllvar, and zino, plottod along with the obsarvad condantrations ato tha curront: SPDES permit 1.ind t:s and the proposed

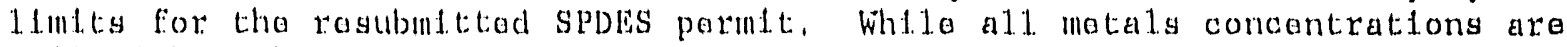
we11. wlthin the oxlattng permit condtitons, the proposed rovised SPDES permit. would astablish lower accoptable relase conoentrations, In the cases of copper and afne, the proposad discharga lifults on allowad relaases could necessitate strtetor sourca control in order to assure compliance. In addition, in order to demonstrate complance with the proposad deschargo limtes for load and silver,

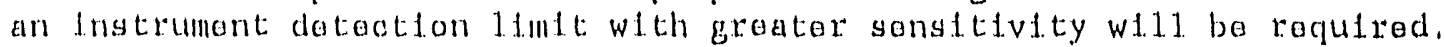

\section{$3,2,3$ Becharge Bestng}

Figure 24 doptcts the locations of BNL recharge bastns within the physfea 1 complex. An overall. schamate of water use at the Laboratory dy shown in Figure 25. Aftar use in "once through" hent: exchangers and process cooling, approximataly 6,78 inl11.10n 11 terg per day (MLD) of water was returned to the aquefor: through on-ste recharge bastrs; 2,04 MLD to Basin HN (Outfa11. 002) locatod about 610 in northast of the AGS; 4.13 MLD to Basin HO (Outfa11 003) about 670 III east of the HFBR; and 0.41. MLD to Bastn HP (Outfa11 004) located 305 in souch of the MRR. Rocharge Basins HS (Outfall 00'j) and HT (Outfal1 006) recolvo a total of about: 0.20 MLD. Discharge of cooling water to recharge basin 110 was roduced from 1989 levels because the HFBR did not operate in 1990. The recharge volume to Bastn IIP is a factor of ten lower than in 1.989 because socondary cooling for the MRR was supplled by tha potable water system for six months and the MRR did not: operate for three months.

A polyelectrolyte and dispersant was added to the AGS cooling and process water supply to koep the amblent: fron in solution. of the total aGs pumpage, approximately 2.04 MLD was discharged to the HN Basin, and 3.4 MLD to the HO Basin. The HFBR secondary cooling system water rectrculates through mechanfcal. coollng towers and was traated with inorgante polyphosphate and mercaptoben. zothlozone to control corrosion and depostiton of solids. The blowdown from this system (0.77 MLD) was also discharged to the HO Basln. The MRR secondary cooling water $(0.41$ MLID) was adfusted to a neutral. ph prior to use and thon discharged to the MRR sump as shown In Figure 24. Cirab samplos were collected at all rechargo basins for water quality analys as as part of the routine EM program. 

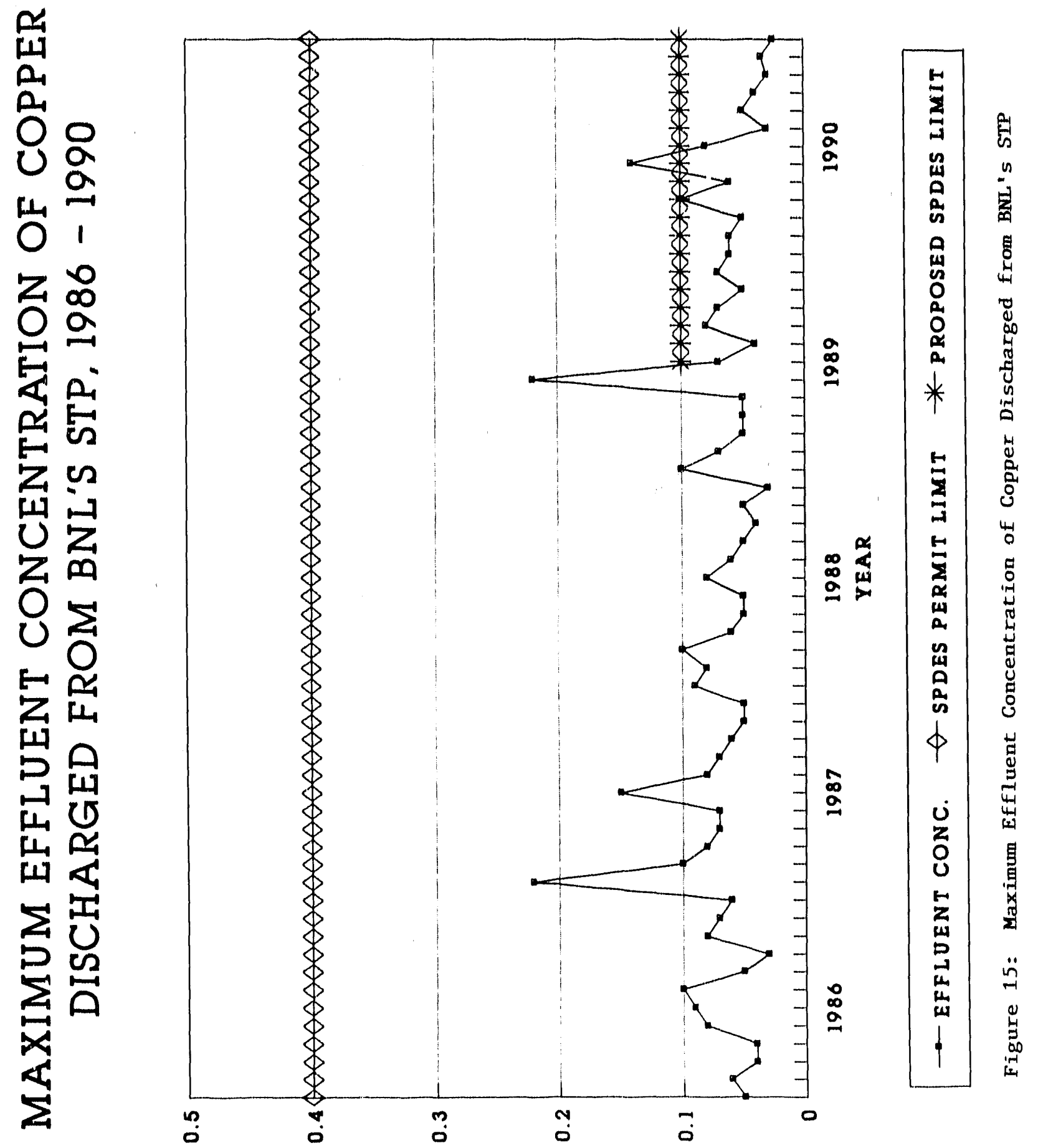

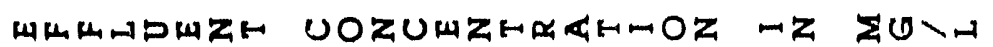




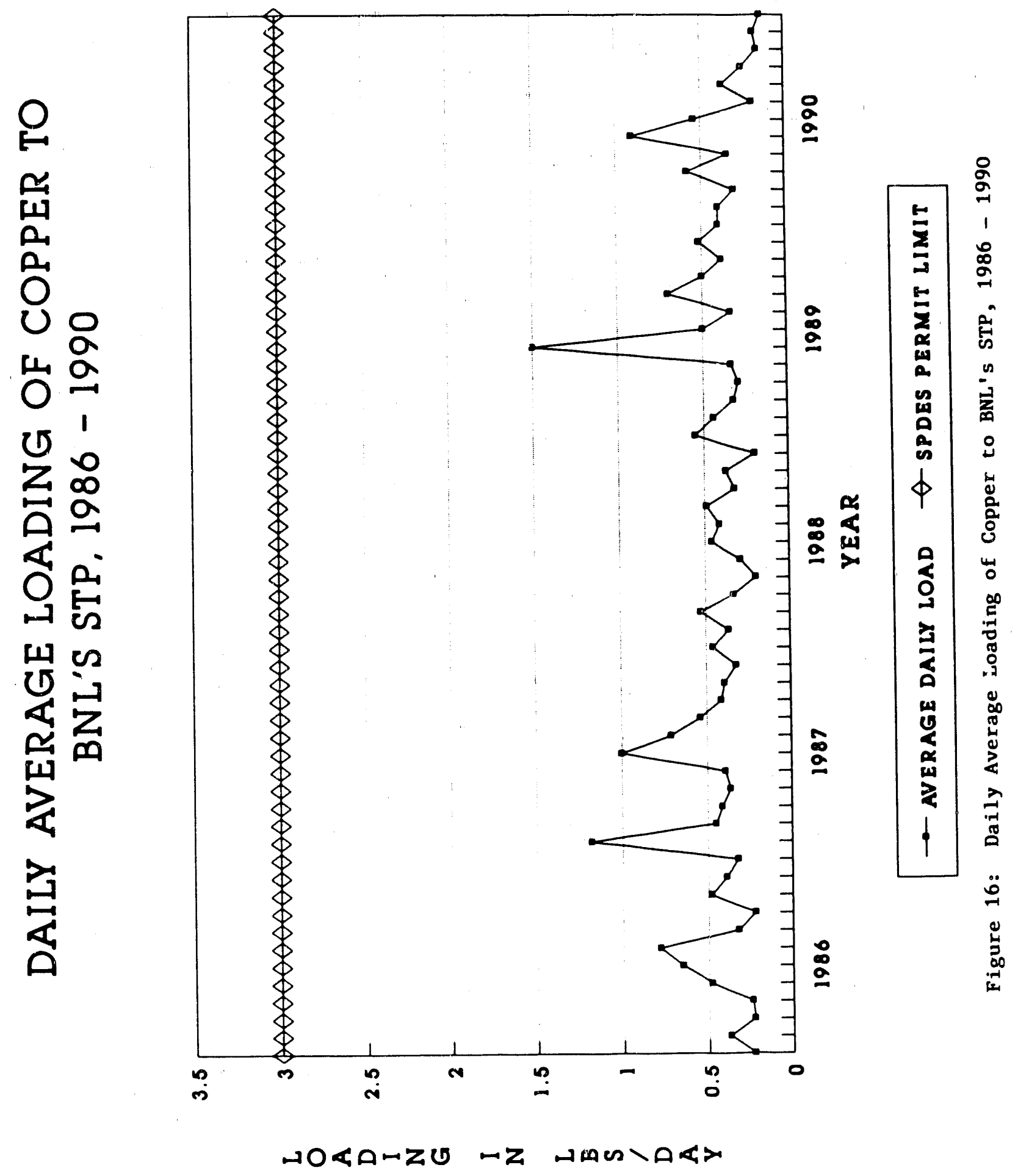



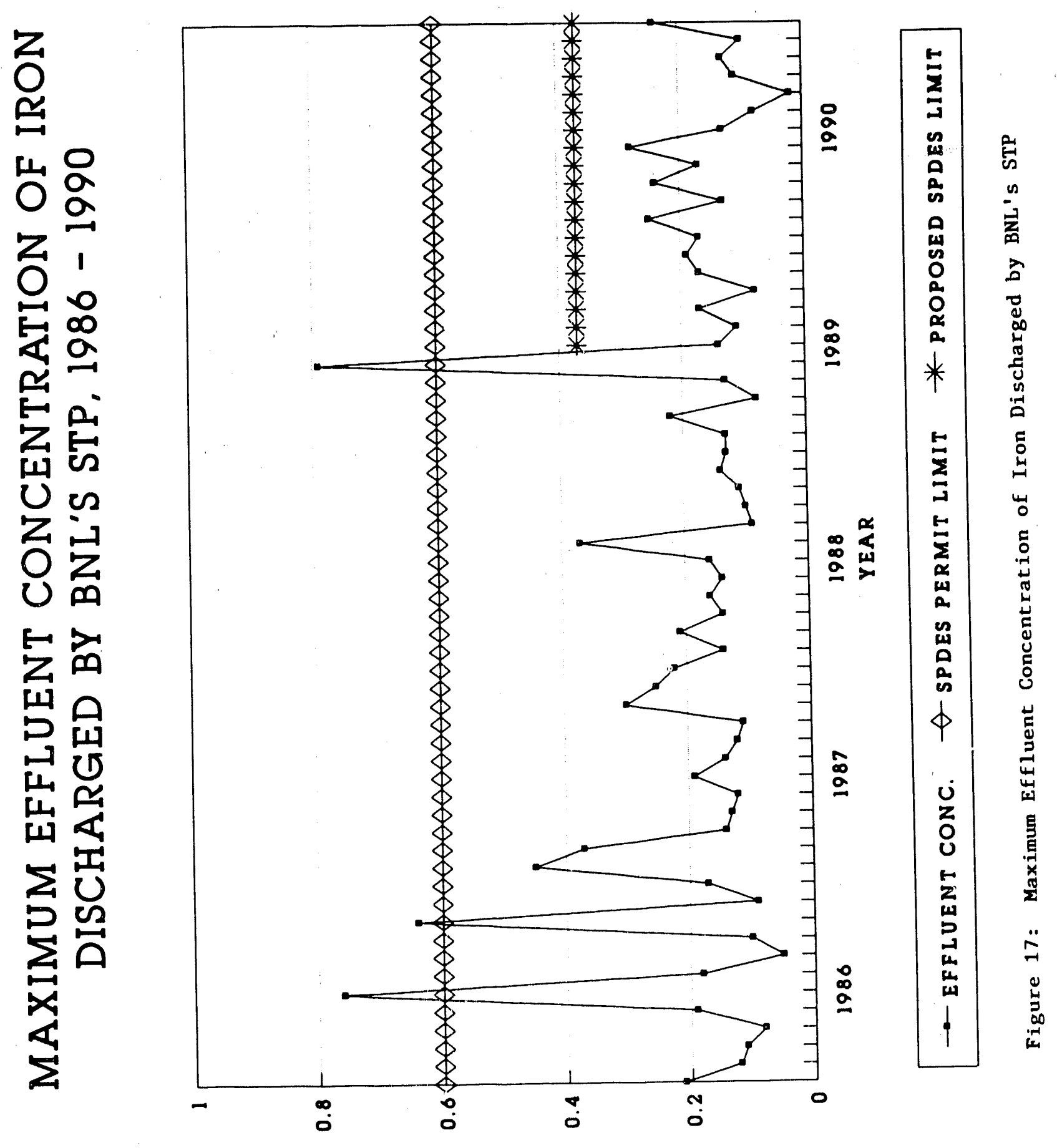

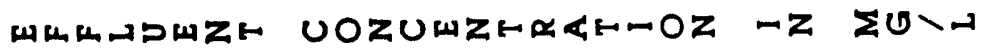



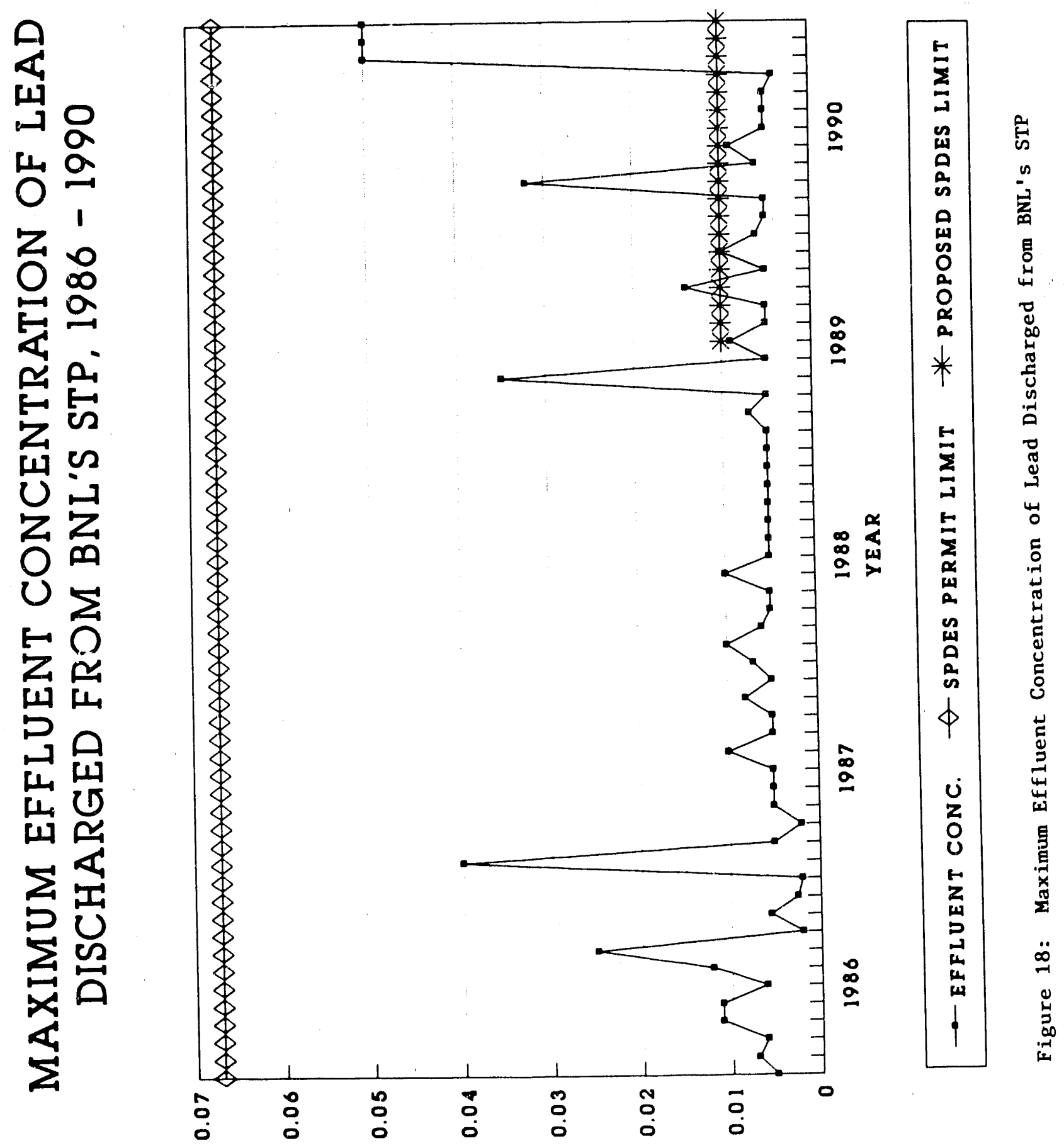

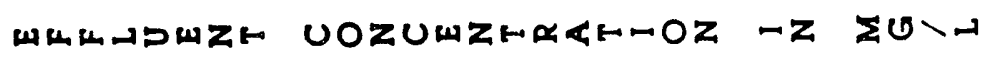




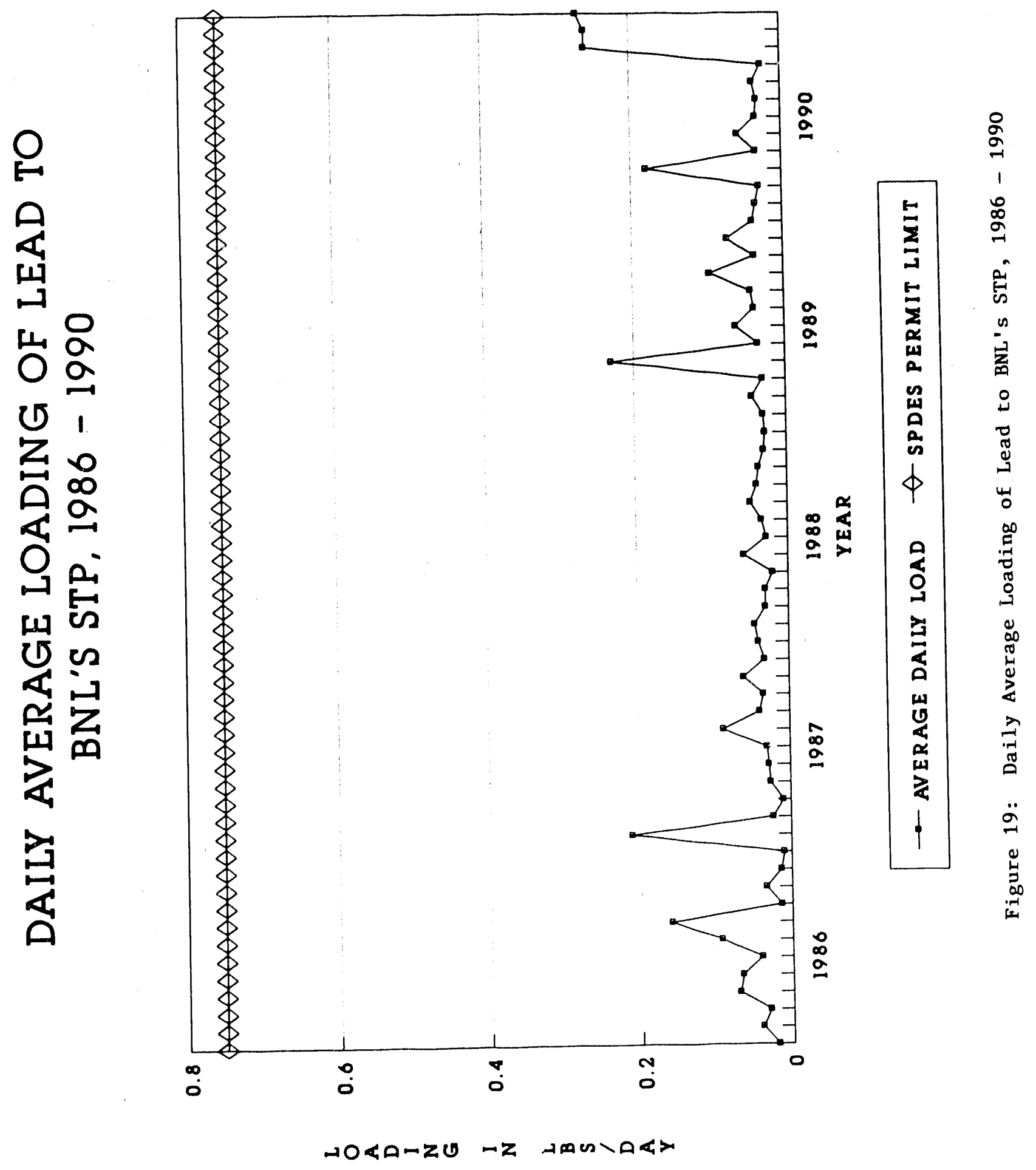



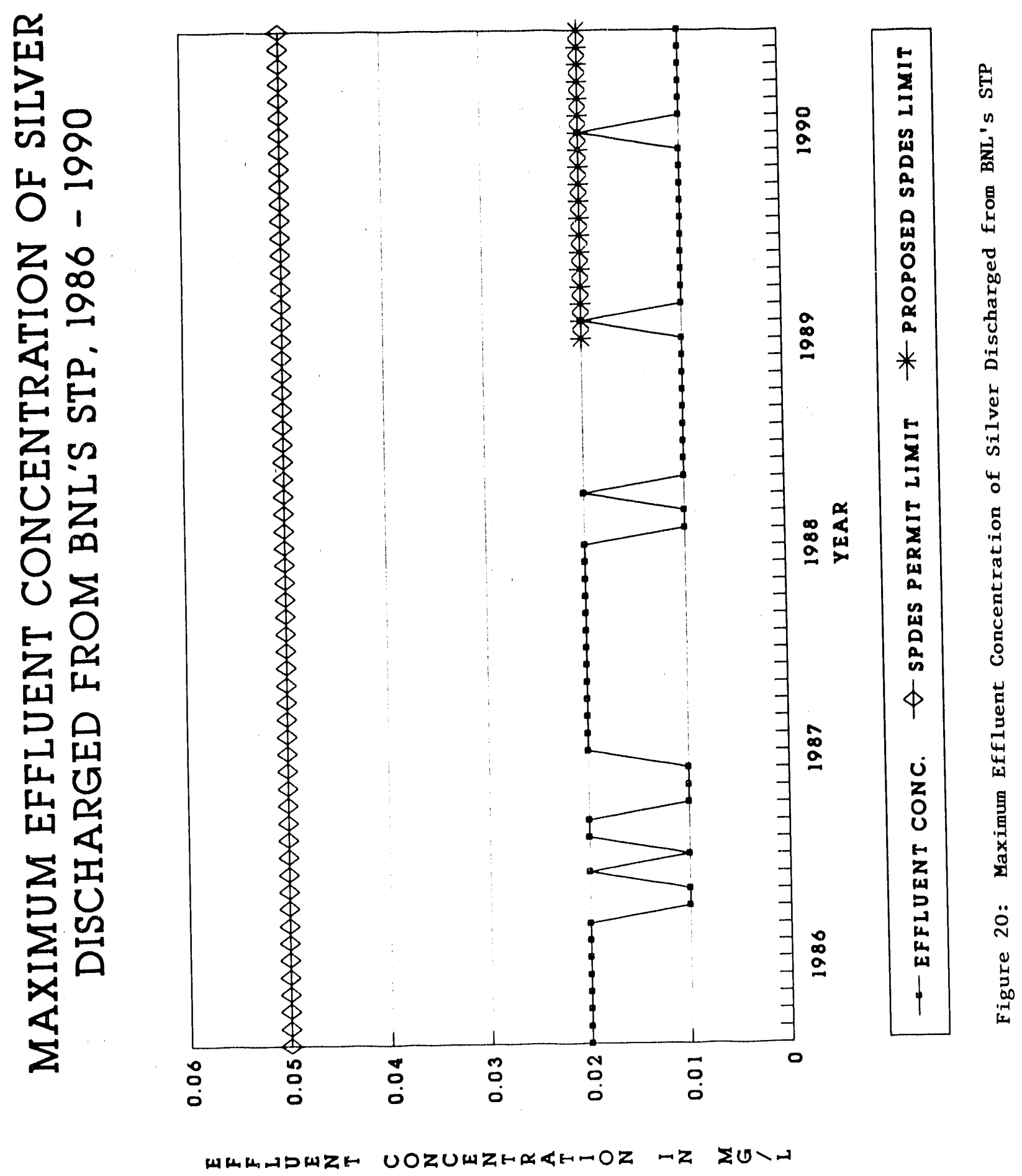


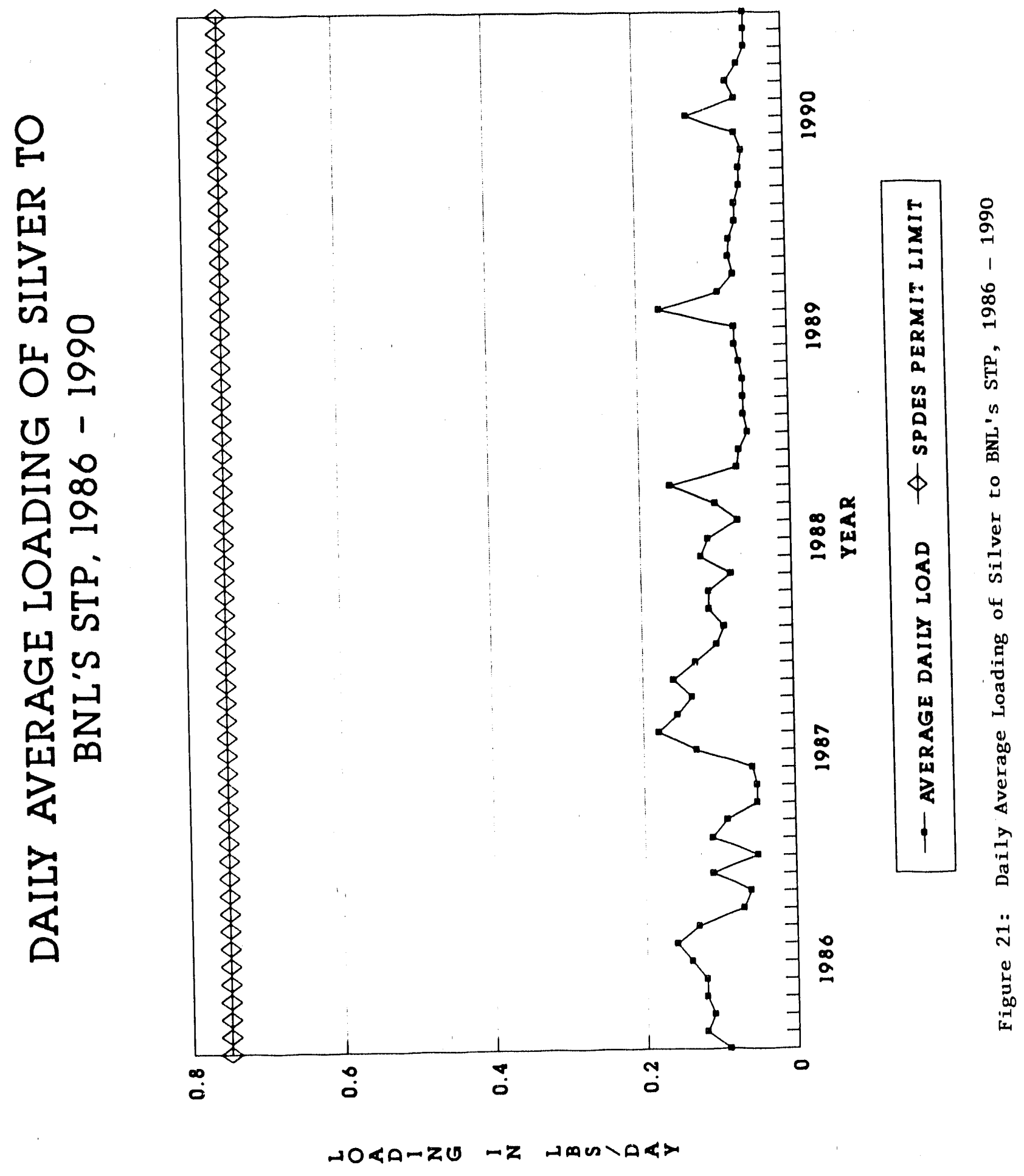



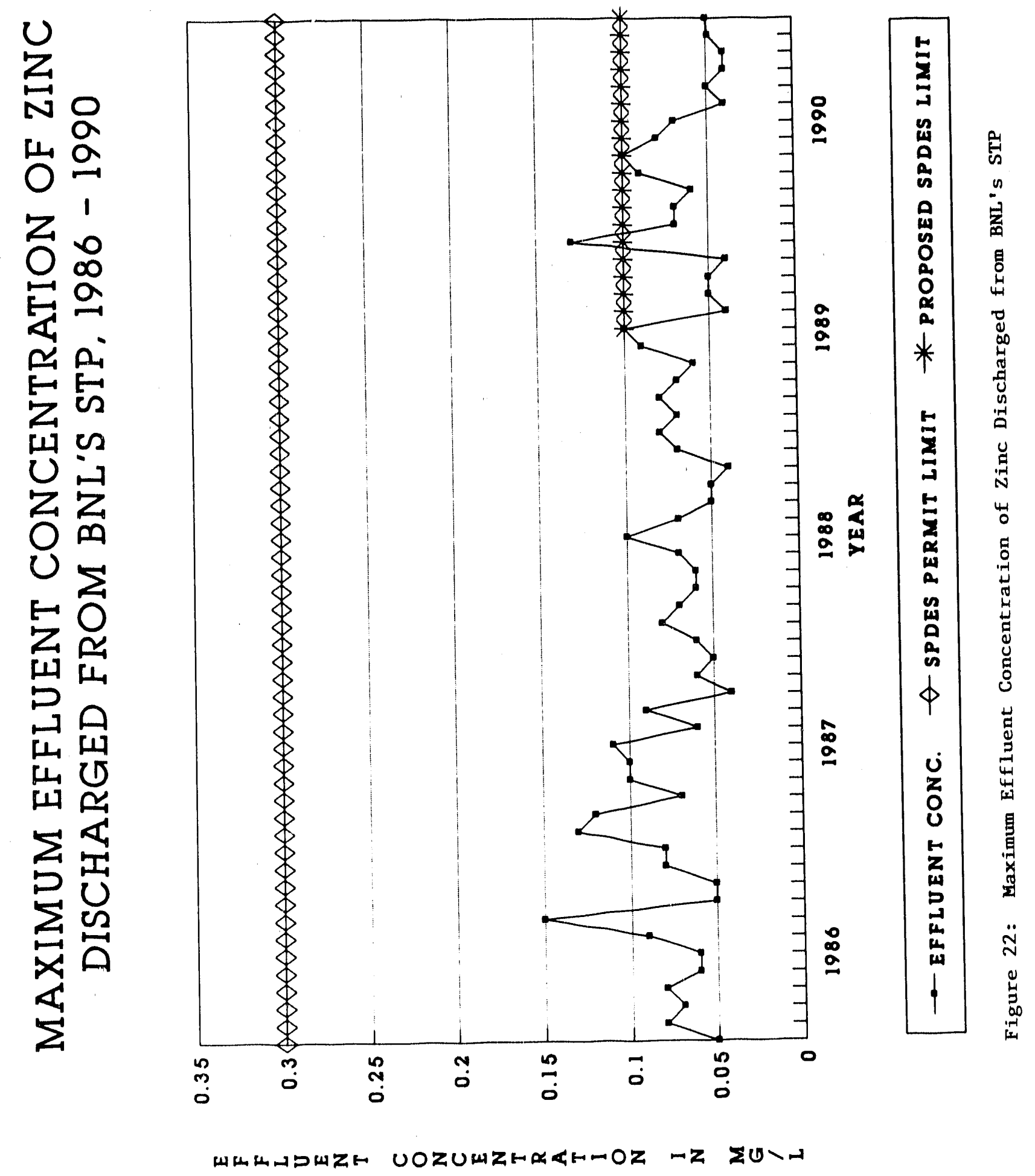


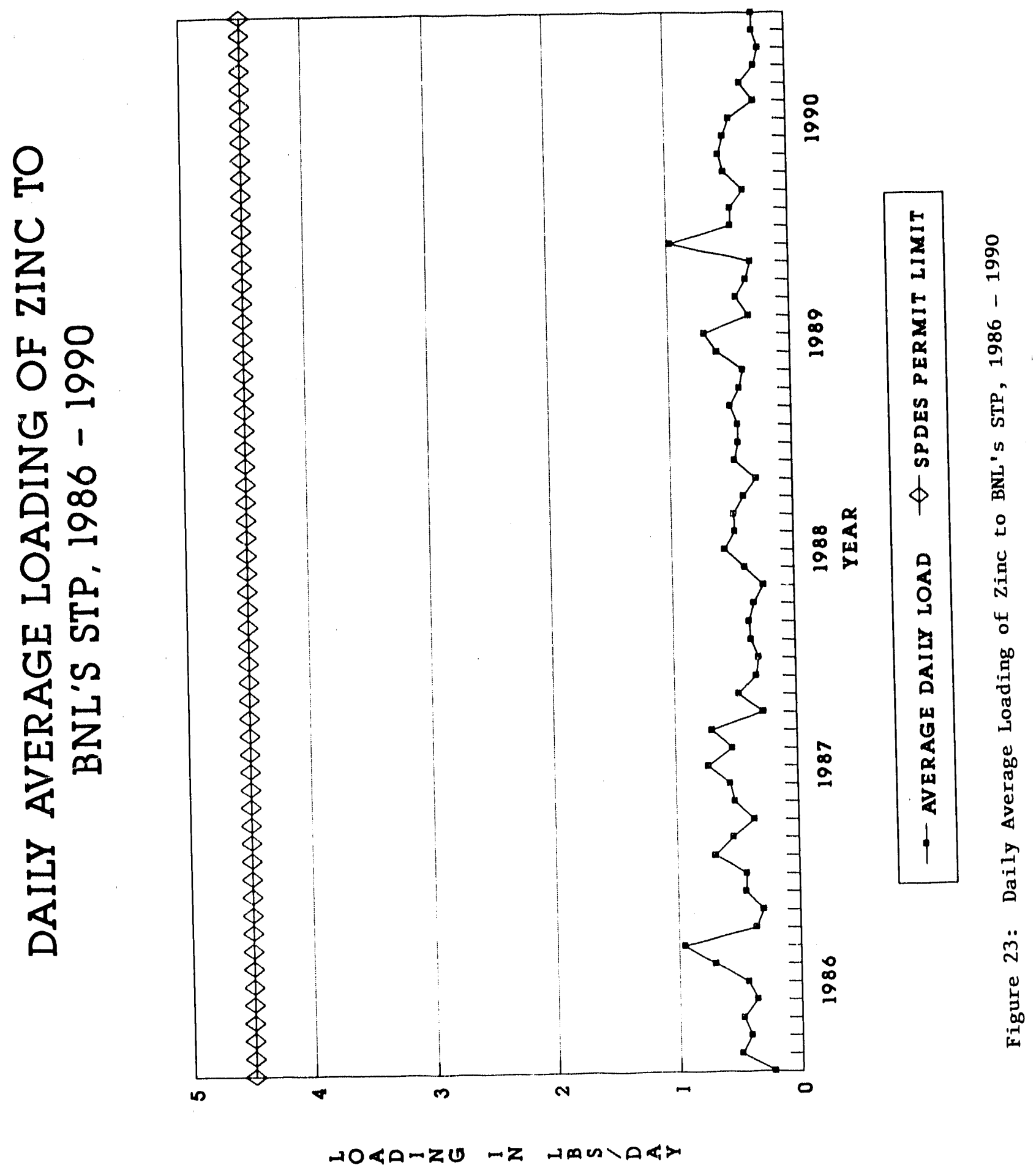




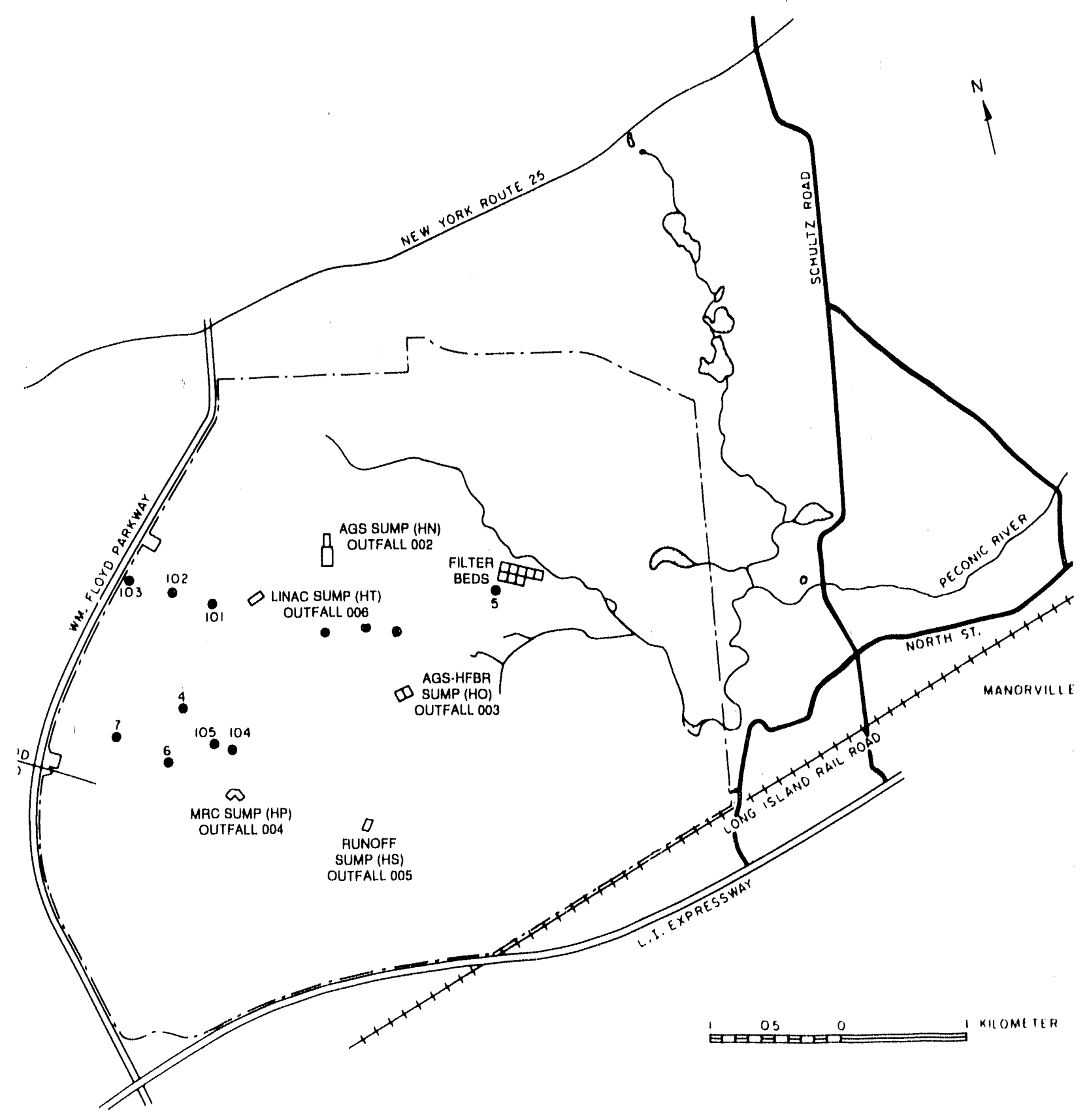

Figure 24: On Site: Potable and Supply Wells and Recharge Sumps 


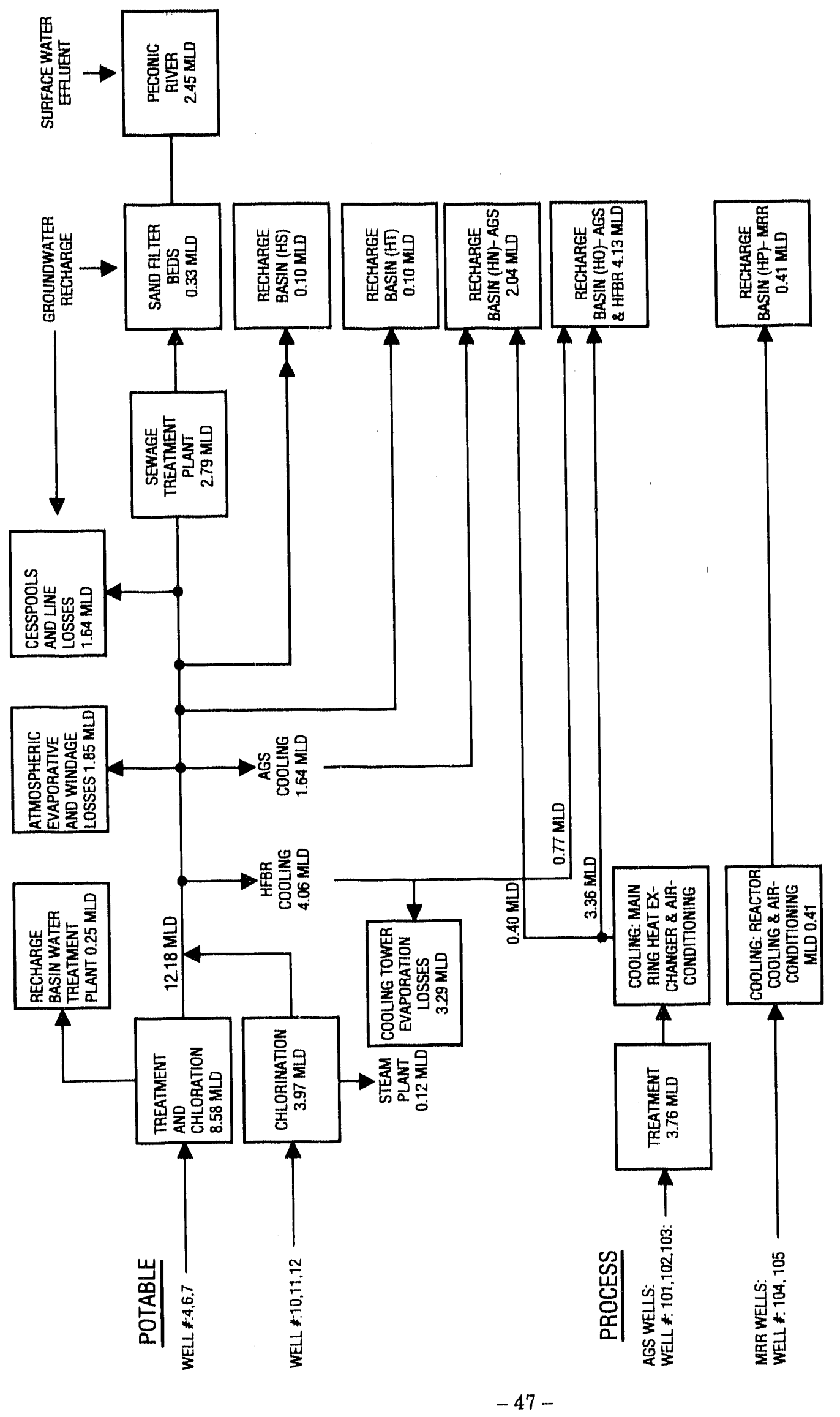

员 


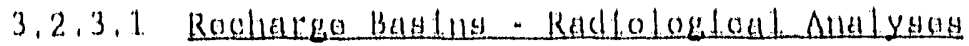

Radlologleal rasules for rachargo basto anmplas aro roportod In Appondex

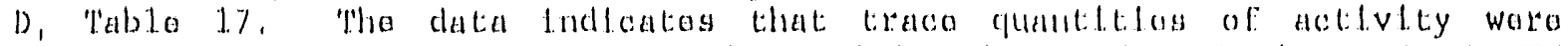

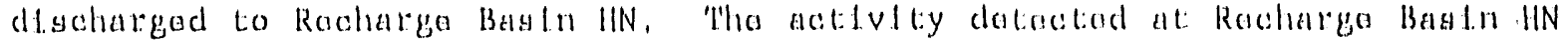

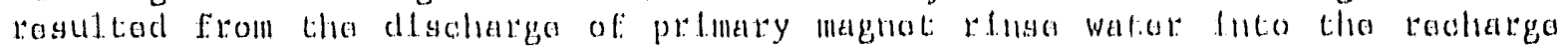

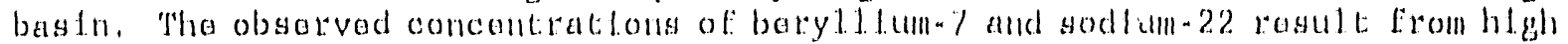
anorgy partolo fntaractong in tha coolting watol at both tha AGs and Linde

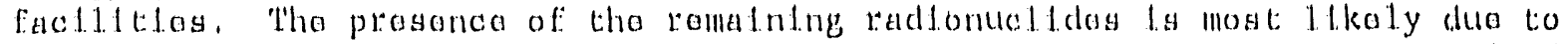
activation of fachlity componentes and subsoquent corroslon. No samplas contalnad strontlun-90 abovo amblant lavols and for virtually all samplas the trltelum concontration was at or lass than tha systan MISL, All concontrations datadiad

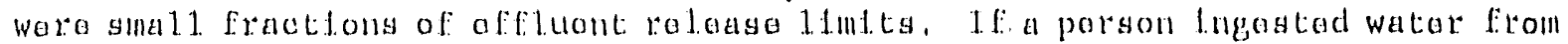
Sump IIN as the solo sourca of drelaklng water for ono yatr, thes would rasult in a committed effective doge equlvalont of $10 \mathrm{sg}$ than $0.0 \mathrm{j}$ mrem $(0.0005 \mathrm{~ms} \mathrm{v})$.

\section{3,2.3.2 Rachargo Baselns - Non-radlologloal Analysas}

In 1990, approxtmatedy 6.8 MLD of water wora dlsohareod to tha rochatge bastns. Tha BNL SPDES peranf raquiros that racords bo malutalnad of the pll and the quantity of water dischargad to thase bastrs. 'The pll of thes water ranged betwoon 4.8 and 8.1 . Theso valuas are outstede the dischargo $1.1 \mathrm{mit}$ t. of 6.5 to 8.5 but consigtent with ground water obgervations throughout the sito and obgarved ranges of pH in preciptation. I'hts last observation ts fmportant bacause most recharge bastn samples are collectad from tho standlne water in the basin which can be a mixture of prectptation and process watar. The resultes of solected water quality parameters are presented in Appondix D, l'abla 18 . All valuas wore whith the NYS DWS.

Water discharged to recharge bastns was also samplod and analyzed for meta1s, The results of theso analyses are prosented in Appondix D, Table 19. Although discharges to rochargo basins typladly met NYS DWS, olovated fron concentrations wero observed at Recharge Basins HN (Outfal1. 002), Ho (Outfal1 003), and HS (Outfall 005), Recharge Basins HN and llO rucolve most of their water from AGS pumping wolls where no iron removal is performed on ground water. Recharge Basin HS recelves prodontnantly ralnwater run-oft and a 1 int ted amount: of processed cooling water.

Collection of grab samples from the recharge basins for VOC enalyses was intetated in 1990. Analytical results are presented in Appendix D, Tables 19A and 19B. No VOCs were detected wt th the exception of chloroform, which was found in concentrations ranglng from 2 to $5 \mu \mathrm{g} / \mathrm{L}$. The NYD DWS standard for this compound is $100 \mu \mathrm{g} / \mathrm{L}$.

\subsection{Envtronmental Measuraments and Analyses}

\subsubsection{External Radiatton Monftoring}

Dose-equivalent rates from gamma radtation at the site boundary, including natural background, weapons test fallout, and that attrlbutable to Laboratory activfties were determined through the use of $\mathrm{CaF}_{2}$ :Dy TLDs. ${ }^{30,31}$ The locations 


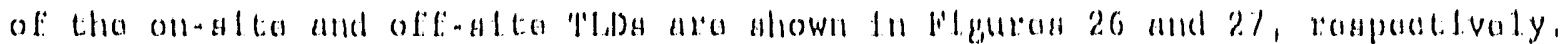

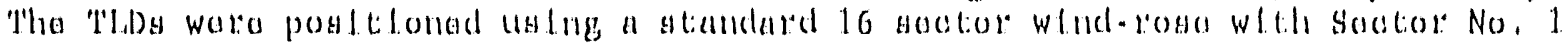

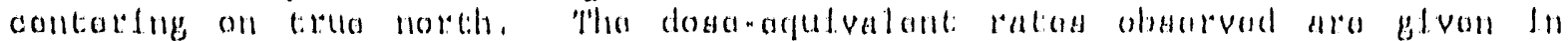

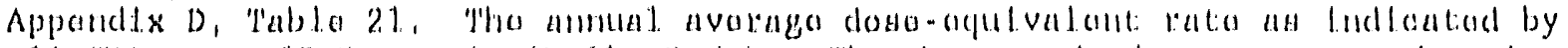

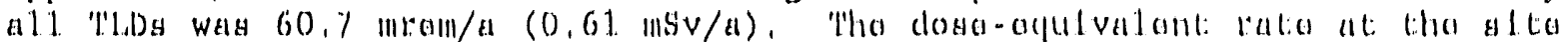

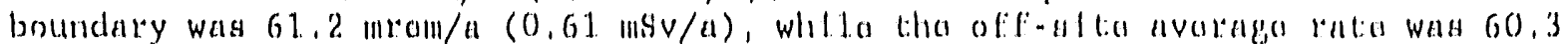

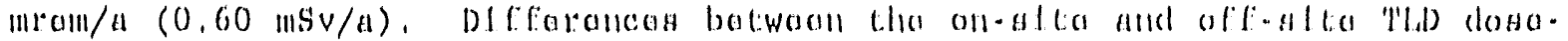

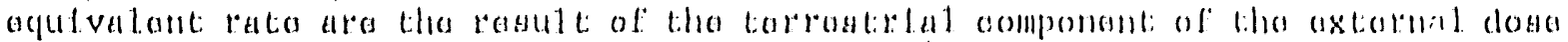

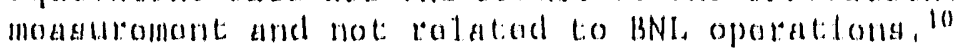

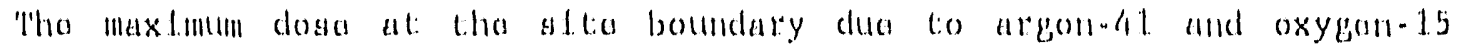

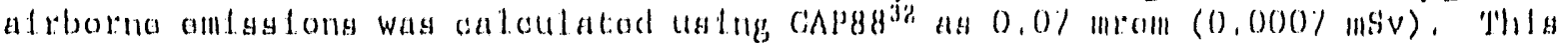

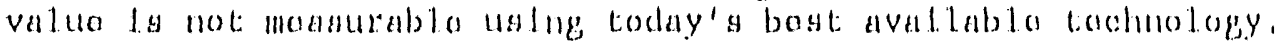

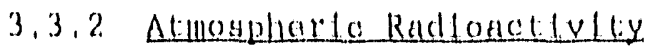

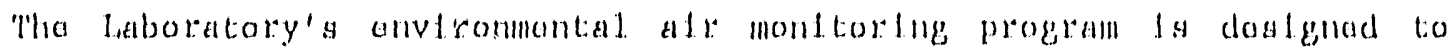

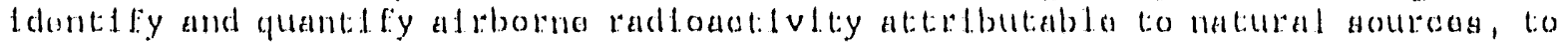

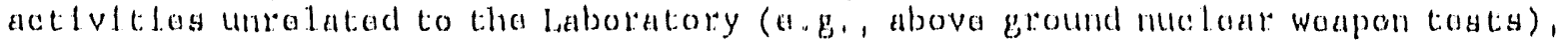

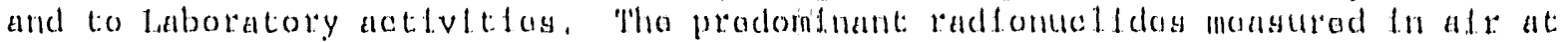

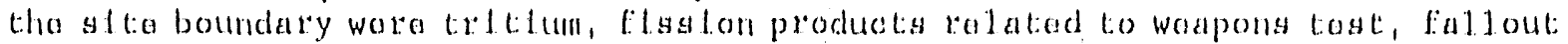

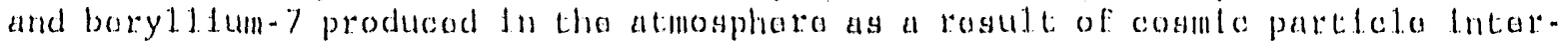

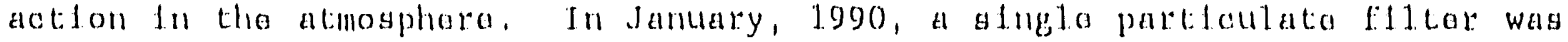

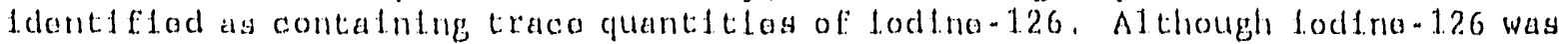

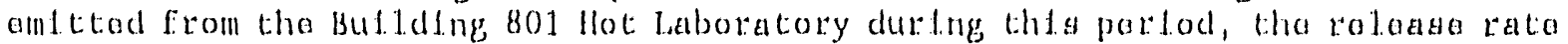
was at normel. lovals. Furthormora, lodtno la mormally not datactod on particulato filtars wlthout a sientficantly largar fraction balng adsorbad onto the charcoal filtar that is prosant In the sampline trala. Sourca carm Information and supplomantal anviromental data do not support this rasult as valid. Consaquantily, tha datuin $1 \mathrm{~s}$ consldorad as an outllar. It $1 \mathrm{~g}$ presontad fo the tables but not usod to the assessment of facllity fimpact.

\subsubsection{Irftulum Analygogs}

Sampling for trltham vapor was performad at stx difforont on-glto stations (as shown in filgura 9). Location 6'l had a cluplloata sampla trafn all yoar (Identiflad as G'l't and G'l'? In Appondlx D, 'l'ablo 22.) and ale samplas were

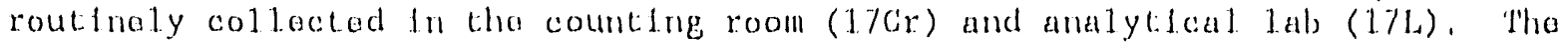
method of sampling was tha collaction of water vapor by drawing a gtraan of afr: through silfca gel cartridgos. The data collocted from thoso stations are presented in Appondle D, Tab1a 21. Tho maxhum annual avorago tritfum concentration at the sito boundary was observed at station $1.6 \mathrm{f}^{\prime}$ and was $7.9 \mathrm{pc} / / \mathrm{m}^{3}$ $\left(0.3 \mathrm{Bg} / \mathrm{m}^{3}\right)$. This afr concentration would result in whole body doso from the Inhalation and submerston pathways of 0.006 mrom (0.00006 mive) By comparison, the National Councti on Radlation Protection (NCRP) publication 9l recoimends that: 1 mren $(0,01 \mathrm{mSv})$ is a dose which is bolow regulatory concorn, ${ }^{33}$

The atrborne tritlun concentrations measured outs ide Bullding 535 (Location 20't) reflect anblent alr concentrations in tho central part of the Laboratory site. Tho annual average atr concentration at: this 10 cation was $8.7 \mathrm{pct} / \mathrm{m}^{3}$ $\left(0.32 \mathrm{~Bq} / \mathrm{m}^{3}\right)$ and would rapresant a dosa of 0.002 . mrom $(0,00002 \mathrm{mSv})$ to the typteal. BNL amployes. 


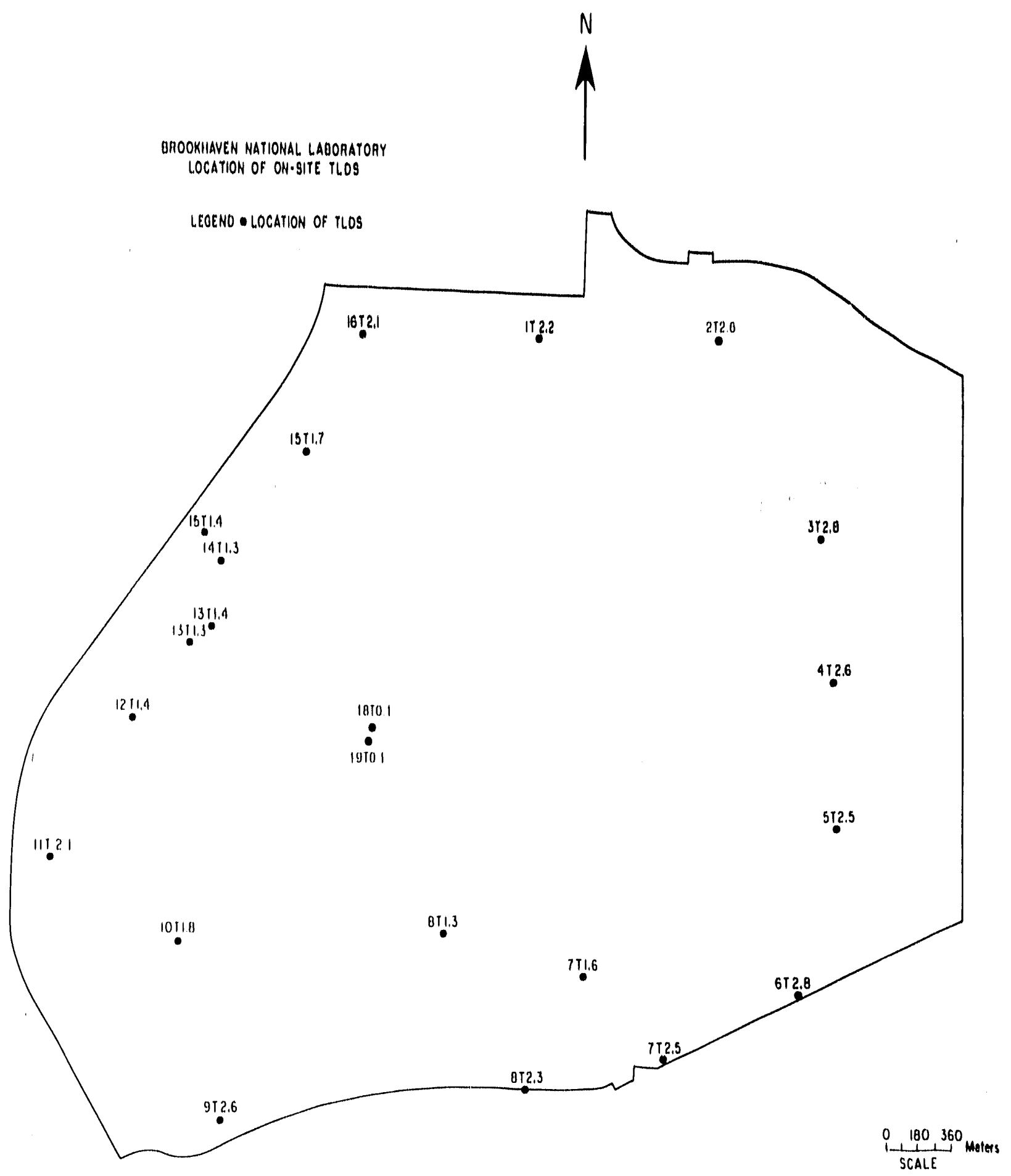

Figure 26: Brookhaven National Laboratory Location of On-Site TLDs 


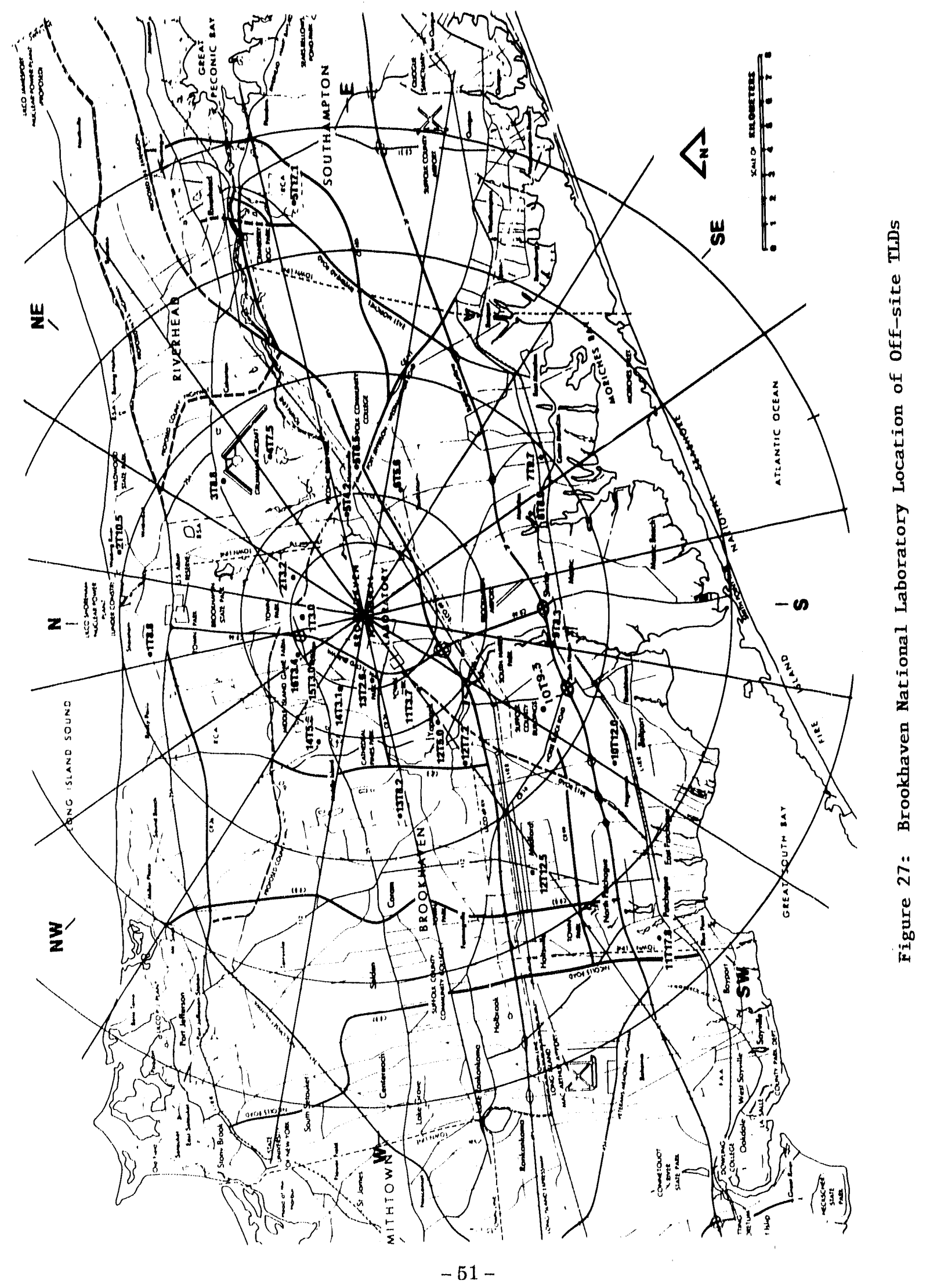


As part of the response to the DOE Tiger Team Audit, ${ }^{34}$ the impact of down draft at the $100 \mathrm{~m}$ stack was incorporated into the tritium source term in an effort to have the modeled data be more comparable to the measured site boundary tritium data. This was nerformed in 1989 and resulted in good agreement between the data sets. In 1990 , tne comparison of modeled versus measured data indicates that measured data results in a calculated site boundary dose of about ten times the value calculated by CAP88 using actual meteorological data and measured effluent releases. Having made reasonable correction to the model for tritium sources and knowing that the model accurately predicts gaseous plume concentration and dose, the issue of non-comparable measured versus predicted tritium concentration and dose now centers on the ability to measure tritium at the predicted air concentration considering the low air sample volume required to collect the sample and the present practice of processing environmental and effluert samples in tie same work space. The MDL of the sampling system for tritium, assuming a $200 \mathrm{cc} / \mathrm{min}$ sample rate, processing in a tritium free environment and counting in an ultra-low background counter, is $0.2 \mathrm{pCi} / \mathrm{m}^{3}(0.008$ $\mathrm{Bq} / \mathrm{m}^{3}$ ) which corresponds to a dose of $0.00015 \mathrm{mrem} / \mathrm{yr}(0.0000015 \mathrm{mSv} / \mathrm{yr})$. These air concentrations and dose rates are comparable to the CAP8 8 predicted values. Since the sample flow rate and the method of counting used by BNL are equivalent to those needed for the projected sensitivity, the issue of better model/measured agreement revolves around the processing of environmental tritium air samples in the same area as effluent tritium samples.

The presence of tritium in the sample processing area, as evidenced by air concentration in the Building 535 Counting Room and Analytical Laboratory, is certainly the most obvious reason for the inability to obtain better agreement between modeled and measured tritium data. The resolution of this issue, processing effluent and environmental samples in the same work area, is being addressed as a response item to the Tiger Team findings.

For the foreseeable future, site perimeter monitoring will continue to be used as a method to monitor for potential large releases and provide an upper bo: ndary for both model verification and dose estimates. Compliance verification will be performed using CAP88 and measured source terms plus BNL meteorology.

\subsubsection{Radioactive Particulate}

During 1990, positive displacement air pumps were operated at five on-site monitoring stations (16T2.1, 11T2.1, 6T2.8, 4T2.4, and S6). The sampling media consisted of a $5-\mathrm{cm}$ diameter air particulate filter followed by a $51.5 \mathrm{~cm}^{3}$ canister of triethylene diamine-impregnated charcoal for the collection of radiohalogens. The air particulate samples were collected on a weekly basis (except for Location S6 which was changed daily) and counted for gross alpha and beta activity using an anticoincidence proportional counter. Sample Location S6 gross alpha and gross beta data have higher average values than other sample sites because of the difference in sample period. The air particulate gross alpha and beta data are consistent with 1989 BNL data. However, the gross beta concentrarions are four times higher than EPA values for Yaphank, New York. ${ }^{11-14}$ This is most likely due to differences in methods of sample processing. For 1990, the background suthracted for gross alpha and gross beta analysis by BNL was the empty counter background. Use of an un-used filter paper as the background dramatically changes the result and is responsible for the difference between the EPA and BNL data sets. 
In addition, analyses for gamma-emitting nuclides were performed on a weekly composite of the filter papers and on charcoal filter bed samples that had a sample period of one month. The analytical results for air particulate filters are shown in Appendix D, Tables 22 through 26. Gamna-emitting radionuclides detected on charcoal filters are reported in Appendix D, Tables 27 through 31.

The presence of Chernobyl fallout, weapons test fallout from previous years, and cosmogenically produced radionuclides were detected by gamma spectroscopy at or near the systems minimum detectable activity levels. In January, 1990, what is believed to be an anomalous iodine-126 value was reported for an air particulate filter at Location 16T2.1. If that value is real, a resident at that location of the maximum observed concentration would have received a committed effective dose equivalent of 0.006 mrem (0.00006 mSv) as a result of inhaling the measured concentrations. This dose is below both the $\mathrm{NCRP}^{33}$ and $\mathrm{EPA}^{32}$ level of "de minimis".

\subsubsection{Radioactivity in Precipitation}

Pot-type rain collectors are situated at Locations S5 and 11 (Figure 9). Dry deposition and precipitation samples were collected on a weekly basis. Portions of each collection were processed for gross alpha, beta, and tritium analysis. A fraction of both the precipitation (wet) and dry deposition (dry) samples was composited for quarterly gamma analysis. Strontium-90 analyses were performed quarterly on precipitation samples. The data for 1990 are reported in Appendix D, Table 32 and reflect typical washout values associated with atmospheric scrubbing ${ }^{15}$ and the presence of radioactive particulate resulting from cosmogenic production, nuclear weapons fallout and Chernobyl. These data are similar to those detected by EPA $^{11-14}$ at their Yaphark, New York Monitoring Station.

\subsubsection{Radioactivity and Metals in Soil, Grass and Vegetation}

The results of soil and grass sampling conducted at three locations in the vicinity of the site are shown in Appendix D, Table 33. The results are consistent with data collected in previous years. ${ }^{10}$ No nuclides attributable to Laboratory operations were detected. The observed concentrations represent the contribution of primordial and cosmogenic sources, and weapons test fallout.

\subsubsection{Peconic River Aquatic Surveillance}

\subsubsection{Radiological Analyses}

Radionuclide measurements were performed on surface water samples collected from the Peconic River at six locations; HM, the location of the former site boundary approximately 790 meters downstream of the discharge point; HQ, located approximately $2.1 \mathrm{~km}$ downstream from the discharge point; $\mathrm{HA}$ and $H B$, located approximately $5 \mathrm{~km}$ downstream from the discharge point; HC, located approximately $7 \mathrm{~km}$ downstream of the discharge point; HR, located $21 \mathrm{~km}$ downstream from the discharge point. A control location (Location HH) located on the Carmans River in North Shirley which is not influenced by BNL 1 iquid effluent was also sampled. The Peconic River sampling stations are identified in Figure 28 . Routine grab sampling at both the former site boundary (Location HM) and the current site 
boundary (Location HQ) was conducted three times per week. The locations are equipped with $V$-notched weirs to permit flow proportional sampling and volume measurements. Due to heavy vegetation growth down stream of these weirs, which causes no vertical drop across the weir, volume measurements cannot be performed with the existing equipment. Figure 29 provides a twenty year review of liquid discharge volumes to the Peconic River and flow estimates for the Peconic River on-site. The data indicate that there was no measurable flow at the site boundary between 1983 and 1988. Non-quantifiable flow has existed at Location HM since 1984 due to vegetation growth in the river bed downstream of the weir. Between 1985 and 1988, water levels at Location HQ have been below the conduit which transports water from the BNL site to the weir at Location HQ. As stated earlier, vegetation growth below the weir is now too dense to permit flow measurement using the currently installed equipment. Samples from Locations HA, $\mathrm{HB}, \mathrm{HC}, \mathrm{HR}$, and $\mathrm{HH}$ were collected during the first, third, and fourth quarters of 1990. No samples were collected in the second quarter due to a reprioritization of field sampling team activities associated with presence of the DOE Tiger Team.

The radiological data generated from the analysis of Peconic River surface water sampling are summarized in Appendix $D$, Tables 34 and 35 . The data indicate that gross beta, tritium, cesium-137, and cobalt-60 are present above ambient levels at Locations HM and HQ. Trace quantities of tritium are present out to Location HR. Strontium-90 and cesium-137 are present at ambient levels in all surface water tested.

\subsubsection{Non-radiological Analyses}

Measurements of selected non-radiological water quality parameters were performed at the former site boundary (Location HM). Ancilytical results are presented in Appendix D, Table 36. A pH range of 3.1-7.2 was observed at this location. The results for metal analyses are presented in Appendix D, Table 37. Metals such as silver, cadmium, and chromium were not detected. Copper, mercury, manganese, and lead were occasionally detected at or near the lower limit of detection which is well below the NYS DWS. Iron was the only metal found in concentrations which exceeded the NYS DWS.

In 1990, surface water samples were also collected along the Peconic and Carmans Rivers. These samples were analyzed for water quality parameters. The analytical results are presented in Appendix D, Table 38.

\subsubsection{Aquatic Biological Surveillance}

The Laboratory, in collaboration with the NYSDEC Fisheries Division, has an ongoing program for the collection of fish from the Peconic River and surrounding fresh water bodies (Figure 28). In 1990, fish samples from the Peconic River were collected at Locations EA, HM, Donahue's Pond, and Forge Pond. Control samples were collected from Carmans River and Swan Lake. Specific information regarding the sampling point, distance from the BNL effluent release point, species of fish collected and analytical results are presented in Appendix $D$, 


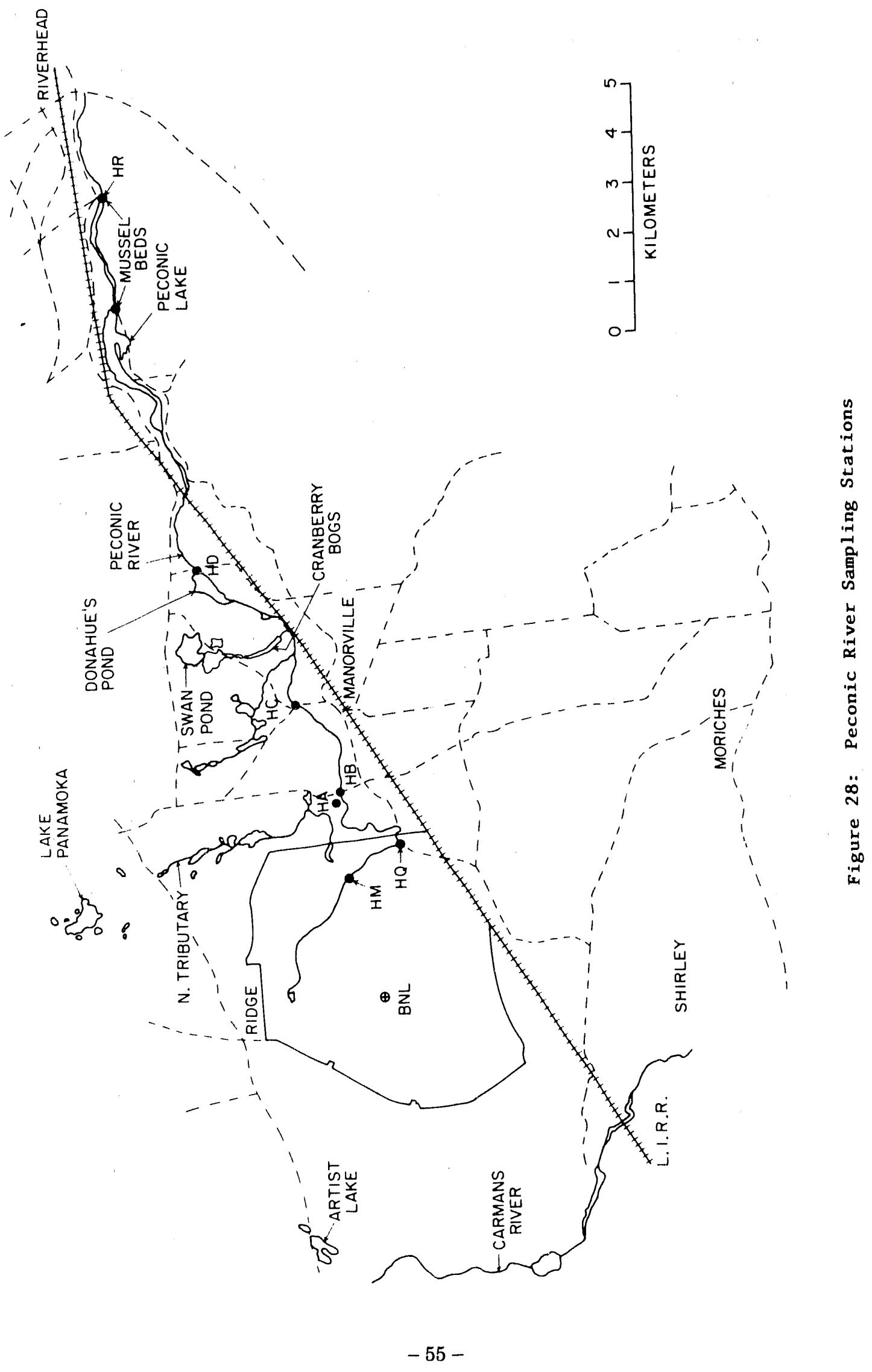




\section{Liquid Flow Data Sewage Plant and Peconic River}

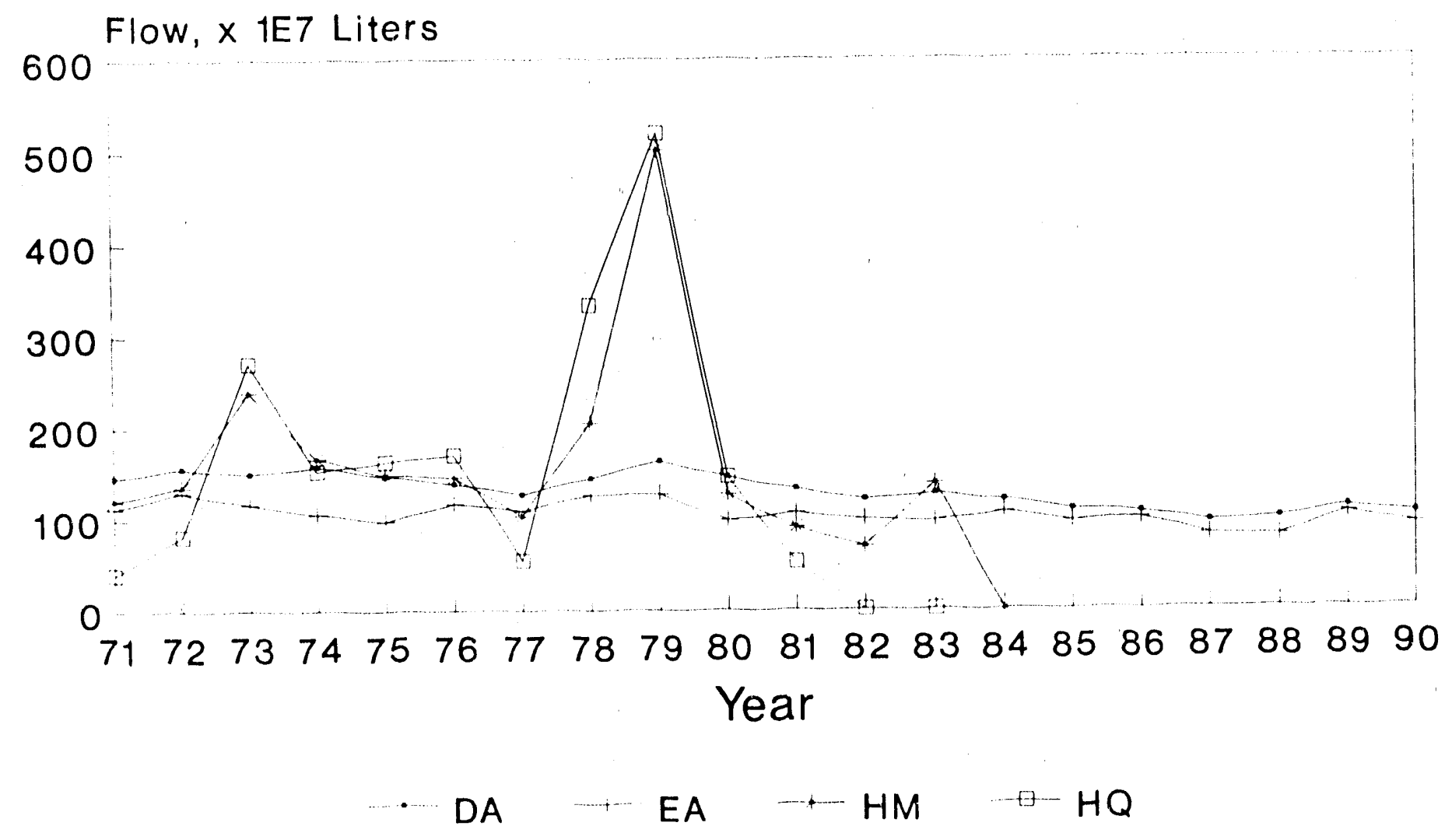

Figure 29: Liquid Flow Data - Sewage Plant and Peconic River 1971 to 1990 
Table 39. In CY 1990 only, gamma spectroscopy analysis was performed on these samples. The Peconjc River fish contained cesium-137 concentrations which ranged from near background levels at Forge Pond (150 - $300 \mathrm{pCi} / \mathrm{kg}$-wet [5.6 - 11.1 $\mathrm{Bq} / \mathrm{kg}$-wet]) to $1,647 \mathrm{pCi} / \mathrm{kg}$-wet $(61 \mathrm{~Bq} / \mathrm{kg}-$ wet) at Location $\mathrm{EA}$. In order to obtain an estimate of the strontium-90 concentrations in fish for 1990 , a strontium-90 to cesium-137 ratio was developed from the data reported in 1989. This relationship was then used to estimate the strontium-90 concentration for use in dosimetric assessment.

The Forge Pond and Donahue's Pond analytical data for cesium-137 indicates that this radionuclide is present in net concentration levels which range from 1.4 to 6.5 times control data. The presence of these levels may be indicative of a BNL contribution to the cesium-137 inventory. Cesium-137 concentrations detected at Locations EA and $\mathrm{HM}$ are clearly related to BNL effluent discharges. The maximum individual and collective dose from the aquatic biological pathway were calculated based on the measured 1990 cesium-137 concentrations and strontium-90 concentrations predicted by multiplying the 1990 cesium-137 concentrations by the 1989 strontium-90 to cesium-137 ratio. Only samples collected off-site were used for this assessment. Based on the methods and results just described, the maximum individual committed effective dose equivalent was estimated to be $0.75 \mathrm{mrem}(0.0075 \mathrm{mSv})$ and the collective committed effective dose equivalent was estimated to be 0.375 person-rem ( 0.00375 person-Sv).

\section{3 .7 Potable Water and Process Supply Wells}

Potable Welis 4, 6, 7, and 12 supplied the majority of potable water for use at BNL during 1990. In October, 1990, Potable Well 4 was voluntarily removed from service when TCA was observed at a concentration of $7.5 \mu \mathrm{g} / \mathrm{L}$. Potable Wells 10 and 11 remained out of service due to the presence of TCA that exceeded the New York State DWS of $5 \mu \mathrm{g} / \mathrm{L}$. The Laboratory initiated the process to install carbon filtration at Well 11 in 1990 and expects that this well will be available for service during CY 1991. Process Supply Wells 101, 102, and 103 were used periodically during 1990 to provide cooling water to the AGS facility. Process Supply Wells 104 and 105 provided secondary cooling water to the MRR until March, 1990 when both we11s were placed out of service due to the presence of TCA in recharge water that exceeded the NYS DWS.

The Laboratory's potable water wells and cooling water supply wells are screened from a depth of about $15 \mathrm{~m}$ to about $46 \mathrm{~m}$, in the Upper Glacial aquifer, with one exception. We11 104 is screened at multiple depths: 40 to $43 \mathrm{~m}$ in the Upper Glacial and 60 to $90 \mathrm{~m}$ in the Magothy aquifer. As was shown in Figure 24, most of these wells are located west or to the northeast and are upgradient of the Laboratory's principle facilities in the local ground water flow pattern. As was indicated in Figure 25, about 16.7 MLD were pumped from these we11s in 1990. Grab samples were obtained from the potable wells on a quarterly basis and analyzed for radioactivity, water quality indices, metals, chlorocarbon compounds, trihalomethane compounds, and benzene, toluene, and xylene (BTX). Supply Wells 104 and 105 were sampled only once in 1990 for chlorocarbon and BTX compounds. Wel1 105 had a TCA concentration that exceeded the NYS DWS. A1though no organics were detected in the 1990 water sample from Well 104, this well had TCA concentrations in excess of the NYS DWS in 1989. Because discharge of organic compounds in excess of the NYS DWS is not authorized under the SPDES 
permit, and because there was uncertainty regarding the potential for upper to lower aquifer contamination, BNL placed both wells out of service in March, 1990.

Process Supply We11s 101, 102, and 103 were not sampled in 1990 by S\&EP. Water chemistry analyses were performed by the facility operators as needed to meet their operational requirements.

\subsubsection{Radiological Analyses}

The average radionuclide concentrations are reported in Appendix $D, T a b l e$ 40. The presence of cesium-137 in Potable We1ls 6 and 12 and beryllium-7 at Potable Well 12 does not appear to be related to Laboratory operations. Radionuclide concentrations in potable water are all small fractions of the applicable water standards or guides and do not pose a safety or health risk to individuals who drink or use the water on-site. The dose resulting from consuming $100 \%$ of the daily water intake from the highest concentration water sources would result in a committed effective dose equivalent of 0.01 mrem $(0.0001 \mathrm{mSv})$. Quality Control samples consisting of distilled and tap water from Building 535 are analyzed daily for gross alpha, gross beta, and tritium. These results are presented in Appendix D, Table 41 and can be used for comparison with other ground water sample results.

\subsubsection{Non-radiological Analyses}

The water quality and metals data for the Laboratory potable supply wells are shown in Appendix D, Tables 42 and 43 , respectively. With the exception of $\mathrm{pH}$, indices of water quality such as nitrates, sulfates, and chlorides were all well within the limits established in the NYS DWS. ${ }^{17,18}$ The pH values in these wells ranged from 5.8-7.9 and are typical of Long Island. ${ }^{35,36}$ The $\mathrm{pH}$ of water distributed by the BNL water treatment plant (WTP-EFF) ranged from 6.5 to 9.1 whil: the $\mathrm{pH}$ at Potable well 12, which introduces water directly into the distribution system; was 6.3 to 7.9 .

Samples from potable wells were analyzed monthly for residual chlorine and the presence of coliform bacteria. The analytical results were included in the monthly reports submitted to the SCDHS. The analyses indicated that bacteria were not detected in samples and the BNL potable supply is well within the requirements of the EPA National Prinary Drinking Water Standards ${ }^{19}$ and the New York State Sanitary Code. ${ }^{17}$

The majority of metals including silver, cadmium, chromium, mercury, and lead were not detected in the Laboratory supply system. Copper, manganese, and zinc were detected at levels below their respective NYS DWS. Iron was not detected in water samples collected at the well head of Potable Well 12 and was detected at $40 \%$ of NYS DWS in water from the BNL water treatment plant. Iron was detected at ambient levels in Potable Wells 4, 6, and 7 . The water from these latter wells is treated at the WTP which has an iron removal efficiency in excess of $90 \%$ and permits distribution of water (WTP-EFF) at concentrations below the $0.3 \mathrm{mg} / \mathrm{L}$ NYS DWS. Sodium was detected in all wells at ambient concentrations. 
Water samples are collected from the potable wells during the first month of each calendar quarter and are analyzed by a contractor laboratory which is certified by the NYSDOH for organic analyses in potable water. These samples are collected in order to monitor for compliance with NYSDOH requirements for a Community Water System and the National Interim Primary Drinking Water Regulations and are subinitted to the DHS. The results of these compliance samples are presented in Appendix D, Tables 44 and 45. These data indicate that the potable water from Wells 6,7 , and 12 at BNL met the NYS DWS or NYSDOH advisory limits. ${ }^{17,18}$ As indicated previously, TCA was detected in Potable well 4 in excess of the NYS DWS of $5 \mu \mathrm{g} / \mathrm{L}$. This compound was also detected at Wells 6 and 12 but at concentrations significantly lower than at Potable We11 4. Trace concentrations of chloroform were also detected at potable Wells 4 and 6 at concentrations corresponding to $3 \%$ of the NYS DWS.

During the second or third month of each quarter, BNL schedules the collection of potable water samples which are analyzed on-site by S\&EP for ten organic compounds. These samples serve both as a quality control on the contractor laboratory and as an additional source of organic data used in trend analysis of water quality. The results of this sampling program are presented in Appendix D, Tables 46 and 47. In 1990, the only organic compound detected in the BNL program for potable wells was chloroform at We11 6 and at the WTP effluent. Observed concentrations were $19 \%$ and $5 \%$ respectively of the NYS DWS.

In 1989, TCA concentrations of $13 \mu \mathrm{g} / \mathrm{L}$ were observed in water from supply we11 104 (FK). In 1990, as a result of the DOE Tiger Tean assessment, this well was placed in an out-of-service mode, until a decision is made regarding the need to close this well in an effort to ininimize the potential for channeliing of upper aquifer contamination to greater depths. In 1990, Supply We11 105 (FL) was found to contain TCA at a concentration of $31 \mu \mathrm{g} / \mathrm{L}$. Because discharge of water to a recharge basin containing contamination in excess of the NYS DWS was viewed by NYS as a violation of the SPDES permit conditions, this well was taken out of service as a source of cooling water for the MRR. No other chlorocarbon data, as reported in Appendix $D$, Table 46 were detected.

Water samples were also analyzed for BTX by BNL. These results are shown in Appendix D, Table 47. In all cases, these compounds were not detected in BNL potable or supply water.

\subsubsection{Ground Water Surveillance}

This network includes wells that are located both upgradient and downgradient of the following areas: on-site recharge basins, the STP sand filter beds, the Peconic River, the WCF, the CSF, the HWMF, the former landfill area, Building 650 sump, the Army Landfill ("X-26" site), and the Current Landfill. The location of all ground water surveillance wells is shown in Figure 30. Wells located in specific sections (grids) of interest are shown in Figures $31,32,33$, and 36. Appendix D, Table 48 provides a cross reference index which assigns grid coordinates for each well to the historic location identifier. For this report, both the old and the new well identifiers are used. The conversion to the grid numbering system was implemented in order to establish a uniform identification system for the monitoring wells. 


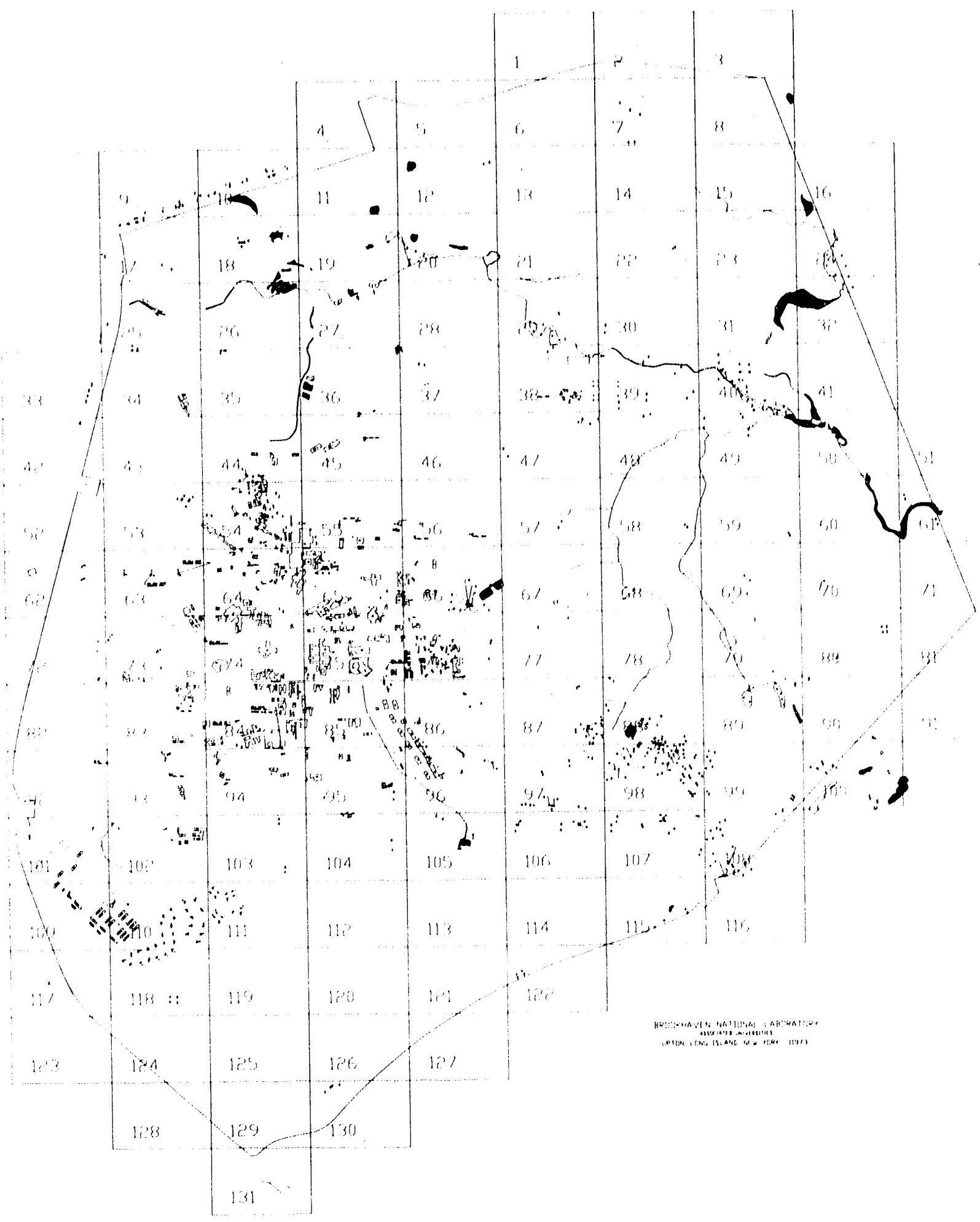

Figure 30: Location of Ground Water Monitoring Wells at Brookhaven National Laboratory 
The data presented in subsequent text and tables are compared to DCGs to determine compliance with operational limfts and, because the aquifer underlying " Nassau and Suffolk Counties has been designated as a "Sole Source", "37 the data are also compared to the EPA ${ }^{19}$ and NYS DWS, ${ }^{17,18}$

\subsubsection{Radiological Analyses}

The yearly average concentrations of radionuclides in samples from the wells adfacent to the sand filter beds at the S'TP, downstreain on the Peconfc River, and adfacent to the Meadow Marsh-upland recharge area are summarized In Appendix D, Table 50. The location of these wells is presented in Figures 30 and 31. Elevated gross beta and tritium concentrations have been found in on-site wells adjacent to the sand filter beds and the Peconic River. The observed levels are probably attributable to losses from the tile collection fleld underlying the sand filter beds and perlodic recharge to ground water from the Peconic River in this area. In 1990 , on-site gross beta ground water concentrations ranged from $2 \%$ to $7 \%$ of the NYS DWS. Tritium concentrations ranged from detection 1 imits to $11 \%$ of the NYS DWS. Strontium-90 concentrations ranged from nondetectable to $24 \%$ of the NYS DWS. Ten of the 15 wells monitoring these sites were abandoned in 1990 and of these, one well (40-04, prevlously XY) had strontium-90 concentrations exceeding DWS. Replacement of this monitoring well will be considered in the preparation of the BNL Ground Water Monitoring Plan. Gamna-emitting radionuclides were no' detected in any of the Peconic River or Meadow Marsh-upland recharge area monitoring wells.

In 1990, the cooperative program between BNL and the SCDHS continued for the collection and analysis of samples from wells serving private homes. As part of this program, samples were collected quarterly from 16 private drinking water wells in Suffolk County. Twelve of these sampling stations were from homes near the Laboratory, with the remainder from locations randomly selected by SCDHS. A total of 23 different locations were sampled in 1990. Samples were analyzed for gross alpha, gross beta, and tritium on a quarterly basis, while analyses for strontium-90 and gamma spectroscopy were performed annually. Results from this program, presented in Appendix D, Table 51, indicate that tritium was detected in samples collected from three locations adjacent to the Laboratory. (One location was a sampling point along the Peconic River and two locations were private potable wells.) The private wells in the sampling program are screened at depths ranging from 50 to 200 feet and had annual average tritium concentrations that ranged from below detection limits to $2255 \mathrm{pCl} / \mathrm{L}(83 \mathrm{~Bq} / \mathrm{L})$. Although above background, these data were consistent with data collected since 1979, and were less than $11 \%$ of concentration 1 imits and $3 \%$ of the dose 1 imit specified by the DWS ${ }^{19}$ for community water supplies. Gamma spectroscopy results from these private potable wells in 1990 indicated the trace presence of naturally occurring potassium-40. The observed concentrations were below the detection limit but above the two sigma counting error. They are reported as trace for trending purposes. The Peconic River sampling location was observed to contain cesium137. The reported concentration, $1.6 \mathrm{pCi} / \mathrm{L}(0.06 \mathrm{~Bq} / \mathrm{L})$, agrees we11 with the 1990 annual average cesium-137 concentration at the Peconic River site boundary Sampling Location $\mathrm{HQ}$ of $1.78 \mathrm{pCi} / \mathrm{L}(0.07 \mathrm{~Bq} / \mathrm{L})$ strontium-90 results are effectively at or below the analytical detection limits. 
The data for the samplas collected from control. wells, walls in the northeast and wast soctors, south boundary, contral part of the BNL site, the Curront and Former Landf11.s, Ash Deposfory, and tho IWW araa are shown in Appendix D, Tables 52 through 55. At the north boundary, Former Army Landf1.11, AGS, south boundary, and west side site we11s, (Appandix D, Table 52) most results were efther below the system detaction limfts or typloal of ground water not Impacted by laboratory operations. Tha highest gross bata lavel obsarved was along the south boundary at Location 130.02. The value corrasponds to a time when the sample water was inl1ky in color and there was a question regarding the dissolution of the bentonite seal. Baryl11um-7 was detected once at We11 Location 53-04 but not in subsequent samples. Downgradient of the AGS at Bu1lding 811 , sodium 22 was routinely detected at concentrations up to $1 \%$ of the DWS. Strontium-90 was a1so detected in these and other AGS area we11s in concentrations representing less than $14 \%$ of tha DWS. 


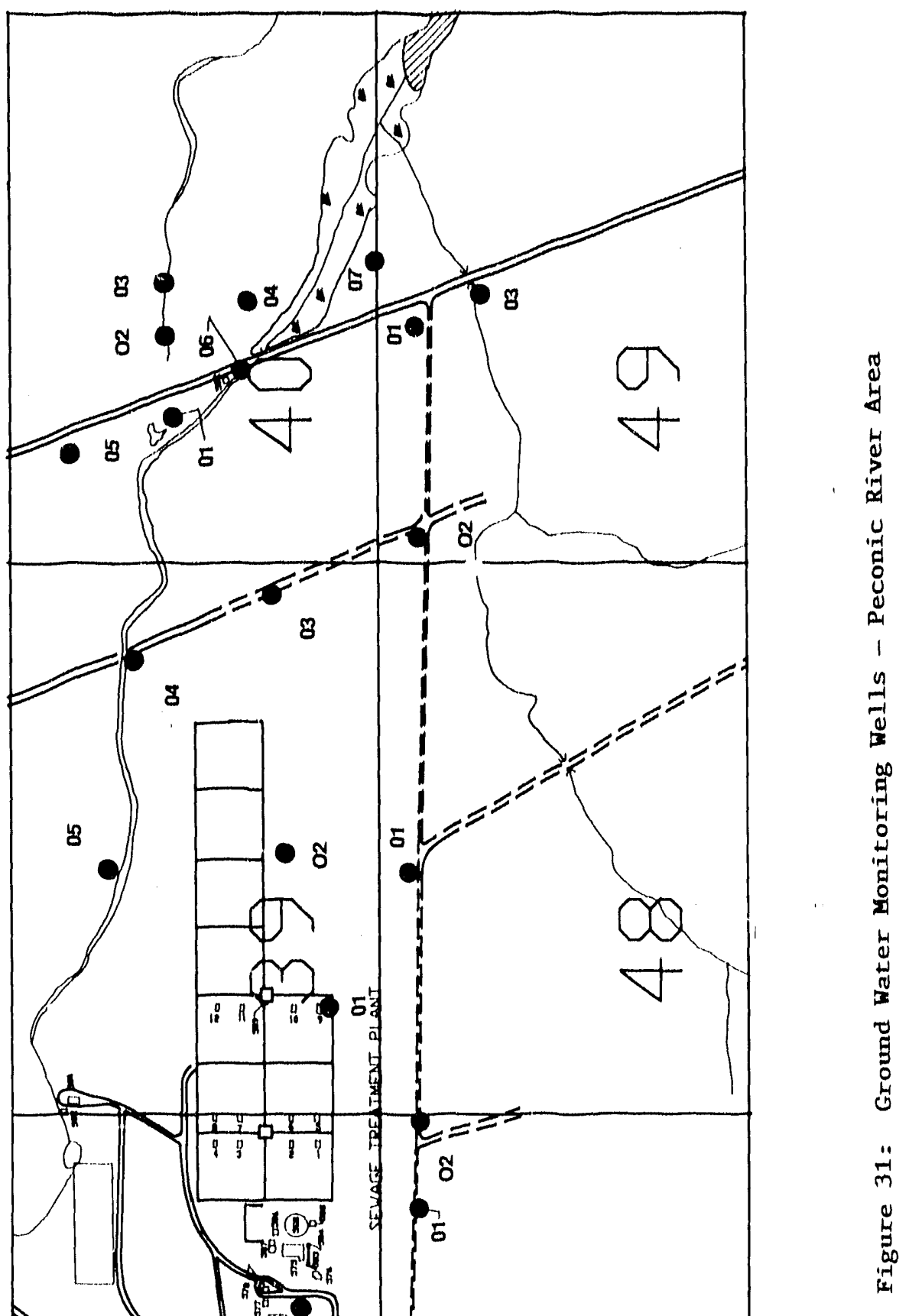




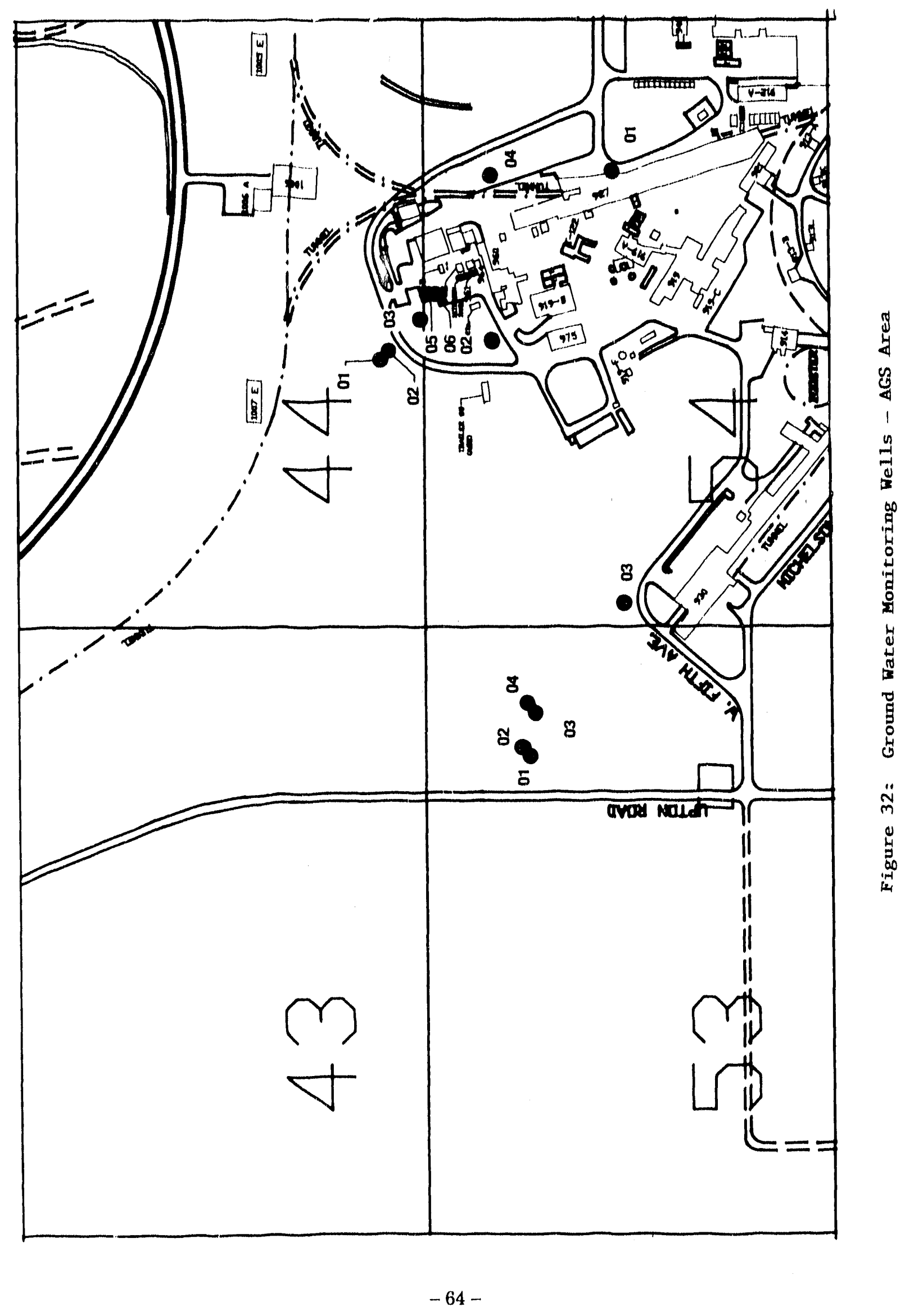


The location of wells installad to mond tor Bullding 830, the MPF, CSF, or Photography or Graphle Arts are shown $\ln$ Flgure 33 and the radionuelide concentrations observed fin 1990 samples are presented in Appendix D, Table 53. Excopt for a single elovated gross beta result at we11. $76-16$, gross bata concentrations were at amblent levels and all observations ware we 1.1 below the NYS DWS.

In the vicintty of Buflding 830 (Appendix D, 'lable 53), radiological rasults for ground water monftoring samples fndicated the prosence of cobalt-60 in each well semple. The cobalt-60 concentrations are most $1.1 \mathrm{kaly}$ rolated to operational activitias at Buflding 830 associated with the "d-waste" Iine leak al. though AGS storage of activated components outside on nearby soll may play a contributing role. The observed concentrations are less than $1 \%$ of the NYS DWS. We11 76-18 in the MPF area showed strontium-90 concentration lovels slightiy above amblent conditions but wel1 below (13\%) the NYS DWS. Ground water samples analyzed from monltoring walis near the Photography and Graphle Arts bullding Indfated no significant concentrations of radio-nuclides.

Radionuclide results for samples collected at the former ashfill and the current and the former landfill areas are presented in Appendix D, Table 54. No activity was observed in the ashf111. well sample. At the current landfili, ofght downgradient wells consistently show elevated gross beta concentrations; 14 we11s exhibit above ambient concentrations of tritium; seven wells (essentially those with elevated gross beta concentrations) have elevated strontium-90 levels; sodium-22 was detected in five we11s; and cesium-137 was detected in two wells. The highest annual average gross beta, tritium, strontlum-90, sodium-22, and cestum -137 concentrations were $35 \%, 95 \%, 53 \%, 0.2 \%$, and $0.4 \%$, respectively of the NYS DWS. In general, radionuclide concentrations in the downgradient current landfill wells are consistent with inorganic contaminants, specifically iron, observed at the same locations. The presonce of radionuclides in ground water. samples, collected from the current landflll area, is the result of BNL's past practice of placing low specific activity material in that location. This practice was terminated in 1978.

At the former landfili, the maximum tritium ard gross beta concentrations of: $1160 \mathrm{pCl} / \mathrm{L}(43 \mathrm{~Bq} / \mathrm{L}), 1.4 .93 \mathrm{pCl} / \mathrm{L}(0.55 \mathrm{~Bq} / \mathrm{L})$ were observed in Wel1.s $96-04$ and 97-03 respective1y. Strontfum-90 was detected at We11 97-03 at a concentration of $5.1 \mathrm{pCl} / \mathrm{L}(0.2 \mathrm{~Bq} / \mathrm{L})$. In all three instances, these radionuclide concentrations were we1l. below NYS DWS. The presence of radionuclides in ground water samples from the former landfill and chemical hole area is the result of BNL's past practice of placing low specific activity material in that location.

The ground water montoring program conducted at the HWMF (Figure 36) consists of a shallow well network located near the facility and a set of deeper we11s that extends out from the facility in the direction of ground water flow. The radiological results for the samples collected from this program are presented in Appendix $D$, Table 55. The elevated annual average gross beta concentrations were observed at three we11s locations: 88-04, 98-02, and 98-29. The observed concentrations were $81 \%, 42 \%$, and $26 \%$, respectively of the gross beta NYS DWS. Nineteen we11 locations exhibit tritiun concentrations in excess of ambient levels. The maximum annual average concentration observed in this 


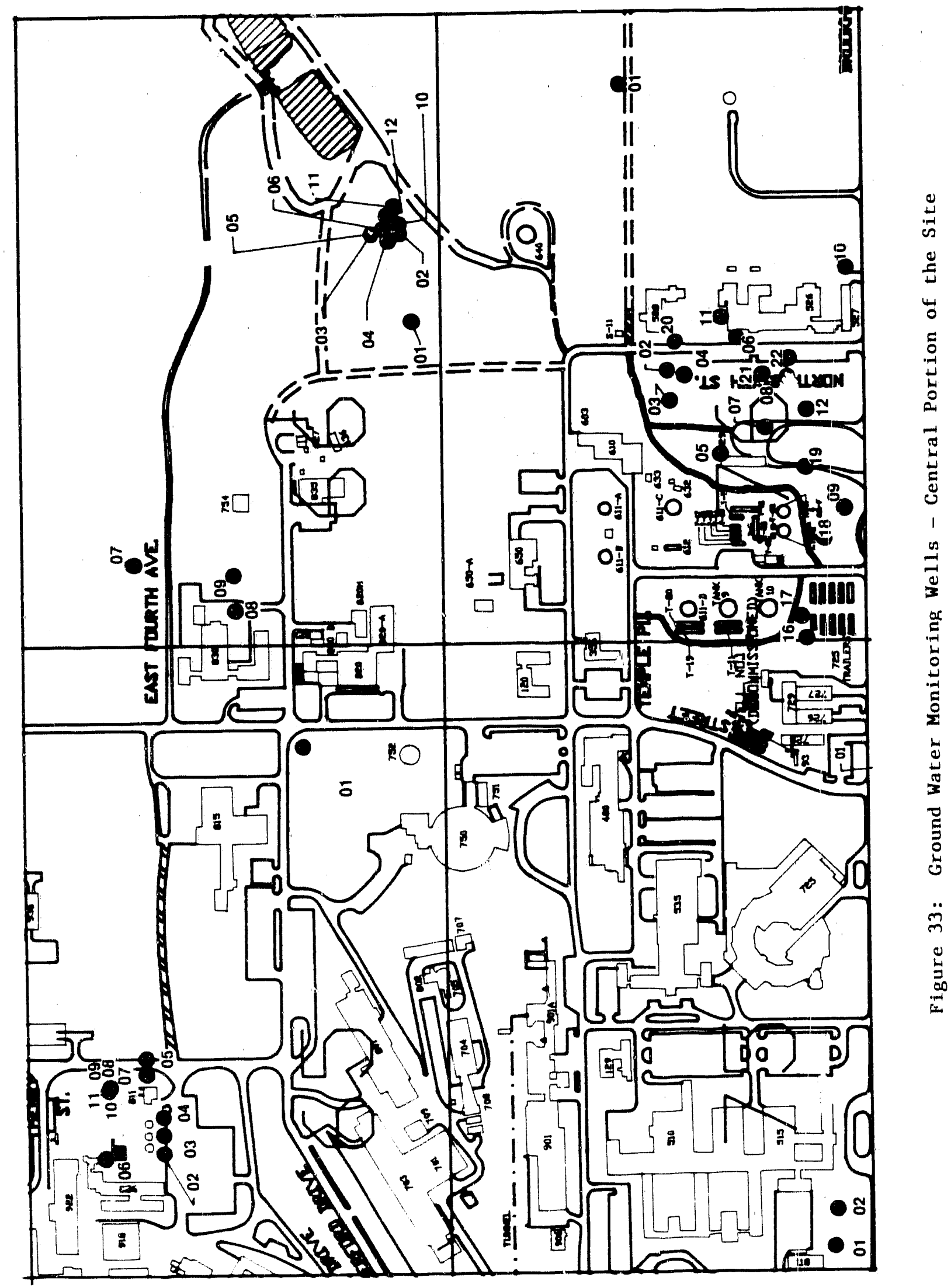




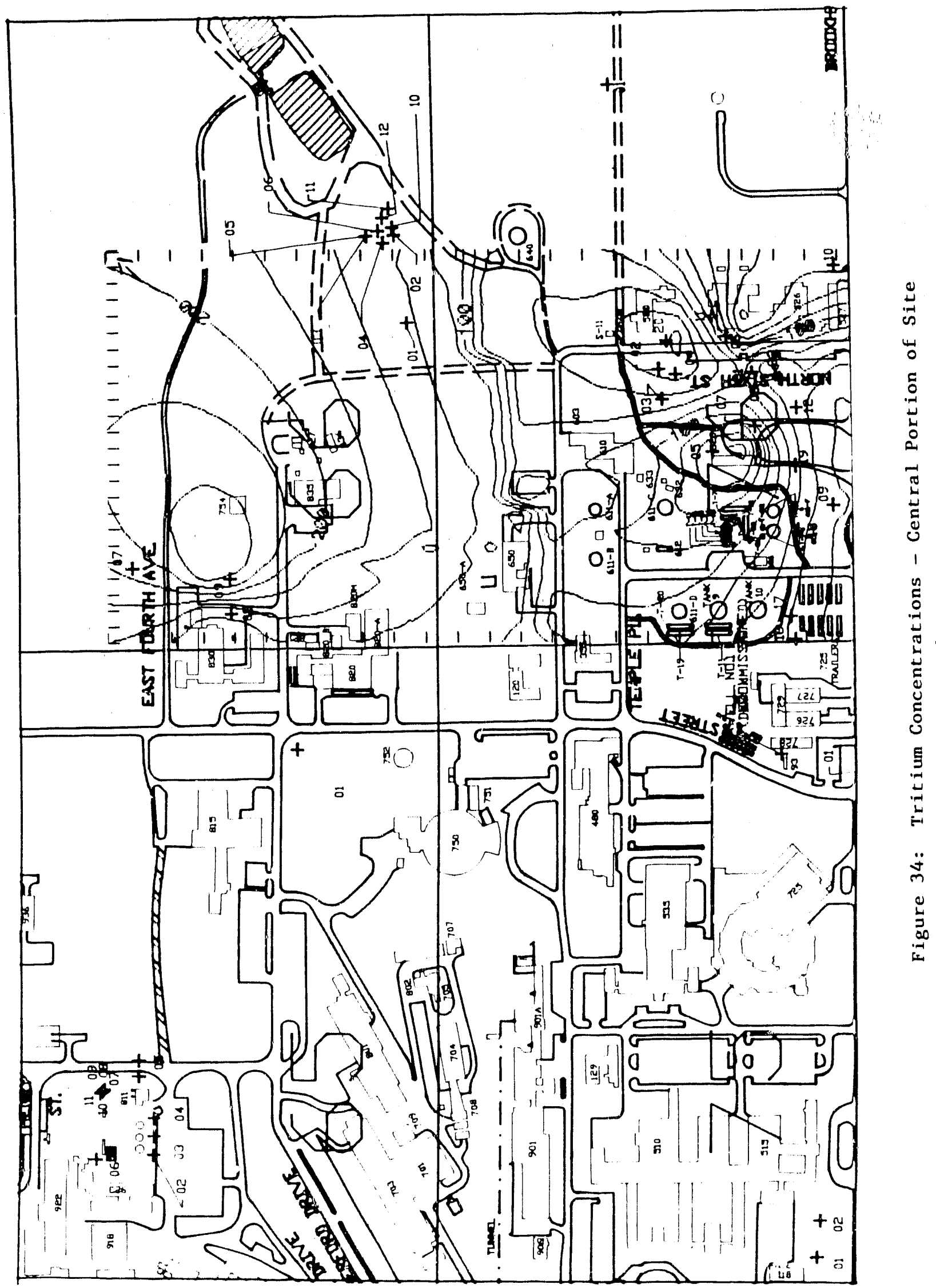




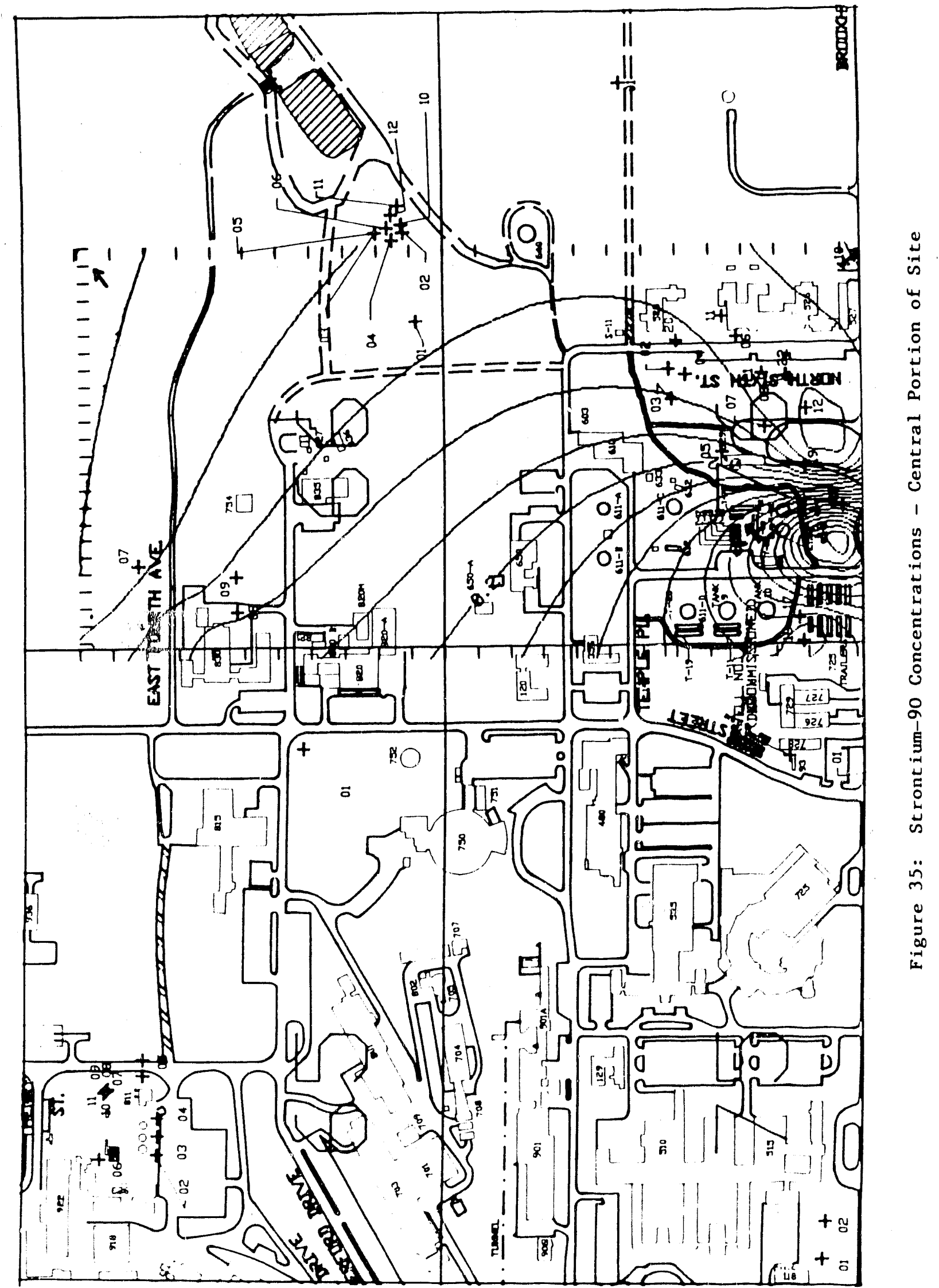




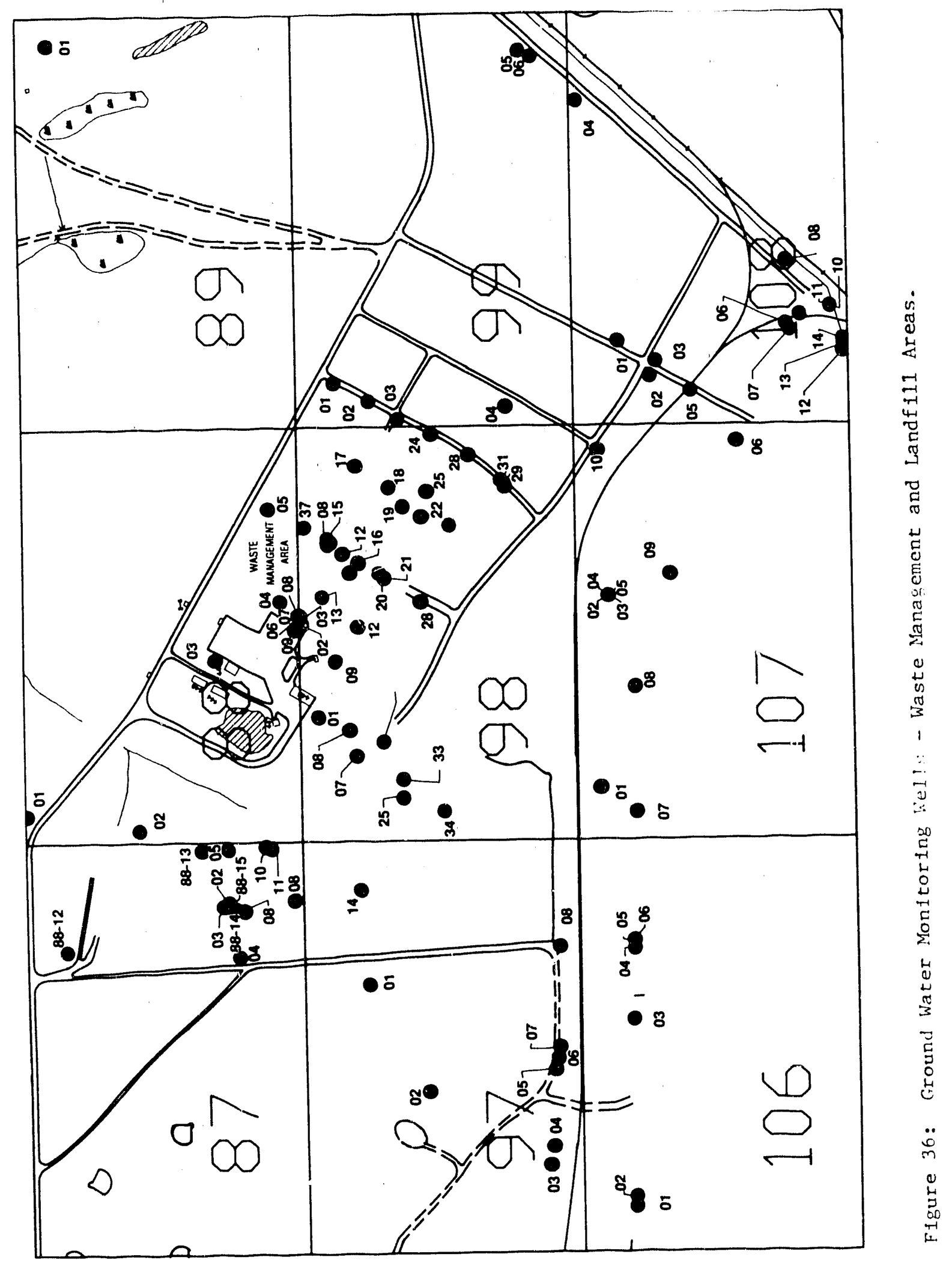


area was $27 \%$ of the DWS. Sodium-22 and cobalt-60 were detected periodically in samples from this area at concentrations substantially less than $1 \%$ of the DWS. Strontium-90 was detected in excess of the DWS it the three wells identified with elevated gross beta concentration. At Wel1 88-04, the strontium-90 concentration was $61 \mathrm{pCi} / \mathrm{L}(2.3 \mathrm{~Bq} / \mathrm{L})$; at Well 98-02 the strontium-90 concentration was 44 $\mathrm{pCi} / \mathrm{L}$; and at Well 98-29, the strontium-90 concentration was $32 \mathrm{pCi} / \mathrm{L}$ ( $1.2 \mathrm{~Bq} / \mathrm{L})$. The NYS and EPA strontium-90, DWS is $8 \mathrm{pCi} / \mathrm{L}(0.3 \mathrm{~Bq} / \mathrm{L})$. The locations where these concentrations were observed were well within the site boundary. Ground water concentrations at al1 site boundary stations were well within regulatory guidelines. Figures 37 and 38 depict the tritium and strontium-90 concentration contours for the HWM area.

In addition to the routine ground water monitoring program, gross alpha, gross beta, and tritium analyses were performed on a monthly basis during the first quarter of 1990 for samples collected from the spray aeration project wells. The approximate location of these we11s are indicated in Figure 36 . The P.mping Wells 98.05, 98-16, and 98-25 were totally inactive in 1990. Pumping Wells 108-02 and 108-09 ran only from January to March, 1990. The project was suspended at the request of NYSDEC and the DOE Tiger Team who expressed reservations regarding hydraulic containment of the plume. The radiological results from this sampling program are presented in Appendix D, Table 56. These data indicate the presence of low level tritium and periodic sodium-22 concentrations. These concentrations are $7 \%$ and $0.4 \%$ of the respective DWS. Al1 olier radionuclides were either not detected or at ambient levels.

\subsubsection{Non-radiological Analyses}

The data for wells adjacent to the sand filter beds and downstream of the Peconic River on- and off-site (Figures 30 and 31 ), are shown in Appendix D, Tables 56 - 59. In general, the data for samples obtained from these wells were comparable to those observed during previous years. ${ }^{10}$ The water quality data for this series of surveillance wells is reported in Appendix D, Table 56. Conductivity, chlorides, sulfates, and nitrate-nitrogen were not significantly different than values observed in BNL's control wells. The pH ranged from 4.7 to 7.1 which shows a slightly wider variation in $\mathrm{pH}$ than observed in control wel1s. Copper and zinc (Appendix D, Table 57) were detected in concentrations below NYS DWS. ${ }^{18}$ Silver, cadmium, chromium, mercury, and lead concentrations were al1 less than or equal to the method minimum detectable concentration. One manganese concentration in excess of NYS DWS was observed at Wel1 47-02, while iron was observed in five monitoring wells in excess of NYS DWS.

Some of these wells were also analyzed for chlorocarbon, trihalomethane, and BTX compounds. As can be seen from the data in AppendiX D, Tables 58 and 59 , all reported results for TCA, chloroform, and BTX were below the system detection limits.

The surveillance data for the current and former landfills, and ash repository wells are shown in Appendix D, Tables 60 through 63 . The BNL current landfill ceased operations in 1990 in accordance with the Long Island Landfill Law. Permanent closure of this facility will follow completion of a RI/FS for the area. Radioactivity and me rals data from wells monitoring the BNL current landfill are reported quarterly to NYSDEC. 


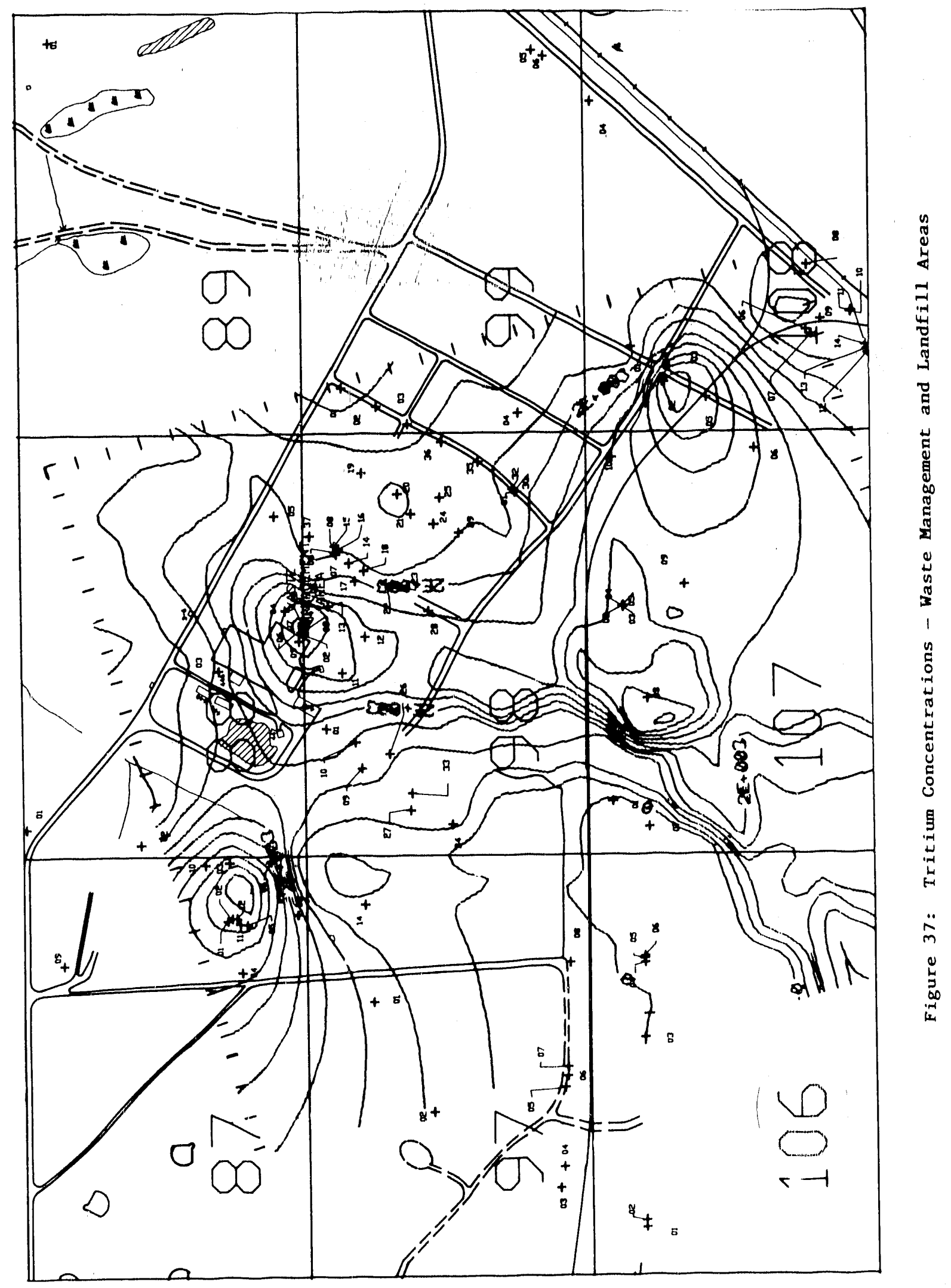




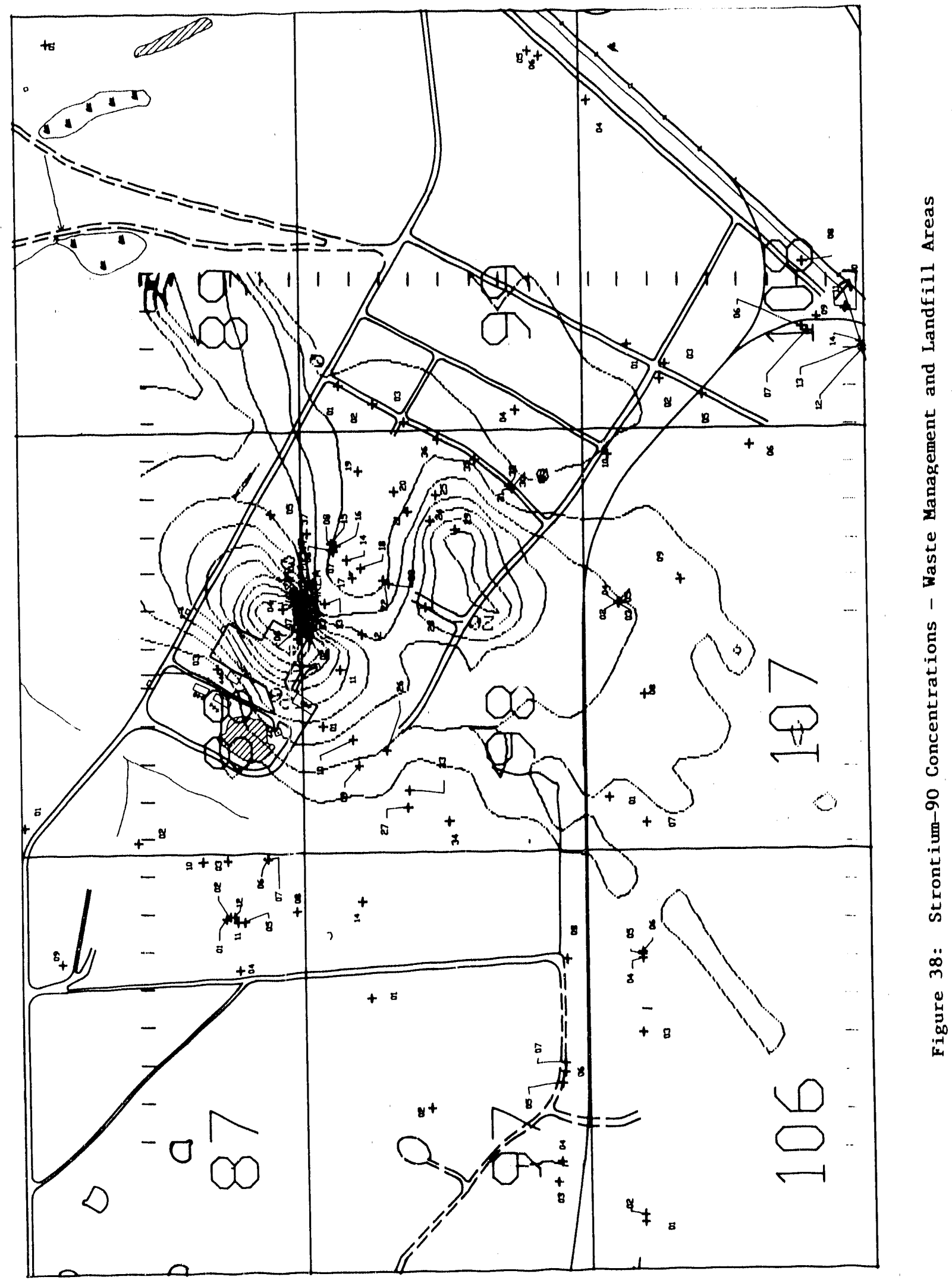


The pH data from the Current Landfill wells ranged from 5.1 to 7.9. In the downgradients wells (87-03,87-05,87-08,87-11,88-02, and 88-13), chlorides ranged from five to ten times ambient conditions as observed in We11 88-12. Sulfates in wells $88-02$ and 88-13 ranged from two to four times background levels in We11 88-12. Nitrate-nitrogen concentrations were consistent with on-site control well data. Metals data for the current landfill wills indicate that silver, cadmium, chromium, and copper were not detected in these samples. While the lead, mercury, and zinc were sporadically detected, these parameters were wel1 below the NYS DWS. Iron and manganese were detected at many wells in concentrations which exceeded the NYS DWS. The presence of most of these parameters in ground water samples collected from this area is consistent with past landfill activities.

At the Former Landfill area, the pH ranged from 4.9 to 7.02 and water quality parameters were cunsistent with data from control wells. Silver, chromium, copper, zinc, and lead were not detected in water samples from these wells. Cadinium, iron, and mercury were detected at levels below the NYS DWS. Manganese was the only inorganic parameter which exceeded the NYS DWS and this occurred only in We11 97-05.

The ground water survefllance wells at the landf1l1 areas and control wells were analyzed for chlorocarbon, trihalomethane, and BTX compounds. At the Current Landfill, benzene was detected at downgradient well locations. Only one of these concentrations (Location 87-03) exceeded NYS DWS. Toluene was detected in one well (Location 88-13) which exceeded the NYS DWS. The presence of xylene was indicated in one well, but it did not exceed the NYS DWS. Of the other organic compounds which BNL analyzes, TCA and DCA were detected in three and five wells respectively. The DCA was detected in five wells used to monitor the Current Landfill. The maximum values observed in two of these wells exceeded the NYS DWS by a factor of two. At the Former Landf111, of the eight wells sampled for chlorocarbon, trihalomethane, and BTX compounds, none had concentrations exceeding MDLs. In 1990, however, six wells were removed from the Former Landfill monitoring schedule due to their poor condition. Several of these wells which were sampled in 1989 and which indicated chlorocarbon, trihalomethane, and/or BTX impacts to the underlying aquifer system, will be replaced with new monitoring wells as the remedial investigation for this area of concern proceeds in $C Y 1991$ and CY 1992.

At the HWMF, the routine ground water monltoring program consists of a shallow well network located near the facility and a set of deeper wells that extend out from the facility in the direction of ground water flow. The average water quality and metals data for the HWMF are presented in Appendix D, Tables 64 and 65. Water quality parameters were all within ambient conditions. Metals such as silver, lead, copper, and cadmium were not detected in any of the wells. Trace concentrations of chromium, mercury, and zinc were detected sporadically. Iron and manganese were detected at ambient (trace) levels and were consistently well below NYS DWS. Iron concentrations in ground water at the HWMA are substantially lower (by as much as three orders of magnitude) than the adjacent Current Landfill area located imnediately to the west. 
The results for organic analyses performed on samples collected from these wells are presented in Appendix D, Tables $66-67$. The presence of TCA was not detected in thirteen wells but was observed in five survelilance wells at concentrations that exceeded the NYS DWS; these wells included 88.04, 98-02, 108 . 05, 108-12, and 108-13. Tetrachloroethylene and DCA were detected in Monftoring Wells 88-04 and 98-02, respectively; in each case exceeding the NYS DWS. Chloroform was detected at trace levels in only one well: $108-05$ at a concentration that was, substantially below the NYS DWS. No BTX compounds were detected in 1990 in the HWMF monitoring wells.

The five pumping wells used in the HWMF spray aeration project were not sampled and analyzed in 1990, following temporary shut down of that operation.

Samples were not collected from spray aeration profect pumping wells for VOC analyses during 1990. During the first quarter of 1990, Pumping We11s 108..02 and 108-09 were operating in the winter, but not in a spraying mode, Sampling for organic compounds was not scheduled for winter mode operation, as stated earlier, the project was suspended upon the arrival of the DOE Tiger Team and was not restarted in 1990. Concentrations of VOCs in the surveillance wells used to define the TCA plume recommended and installed by H2M/Roux in the 1r 1.985 HWMF study ${ }^{38}$ appear to have declined substantially as a result of the spray aeration project. For the most part, the original four VOC compounds identified in the plume in 1985 (TCA, TCE, PCE, and chloroform) were at non-detectable levels with the exception of Monitoring Wells 88-04, 98-02, 108-05, 108-12, and 108-13.

The MPF is the holding area for most fuels used at the CSF. The potential for ground water contamination in this area is monitored by one upgradient well and 13 downgradient wells. The results for water quality, metals, and organic analyses performed on samples collected from these surveillance wells are presented in Appendix $D$, Tables 68 through 71 . The water quality parameters are consistent with ambient levels. Silver, cadmium, copper, and lead were not detected in water sampled from this area. Trace quantities of mercury and $z$ inc were identified at concentrations that were substantially below the NYS DWS. Only iron and manganese were found in concentrations which exceeded the NYS DWS.

Analyses of samples from this location for petroleum products identified the presence of BTX compounds at concentrations in excess of the NYS DWS in several of the monitoring wells that straddle the surface of the water table (Appendix D, Table 71). Benzene, ethylbenzene, toluene, and xylene or combinations of these compounds were observed in five of the CSF wells at concentrations exceeding NYS DWS ranging from a factor of two to a factor of nearly 50 . No BTX compounds were detected in the five MFP monitoring wells, nor was free product (oil floating on top of the ground water) observed at any of these locations. Chlorocarbon compounds were detected in four wells from the MFP and CSF areas. At wel1 76-21, the TCA concentration exceeded the DWS by a factor of four; the TCE concentration exceeded the DWS by a factor of seven; the PEC concentration exceeded the DWS by a factor of 26 . Other wells where chlorocarbon data exceeded the DWS were $76-19,76-08$, and $76-05$. 
Monftoring wells at Buflding 830 and the Photography and Graphic Arts Bullding (PG\&A) were sampled in 1.990 and the analytical data for water quallty parameters, metals, chlorocarbons, and BTX compounds are reported in Appendix D, Tables 72 - 75. No apparent ground water impacts are evident for any of the parameters analyzed in the vicinity of these specific lab faclitites.

Water quality data for the north boundary, Army Landf11, AGS, Building 811, west sector, and south boundary monitoring wells are presented in Appendix D, Tables 76 - 79. Water quality parameters and metals in these areas were either below detection limits or sporadically detected at trace levels. Iron exceeded DWS in wells at the north boundary, AGS, and south boundary but cannot be directly attributed to any lab activities. The BTX compounds were detected only in We11s 18-01 and 53-01 in the form of toluene at concentrations below DWS. The former well has been spray painted once and continually vandalized; the spent paint can indicate toluene as an ingredient. Chlorocarbons in the form of TCA have been detected above DWS in one west sector well and one south boundary well. These are Wel1s 83-02 and 130-02, respectively. The latter well has been the subject of Graghty and Miller's off-site contamination report discussed in Section 7.7 of this report.

\subsection{Laboratory Qual1ty Assurance}

The EM program, which includes survelilance monttorting as well as compliance monitoring, utilizes on-site radiological and analytical chemistry laboratories as well as off-site contractor laboratorles. The S\&EP Analytical. Chemistry Laboratory is certified by NYSDOH for metals and anions under potable water analyses.

During CY 1990, certification for purgeable organic compounds analyses was changed and inccrporated into the nonpotable chemistry category; this $1 . s$ due to the fact that, under NYSDOH laboratory certification rules, a sub-category under potable chemistry cannot be split for the purpose of certification. Since only some of the analytes of the sub-category are needed for certffication, on the advice of the NYSDOH, the category is changed from potable to non potable chemistry under which analytes of interest can be chosen from a sub-category. However, the essential elements of quality control and detection $11 \mathrm{mits}$ achieved for the sample analyses are in line with the potable chemistry.

The S\&EP Radiological Laboratory participates in the DOE Environmental Measurements Laboratory QA Program and the EPA Nuclear Radiation Assessment Division (EMSL-LV) Intercomparison Study. The results of these intercomparison studies are summarized in Appendix $\mathrm{E}$.

Most of the data that are generated to comply with environmental regulations are analyzed by off-site contractor laboratories. This information is used for the SPDES discharge monthly monitoring reports, WT'P monthly reports, and the CSF semiannual. reports, Procedures are established for collection of all. samples and analyses of those samples performed on site. Audits of contractor laboratories are performed on a perlodic basis and are coordinated by the $Q A$ officer. During CY 1990, three off-sfte laboratories were reviewed for QA/QC compliance and competence of required methods. 


\subsection{OFF-SITE DOSE ESTIMATES}

\subsection{Dose Equivalents due to Alrborne Effluents}

The mafor radionuclides released from BNL afrborno effiluent discharge polnts were trittum, oxygen-1.5, and argon-41. The measured tritium concentrations and dose equivalents at the ste boundary are shown in Appendix $D$, Table 80. The highest annual average site boundary concentration of tritium vapor was $7.9 \mathrm{pCl} / \mathrm{m}^{3}(0.29 \mathrm{~Bq} / \mathrm{L})$ at Monftoring Location 16 (NNW Sector) and the coinmiteted effective dose equivalent (inhalation and skin absorption) was 0.006 mrem $(0.00006 \mathrm{mSv})$ for the hypothetical indlvidual residing at that location. By comparison, the site boundary tritium dose calculated ustng source term data and CAP88 are presented in Appendix $D$, Table 81. The exposure rates due to argon-41 and oxygen-15 were not measured at the site boundary. The dose-equivalent rates for these radionuclides, calculated using CAP88, are presented in Appendix $D$, Table 82. The maximum site-boundary dose-equivalent from argon-41 and oxygen-15 was calculated to be $0.066 \mathrm{mrem} / \mathrm{a}(0,00066 \mathrm{mSv} / \mathrm{a})$. The maximin st.te boundary dose from all three radionuclides was $0.067 \mathrm{mrem} / \mathrm{a}(0.00067 \mathrm{~ms} v / \mathrm{a})$.

The collective (population) dose equivalent was estimated for radionuclides released to the afrborne environment using measured effluent release data and recorded BNL meteorological parameters. Using actual source terms and meteorological data at the given release point should yield the best projection of airborne concentrations, and thus dose to the general population. This approach also minimizes the effects of local micrometeorological conditions which may exist, resulting in dffferences between the measured and expected tritium concentrations at the perimeter monitoring stations.

Collective total body doses resulting from the radionuclides released from each facility are presented in Appendix D, Table 83. Argon-41 contributed a collective dose equivalent of 1.30 person-rem $(0.0130$ person-Sv $)$ which is essentially the entire collective dose equivalent for the site. The dose equivalent contributions from tritfum and gallium-68 were 0.012 and 0.0081 person-rem $(0.00012$ and 0.000081 person-Sv), respectively, This is deplcted graphically in Figure 39. The fraction of collective dose as a function of facility is presented graphically in Flgure 40. The 1990 population collective dose-equ" "'ent resulting from the release of atrborne radlonuclides by the Laboratory was 1.33 person-rem $(0.0133$ person-Sv). This can be compared to the 1990 population collective dose-equivalent due to cosinfe and terrestrial natural background of 291,000 person-rem (2,910 person-Sv). The Laboratory airborne releases comprised $0.0005 \%$ of the total dose due to natural background.

\subsection{Dose Equivalents due to Liquid Effluents}

Since the Peconic River is not used as a drinklng water supply, ${ }^{39}$ nor for 1rrigation, its waters do not constitute a direct pathway for the ingestion of radioactivity. However, the Peconic River does recharge the aquifer and acts as a linfted source for sport flshing. In 1990, the collective dose equivalent resulting from the discharge of radioactive materlals to the Peconde River has been computed by evaluating private potable water. 


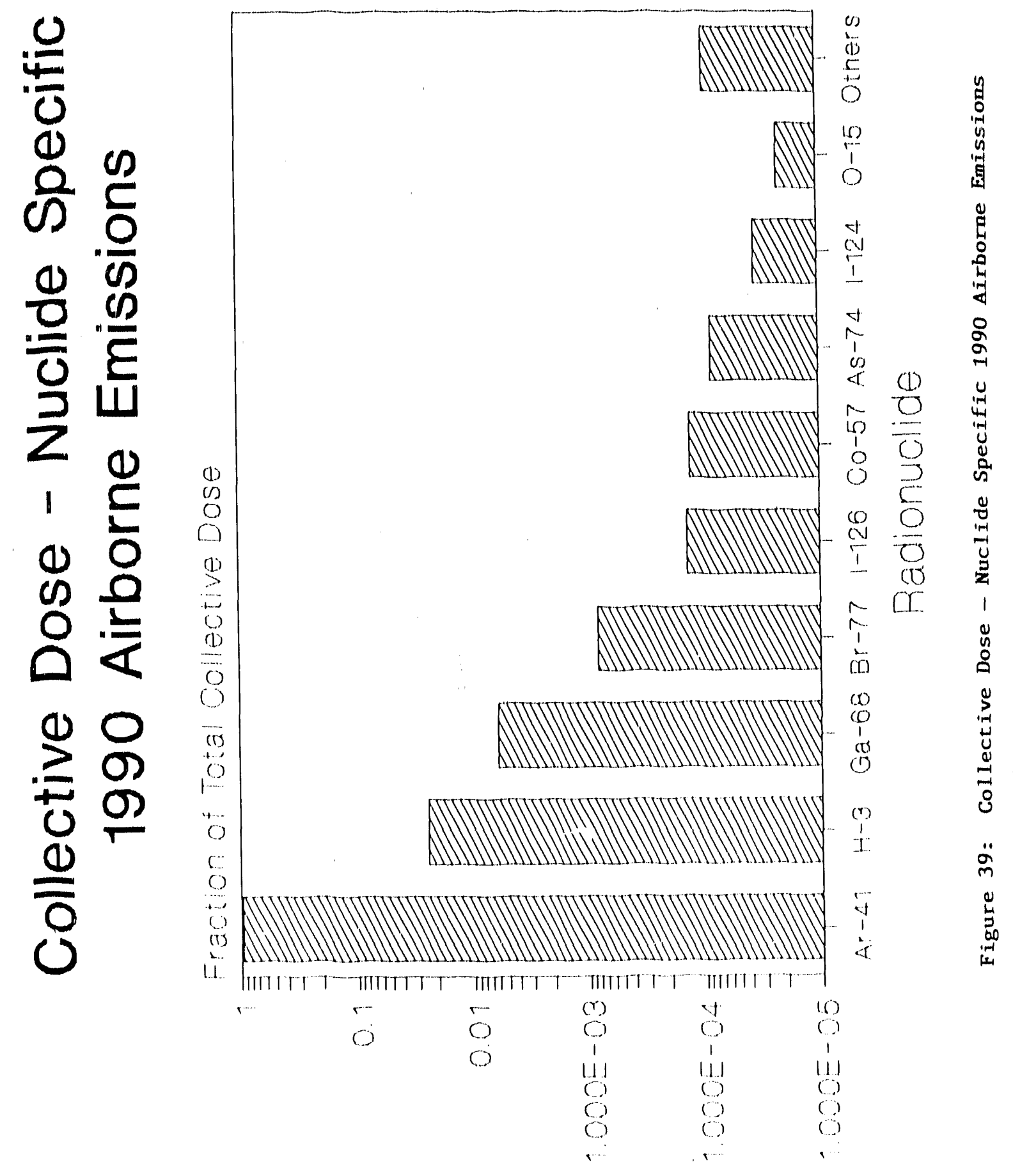




\section{Fraction of Collective Dose by Facility}

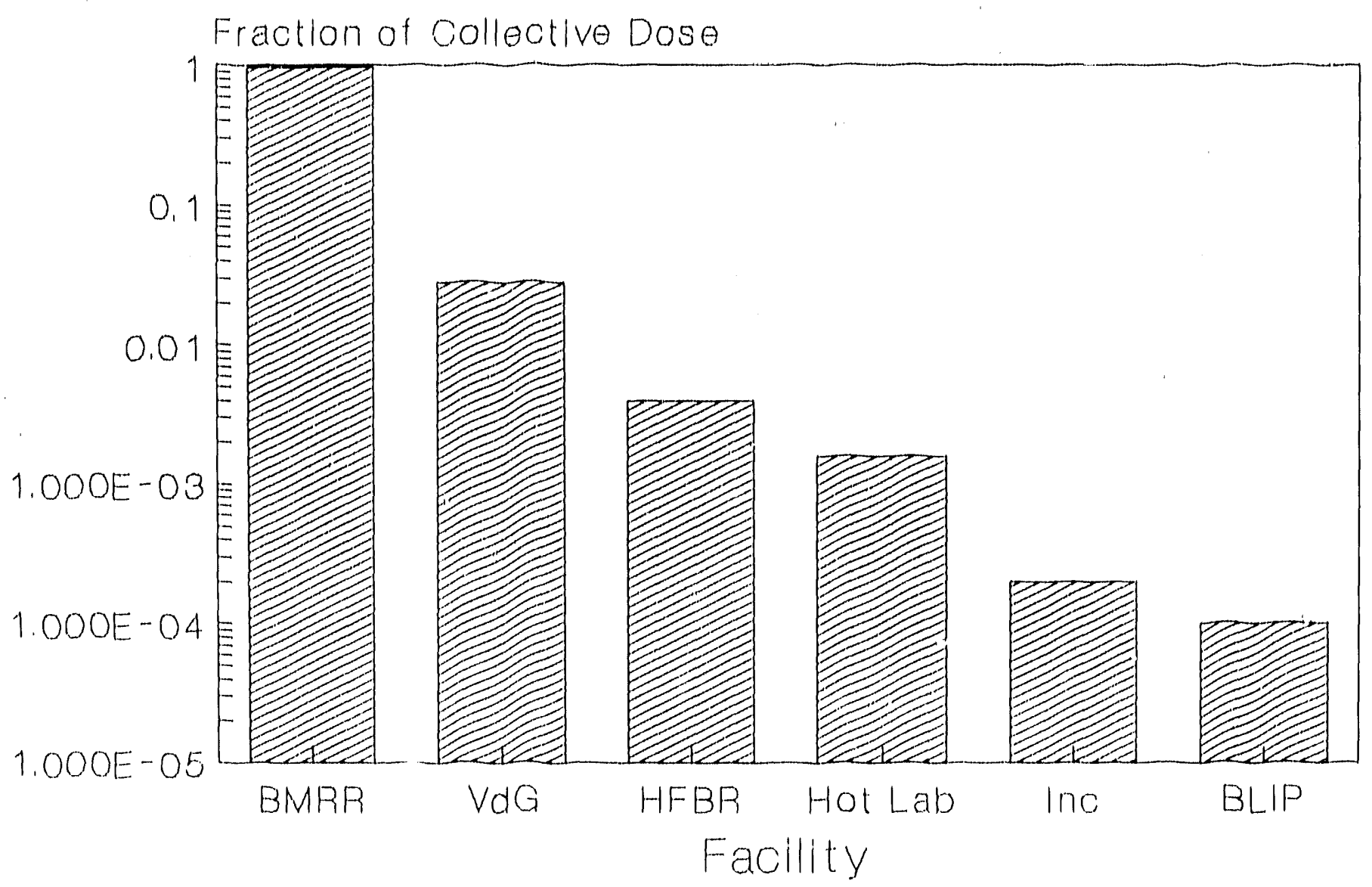

Figure 40: V'raction of Collective Dose by Factlity 
For the drinking water pathway, only tritiun was datectad in off asteo potabla wa11.s. The highost anmul average concentration for a aingla rasidenca was $2,255 \mathrm{pCl} / \mathrm{L}\left(83 \mathrm{~Bq} / \mathrm{L}_{1}\right)$. The avarage conoentration for the group of postetve tritfum concentrations at private potable we1.1s was $2,020 \mathrm{pCl} / \mathrm{L}(75 \mathrm{~Bq} / \mathrm{L})$. This corresponds to a commltted offective close equivalent to tho maximum individual of $0.1 .0 \mathrm{mrem}(0.001 \mathrm{mSv})$ and a colleotive dose aquivalent to the population at rlak (assumed to be not more than 500 parsons) of 0.052 person-rem $(0,00052$ person-Sv). The data are summartzed In Appendix D, Table 84.

The cestum- 137 concentiations in fish samples colleoted from Paconto River and control locations are reported fn Appendlx. D, Table 39. Using the method descrtbed in Appendix $B$, the maximum individual comntted collective doso equivalent was calculated to be 0.75 mrean $(0.0075 \mathrm{mSv}$ ). The population colleotive dose equivalent was calculated to be 0.427 person-rem $(0.00427$ person. Sv). The water and fish pathway dosimetric results are sumarized in Appendix D, T'abile 84.

\subsection{Collective (Population) Dosa Equivalent}

The collective (population) dose equivalent (total population dose) beyond the st.te boundary, within a radius of $80 \mathrm{~km}$, attributed to Laboratory operations during 1990 was 1.8 person-rem $(0.018$ person-Sv) and was obtained by the summation of the doses from the pathways discussed prevtously in this report. The data are sumnarized in Appendix D, Table 85.

The collective dose equivalent to the population withln an $80 . \mathrm{km}$ radius of the Laboratory, due to extarnal. radiation from natural background, amounts to about 291,000 person-rem/a $(2,91.0$ person-Sv), to whtch about 97,000 person-rem/a (970 person-Sv) should be addad for Internal radioactivity from natural sourcas. 


\subsection{REGULATORY AFFAIRS}

\subsection{Brookhaven National Laboratory - Suffolk County Agreement}

In September, 1987, BNL formalized an agreement with the County of Suffolk $k^{39}$ wherein these two organizations in the spirit of comity move to achieve the highest practical level of environmental protection to the citizens and lands of Suffolk County. While it is recognized that the Laboratory makes every effort to operate in compliance with all applicable Federal and State regulations, in accordance with this agreement, BNL has made a commitment to conform with the applicable environmental requirements of the Suffolk County Sanitary Codes related to public health and environmental protection. As a result of this agreement, several areas of activity have taken place since its formalization. These activities are discussed in more detail in Sections 5.1.1, 5.1.2, and 5.1.3 of this report. As a follow-up to routine activities, and to ensure that information regarding issues of concern to both organizations reaches appropriate levels of management, senior management from SCDHS and BNL meet on a quarterly basis.

\subsubsection{Review of Engineering Design Drawings}

Brookhaven National Laboratory agreed to submit plans for construction projects that are regulated by Articles $6,7,10$, and $12^{40-43}$ to the SCDHS for review for compliance with the environmental requirements of these codes. During 1990, a variety of engineering design drawings for the construction or modification of storage tanks, upgrading of drum storage areas, and connections to BNL STP were submitted to the SCDHS.

All comments provided by the SCDHS were reviewed and, where applicable, were incorporated into the final design plans. As part of the BNL engineering design review process, the collaboration with SCDHS on these reviews will continue in CY 1991.

\subsubsection{Registration of Toxic Liquid Storage Facilities}

The intent and purpose of Suffolk County Sanitary Code Article $12^{43}$ is to safeguard the water resources of the County from toxic and hazardous materials pollution. One of the requirements of this article is that any facility in Suffolk County which is used to store toxic or hazardous materials, as defined by che SCDHS, must be registered with the SCDHS.

In accordance with Section 760-1207 of Article 12, BNL submitted Toxic and Hazardous I.iquid Storage Registration Forms to the SCDHS in July, 1989. Approximately 200 storage facilities were registered in this submittal. An update to this regiztration package was submitted to the SCDHS in March, 1990. Additional updates wili be submitted to the SCDHS as existing facilities are upgraded or new facilities are proposed. 


\subsection{SPDES Permit Renewal}

Brookhaven National Laboratory has a SPDES Permit from the NYSDEC which authorizes the discharge of the effluent from the STP to the Peconic River as well as the discharge of non-contact cooling water from various facility operations into five recharge basins on-site. This is issued by the NYSDEC and has a Permit No. NY-000-5835. The expiration date for the BNL SPDES permit was May 1, 1988.

In accordance with the appropriate New York State SPDES permit regulations and procedures, BNL submitted an application package for the renewal of its SPDES permit to the NYSDEC on October 30, 1987. Under the NYS Uniform Procedures Act, ${ }^{44}$ when i permittee has made a timely and sufficient application for a permit, the existing permit does not expire until the application has been finally determined by the issuing agency. Therefore, the Laboratory has authorization to continue operating under the previous permit conditions.

Efforts to renew the SPDES permit continued during the CY 1990. These efforts included (1) the submittal of information describing best management practices for waste management at BNL and the mechanisms utilized to educate employees at BNL regarding the proper methods of handling and disposal of industrial wastes; and (2) the submittal of results for organic analyses from grab samples collected at recharge basins. In addition, a meeting was held to resolve some of the questions raised by the Tiger Team regarding the inslusion of specific sources into the permit. Additional data requests were made by NYSDEC which required modification to existing processes in order to facilitate collection of samples. These requests will be addressed in 1991.

\subsection{Compliance with State Pollution Discharge Elimination System Discharge Limitations}

Liquid effluent discharges to five recharge basins and the STP discharge to the Peconic River are subject to the conditions of the SPDES Permit No. NY000-5835, authorized by the NYSDEC. Monthly reports are submitted to both the NYSDEC and the SCDHS which provide detailed analytical results and performance information regarding the operational activities at the STP. These data indicate a general compliance rate of greater than $99 \%$ for all parameters monitored. Monitoring data are presented in detail for this discharge point in Appendix $D$, Tables 13 - 16. Specific instances of noncompliance during 1990 include five occurrences of suspended solids in excess of the SPDES permit limit and one instance where total coliform was measured above the SPDES discharge limit. The increase in suspended solids is believed to be due to the liming process which was initiated to correct the drop in $\mathrm{pH}$ as the water passes through the sand filter beds.

The SCDHS collects samples several times per year from the STP and conducts inspections of this facility on a quarterly basis for the NYS SPDES program. The analytical results of those samples collected during 1990 have been within limits. The DHS inspections have typically rated the STP as satisfactory. 
As part of the SPDES renewal process, BNL collected samples from recharge basins for organic analyses. The results, which were submitted to NYSDEC in February, 1990 observed the presence of TCA in Recharge Basin HP (Outfall 004). As part of their compliance verification process, NYSDEC collected samples from all outfalls at BNL on March 13, 1990. Analytical results for their samples indicated the presence of TCA at outfall 004 at $20 \mu \mathrm{g} / \mathrm{L}$ and iron at the WTP recharge basin (Outfall 007 ) at $4 \mathrm{mg} / \mathrm{L}$ which resulted in the issuance of a NOV issued by NYSDEC on May 17, 1990. The source of TCA at Outfal1 004 was identified as ground water obtained from supply wells for the MRR; their use was discontinued immediately. The elevated iron concentration at Outfall 007 is the result of backwash discharged from the WTP. Monitoring requirements for iron will be incorporated into the renewed SPDES permit for Outfall 007 . Brookhaven National Laboratory is developing a program to evaluate the impact of this discharge on the ambient ground water in the vicinity of the WTP in accordance with a request from NYSDEC. In addition, TCA was detected at a concentration of 39 in a sample collected by NYSDEC at Outfall 001. As a result, BNL commenced collection of a monthly grab sample for TCA analyses at Outfall 001; the results are included on the monthly discharge monitoring report.

At the recharge basins, flow and $\mathrm{pH}$ are the parameters that must be monitored under the conditions of the BNL SPDES permit. In addition, as part of the routine environmental monitoring program, water discharged to these basins monitored for water quality, metals, and radioactivi.ty. The analytical results for samples collected from these basins are presented in Appendix D, Tables 7 19. These data indicate that except for $\mathrm{pH}$ and iron, the discharge to these basins met both the SPDES permit conditions and NYS DWS for metals and other water quality parameters. In addition, collection of grab samples from the recharge basins for VOC analyses was initiated in 1990. Analytical results are presented in Appendix D, Tables 19A and 19B. No VOCs were detected in the grab samples with the exception of chloroform, which was found in concentrations ranging from 2 to $5 \mu \mathrm{g} / \mathrm{L}$. The NYS DWS for chloroform is $100 \mu \mathrm{g} / \mathrm{L}$.

A number of buildings at BNL are still served by cesspools that discharge to ground water. Although most of these pools receive only sanitary discharges, the pools at twelve facilities, have the potential to receive industrial discharges from sinks and work areas. The industrial discharges to these cesspools are not in accordance with NYSDEC SPDES regulations and Articles 7 and 12 of the Suffolk County Sanitary Code. ${ }^{42,44}$ Brookhaven National Laboratory had a line item project which provided connections to the site sanitary system for these facilities. This project was completed in 1990 and is discussed in more detail in Section 7.1.2 of this report.

\subsubsection{Upstream Monitoring of STP Influent and Automated Diversion Capability}

As part of corrective actions resulting from a June, 1988 unplanned release of radioactive materials into the sanitary system, ${ }^{45}$ a monitoring system was installed upstream of the STP that would provide advanced warning of liquid effluent streams that may have the potential to exceed SPDES permit conditions at the STP. The site selected was Manhole 1.92 which is located about 50 meters down stream from the last point of entry into the sewer line system and about 1.8 $\mathrm{km}$ upstream from the STP. In 1989, a V-notched weir, pH and conductivity probes 
were installed and tested. In 1990, radioactive measurement capability was added to the system. Also, telemetry of data was completed to both the STP and the Chilled Water Facility. The system hecame fully operational in the first quarter of 1990 with on-line monitoring of $\mathrm{pH}$, conductivity, and gamma activity. If the monitoring instrumentation detects liquid discharges that are outside the range of conditions that are acceptable for release under the SPDES permit, an alarm is actuated both locally and at a constantly manned console at the Chilled Water. Facility. This early warning provides about one hour of response time prior to the material reaching the STP. The second action that was completed in 1990 relating to the June, 1988 incident was the installation of automated diversion capability at the STP. Prior to this time, diversion of STP effluent to one of the two lined holding ponds required about 20 minutes of manual labor to initiate the diversion. The installation of automated equipment eliminates the time requirement to initiate diversion once the need is recognized.

\subsection{Closure of Landfil1}

Brookhaven National Laboratory operated the current landfill under a permit issued by the NYSDEC. This permit was up for renewal on April 30, 1988. In order to initiate activity for the renewal of this permit, BNL requested a meeting on February 17, 1988 with NYSDEC to discuss the proper course of action. Since iron had been reported in concentrations in excess of the NYS DWS in we1ls downgradient of the landfill and $B N L$ was required to close its landfill in December, 1990, NYSDEC decided that a Consent Order would be required for continued use of the landfill instead of a permit renewal.

NYSDEC submitted a draft Consent Order to DOE-BHO for review in September, 1988. Between 1988 and 1990 , several meetings occurred to discuss a variety of issues associated with the Consent order. The negotiating parties experienced difficulties integrating the proposed Consent Order with the requirements of the proposed IAG. Because of these difficulties, a revised Consent Order was not received prior to the December, 1990 landfill closure date.

Brookhaven National Laboratory ceased accepting wastes into the on-site landfill on December 18, 1990. Planning for this termination of operations began when discussions were held with Brookhaven Town Officials in April, 1990. In July, 1990, all BNL nonradioactive, nonhazardous solid waste was taken to the Town landfill as a test program to assess manpower and equipment requirements.

In November, 1990, the Laboratory's long-term recycling program for computer paper, waste oil, and metals was expanded to include white office paper and cardboard. Efforts were also initiated to procure receptacles for use in the BNL apartment area to begin metal and glass container recycling. While a temporary vendor has been obtained for recycling of construction/deme iftion debris, the Laboratory is continuing to explore permanent vendor sources. In addition, asbestos waste will be removed by a licensed disposal firm under existing task order agreements.

Nonradioactive, nonhazardous, nonrecyclable solid waste will be disposed of at the Brookhaven Town Landfill as of December 19, 1.990. The Laboratory had obtained a verbal commitment on this agreement from the Solid Waste Commissioner and is pursuing formalization of a five year agreement. Brookhaven National 
Laboratory will pay the same tipping fee as lown residents, which is currently $\$ 45$ per ton. The increased costs of disposal have been factored into Plant Engineering's FY 1991 operating budget.

\subsection{National Emission Standards for Hazardous Air Pollutant Authorization Applications}

Brookhaven National Laboratory possessed seven NESHAPs authorizations for facilities under construction or that have been built since 1985. In 1990 , seven additional facilities were reviewed for NESHAPs compliance as required by $40 \mathrm{CFR}$ 61.94. ${ }^{32}$ These facilities were found to contribute site perimeter doses that were substantially less than the $0.1 \mathrm{mrem} / \mathrm{yr}$ effective dose equivalent that requires formal authorization to construct or modify from EPA Region II. A11 other facilities had construction dates which predate 1985. The site boundary dose from all facilities as calculated using CAP88 for CY 1990 was 0.07 mrem $(0.0007 \mathrm{mSv})$. The collective dose over an $80 \mathrm{~km}$ radius was $1.3 \mathrm{z}$ :rson-rem (0.013 person-Sv)

During 1990, several activities involving dispersable airborne radio. nuclides were reviewed for NESHAPs compliance and were found to be exempt from filing requirements. These include the evaporation of STP holding pond water; the aquifer restoration project; sludge drying operation at Building 445; a laboratory fume hood involving tritium in Building 318; Plasma Mass Spectroscopy lab operation; pharmaceutical labeling process in Building 490; and fluorine-18 use at the PETT VI facility. A brief description of the source and documentation that the dose does not exceed 0.1 mrem has baen provided in the 1990 annual report to EPA.

The risk assessment program CAPB8 was used to evaluate the dosimetric impact of 1990 radioactive airborne effluent releases. Several of the radioisotopes which were released from BNL facilities in 1990 do not appear in the CAP88 nuclide library. Therefore, analogue nuclides whose selection was based on similar radiological and chemical properties were substituted where necessary. The doses resulting from the inclusion of these analogues were then adjusted using the afpropriate dose conversion factors of the original missing species. Brookhaven ivational Laboratory 19,90 annual wind rose data and revised 1990 population data were input into the CAP88 program. The agricultural parameters used were those provided by CAP88. Brookhaven National Laboratory did not attempt to use site specific data that were previously provided as part of the 40 CFR 61.07 Application to Modify 2 NL Building 705.

\subsection{Audits and Appraisals \\ 5.6.1 Tiger Team Assessment General}

In March and April of 1990 , the DOE conducted a comprehensive Environmental, Safety, and Health (ES\&H) and waste operations Assessment at BNL. The team, labelled by DOE as a Tiger Team, consisted of about 50 ES\&H professionals that had been assembled from a combination of DOE, contractor, and consultant organizations. Compliance wsth applicable federal, state, and local regulations; applicable DOE orders; and internal BNL requirements were assessed. In addition, the assessment included an evaluation of the adequacy and effectiveness of the DOE and site contractor, AUI, management, organization, and administration of the ES\&H programs at BNL. A complete documentation of the findings of this assessment has been published. ${ }^{15}$ In the area of compliance with environmental and waste management concerns, there were 37 findings dealing with the lack of 
conformance to Federal and State laws and regulations, County codes, DOE Orders, and 27 findings in which best management practices were not attained. The key concerns in the environmental area was the lack of adequate hydrogeological characterization and inadequate control of activated material.

Four activities at BNL were directly affected by the assessment: The Aquifer Restoration Project was halted in response to requests from NYSDEC and the Tiger Team to halt the activity until concerns of NYSDEC were addressed; the installation of 26 additional ground water survelllance wells was terminated until a well construction protocol that would meet DOE, EPA, and NYSDEC concerns was finalized; the MRR was taken off-line because organic contamination in the cooling water supply wells (pre and post use as cooling water) exceeded NYSDEC discharge limits for release to a recharge basin; and the ground water surveillance sampling program was suspended in the areas of the HWM facility, Current Landfill, and Former Landfills because sampling personnel had not completed training required due to BNL's listing on the National Priorities list.

Brookhaven National Laboratory reviewed the findings, responded to the technical accuracy of the findings, and developed an arcion $\mathrm{plan}^{34}$ which was submitted to the DOE in October, 1990. This action plan provides the milestones and schedules to address the findings of the Tiger Team. Regarding the immediate impacts of the Tiger Team, a new source of water for the MRR was found that allowed restart of the reactor in the third quarter of 1990. The S\&EP field sampling personnel were trained and the program resumed in late June of 1990. The Aquifer Restoration Program has yet to restart. A ground water consultant was hired to evaluate the questions raised by the NYSDEC and the Tiger Team but a final report was not issued in 1990. Finally, a ground water surveillance well installation protocol was finalized, However, the ground water monitoring program upgrades were not restarted because the decision was made to coordinate ground water upgrades with ground water investigation work that would be required under the IAG.

\section{6 .2 Inspector General}

In the first quarter of 1990 , the Office of the Inspector General audited the facility for environmental compliance. The objectives of the audit were to determine whether the DOE, Chicago Operations Office, and BNL had established and implemented policies, procedures, and practices for:

- Complying with the Resource Conservation and Recovery Act (RCRA) and the Comprehensive Environmental Response, Compensation, and Liability Act (CERCLA); and

- Identifying the need for and obtaining necessary permits and monitoring compliance with the permits.

A draft report was issue to the DOE in November of 1990.47 The audit identified three areas where improvements were needed:

Documentation of training provided and needed for job performance; Evaluation of RCRA/CERCLA compliance due to sewer line loss issues; and 
- Bettex policies, procedures, and controls to obtain and comply with permits.

The items identified by the Inspectcr General report are also documented in the Tiger Team Assessment. ${ }^{16}$ The action plan developed for the Tiger Team ${ }^{34}$ should address the issues raised in this audit.

\subsubsection{EPA Region II 40 CFR 61 Subpart H NESHAPS Compliance Inspection}

In the third quarter of 1990, EPA Region II conducted an on-site inspection of facilities and records relative to compliance with 40 CFR 61. Subpart H NESHAPs radionuclide air emissions. The inspectors toured the site and visited the four locations which were found not to be in compliance in 1989, verified the documentation for these facilities, discussed issues regarding use of CAP88, and reviewed evaluations that were performed on facilities or operations where radioactive airborne effluents resulted in a dose of less than 0.1 mrem $(0.001$ $\mathrm{mSv}$ ) to the maximum exposed individual. No notices of violations were issued as a result of this inspection.

\section{$5.7 \quad \underline{0 i 1 \text { Spills }}$}

During 1990, S\&EP responded to a total of 29 environmental releases of oil or chemicals. Twenty three of these incidents involved small quantities of material which were contained on asphalt, concrete, or impervious surfaces. Cleanup procedures were instituted and there were no environmental impacts as a result of these occurrences. Six of these releases required EPA, NYSDEC, and SCDHS notification. These spills were cleaned up and the associated contaminated absorbent and affected soil were sent off-site for disposal of in an approved manner.

\subsection{Review of Engineering Design Drawings}

New construction and facility renovation projects need safety and environmental reviews from conceptual design through completion of construction and prior to final occupancy to assure that basic safety and environmental protection requirements are provided. As part of the review team, the S\&EP EP staff members review these proposals and plans to assure that potential hazards are identified and potential environnental impacts are analyzed. In addition, these reviews are conducted to ensure that all necessary permits are obtained and that new construction or modifications comply with federal, state, and local regulations. In CY 1990, between 25 to 30 of these types of reviews were performed.

\subsection{Major Petroleum Fast lity (MPF)}

The NYSDEC is required by Article 12 of the Navigation Law ${ }^{48}$ to protect and preserve the lands and waters of New York State from all discharges of petroleum and specifically from major petroleum storage facilities. In order to fulfill this responsibility, all major petroleum storage facilities are required to be registered with the NYSDEC and must have a license to operate. The license is contingent on several conditions. In addition to general ground water monftoring conditions, specific conditions may be included from year to year. 
All major petroleum storage facilities are required to install ground water monitoring wells. The license has general conditions which include regular testing of monitoring wells for floating and dissolved product. Typically the testing for floating product can be performed by the owner of the facility; however, testing for dissolved product is required to be performed by a NYSDEC certified laboratory.

The BNL CSF supplies steam for heating and cooling to all major areas of the Laboratory through an underground distribution system. The MPF is the storage area for the fuels used at the CSF. Brookhaven National Laboratory operates its MPF under a license (No, 01-1700) which is issued by the NYSDEC and renewed annually.

Five ground water wells, one upgradient and four downgradient, are used for regulatory compliance monitoring of the BNL CSF. The upgradient well is designated as Well ID 66-08 and is located approximately 1100 feet north of CSF Tank 6:1A. The four downgradient wells were installed by R\&L Drillers at the NYSDEC specified locations in the vicinity of the CSF during the week of June 28 through July 6,1989 . These wells are designated as 76-16,76-17, 76-18, and 76 19. Their approximate locations are shown in Figure 33. The well casings are constructed of polyvinyl chloride (PVC) and are four inches in diameter. These wells have PVC screens which are 20 feet in length. At the time of installation, depth to water in these wells ranged from approximately 30 to 35 feet. The NYSDEC was informed of the drilling schedule and sent a representative to observe the installation process for one of these monitoring wells.

In accordance with conditions of our MPF license, regulatory compliance samples were collected from these wells twice during 1990 and submitted to a NYSDEC certified laboratory. The NYSDEC requested analyses for these wells to include volatile organics by EPA Methods 624 and 625 , and petroleum products in water by NYSDOH Method 310-13. The analytical results are summarized in Tables 70 - 71 and discussed in section 3.3.8.2. The analytical results were transmitted to the NYSDEC. Another condition of the MPF license is that these wells be monitored monthly for floating product. This condition was fulfilled during CY 1990 and no floating product was found in any of these wells. In addition to these compliance samples, these wells are also monitored several times a year as part of the BNL routine environmental monitoring program.

\subsection{Safe Drinking Water Act (SDWA)}

During 1990, four on-site wells were used to provide potable water at BNL. Routine monitoring frequency of these wrells exceeds the minimum requirements prescribed by the SCDHS. The samples ace analyzed by a contractor laboratory using standard methods of analysis. This laboratory is a state approved commercial drinking water laboratory. The results are submitted to the SCDHS as required by Chapter I, Part 5 of the NYS Sanitary Code.

One of the SCDHS monitoring requirements includes quarterly analysis of potable well water samples for VOCs. The fourth quarter VOC analyses indicated the presence of TCA in Potable Well 4 at a concentration above the NYS standard of 5 parts per billion. The well was voluntarily removed from service. 
Prior to obtaining these results, BNL was concerned with the increasing concentrations of TCA observed in this well during previous quarterly sampling. In an effort to further investigate this, a testing program was developed to evaluate the abllity of the existing processes at the BNL WTP to remove organic compounds. To ensure the merit of this testing program, the proposed protocol was discussed with a representative from the SCDHS.

The testing program was conducted in October, 1990. A package was prepared describing the test protocol and analytical results, and submitted to the SCDHS for their review and evaluation. A decision from the SCDHS is anticipated to be issued during the first quarter of 1991.

\subsection{NEPA Program}

In 1990, the Laboratory showed its strong commitment to full compliance with NEPA and DOE Order 5440.1D through the hire of a dedicated NEPA compliance officer. The BNL NEPA Policy continued to take shape with draft protocols addressing construction, operation, capital improvement, and research projects iss'ed in June and October. To further promote NEPA compliance, Dames and Moore was contracted to prepare an Occupational Health and Safety Guide which would include procedures for NEPA compliance. The first draft of this guide was revlewed in October.

Environmental evaluations were completed for 166 projects in accordance with the NEPA protocol. Of these, 44 were considered minor actions requiring no additional documentation and 122 had Environmental Evaluation Forms completed for submission to DOE.

\subsection{Superfund Amendments and Reauthorization Act (SARA) of 1986}

The SARA regulations require that BNL compile and submit Tier I reports to the New York State Emergency Response Commissioner, the Suffolk County Local Emergency Response Committee, and the responding fire organization. For BNL, the responding fire organization is the S\&EP Fire and Rescue Group. For CY 1990, BNL submitted to these groups the Tier I report. This report contained the maximum and average daily amounts for all chemicals, determined from inventory and purchasing records, which fall into the following categories: physical hazardous, classified by type as fire, sudden release of pressure or reactivity, and health hazards, classified by type as immediate (acute) and delayed (chronic). Bronkhaven National Laboratory is not required under the SARA regulations to submit a Tier II report unless requested by an outside agency. In 1991, New York State requested that this report be submitted. Brookhaven National Laboratory complied with this request.

\subsection{Interagency Agreement (IAG)}

On December 21, 1989, BNL was included as a Superfund Site on the National Priorities list. Subsequently, a draft interagency agreement, also referred to as a Federal Facilities Agreement, was negotiated among the U.S. DOE, the U. S. EPA, and the NYSDEC. The IAG was written to insure compliance with CERCLA, the corrective actions requirements of RCRA, the National Environmental Policy Act 
(NEPA), and corresponding NYS regulations. In particular, the IAG is intended to insure that environmental impacts associated with past ar.d present activities at BNL are thoroughly and adequately investigated so that appropriate response actions can be formulated, assessed, and implemented. Although negotiations for this agreement were completed in 1990, al1 parties have yet to sign the document. Due to deadlines agreed to in the IAG, BNL proceeded with preliminary work as if the document were adopted by each agency. The BNL site currently has 24 Areas of Concern (AOC) that have been grouped into seven operable units as defined in the IAG.

In 1990, the draft Site Baseline Report was issued for review and comment. This report provides a historical review of the information available on these areas of concern. Remedial investigation and feasibility study profect plans for the area including the CSF, Building 650 Sump and Sewer System Line-Loss were initiated. Also planning for removal actions began for the decontamination and decommissioning of three 100,000 gallon above-ground radioactive waste storage tanks, sampling and removal of various unclerground storage tanks, and the sampling plus removal, if necessary, of various industrial cesspools. Finally, EPA and NYSDEC received the following reports for review: Solid Waste Management Unit Classification Report, Historical Site Review Work Plan, Sampling and Analysis Results for the Underground Storage Tank (UST) Project and the Cesspool Sampling and Analysis Plan.

\subsection{Resource Conservation Recovery Act (RCRA)}

The HWMF is operating in interim status under Part 6 NYGRR373 Permit ( 40 CFR 270.10). Brookhaven National Laboratory is responding to a Notice of Incomplete Application (NOIA) from the State of New York and will be submitting a revised application in 1991. Fire protection constitutes the major RCRA compliance issue identified as part of the DOE Tiger Team RCRA inspection. There is concern that an insufficient supply of water in the area exists to successfully fight a fire at the facility. The long-term solution is the construction of a new facility which is currently in the design phase. The short-tarm solutions are being investigated and include: fire protection upgrades to the existing structures, installation of two stationary 5,000 gallon water tank, and the procurement of small waste storage sheds that contain fire suppression systems. The Tiger Team audit also identified containers that were not appropriately dated or labeled and a small amount of uncharacterized waste. These items have been addressed through procedural changes and analytical analysis of the material. In the 90-day accumulation areas, the issue of inadequate labeling and dating of the waste was also observed. Communications to the Departments/Divisions that describes proper labeling and dating practices were issued. 


\subsection{ENVIRONMENTAL ASSESSMENTS}

\subsection{Biomonitoring of the STP Liquid Effluent}

Analysis of the STP effluent, which discharges into the Peconic River, for water quality and radioactivity is an integral part the laboratory's environmental monitoring program. Biomonitoring, which monitors the impact of BNL effluent on aquatic biota, was added to the base monitoring effort in 1987 . The results of the 1990 work are presented in this report.

The type of species used in the 1990 monitoring effort ranged from sensitive species (brown or rainbow trout) to hardy species (blue gills, large mouth bass, golden shiner, etc.). The latter species are also endemic to Long Island freshwater bodies and are considered as local game fish. The experimental set up consisted of a once through flow system of the effluent through an aquarium which contained the fish. Dissolved oxygen and temperature was monitored daily. Integrated water samples were collected in conjunction with fish sampling. Data collected in 1990 paralleled observations made in 1987, 1988 and 1989 , in that there is short term rapid intake of the principal radionuclide cesium-137 that reaches equilibrium when the concentration in fish flesh is about 40 times the concentration found in the water. No differences were found between the trout species and the endemic species except that variations in dissolved oxygen and temperature impacted on uptake characteristics of the trout species (decreased uptake during summer months). Effluent characteristics seemed to promote good growth rate, thus testifying to the viability of the efflueint stream.

\subsection{Department/Division Safety Assessments}

According to BNL policy, periodic safety assessments of all Departments and Divisions are performed by members of the S\&EP Division. Applying the most current guidelines, standards and rules, the purpose of these assessments is to detect and assess programmatic deficiencies in the Department's/Division's environmental protection, occupational safety, and health programs. The EP Section's participation in such assessments is part of a multi-disciplinary task force. The following guidelines were used by the EP Section staff in conducting such assessments:

1. Evaluating Supervisor's knowledge of EP requirements, such as applicable regulations, available training, contacts for assistance in compliance issues.

2. Verification of compliance with federal, state, local, and BNL Safety Manual effluent discharge limitations.

3. Identification of effluent sources and location of potential contamination areas.

4. Evaluating effectiveness of effluent treatment and control methods. 
5. Evaluating status of appraisal findings as defined by DOE, State, County, and BNL appraisals.

The abova criteria were used to assess the following Departments and Divisions in 1990:

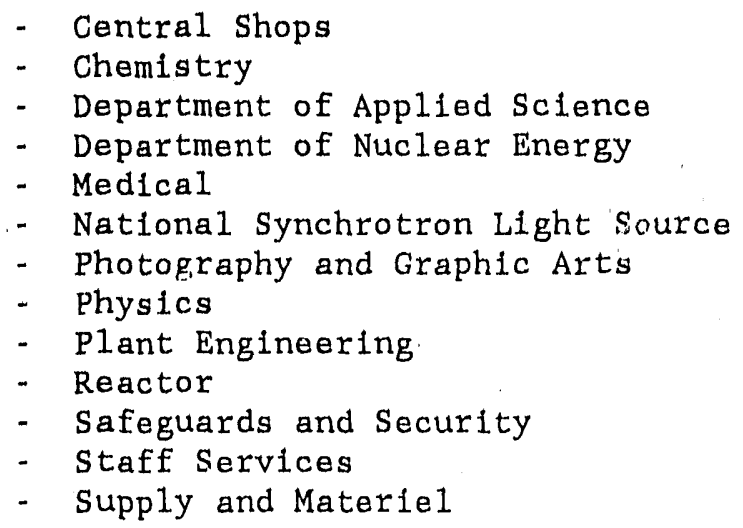

The main focal points of this assessment program during 1990 were compliance with Suffolk County Article 12, Toxic and Hazardous Materials Storage and Handling Controls, NYS Air Emissions Standards, and issues that affect the Laboratory's SPDES permit. Each assessment resulted in a report that identified areas of concern that were conveyed to the respective Department/Divisions as observations, which are isolated or infrequent occurrence items, or recommendations, which are based on observations that are serious, repetitive, and therefore considered programmatic in nature.

\subsection{Photographic Arts Buildings Liquid Effluent Sampling and Analysis}

In response to a SCDHS request, BNL conducted sampling and analysis of liquid effluent obtained at P\&GA Building effluent outfalls (B1dgs. 118 and 197) into the BNL sanitary sewer system. Selected organic and metal analyses were performed based on the SCDHS recommendations. Samples were collected using an automated sample collection system which collected a $15-20 \mathrm{ml}$ aliquot of waste every 15 minutes over the course of an eight hour work day. Each building uccupant was instructed to have all equipment within the building operating at the maximum output. No organics were detected in these samples and silver was the only metal detected that exceeded the NYS Code of Rules and Regulations 703.6 standard which SCDHS uses in their evaluations. Although silver concentrations at the STP did not exceed SPDES permit requirements, it was determined that best management practice would require state-of-the-art silver recovery units to be installed in each facility and that concentrated chemical developing solutions be collected and disposed of through the BNL HWMG. Several activities were completed during 1990 with regard to the P\&GA effluents: State-of-the-art silver recovery units were installed; Arrangements were made with a vendor for off-site disposal of concentrated photographic wastes; and Discharges from photoprocessing equipment in Bullding 197 were piped to a drum storage area to facilitate collection of these effluents. Similar modifications will be made to the photoprocessing equipment in Building 118 in 1991. 


\subsection{CSF Leaching Pit}

On November 6, 1989, excavation began at a location south of the CSF, (Building 610), for the installation of a 1000 gallon underground propane tank. Although current utilities maps indicated that there were no utility lines underground at this location, the backhoe encountered an eight inch vitreous tile pipe approximately three to four feet below grade. The pipe cracked upon impact of the backhoe and approximately one to two gallons of what appeared to be Number 6 oil leaked onto the ground. A section of pipe was cut and removed from the excavation. There appeared to be a small quantity of residual oil in the bottom of the pipe. The section of pipe and oil contaminated soil was placed into a DOT approved 55-gallon drum for appropriate disposal.

In an effort to determine the purpose that this pipe had served in the past and to determine what the pipe had been connected to previously, plant Engineering personnel obtained design drawings of Building 610 dating back to the $1960^{\prime}$ 's and 1950's. Based on their review of these drawings, it was learned that the pipe had connected floor drains in Building 610 to a leaching pit.

The backhoe was used to locate the cover to the leaching pit, which appeared to be less than one foot below grade. The surface soil around the cover was excavated to facilitate its removal. The cover of the leaching pit is made of concrete, approximately twelve inches thick, and has a standard metal manhole in it. The leaching pit has an outer diameter of approximately nine feet. The walls of the leaching pit were constructed using concrete cinder blocks lying on their side.

Upon removal of the cover, it was discovered that the pit contained a thick black tarry material which was similar in appearance to Number six oil. A sounding stick was used to estimate the pit to be eleven feet deep and to estimate the material depth to be nearly 53 inches. A sample of the material was collected and submitted to the S\&EP Analytical Chemistry Laboratory for PCB analysis. The results indicated that the $\mathrm{PCB}$ concentration was below the instrument detection limit of $10 \mathrm{ppm}$.

The EPA, NYSDEC, and SCDHS were notified on the day of the discovery. The spill report numbers, issued respectively, are 19776, 8907794, and 1989-1164. SCDHS inspected the site on November 8 th and NYSDEC on November 13 th. A licensed $r$ izardous materials hauler was contracted to pump the contents from the leaching pit to a trailer tank at the CSF pending the finalization of the disposal plans.

Additional samples of the material were collected and submitted to an offsite EPA approved laboratory for priority pollutant analysis. The results of analysis indicate that the material is similar to Number Six fuel oil but does contain some hazardous constituents as does virgin Number Six fuel oil. The analytical results were submitted to the NYSDEC for a determination on whether or not the material and thus the surrounding soil is hazardous.

In February, 1990, DOE-BHO determined based on the analysis of oil samples from the pit that the soil in the pit was contaminated with Number six fuel oil. The NYSDEC Region I office also concurred with that determination. As a result, NYSDEC had no objections to the disposal of the oil-soaked soil and oil-soaked 
concrete blocks which were the construction material for the leaching pit at the Town of Brookhaven Landfi11. NYSDEC provided expeditious approval of the energency waste transporter permit necessary for this disposal.

A contract was initiated with Marine Pollution Control to excavate the soil and debris from the leaching pit. The EPA and NYSDEC were provided with ample notification of the proposed subsequent soil and debris removal activities. The excavation was initiated on April 18, 1990. The extent of excavation of soils from the pit was initially based upon visually contaminated soil. A representative from NYSDEC who was present for the excavation also indicated that oil and gas spills are typically remediated based on visual criteria.

After the pit appeared clean based upor visual inspection, samples of soll were collected from the bottom of the pit and tested based on odor criteria to ensure that no discernible petroleum-type odors were present. On April 19, 1990, representatives from BNL, DOE-BHO, and NYSDEC agreed that sufficient soil and debris was excavated from the leaching pit and that the cleanup criteria established was met. The ultimate dimensions of the excavated hole were approximately 20 feet deep by 20 feet in diameter. The total volume of soil and debris excayated from the pit was approximately three hundred cubic yards. Clean sand soil from another part of the Lab was placed into the hole.

Future investigation of the soil and ground water in the vicinity of the leaching pit will be addressed unde:r the Remedial Investigation/Feasibility Study (RI/FS) for the CSF which is anticipated to begin in 1991. It has also been proposed thac soils in and around the pit will be analyzed as part of the CSF RI for benzene, toluene, and xylene, since these are typical components of petroleum-based products. The ground water in this area will also be further characterized during the $\mathrm{KL} / \mathrm{FS}$.

\subsection{Discharge of Resin Column Regeneration Water to Recharge Basin HT (006)}

Ultra-pure demineralized water is used as the primary cooling fluid in BNL accelerator facilities. This medium is produced by passing domestic water through ion exchange column resins to remove impurities. Periodically, these resin: are regenerated by flushing the columns with an acidic/basic solution which, until 1990, was discharged into the recharge basins that received the normal cooling water outfal1. However, in December of 1989 , one such discharge reacted under ambient conditions and the metals in solution precipitated out into the bed of the recharge basin. The incident was reported to NYSDEC, EPA, and SCDHS; was reported in Unusual Occurrence Report 89-2950 and resulted in the collection of regeneration water from all sources within the AGS. A subsequent review of the regeneration process indicated that there were three facilities onsite that used this process: the AGS, the Tandem Van De Graaff, and the NSLS. The Tandem Van De Graaff and NSLS operations were small volume operations that were discharged into the sanitary system and occurred very sporadically over the course of several years. Metals concentrations at the STP appear to be unaffected by these releases. At the AGS, regeneration water was collected in mobil tank trucks that were processed by a waste hauler when the tank capacity was full during the first six months of 1990. Review of this practice led to the conclusion that waste disposal costs could be reduced by replacing fixed ion-bed 
exchange columns with removable columns that could be regenerated at an appropriate off-site location. Implementation of this solution commenced in the third quarter of 1990. Currently, regeneration water is collected for off-site disposal.

\subsection{Building 830 and Fire House Completion Reports}

In the middle 1980's, radioactive contaminated soil was removed from the vicinity of the former fire house (located just east of NSLS Building 725) and a leaking $D$-waste line at Bullding 830 . The work performed and the level of remediation was documented in reports generated during the period of initial remediation. Under the IAG, this work needed to be reviewed for completeness and adequacy and a completion report developed that outlined any additional sampling or activities that needed to be performed in order to close out these issues. A consultant firm was hired to perform this assessment for both former remedial actions. The reports were developed and concluded that additional sampling would be required to determine if further work would be needed. The reports were submitted to BNL's Office of Environmental Restoration (OER), NYSDEC, and EPA. The additional sampling will be performed as part of the RI/FS process. 


\subsection{SPECIAL PROJECTS}

\subsection{Status of Environmental Upgrades}

\subsubsection{General Plant Project (GPP) to Upgrade Underground Storage Tanks}

Brookhaven National Laboratory has a 1.1 million dollar program to bring its storage tanks into compliance with the requirements of Suffolk County Sanitary Code, Articles 7 and 12.41.43 The funding for this program, which consists of three phases, began in FY 1988. Although the program was anticipated to be completed by the end of FY 1990, additional funding will be required to complete the project.

The first phase of this program focused on 23 underground storage tanks (UST) used to store aqueous radionuclides. Most of these tanks had no future use and had been out of service for many years. In order to facilitate removal of the tanl:, samples of the liquids were collected where possible and analyzed. Six of these tanks were removed from the ground and three of these tanks were abandoned in place upon inspection and approval from the SCDHS. As a result of these actions, fourteen tanks were left in the program.

Two of these tanks were subsequently deleted from this program. These included a 550 gallon tank at Building 927 and a 2800 gallon tank at Building 462. The UST at Building 927 was installed in 1984 and used for temporary storage of cooling water from horn pumps. The water is stored for approximately one to two weeks while walting for analytical results to determine its final disposal. Frequency of use for this tank is based on research conducted in Building 927. It was last used in 1986 and is reported to have been used only a couple of times since it was installed. This tank was deleted from this program pending a determination of the applicability of Article 12 to emergency hold-up tanks and a determination from the AGS Department regarding its future use. The UST at Building 462 receives rinse water from a sink in which tools used in radioactive areas are washed. Once the tank is filled, the water is tested to determine the appropriate method of disposal. Based on historical analytical data, the contents of this tank are not considered to be radioactive waste. Therefore, this tank was also deleted from this project.

To evaluate the contents of the remaining tanks, a sampling and analysis plan was developed by an engineering consulting $\mathrm{firm}^{51}$ and was submitted to BNL in July, 1989. This plan was transmitted to both EPA and NYSDEC in Apri1, 1990. During the second quarter of 1990 an engineering consulting firm was contracted to characterize the tank sludges and provide recommendations for the proper removal of the tanks and their contents. The sampling program was conducted in June of 1990. Seven of the twelve tanks contained sludge sufficient for sampling. All tank samples were analyzed for Target Compound List organic compounds, Target Analyte List inorganic compounds, and cyanide using the EPA Contract Laboratory Program (CLi). In addition, all samples were also analyzed for radioactivity. All of the tank sludges were found to contain radioactivity arid RCRA hazardous constituents. The sludges may be considered characteristic mixed waste, however, TCLP analysis must be performed on the sludges in their final waste form in order to determine this. 
These USTs are included as one of the areas of concern covered under the IAG for: BNL. A11 future activities involving the treatability testing, removal, and disposal of the sludges and the tanks will be coordinated by the BNL OER. In accordance with the requirements of the IAG, EPA, and NYSDEC will also be involved with all future plans involving these USTs.

Additional activities were conducted during 1990 involving the five USTs which were found to contain insufficlent sludge for sampling. One of these tanks was a 550 gallon UST located at Building 527. Two of these tanks were under a parking lot at Bullding 463. The fourth tank was located in a concrete vault at Building 703. The fifth tank had previously been connected to Bullding 931 . It had been removed from the ground in 1988 in the presence of a representative from the SCDHS and was in storage pending characterization of its contents.

Since there is no eviderice of leakage from these USTs, and no response actions were anticipated under the IAG, these tanks constitute no-action AOCs. Section 760-1209.d of the Suffolk County. Sanitary Code Article 12 states that it is unlawful to use or maintain the existence of an abandoned underground storage facility. In order to achieve compliance with Article 12, the Laboratory notified DOE-BHO that these tanks should be removed. In accordance with the conditions of the IAG, EPA, and NYSDEC were appraised of the proposed removal of these tanks. Both agencies provided concurrence with this proposal in september 1990. The SCDHS was notifled of the schedule to remove these tanks in October, 1990. Representatives from the SCDHS witnessed various portions of the removal of these tanks. A soil sample was collected beneath each tank and analyzed for radioactivity, (tritium, gamma scan, and strontium-90) and target compound 1ist organics. The tanks were assumed to be radioactive and handled accordingly. The tanks will be cut up on-site and wipe samples from inside the tanks will be tested for radioactivity to determine the proper method of disposal. A completion report will be prepared in accordance with the IAG once all activities associated with these tanks have been finalized.

The Underground Storage facilities for gasoline and waste oil at Buildings 423 and 630 were replaced with double walled tanks and associated piping as part of the second phase of this program. The engineering design drawings and specifications for this project had been reviewed by the SCDHS during 1989. The tanks were subsequently replaced during the first quarter of 1990 . Representatives from the SCDHS witnessed various portions of the installation and testing of the new tanks and piping. In addition, seven underground fuel oil tanks were retrofitted with overfill protection equipment. A separate portion of this program also provided secondary containment for several sma11 outdoor aboveground storage tanks.

The third phase of this program will provide the upgrades necessary for any remaining outdoor aboveground storage tanks not completed during the previous phase. This project consists primarily of the replacement of two aboveground tanks used to store aqueous radionuclides at the BNL WCF (Building 811) and the installation of overfill protection on eight aboveground fuel oil tanks at the CSF (Building 610). Funding for this phase was received in 1990. Design work is in progress. Additional funding will be sought to upgrade indoor storage facilities. 


\section{1 .2 Closure of Cesspools}

The NYSDOH has made a determination that industrial cesspools are no longer an acceptable means of wasto disposal on Long Island. Discharges of this nature are prohibited by Title 6 of the New York Code of Rules and Regulations Part 751. as well as Suffolk County Sanitary Codes Articles $7^{41}$ and $1.2^{43}$ due to the sole source ground water aquifer. ${ }^{37}$

A number of buildings at BNL are still served by cesspools that discharge to ground watek. In order to address this issue, a study was conducted in 1985 to 1dentify and evaluate those buildings served by cesspools for connection to the central sanitary sewage system. Twelve bulldings served by cesspools were identified as potentially receiving industrial discharges from sinks and work areas. These facilities were included in a cesspool elimination project which would provide for connections to the site STP. Funding for this task was obtained through a line itern project.

Construction for this work began in August, 1989. Connection of all of these facilities to the BNL site STP was completed by the summer of 1990 . These cesspools are included on the list of AOCs under the IAG. The plans for sampling and closure of these cesspools were also developed during 1990. In accordance with the requirements of the IAG, these plans were submitted to EPA and NYSDEC for review and comment in November, 1990. Implementation of this effort will be coordinated by the BNL OER.

\subsubsection{Ground Water Upgrades - We11 Abandonment Program}

The ground water upgrades program was designed to permit the installation of new ground water surveillance wells, provide protective casings for existing wells, and abandon wells which were of no further use. In 1990, well abandonment and well-head protection were the components of the program that were initiated. To date, 41 wells have been abandoned according to crrent regulatory protocols under the IAG Agreement between DOE, EPA, and the NY.DEC. Aquifer Dri11ing and Testing Inc. and ERM Corp. are scheduled to abandoned an additional 28 on-site wells in 1991. In 1990, 22 wells received protective casings and/or riser pipes as necessary for the installation of the protective casings. Twenty-five well.s have also been slated to be retained for continued use as piezometers in BNL's EM program; these will be upgraded via the installation of protective casings and riser pipes as deemed necessary. Brookhaven National Laboratory's S\&EP Division will maintain an ongoing program of locating, identifying, and assessing the need to abandon old site wells which are discovered during routine sampling or field operations.

\subsubsection{Brookhaven National Laboratory CERCLA IAG and RI/FS}

In July, 1989, EPA proposed placing BNL on the National Priority List (NPL). In November, 1989, the action was finalized when the revised SUPERFUND List was published in the Federal Register. ${ }^{52}$ Following the 1isting of BNL on the NPL as a SUPERFUND site, the S\&EP EP Section has been coordinating with the OER group, S\&EP HWM section, activities that will need to be addressed in order to meat the requirements of the IAG and RI/FS program. Key areas where major roles are anticipated include: 
1. Review of sampling and analysis programs in support of characterization and assessment activities;

2. Installation and abandoning of monitoring wells on-site;

3. Participation in the tri-party IAG negotiations that began in November: between DOE, EPA, and NYSDEC as technical members;

4. Preparation of reports and protocols for review by DOE, EPA, and NYSDEC; and

5. Particlpating in site visits of the federal and state SUPERFUND Staff.

\subsection{Environmental Awareness Training}

Beginning in 1990, members of the EP staff began conducting Environmental Awareness seminars to first-line supervisors and upper level management of the BNL Departments and Divisions. Eight training sessions were conducted. The course provided the attendee with an overview of the most significant federal, state and local environmental regulations (i.e., NEPA, CWA, CAA, SDWA, WIld, Scenic and Recreational Rivers Act, Wetland restrictions, and Suffolk County Articles). The presentation also introduced the revised DOE environmental policy as outlined in the DOE Order 5400 series. Finally, the course presented BNL policy on effluent emissions and proposed changes in the ES\&H Standard.

\subsection{Summer Student Projects}

\subsubsection{Determination of Argon-41. Release Rate From the MRR}

In terms of overall dose equivalent recelved at the BNL site boundary, the most significant airborne effluent is argon-41. Argon-41 is an air activation product produced by operation of the MRR, which contributed $96.8 \%$ of the off-site collective dose equivalent resulting from BNL activities in 1990. As the major contributor to off-site dcse, the calculation of this source term is critical. Such a source term estimate can be calculated from the product of release rate (1.n C1/MW-hr) and active operating time. This release rate was calculated during a student project in which argon activity concentrations were measured using Marinelli beaker effluent gas sampling ond gamma spectroscopy techniques. The mean of sf.veral such measurements along with the knowledge of volumetric airflow rates in the MRR stack allowed for the construction of the appropriate power level-correlated Ar-41 release rate. This rate was found to be approximately 2 $\mathrm{Ci} / \mathrm{MW}-\mathrm{hr}$ and is now used to estimate the yearly argon source term resulting from MRR operation.

\subsubsection{Analytical Laboratory Instrument Calibration}

An additional student project was conducted in order to determine correction factors for two of the specific counting methods utilized in the BNL S\&EP Analytical Laboratory. The correction factors examined and calculated were the self-absorption factors involved in gross alpha counting on the Tennelec LB5100 and quench curve corrections necessary for accurate Liquid Scintillation 
Counting (LSC) on the Packard Tr1-Carb 2250CA LSC. As a result of the profect, self-absorption corrections for a particular sample beling analyzed for gross alpha activity can be determined by correlating the sampla's mass with a point on a plot of mass versus relative response. Likewlse, low-energy beta activity may now be measured more precisely with the quench curves developed for the various scintillation fluid volumes routiliely used in LSC analysis.

\subsection{Releage of Tritlated Water from the STP Emergency Hold-up Pond 非}

Low-level radioactive liquid waste undergoes volume reduction at the BNL WCF. This facility reduces volume in excess of 100 to 1 . The residue is removed, solidified, and appropriately disposed of as solid low-level radioactive waste. The distillate, which contains tritium, is released into the STP effluent from the clarifler under controlled conditions. Presently, distillate is transported from the WCF to one of the two lined emergency hold-up ponds at the STP. The distillate is released to the hold-up pond where evaporation and precipitation combine to both reduce the liquid effluent discharge and reduce the initial tritium concentration. Pond water is periodically pumped back to the STP and combined with the STP effluent for release at SPDES Outfall 001, the discharge to the Peconic River. The pump rate is determined by measurement of the tritium concentration in the pond and in the incoming STP waste stream. Administrative guidelines require that planned discharges to the Peconic River be smaller than $50 \%$ of the NYS DWS. In 1990, 68,100 1iters of distillate containing $0.85 \mathrm{Cl}(31.6 \mathrm{GBq})$ of tritium were placed into the STP Emergency Recharge Pond \#2. Controlled release of this material commenced in November and continued through early December 1990. Approximately $0.3 \mathrm{Cl}(11.1 \mathrm{GBq})$ was added to the effluent stream during this period. Tritium concentrations ente: ing the Peconfc River averaged $5400 \mathrm{pCi} / \mathrm{L}(200 \mathrm{~Bq} / \mathrm{L})$ or $27 \%$ of the NYS DWS. Releases during this period met both the NYS DWS and BNL administrative guidelines.

\subsection{Multimedia Environmental Pollution Assessment (MEPAS)}

As part of the 1987 DOE Environmental Survey, DOE developed and used the "Multimedia Environmental. Pollution Assessment" (MEFAS) model to determine the impact of the operations of DOE Faclilties on the environment. The model was used to rank the "Findings" or "Units" at each facility and subsequently for ranking the "Findings" on a DOE-wide basis using the MEPAS developed Hazard Potential Index (HPI). Currently, this methodology is being used for developing the priority rationale for the BNL Environmental Restoration Activities on a Fiscal Year (FY) basis. The principal components taken from this model to do the Priority rationale is the June, 1990 MEPAS ranking units and baseline risks as applied to the BNL Environmental Restoration Activities. This ranking is done for each FY and is specific to BNL.

\subsection{Off-site Ground Water Contamination}

Low-level concentrations of DCA, chloroform, TCE, and TCA, were detected in 1989 at a ground water survelllance well located in the southwest corner of the BNL site and screened at about 78 feet below grade. Brookhaven National Laboratory notified the SCDHS who, upon review of the data, embarked on a ground water survelllance survey of nearby private potable wells in an attempt to determine if the observed concentrations in the BNL survelilance wells were impacting the water quality of nearby residents. The SCDHS investigation identified five potable wells in the North Shirley area that had significant contamination of TCA. Brookhaven National Laboratory retained the services of Geraghty and Miller (G\&M) ${ }^{53}$ to investigate any possible connection between BNL and the contamination found in the private residences. The result of the SCDHS and G\&M studies were that ground water flow in the south west section of the site 
is primarily in the southern direction and that the source of the private water contamination was due to operations and waste disposal practices within a nearby Industrial complex that is located between the BNL boundary and the residences in question.

\subsection{Vandalisin of Ground Water Surveillance We11 18-01}

On October 25, 1990, S\&EP fleld sampling personnel found that Ground Water Surveillance Well 18-01. had been vandalized. The lock on the protective casing had been forclbly opened, the protective casing removed, and the dedicated well pumps located inside the well were found laying on the ground. A grab sample of the standing water indicated the possibility of a brown substance being added to the well. A baller was used to collect a standing water sample that was analyzed for fecal colfform, metals, volatile organics, and radioactivity. The only contaminant detected was toluene at a concentration of $18 \mu \mathrm{g} / \mathrm{L}$. These data indicated that a foreign substance was probably not added to the we11. Dedicated sampling equipment was next reinserted into the well. The well was purged following the standard protocol and samples were collected for analysis. No organics were detected on the second round of sampling. This incident has been reported to DOE under UOR $90-042.54$

\subsection{Investigation of Blue Substance in Recharge Basin HS (Outfal1 005)}

On October 8, 1990, Plant Engineering personnel noticed that the water in Recharge Basin HS had an unusual looking material that was blue/green in color and, although gelatinous in standing water, dissolved easily into solution upon mixing. Investigation into the observation revealed that when the recharge basin was sampled in September, there was no gelatinous materlal or blue/green color to the water. Further revlew determined that Hydro-Seed, a green colored grass seed/paper/fertilizer mixture, had recently been applied throughout the site and that PYLON Dye, a water tracing dye recommended for use by SCDHS, had recently been used to determine water sources that discharged into Recharge Basin HS. Testing of the recharge basin water, hydro-seed, and PYLON dye produced tentative results that indicated the Pylon dye was responsible for the observation. Because this material is a recommended substance for water tracing activities in Suffolk County and is believed to be environmentally benign, this observation, al though extensively investigated, did not const tute an unusual occurrence that required formal reporting to DOE. 


\subsection{COMPLIANCE SUMMARY}

Sections 5 and 6 of this report address in detall various aspects of BNL's efforts at maintaining the site in compllance with approprlate federal, state, and local regulations. This section provides a brief summary of information regarding existing facilities, operations, or environmental data which are not in compliance with environmental regulations.

\subsection{Ground Water Contamination in Excess of the DWS and 6 NYCRR Part 703}

Because BNL is situated on a sole source aquifer (Class GA as defined in 6 NYCRR 703), radiological and non-radiological environinental monitoring data obtalned from the ground water monitoring program are compared to the NYS DWS and concentration limits defined in 6 NYCRR 703.18 The following information lists the locations where ground water monftoring data indicates that these limits have been exceeded and provides a summary of the remedial actions that have been planned or are currently in place.

Location

Potable We1ls

\section{Status/Comments}

Potable well supply distribution systems serving over 3000 persons, such as those in service at $B N L$, are regulated by the NYSDOH. Regulatory requirements for these potable supply wells includes quarterly sampling for volatile organic compounds. In 1989, BNL Wells 10 and 11 were found to contain TCA at concentrations that exceeded the NYS DWS of $5 \mu \mathrm{g} / \mathrm{L}$. Both wells were removed from service. Carbon filtration was procured and installation of the filters commenced in 1990 at Well 11. Similar treatment is planned for Well 10.

In October of 1990, TCA concentrations that exceeded the NYS DWS were observed at Well 4. A testing program to verify the fourth quarter TCA concentration and to determine the TCA removal efficiency of the BNL WTP was conducted. Upon verification that Well 4 TCA concentrations exceeded the NYS DWS, it was removed from service. The test data for removal efficiency of TCA during routine processing of potable water at the WTP indicated that sufficient TCA was removed so that processed water from We11 4 had TCA concentrations less than the NYS DWS. These test data were provided to the regulators for a determination on the adequacy of the treatment method. A decision is expected in early 1991.

Soll and ground water in the vicinity of the CSF are contaminated with organic compounds which may require remedial action as a result of a 1.977 spill. Iron concentrations exceeded the NYS DWS at Wells 76-04 and 76-06. In addition, the following organic compounds were observed in samples from ground water surveillance wells in this area: TCA at Well 76-21, TCE at Wells 76-08, and 76-21; PCE at Wells 76-19, 76-05, 76-08, and 76-21; benzene at We11 76-21; ethylbenzene at We11s 76-04 and 76-21; toluene at We11s 76-04,76-06, and 76-08; and o-xylene at Wells 76-04 and 76-20. This area has been identified for remedial investigation under the RI/FS as Operable Unit 4. 
Location

HWMA

O1d Landfill

Cirrent Landfill

Peconic River/

Meadow March.

Upland Recharge

Area

Site Boundary

\section{Status/Comments}

Remediation for organic contamination detected southeast of the HWMA was suspended in 1990 due to concerns raised by NYSDEC and the DOE Tiger Team regarding the adequacy of the plume definition and capture zone of the remediation pumping wells. Survelllance Wells in the area indicated that the following organic compounds were present in segments of the ground water from this area at concentrations in excess of the NYS DWS: TCA at Wells 108-13, 88-04,98-02, 108-05, and 10812; PCE at Wells 88-04; and DCE at We11 98-02. In addition, strontium-90 exceeded the NYS DWS at Wells 88-04, 98-02, and 98-29. This area has been identified as requiring further remedial investigation under the RI/FS as Operable Unit 1.

The only parameter that was detected above NYS DWS was manganese at Wel1 97-05. All other parameters were below the NYS DWS. The former landfill has been identified for remedial investigation under the $: i / F S$ as Operable Unit 1.

Iron, manganese, DCA, benzene, ethylbenzene, and toluene are parameters that were observed in excess of the NYS DWS. Wells containing these parameters were: fron at We11s 88-01, 8 i $_{-12}$, $87-03,87-05,88-02,88-13,87-08,87-11,87-10,88-14$, and 88-15; manganese at We11s 97-14, 98-33, 98-34, 88-01, 88-12, 87-03, 87-05, 88-13,87-08, 87-11, 87-10,88-14, and 88-15; DCA at Wells 107-09, 88-13, and 87-11; benzene at Wells 87-08 and 87-11; ethylbenzene at We11 87-08 and toluene at We11 88. 13. The Current Landfill ceased operation in December, 1990 in compliance with the Long Island Landfill Law. This area has been identified for remedial investigation under the RI/FS as Operable Unit 4.

Iron concentrations in excess of the NYS DWS were observed at Wells 39-05, 47-02, 40-02, 47-01, and 47-04. Manganese was observed in excess of the NYS DWS at Wells 47-02 and 89-01. The Meadow Marsh-upland recharge and the STP in the area of the Peconic River areas of the site have been identified for remedial investigation under the RI/FS as Operable Units 6 and 5 , respectively.

I'richlorethane was detected at Wel1 83-02, a west sector well, and at We11 130-02 along the southwest boundary at concentrations exceeding the NYS DWS. Toluene was detected at Well 18 01 in excess of the NYS DWS. The results at Wells 83-02 and 18-01 were sporadic. Normal monitoring will continue in these areas. The area near well 130-02 has been identified for remedial investigation under the RI/FS as Operable Unit 1.

\subsection{SPDES Permit}

There are five recharge basins and one discharge to the Peconic River that are governed by the SPDES permit. In 1990, the following deviations from the permit requirements occurred: 
Location

Recharge

Basins

STP

Effluent

Cesspobls
Status/Comments

Samples collected from three of the five recharge basins had $\mathrm{pH}$ values below the MD. of 6,5. These include: one out of four samples collected from Recharge Basin HN (Outfall 002) had $\mathrm{pH}$ recorded at 6.0 ; one of five samples collected from Recharge Basin HS (Outfall 005) had pH measured at 6.0 ; and one of three samples collested from recharge basin HO (Outfall 003) had $\mathrm{pH}$ of 4.75. Ir addition, iron concentrations in excess of NYS discharge limits to ground water were observed at three of the five recharge basins.

There were five occurrences whure suspended solids exceeded the SPDES permit maximum daily value of $10 \mathrm{mg} / \mathrm{h}$. In addition, there was one instance where total colfform was measured above the SPDES discharge limit.

The line item project which provided connections to the site sanitary system for twelve bulldings previously served by cesspools was completed in 1990, Plans for sdmpling and closire of these cesspools were submitted to EPA and NYSDEC for their review in accordance with the requirements of the IAG .

\subsection{Radioactive Airborne Effluent Emissions Governed by NESHAPs}

In 1990, BNL emissions complied with 40 CFR 61 regulations regarding radioactive alrborne effluent releases. EPA Region II was notified that the Radiation Therapy Facility (BNL-489-01) had commenced operation and that seven operations had NESHAPs evaluations performed with the conclusion that a formal submission was not required. The site boundary dose resulting from BNL airborne emissions as calculated using CAP8 8 was $0.071 \mathrm{mrem}$. The radionuclide contributing the largest fraction of both the site boundary (87\%) and population dose (96\%) was argon-41. The release rate of this radionuclide was about $37 \% 1$ ess than in 1989. The reduced source term is the result of lower operation time and power level of the MRR in 1990. This information was tranimitted to both DOE and EPA in compliance with reporting requirements specifled in 40 CFR 61 subpart 94. Also, BNL recelved a facility compliance inspection in 1990 with no deficiencies reported.

The only facility that has the potential to release airborne radioactive effluents in concentrations that could result in a site boundary dose in excess of 0.1 mrem per year as a result of normal operations is the MRR release of argon-41. As stated in Section 7.3.1, the argon-41 produntion rate was measured and verified in 1990. The argon-41 source term for this facility is calculated based on power level and the measured production rate. This methodology represents an alternative method to define source term and as such, requires EPA Region II concurrence. The BNL Reactor division has requested funding to upgrade the air effluent monitoring capability at the MRR to comply with DOE ${ }^{23}$ and EPA $^{32}$ monitoring requirements. 
Other sources at BNL require pariodic confirmatinn. At the major facilities where routine monttoring occurs, the monttoring systems of the source term typlcally do not meet $40 \mathrm{CFR} 61$ requirements regarding sampling location and sample transport to the collection media. Most other small sources require identification and verification. The plan to identify these potential sources is outlined in the BNL Tiger Team Assessment Plan of Action. ${ }^{34}$

Brookhaven National Laboratory is in the process of notifying EPA Region II of the methods currently used to calculate and measure source terms used for compliance with $40 \mathrm{CFR} 61.32$

\subsection{State Air Laws}

During 1900, BNL evaluated a variety of air emission sources for the requfrement of Permits to Construct (PCs) and Certificates to Operate (COs) from the NYSDEC. The applicable regulations for these sources are the Codes, Rules, and Regulations of the State of New York, Title 6, Chapter III, Part 200, New York State Air Pollution Control Regulations. The number of sources and their status are described below:

\section{No. Status/Comments}

2

Certificates to Operate for two paint spray booths were canceled 1n. Apri1, 1990. Thess sources are no longer avall. able for use as they were destroyed in a building fire.

A request for renewal of two air emission sources at the Inhalation Toxicology Facility was made in September, 1990 and is currently undergoing review by the NYSDEC. The process continues to operate under the provisions of the Uniform Procedures Act.

Applications for PCs for two air emissions sources associated with a cleaning room were submitted in October, 1990. tor was submitted to NYSDEC in November, 1990. This unit was reinoved from operation in July, 1990.

11

Applications for COs for general processes, shaust, and/or ventilation systems were submitted to NYSDEC in December, 1990. These address a commitment made during the environment, safety, and health audit conducted by DOE Tiger Team in April, 1990.

\subsection{Suffolk Cownty Santtary Codes}

During 1990, BNL has made progress in bringing a number of storage facilities into compliance with the requirements of SCDHS. The applicable regulations 
are the Suffolk County Santery Code, Articles 7 and $12.41,43$ These storage facilities and their status are described below:

\section{No. Status/Comments}

1

Underground waste of tank was removed and replaced with a double-walled tank during Fabruary, 1990, Plans for the profect were reviewed by representatives from the SCDHS.

Underground gasoline storage tanks were removed and replaced with double-walled tanks and assoclated plping during February and March, 1990. Representatives from the SCDHS reviewed the plans and inspected various phases of this project.

Existing outdoor underground fuel ofl tarks were retrofitted with the addition of overfill alarm systems during March, 1990.

Aboveground outdoor tanks were upgraded with secondary containment.

Outdoor underground tank used to store fuel oil at Bullding 423 was removed in March, 1990 and replaced with a doublewalled tank and associated piping.

Outdoor underground tank used to store fuel oll at Building 32.1 was removed in June, 1990; the tank and excavation were inspected by a representative of NYSDEC.

Further activities were conducted during CY 1990 involving outdoor underground tanks, formerl', used to store aqueous $r$ adionuclides. Sludge samples were collected from seven of these tanks and analyzed by a contractor in order to determine the next phase of the project. The remaining tanks were free of sludge; four of these were removed in the presence of representatives from the SCDHS, one was removed in 1988. Additional details are discussed in Section 7.1.1.

3 Plans to upgrade three aboveground tanks used to store diesel fuel at the site maintenance facility were developed during November, 1990.

2 Overf111. protection equipment and alarms were installed on two large aboveground tanks at the CSF.

10 - 12 As part of Phase III of BNL's tank upgrade program, plans were developed to install overfill protection for aboveground fuel o11 tanks at the CSF and for an underground tank at the HWMF; replace storage tanks at the CSF and at the WCF. Additional detalls are discussed in section 7.1.1. 


\subsection{Safe Drinking Water Act (SDWA)}

The potable water at BNL is obtained from wells on-site. Four potable wells were used during 1990. These wells are routinely monitored; BNL's monitoring of these wells exceeds the minimum requirements prescribed by the SCDHS. The samples are analyzed by a contractor, laboratory using standard methods of analysis. This laboratory is a state approved commercial drinking water laboratory. The results are submitted to the SCDHS as required by Chapter I, Part 5 of the NYS Sanitary Code.

One of the SCDHS monitoring requirements includes quarterly analysis of potable well water samples for VOCs. The fourth quarter VOC analyses indicated the presence of TCA in Potable Well 4 at a concentration above the NYS standard of 5 parts per billion. The well was voluntarily removed from service.

Prior to obtaining these results, BNL was concerned with the increasing concentrations of TCA observed in this well during previous quarterly sampling. In an effort to further investigate this, a testing program was developed to evaluate the ability of the existing processes at the BNL WTP to remove organic compounds. To ensure the merit of this testing program, the proposed protocol was discussed with a representative from the SCDHS.

The testing program was conducted in October, 1990. A package was prepared describing the test protocol and analytical results, and submitted to the SCDHS for their review and evaluation. A decision from the SCDHS is anticipated to be issued during the first quarter of 1991.

\subsection{Toxic Substance Contral Act (TSCA)}

\subsubsection{TSCA Program at BNL}

The Toxic Substance Control Act (TSCA) regulates the use and disposal of specific substances, one of which is PCBs. The TSCA requirements include labeling, inspections, record keeping, immediate notification and cleanup upon discovery of spills, and proper disposal. In February, 1990, S\&EP issued the BNL PCB Program Requirements to all Departments and Divisions. This program formally identifies the activities that Departments and Divisions must perform to ensure that their facilities are in compliance with the requirements of TSCA. At this time the Departments/Divisions were requested to review, verify, and update previous inventories of $\mathrm{PCB}$ equipment in Buildings under their jurisdiction. S\&EP personnel visited the various Departments to verify and inspect their equipment. A database was developed by S\&EP to enable tracking of all Department/Division PCB equipment. This will be updated as changes to individual inventories are reported. In addition, the Annual PCB Report for CY 1989 was prepared in accordance with the requirements of TSCA. This report is retained on file at S\&EP Division. A copy is also submitted to DOE-BHO.

\subsubsection{PCB Consent Order}

In October, 1984, the Laboratory received off-specification military fuels containing PCBs in excess of $50 \mathrm{ppm}$. The Laboratory blended this material with other fuel resulting in 286,000 gallons of ALFs having a PCB concentration of 
approximately $80 \mathrm{ppm}$. On January 21, 1986, the EPA Region II formally approved BNL's plan to incinerate this material at a $10 \%$ firing rate (concentration of 8 ppm) in BNL's high-efficiency Boilers, 4 and $5 .{ }^{46}$ The material has remained in storage since this time awaiting NYSDEC authorization to burn it.

Several activities occurred during 1990 related to the PCB contaminated fuel in storage at the CSF. In January, 1990, NYSDEC issued a letter to DOE-BHO indicating that they were going to modify the certificates to operate CSF Boilers 4 and 5 to reflect the current fuel usage of Number Six oil and ALF free of PCBs. This modification revoked the special conditions previously agreed to for burning PCB contaminated fuel and became effective February 9, 1990. The NYSDEC also issued a revised Order on Consent for the incineration of PCB contaminated fuel at the CSF in February, 1990. While it addressed many of the previous concerns, there are still legal issues which were not resolved by the end of 1990 .

Discussions and negotiations also continued with EPA during 1990. One of the conditions of EPA's formal approval to incinerate the PCB contaminated fuel was that it te initiated and completed within specific time frames. Due to the lengthy period of negotiating a Consent Order with NYSDEC, this time frame expired which necessitated BNL to request an extension. Brookhaven National Laboratory received an extension of time to begin incineration of the fuel from EPA in Apri1, 1990. During the fall of 1990 it was proposed to EPA and NYSDEC that the fuel be disposed of as a removal action under the proposed RCRA/CERCLA IAG. In addition, BNL requested a modification to the January 21, 1986 approval from the EPA to incinerate the PCB contaminated fuel. Brookhaven National Laboratory proposed incineration at a fuel feed rate of $100 \%$ as opposed to the $10 \%$ rate as set forth in the Federal Facilities Compliance Agreement and Section 761.60 of TSCA. The basis for the request was that the results of stratified fuel samples collected during 1989 indicated that the concentration of PCBs remaining in the fuel ranged from 10 to $32 \mathrm{ppm}$ which is less than the $50 \mathrm{ppm}$ concentration specified in Section 761.60 .

\subsection{Resource Conservation Recovery Act (RCRA)}

\subsubsection{Tiger Team Assessment}

The HWMF has one major compliance concern, which was noted on the Tiger Team Assessment. There is an insufficient volume of water to fight a fire as required under RCRA (40 CFR 265.32(d)). This problem is being addressed by investigating the possibility of installing two 5,000 gallon tanks that will hold water for fire fighting. These tanks will be on an automatic feed, which will insure a constant supply of water. Additionally, the HWMF has purchased hazardous waste storage sheds that are protected with a fire decection/ suppression system.

The HWMF did have some minor compliance concerns. During the Tiger Team Assessment and on other audits, containers were found without labels and dates [40 CFR 262.34(a)]. This problem has been eliminated by the issuance of a new standard operating procedure, "Inspection Plan Procedure for the Hazardous Waste Management Facility" (HWM-001). This procedure instructs the inspector to check each container once a week to insure that the containers comply with the labeling 
requirements. The HWMF also had a small quantity of waste that was uncharacter ized (40 CFR 262.11). This waste has been analyzed, and it was determined that the waste was only radioactive and not a RCRA waste.

\subsubsection{0-Day Accumulation Areas}

The 90-Day Accumulation Areas were inspected during the Tiger Team Assessment and during Tier II inspections. The same type of compliance deficiency was found. Some generators of hazardous waste place waste in their 90-Day Accumulation Area without the words "Hazardous Waste", and without the date it was placed into the 90-Day areas [40 CFR 262.34(a)]. Guidance has been provided on numerous occasions from the Directors office on this subject.

\section{8 .3 RCRA Permits}

The Part 6 NYCRR373 Permit (40 CFR 270.10) is still in interim status. Brookhaven National Laboratory has received a NOIA from the State of New York. The permit is currently being revised to answer the concerns of the NOIA. The Permit Application should be ready for resubmission by July 1, 1991.

\subsection{Comprehensive Environmental Response, Compensation Liability Act (CERCLA)}

On December 21, 1989, BNL was included as a Superfund site on the NPL. Subsequently, a draft IAG, also referred to as a Federal Facilities Agreement, was negotiated among the U.S. DOE, the U.S. EPA, and the NYSDEC. The IAG was written to insure compliance with the CERCLA, the corrective action requirements of the RCRA, the NEPA, and corresponding NYS regulations. In particular, the IAG is intended to insure that environmental impacts associated with past and present activities at BNL are thoroughly and adequately investigated so that appropriate response actions can be formulated, assessed, and implemented.

There are currently twenty-four AOCs (some of which include sub-areas) at the BNL site to be addressed through the IAG. The AOC's consist of both active facilities (STP, HWMF, ...) and inactive facilities (former landfills, cesspools, radioactive storage tanks, ...). The AOCs are currently being grouped and prioritized into more workable "operable units" and removal actions.

As a result of a near-term work schedule agreed to by DOE, EPA, and DEC during 1990, the preparation of RI/FS project plans at one operable unit (CSF, Building 650 sump, leaking sewer lines) has been initiated, as well as planning activities at three removal actions (decontamination and decommissioning of three large above-ground radioactive waste storage tanks; sampling and removal of various underground storage tanks; and sampling, and removal if necessary, of various industrial cesspools). During 1990, the following reports have also been prepared and submitted to EPA and DEC for their review; Solid Waste Management Unit Classification Report, Historical Site Review Work Plan, Underground Storage Tank Sampling Results, and Conceptual Treatment Plan, and Cesspool Sampling and Analysis Plan. 


\subsection{Superfund Amendments and Reauthorization Act (SARA) of 1986}

The SARA regulations require that BNL compile and submit Tier I reports to the New York State Emergency Response Commissioner, the Suffolk County Local Emergency Response Committee and the responding fire organization. For BNL, the responding fire organization is the S\&EP Fire and Rescue Group. For CY 1990, BNL submitted to these groups the Tier I report. This report contained the maximum and average daily amounts for all chemicals, determined from inventory and purchasing records, which fall into the following categories: physical hazards, classified by type as fire, sudden release of pressure or reactivity, and health hazards, classified by type as immediate (acute) and delayed (chronic). The quantities reported are listed as follows:

Gazard Type

Fire

Sudden Rolease of Pressure

Reactivity

Imnediate (acute)

Delayed (chrontc)

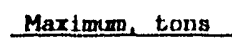

5,000 to 25,000

5,000 to 25,000

50 to 500

5,000 to 25,000

5,000 to 25,000
Average, tons

50 to 500

50 to 500

5 to 50

50 to 500

50 to 500
Lonation

Butldings $630, \quad 326$ and 610

Butldings 158 and 901

Butldings $158, \quad 555$ and 197

Buildings 158, 555, 197 and 610

Butldings 158, 610 , 197 and 555

Brookhaven National Laboratory is not required under the SARA regulations to submit a Tier II report that provides detail regarding the chemicals and quantities within each hazard type unless requested by an outside agency. In 1991. New York State requested that this report be submitted. Brookhaven National Laboratory complied with this request.

\subsection{National Environmental Policy Act (NEPA)}

In 1990, the Laboratory showed its strong commitment to full compliance with NEPA and DOE Order $5440.1 D^{49}$ through the hire of a dedicated NEPA compliance officer. The BNL NEPA Policy continued to take shape with draft protocols addressing construction, operation, capital improvement, and research projects issued in June and October. To further promote NEPA compliance, Dames and Moore was contracted to prepare an Occupational Health and Safety Guide which would include procedures for NEPA compliance. The first draft of this guide was reviewed in October.

Environmental evaluations were completed for 166 projects in accordance with the NEPA protocol. Of these, 44 were considered minor actions requiring no additional documentation and 122 had Environmental Evaluation Forms completed for submission to DOE. These forms are the basis used to determine if additional documentation is required or if a project falls under one of the Categorical Exclusions to NEPA approved for the DOE. The second level of documentation, a Memorandum-To-File (MTF), was completed and approved for additions to BNL's 
Central Shops and Computing and Communications buildings, and the installation of a new boiler at the CSF. Environmental Assessments (EAs) were prepared for the proposed Science Education Center and Child Development Facility buildings. After review by DOE-HQ, it was determined that the appropriate level of documentation for these projects should have been MTFs. An MTF was subsequently prepared and approved for each project. Draft EAs were also prepared for the construction of a Laser Laboratory in Building $535 \mathrm{~B}$ and the construction and operation of the Relativistic Heavy Ion Collider (RHIC).

Potential cultural resource impacts were coordinated through the New York State Historic Preservation Officer (SHPO). Representatives of the SHPO toured

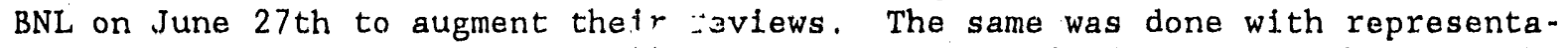
tives of the NYSDEC on August 14 th for projects with the potential to impact fresh water wetlands within their jurisdiction.

\subsubsection{Environmental Assessment for the RHIC}

Dames and Moore completed a draft EA for the RHIC project in March, 1990. After internal modifications, this document was formally transmitted to DOE for comment in June, 1990. Revisions to the document. were completed in August and December, 1990. It is anticipated that the document will be released for public review in 1991.

\subsection{Federal Insecticide, Fungicide, and Rodenticide Act}

Brookhaven National Laboratory has two programs where insecticides and pesticides are used. As per the regulatory requirements, both users, the Biology Department and Plant Engineering Division (Grounds Section) maintain a log of applications made and a $\log$ on the inventory at each facility. In addition, key personnel axe trained and the training updated annually on the handling and application of these chemicals. Formal reporting is not required, however, the log books are available for inspection and verification to auditing agencies.

\subsection{Endangered Species Act}

Brookhaven National Laboratory has received notification from the U.S. Fish and Wild Life Service and the NYSDEC that there are no endangered species resident on the site.

\subsection{National Historic Preservation Act}

The BNL site contains two standing structures, the Graphite Reactor Building (B1dg. 701) and the 0ld Cyclotron enclosure (B1dg. 902), along with the World War I era trencher that are of interest to the NYS Office of Parks, Recreation, and Historic Preservation. Brookhaven National Laboratory must consult with this agency only on projects that have any potential impact on these resources. In all other projects, there is no effect upon cultural resources that would require inclusion in the National Register of Historic Places. Implementation of the NEPA process ensures compliance with this Act. 


\subsection{Flood Plain Management}

There was no construction in flood plain areas during CY 1.990.

\subsection{Protection of Wetlands}

In August of 1990, a representative from NYSDEC conducted a preapplication consultation at the BNL site. This visit was made in anticipation of BNL applications to construct environmental monitoring enclosures and install flow monitoring devices as part of an S\&EP environmental program upgrade project plus an application to improve the RHIC ring road. During the visit, wetland areas were identified.

\subsection{Compliance Issues During First and Second Quarter of 1991}

This section provides a brief overview of the major compliance issues encountered at BNL during the first two quarters of CY 1991. These issues will be discussed in detail in the Site Environmental Report for CY 1991.

\subsection{7 .1 SPDES Compliance Issues}

During the first two quarters of 1991, there were two instances of noncompliance with the existing SPDES permit. In March, a split sample collected from Location EA by the EPA was analyzed by BNL for volatile organics. The compound TCA was detected in excess of the NYS DWS. Organic compounds are not on the list of allowable discharges to the sanitary system. However in a prior sample, NYSDEC had identified TCA in the effluent and was proposing to include the compound in the revised SPDES permit. In April, BNL initiated a daily sampling program to determine the range of detectable organic concentrations that were present in STP influent, effluent, and in surface water prior to leaving the BNL site. This investigation identified the presence of several facilities that discharged organic compounds, noticeably TCA, to the sanitary sewer system. Review of these operations identified various alternatives to discharge of this material into the environment. Consequently, TCA concentrations are typically below the NYS DWS. Other compounds detected in this investigation were methylene chloride, toluene, and acetone. Although present in STP influent, these compounds were rarely detectable in liquid discharges to the Peconic River and never detected in the surface water leaving the site. This incident is being reported in an Unusual Occurrence Report.

The second non-compliance occurred with the discharge of lubricating oil from an elevator to Recharge Basin HT (Outfall 006). A piston elevator located in Building 930 developed a leak in a seal that permitted the discharge of about 1 to 2 gallons of lubricating oil. The oil was removed from the water by adsorption on to adsorbent pads. The elevator seal was repaired prior to continued use of the elevator. This incident is reported in a Unusual Occurrence Report. 


\subsubsection{NESHAPs Compliance for Radioactive Airborne Emissions}

Experiments, construction of new facilities, and modification to airborne effluent sources that have the potential to generate an NESHAPs evaluation. No potential sources required formal application to EPA Region II.

\subsubsection{Compliance with NYS Air Laws}

Efforts continued during the first two quarters of 1991 to bring air emission sources into compliance with NYS Air Laws. Applications for COs for three existing sources were submitted to NYSDEC in January, 1991. A request to cancel an existing $C O$ for a source at Building 452, which is no longer in service, was submitted to NYSDEC in February, 1991, Renewals for four COs were also submitted to NYSDEC in February, 1991. The NYSDEC issued PGs for two new sources at Building 197 in March, 1991. A request was submitted to NYSDEC for a determination of PSD nonapplicability for the proposed CSF Boiler No. 7 in April, 1991. Preparation of the PC for proposed CSF Boiler No. 7 was also initiated during the second quarter of 1991. Efforts continued during the first two quarters of 1991 for the installation, debugging, and testing of the continuous emission monitors required at CSF Boiler No. 6.

\subsubsection{SDWA Compliance Issues with SDWA}

The SCDHS reviewed the report describing the testing of the BNL WTP for VOC removal. After consultation with individuals at the NYSDOH, SCDHS found it to be a' satisfactory. demonstration that the existing aeration stage of the WTP constitutes adequate treatment such that Potable Well No. 4 could be returned to service. This approval is subject to the following conditions: (1) that the levels of synthetic organic compounds (SOCs) do not change substantially from the ranges encountered thus far; (2) that SOCs are not encountered in other wells feeding the WTP; (3) that quarterly SOC analytical samples be taken from the treated wate $i$ from the WTP; and (4) that all other routine monitoring of the wells continue at the current frequencies required. Samples will continue to be collected at Potable Well No. 4 in order to evaluate the VOC removal efficiency and to isolate the well-source if a significant increase in SOCs is encountered. Based on Lhis approval, Potable Well No. 4 was returned to service in February, 1991.

\subsubsection{TSCA Compliance Issues}

Departments and Divisions were requested to review and update their inventory of equipment containing PCBs in May, 1991. This information was provided to the S\&EP Division and incorporated into the PCB inventory database. The BNL annual PCB report for CY 1990 was prepared in accordance with Section 761.180 of TSCA during the second quarter of 1991.

\subsubsection{RCRA Compliance Issues}

In response to both Tiger Team findings ${ }^{32}$ and observations of the EPA multi-media inspection, the HWMF is undergoing two immediate facility upgrades. First, outdoor modular storage units with automatic dry chemical fire suppression systems were installed and more have been ordered. Second, additional fire 
protection capability is being addressed through the installation of a water storage tank near Bullding 483, the Drum Storage Facility. In addition to upgrades to existing facilities, the HWM group recelved revised conceptual design reports for new facilities that will satisfy all code requirements. These reports were forwarded to DOE-CH and EM with EM staff performing an Independent Cost Review in February, 1990.

\subsubsection{SARA Compliance Issues}

In 1991, New York State requested that a SARA Tier II report be provided for CY 1990. This report was prepared and submitted to NYS in August of 1991.

\subsubsection{NEPA Compliance}

Review of projects, research, and construction activities continued in an effort to comply with the provisions of DOE Order 5440.1D. The major accomplishment during this period was the completion of the RHIC Environmental Assessment and receipt of concurrence from DOE Head Quarters. The docurnent is now ready for transmittal to other interested regulatory parties.

\subsection{7 .9 Status of IAG Activities}

In accordance with the proposed IAG milestones, a Work Plan for historical site review was submitted to EPA and NYSDEC for review in October, 1990, with the Plan being approved in January, 1991. A draft Site Baseline Report, which presents past monitoring data and other background information for the twentyfour AOCs at BNL, and a draft soli sampling and analysis plan for the "D" lowlevel radioactive waste storage tank removal action were prepared and submitted to EPA and NYSDEC for review in February, 1991. A site-wide Community Relations Plan, which describes the community relation activities to be conducted during the environmental. restoration work at BNL, was prepared and submitted to EPA and NYSDEC for review in April. The first oU that is being addressed under the IAG is OU 4, the Central Steam Facility, and Building 650 Sump areas. A draft RI/FS work plan for this area was prepared and submitted to EPA and NYSDEC for their review in April. Following regulatory approval of this plan, remedial investigation field activities are expected to commence in the spring of 1992 .

\subsubsection{EPA Mult1-media Inspection}

In order. to initiate more comprehensive and integrated environmental protection and compliance activities, EPA Region II in 1991 began sending inspection teams to major facilities that have the potential to impact a variety of environmental media. A team consisting of approximately 15 inspectors with expertise in CAA, SDWA, NPDES, SPCC RCRA, TSCA, USTs, and NESHAPs regulatory programs performed an inspection of BNL during the week of March 4, 1991. The inspection consisted of interviews with BNL personnel, inspection of facilities, review of data reports and compliance documentation, and periodic sampling to confirm effluent releases. A close-out meeting was held at the conclusion of the inspection to discuss significant findings. 
Subsequent to the close-out meeting, BNL has recelved written comments from EPA regarding the findings and recommendations of their inspectors. In late March, 1991, correspondence was recelved concerning compliance with the SDWA stating that the BNL potable water system is currently in compliance with all SDWA requirements. The inspectors did make several recommendations which BNL is evaluating. In Apr11, 1991, comments were received regarding Class $V$ wells that are regulated under the Underground Infection Control section of the SDWA requesting additional information. This information was supplied to EPA. In July, 1991, DOE/BHO and BNL received a response to the information sent. Brookhaven National Laboratory and DOE-BHO are evaluating and preparing a response to EPA.

The EPA issued a Deficlency Notice to BNL for issues regarding compliance with NPDES in Apri1, 1991. The AOCs included measurement of Total suspended Solids, Biochemical Oxygen Demand, quality control documentation regarding the recording of temperature on the incubator and refrigerator used for $\mathrm{BOD}_{5}$, and parameters such as $\mathrm{pH}$, dissolved oxygen, moisture content of ovens, and use of chemicals that had exceeded shelf expiration dates and issues regarding the verification of procedures at the contractor laboratory where analyses are performed for fecal and total coliform. Brookhaven National Laboratory responded to this notice in May with corrective actions on al1 issues except for procedural changes at the contractor laboratory. This last issue was resolved in June.

The EPA requested additional information regarding BNL implementation and compliance with the $C A$ in June 1991. Information regarding combustion units at the CSF was compiled and transmitted to EPA in July. Information relating "coating line" at Building 458 was transmitted in August of this year. Further correspondence is expected upon completion of the data review by EPA.

In early July, EPA issued NOVs to BNL on RCRA and TSCA issues. The EPA identifled eight RCRA and ten TSCA violations. The BNL technical staff and legal counsel plus DOE-BHO are reviewing the NOVs and are preparing a response that is scheduled for submission to EPA in August, 1991. 


\section{APPENDIX A}

\section{A. 1 Glossary of Terms}

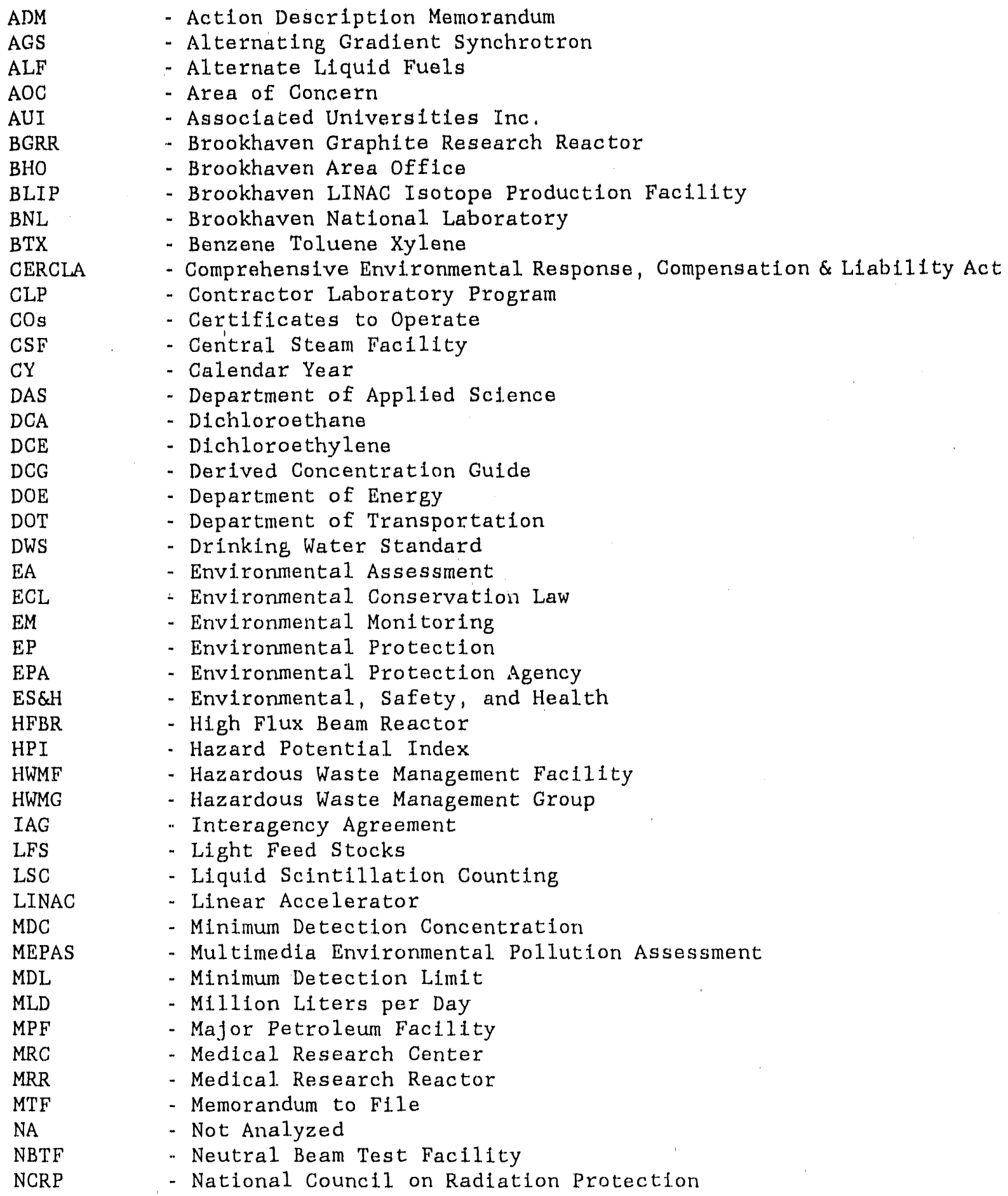




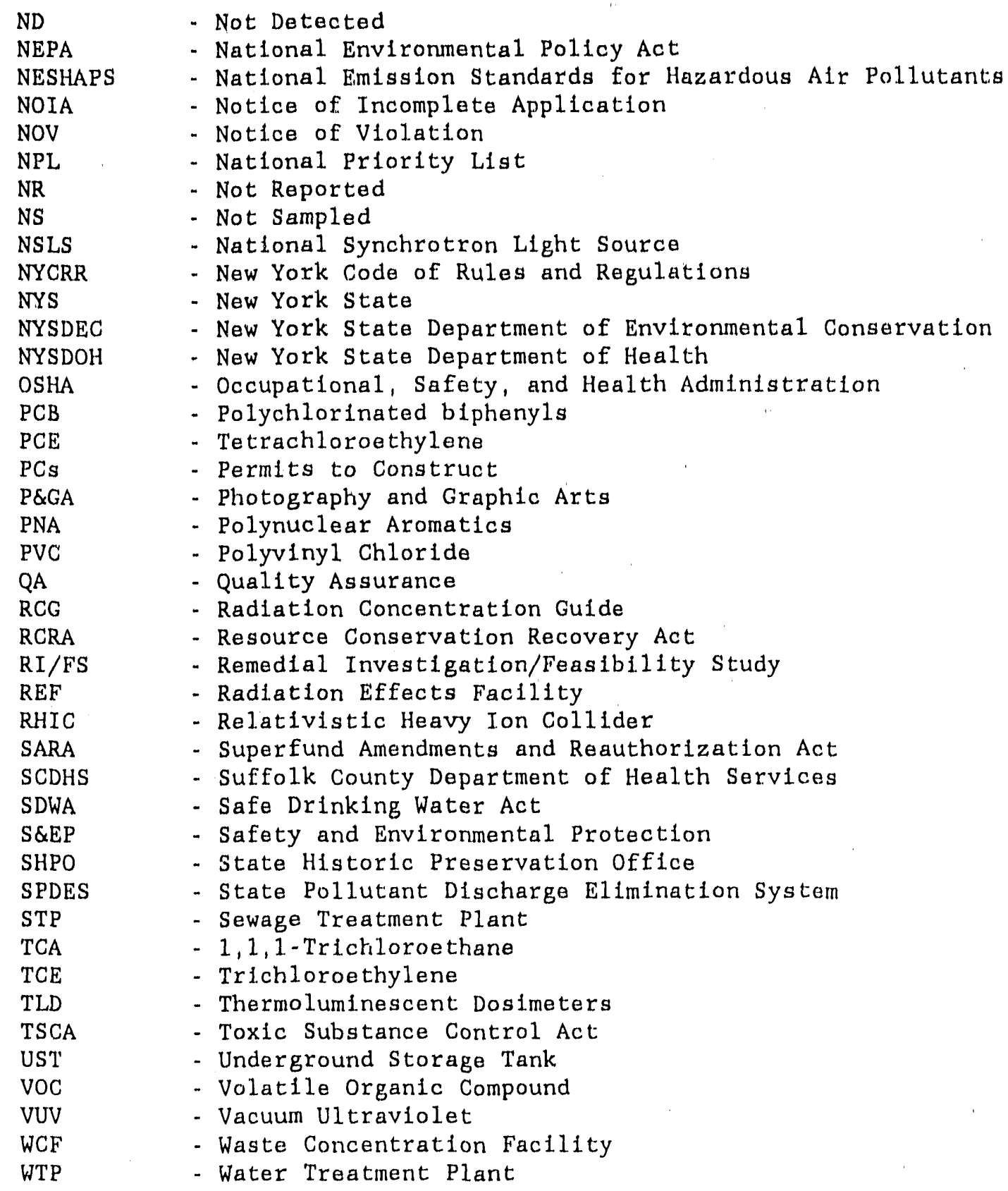




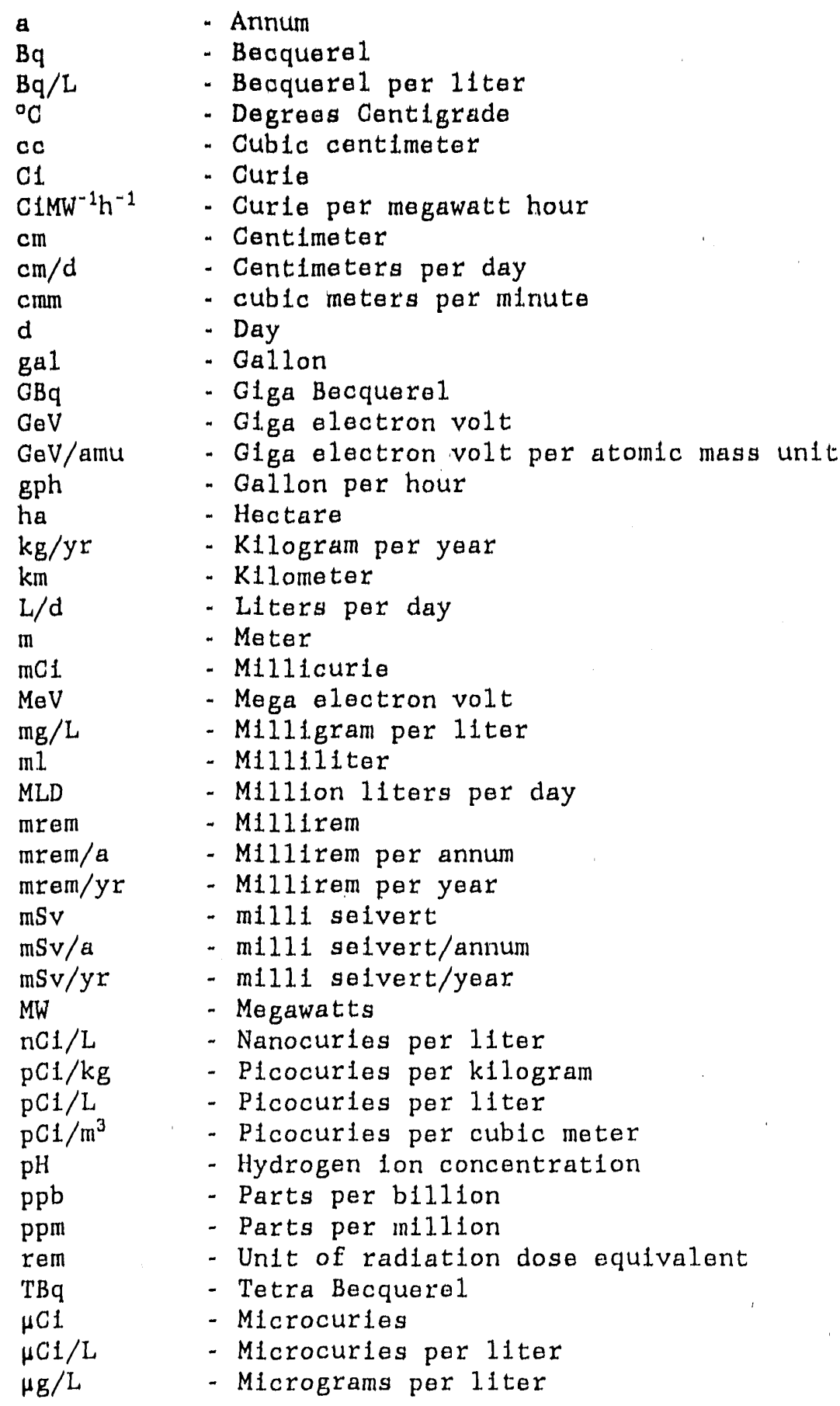




\title{
APPENDIX B
}

\section{METHODOLOGIES}

\section{Methodology for Dose-Equivalent Calculations - Atmospharic Release Pathway}

Disperafon was calculated for release elevations as listad in Appondix $D_{1}$ Table 4, at each of the 16 directional sectors, and for 6 distance increments (site boundary, $1,6-16 \mathrm{~km}, 16-32 \mathrm{~km}, 32-48 \mathrm{~km}, 48-64 \mathrm{~km}$, and $64-80 \mathrm{~km}$ ) from the center of the site using CAP88. The 1990 site meteorology as measured at 10 and 100 meter elevations was used to calculate the annual avarage dispersion for the midpoint of a given sector and distance. The radionuclide specific release rates (C1/yr) from the HFBR stack, the Chemistry Bullding roof val, the Van de Graaff roof vent, the BLIP stack, and the Hazardous Waste Managemint Inclnerator stack were used to determine the annual emission rate for each radionuclide. The site boundary and collective were obtained from the CAP8 8 computer code printout. The CAP88 calculates the total dose due to contributions from the submersion, ingestion, shoreline, and recreational pathways as a result of an atmospheric release. In 1990, two percent of the tritfum atmospheric relase from the 100 m stack was added to the 10 meter tritfum source term in an effort to account for down-draft at the 100 meter stack.

2. Method for Trftiun Dose-Equivalent Calculations - Potable Water Ingestion Pathway

The method used to calculate the maximum individual comitted effective dose equivalent and the oollective dose equivalent are present along with the basic assumptions used in the calculation. For the maximum individual, the highest annual average tritium concentration, as measured from a single potable well was used to calculate the total quantity of tritlum ingested via the drinking water pathway. For the collective dose equivalent calculation, the annual average tritium concentration was obtained by averaging all positive results from potable wells which were in the demographic region adjacent to the Laboratory. The annual intake of tritium via the drinking water pathway was calculated from the following equation:

$$
A I=1 \times 10^{-6} \mathrm{C} \cdot \mathrm{IR} \cdot \mathrm{T}
$$

\author{
where: AI $=$ Activity Intake, $\mu \mathrm{CI}$ \\ $\mathrm{C}=$ annual average water concentration, $\mathrm{pC} 1 / \mathrm{L}$ \\ $I R$ - Ingestion Rate (2) L/d \\ $T=T$ ime, $365 \mathrm{~d}$
}


The comitted effective dose equivalent was calculated from the following equation:

$$
H-A I \cdot D C F+P
$$

where: H - committed effective dose equivalent, rem

AI - Activity Intake, $\mu C 1$

DCF - Dose Conversion Factor, Rem $/ \mu \mathrm{Cl}(6.3 \mathrm{E}-5 \mathrm{rem} / \mu \mathrm{Ci})$

P - Population at risk

To determine the maximum individual dose, the population parameter was set to unity. For the collective dose calculation, the population at risk in this area was assumed to be approximately 500 .

\section{Methodology for Dose-Equivalent Calculations - Fish Ingestion Pathway}

In order to estimate the collective dose equivalent from the fish consumption pathway, the following procedure was utilized:

a. Radionuclide data for fish samples were all converted to $\mathrm{pCl} / \mathrm{kg}$ wet weight, as this is the form in which the fish is used.

b. The average fish consumption for an individual who does recreational fishing in the Peconic River was based on a study done by the NYSDEC which suggests that the consumption rate is $7 \mathrm{~kg} / \mathrm{yr}$. [55]

c. Committed Dose Equivalent Tables [56] were used to get the 50 year Committed Dose Equivalent Factor - rem/ $\mu \mathrm{Ci}$ intake.

The factors for the ingestion pathway for the radionuclides identified were:

$$
\begin{array}{r}
{ }^{3} \mathrm{H}: \quad 6.3 \mathrm{E}-05 \mathrm{rem} / \mu \mathrm{Cl} \text { intake } \\
{ }^{90} \mathrm{Sr}: \quad 1.3 \mathrm{E}-01 \mathrm{rem} / \mu \mathrm{Cl} \text { intake } \\
{ }^{137} \mathrm{Cs}: \quad 5.0 \mathrm{E}-02 \mathrm{rem} / \mu \mathrm{Cl} \text { intake }
\end{array}
$$

d. Calculation:

Intake ( $7 \mathrm{~kg} / \mathrm{yr}$ ) x Activity in flesh $\mu \mathrm{Ci} / \mathrm{kg}$

$\mathrm{x}$ Factor rem $/ \mu \mathrm{Cl}$ intake = rem

e. Because there is a cesium-137 background as determined by the control location data, this background was subtracted from all data prior to use for dosimetric purposes. 


\section{Data Processing}

Analytical results of the environmental and effluent monitoring programs are reported in the tables of Appendix $D$. The data presented in these tables were generated as described below.

First, gross alpha, beta, and tritium results are reported as the net measured quantity. When only one sample was analyzed, results could be positive, zero, or negative. When the average concentration is reported, the average was computed by averaging the volume-weighted measured quantity. Because measured quantities were used throughout the report for these parameters, the reader should examine Appendix $C$ to determine the typical analytical sensitivity for a particular parameter prior to deciding the importance of a result. Data which are less than the MDC of the aralytical technique should not be considered as positive results. Only data which exceed the MDC were used as positive results.

Second, gamma spectroscopy, strontium-90, and cheinical analytical results were not converted to the new data presentation format; measured concentrations that were less than $C_{-}$equal to the MDC, while reported, were not used to compute average concentration levsls. All MDC values were evaluated as if the results were zero. This explains occasional instances where the MDC is several times larger than the calculated annual average concentration.

Finally, if an analysis was performed and the result was less than the MDC of the system, the concentration was generally reported as not detected (ND). Appendix C presents typical minimum detectable concentrations for the analyses performed on environmental and effluent samples. 
The following is a list of typical Minimum Detectable Limits and Concentrations for the various analyses performed on environmental and effluent samples.

\begin{tabular}{lcccc}
\hline Nuclide & Matrix & $\begin{array}{c}\text { Aliquot } \\
(\mathrm{m} 1)\end{array}$ & $\begin{array}{c}\text { MDC } \\
(\mu \mathrm{Ci} / \mathrm{ml})\end{array}$ & $\begin{array}{c}\text { MDL } \\
(\mu \mathrm{Ci})\end{array}$ \\
\hline Gross alpha & water & 1 & $2 \mathrm{E}-7$ & $3 \mathrm{E}-7$ \\
& & 100 & $2 \mathrm{E}-9$ & \\
Gross beta & water & 500 & $5 \mathrm{E}-10$ & $6 \mathrm{E}-7$ \\
& & 1 & $6 \mathrm{E}-7$ & \\
\multirow{2}{*}{ Tritium } & 100 & $6 \mathrm{E}-9$ & \\
& water & 500 & $1 \mathrm{E}-9$ & $1.3 \mathrm{E}-6$ \\
& & 1 & $1.3 \mathrm{E}-6$ &
\end{tabular}

\begin{tabular}{lllll}
\hline Nuclide & $\begin{array}{l}300 \mathrm{~g} \\
\mathrm{MDL} \\
\mu \mathrm{Ci} / \mathrm{g}\end{array}$ & $\begin{array}{l}300 \mathrm{ml} \\
\mathrm{MDL} \\
\mu \mathrm{Ci} / \mathrm{m} 1\end{array}$ & $\begin{array}{l}12000 \mathrm{ml} \\
\mathrm{MDL} \\
\mu \mathrm{Ci} / \mathrm{ml}\end{array}$ & $\begin{array}{l}\text { Charcoal } \\
\mathrm{MDC} \\
\mu \mathrm{Ci}\end{array}$ \\
\hline${ }^{7 \mathrm{Be}}$ & $7.4 \mathrm{E}-8$ & $9.8 \mathrm{E}-8$ & $1.6 \mathrm{E}-9$ & $9.3 \mathrm{E}-6$ \\
${ }^{22} \mathrm{Na}$ & $9.4 \mathrm{E}-9$ & $1.2 \mathrm{E}-8$ & $2.0 \mathrm{E}-10$ & $1.4 \mathrm{E}-6$ \\
${ }^{40} \mathrm{~K}$ & $1.8 \mathrm{E}-7$ & $2.3 \mathrm{E}-7$ & $3.9 \mathrm{E}-9$ & $2.7 \mathrm{E}-5$ \\
${ }^{48} \mathrm{Sc}$ & $1.1 \mathrm{E}-8$ & $1.4 \mathrm{E}-8$ & $2.3 \mathrm{E}-10$ & $1.6 \mathrm{E}-6$ \\
${ }^{51} \mathrm{Cr}$ & $7.6 \mathrm{E}-8$ & $1.0 \mathrm{E}-7$ & $1.6 \mathrm{E}-9$ & $9.0 \mathrm{E}-6$ \\
${ }^{54} \mathrm{Mn}$ & $8.4 \mathrm{E}-9$ & $1.1 \mathrm{E}-8$ & $1.8 \mathrm{E}-10$ & $1.1 \mathrm{E}-6$ \\
${ }^{56} \mathrm{Mn}$ & $2.2 \mathrm{E}-7$ & $2.8 \mathrm{E}-7$ & $4.7 \mathrm{E}-9$ & $3.1 \mathrm{E}-5$ \\
${ }^{57} \mathrm{Co}$ & $7.2 \mathrm{E}-9$ & $9.2 \mathrm{E}-9$ & $1.4 \mathrm{E}-10$ & $7.5 \mathrm{E}-7$ \\
${ }^{58} \mathrm{Co}$ & $8.3 \mathrm{E}-9$ & $1.1 \mathrm{E}-8$ & $1.8 \mathrm{E}-10$ & $1.1 \mathrm{E}-6$ \\
${ }^{60} \mathrm{Co}$ & $1.1 \mathrm{E}-8$ & $1.4 \mathrm{E}-8$ & $2.3 \mathrm{E}-10$ & $1.5 \mathrm{E}-6$ \\
${ }^{65} \mathrm{Zn}$ & $2.1 \mathrm{E}-8$ & $2.2 \mathrm{E}-8$ & $4.5 \mathrm{E}-10$ & $3.0 \mathrm{E}-6$ \\
${ }^{134} \mathrm{Cs}$ & $1.1 \mathrm{E}-8$ & $1.4 \mathrm{E}-8$ & $2.2 \mathrm{E}-10$ & $1.4 \mathrm{E}-6$ \\
${ }^{137} \mathrm{Cs}$ & $9.5 \mathrm{E}-9$ & $1.2 \mathrm{E}-8$ & $2.0 \mathrm{E}-10$ & $1.3 \mathrm{E}-6$ \\
${ }^{226} \mathrm{Ra}$ & $2.6 \mathrm{E}-8$ & $3.0 \mathrm{E}-8$ & $5.0 \mathrm{E}-10$ & $2.9 \mathrm{E}-6$ \\
${ }^{228} \mathrm{Th}$ & $2.1 \mathrm{E}-8$ & $2.7 \mathrm{E}-8$ & $4.3 \mathrm{E}-10$ & $2.4 \mathrm{E}-6$ \\
${ }^{82} \mathrm{Br}$ & $1.2 \mathrm{E}-8$ & $1.6 \mathrm{E}-8$ & $2.6 \mathrm{E}-10$ & $1.6 \mathrm{E}-6$ \\
${ }^{113} \mathrm{Sn}$ & $1.2 \mathrm{E}-8$ & $1.6 \mathrm{E}-8$ & $2.6 \mathrm{E}-10$ & $1.4 \mathrm{E}-6$ \\
${ }^{124} \mathrm{I}$ & $1.3 \mathrm{E}-8$ & $1.7 \mathrm{E}-8$ & $2.7 \mathrm{E}-10$ & $1.7 \mathrm{E}-6$ \\
${ }^{126} \mathrm{I}$ & $2.3 \mathrm{E}-8$ & $3.3 \mathrm{E}-8$ & $5.2 \mathrm{E}-10$ & $2.8 \mathrm{E}-6$ \\
${ }^{131} \mathrm{I}$ & $9.4 \mathrm{E}-9$ & $1.3 \mathrm{E}-8$ & $2.1 \mathrm{E}-10$ & $1.1 \mathrm{E}-6$ \\
${ }^{133} \mathrm{I}$ & $1.2 \mathrm{E}-8$ & $1.6 \mathrm{E}-8$ & $2.6 \mathrm{E}-10$ & $1.6 \mathrm{E}-6$ \\
${ }^{123} \mathrm{Xe}$ & $6.6 \mathrm{E}-7$ & $8.6 \mathrm{E}-7$ & $1.3 \mathrm{E}-8$ & $7.3 \mathrm{E}-5$ \\
${ }^{127} \mathrm{Xe}$ & $1.0 \mathrm{E}-8$ & $1.3 \mathrm{E}-8$ & $1.0 \mathrm{E}-10$ & $1.2 \mathrm{E}-6$
\end{tabular}




\begin{tabular}{ll}
\hline $\mathrm{Ag}$ & 0.025 \\
$\mathrm{Cd}$ & 0.0005 \\
$\mathrm{Cr}$ & 0.005 \\
$\mathrm{Cu}$ & 0.05 \\
$\mathrm{Fe}$ & 0.075 \\
$\mathrm{Hg}$ & 0.0002 \\
$\mathrm{Mn}$ & 0.05 \\
$\mathrm{Na}$ & 1.0 \\
$\mathrm{~Pb}$ & 0.005 \\
$\mathrm{Zn}$ & 0.02 \\
$\mathrm{Ammonia}-\mathrm{N}$ & 0.02 \\
$\mathrm{Nitrite}-\mathrm{N}$ & 0.01 \\
$\mathrm{Nitrate}-\mathrm{N}$ & 1.5 \\
$\mathrm{Specific}$ Conductance & $10 \mathrm{umh} / \mathrm{cm}$ \\
Chlorides & 6.0 \\
Sulfates & 6.0 \\
1,1,1-trichloroethane & 0.002 \\
trichloroethylene & 0.002 \\
tetrachloroethylene & 0.002 \\
chloroform & 0.003 \\
chlorodibromomethane & 0.002 \\
bromodichloromethane & 0.002 \\
bromoform & 0.002 \\
benzene & 0.002 \\
toluene & 0.002 \\
xylene & 0.002
\end{tabular}




\section{APPENDIX C \\ INSTRUMENTATION AND ANALYTICAL METHODS}

The analytical laboratory of S\&EP Division is divided into 1) radiological, and 2) non-radiological sections to facilitate analysis of specific parameters in each category. The following analytes are analyzed in each category.

1) Radiological: Gross alpha, gross beta, gamma, tritium and $\mathrm{sr}^{90}$.

2) Non-radiological: Purgeable aromatics, Purgeable halocarbons, PCBs, anions and metals.

A brief description of methods and instrumentation for each category is given below. Only validated and regulatory referenced methods are used during the analysis. All samples, are collected and preserved by trained technicians according to appropriate referenced methods. Well qualified and trained analysts are involved in performing different analysis. The analytical laboratory is certified by $N Y$ State Department of Health (NYDOH) for all non-radiological parameters, except for PCBs. The radiological laboratory participates in:

\section{1a) Gross Alpha and Gross Beta Analysis - Water Matrix:}

Water samples are collected in one liter polyethylene containers. No preservatives are added prior to sample collection. If the samples are effluent or surface stream samples from locations DA, EA, HM, or HQ or Building 535B daily process samples then $100 \mathrm{ml}$ are extracted for analysis. Ground water samples are typically analyzed using a $500 \mathrm{ml}$ aliquot. Due to high iron content, $100 \mathrm{ml}$ aliquots of ground water samples from the landfill areas may be used in this analysis. The aliquot is evaporated to near dryness in a glass beaker. The beaker is rinsed to remove the solids and the combined solids and rinsate are transferred to a $5 \mathrm{~cm}$ diameter planchet. The planchettes are evaporated to dryness, allowed to cool and then are counted in a gas flow proportional counter for 50 minutes. Samples are normally processed in batch mode. The first sample of each batch is a background that is subtracted from the raw data prior to computation of net concentration. System performance is checked daily with an americium-241 and chlorine-36 source.

1b) Gross Alpha and Gross Beta Analysis - Air Particulate Matrix:

Air particulate samples are collected on $50 \mathrm{~mm}$ filters at a nominal flow rate of 15 liters per minute. At the end of the collection period, particulate filters are returned to the analytical laboratory for assay. Filter papers are counted twice in a gas flow proportional counter for 50 minutes. The first count occurs immediately upon receipt in the analytical laboratory. This count is used to screen the samples for unusual levels of air particulate activity. The filters are then recounted approximately one week later. The week delay permits decay of the short-lived radon/thoron daughters. The second analysis is used for environmental assessments. The first sample of each batch is a an empty chamber (no filter paper) background that is subtracted from the raw data prior to computation of net concentration. System performance is checked daily with an americium-241 and chlorine-36 source. 
Water samples are collected in one liter polyethylene containers. No preservatives are added prior to sample collection. If the samples are effluent or surface stream samples from locations DA, EA, HM, or HQ or building 535B daily process samples then $1 \mathrm{ml}$ is extracted for analysis. Ground water and potable water samples are typically analyzed using a $7 \mathrm{~m} 1$ aliquot. Liquid scintillation cocktail is then added to the sample aliquot so that the final volume in the liquid scintillation counting vial is $15 \mathrm{ml}$. Samples are then counted in a low background liquid scintillation counter for 100 minutes. Samples are normally processed in batch mode. The first sample of each batch is a background that is subtracted from the raw data prior to computation of net concentration. The second sample in each batch is a standard that is used to compute system performance and efficiency. Each sample is also checked for quenching. Corrections for background, quenching and current system efficiency for the sample matrix and size are factored into the final net concentrations for each sample.

\section{Tritium Analysis - Air Matrix:}

Ambient and facility tritium air concentrations are measured by drawing the air at a rate of approximately $200 \mathrm{cc} / \mathrm{m}$ through a desiccant. At the end of each collection period, typically one week, the desiccant is brought to the analytical laboratory for processing. The desiccant is dried in a glass manifold system. Effluent samples have dedicated glassware as do environmental samples. The off gas containing moisture from the sampled air is collected by means of a liquid nitrogen trap. This water is then assayed for tritium content. A $7 \mathrm{ml}$ aliquot is used for analysis. Liquid scintillation cocktail is then added to the sample aliquot so that the final volume in the liquid scintillation counting vial is 15 ml. Samples are then counted in a low background liquid scintillation counter for 100 minutes. Samples are normally processed in batch mode. The first sample of each batch is a background that is subtracted from the raw data prior to computation of net concentration. The second sample in each batch is a standard that is used to compute system performance and efficiency. Each sample is also checked for quenching. Corrections for background, water recovery, air sample volume, quenching and current system efficiency for the sample matrix and size are factored into the final net concentrations for each sample.

1e) Strontium-90 Analysis:

Strontium-90 analyses are currently performed on water, soll, and aquatic biota samples. Typically, at least four liters of liquid and one kilogram of solid sample is shipped to the contractor laboratory. The analysis proceeds by using the HASL- 300 procedure which utilizes wet chemistry techniques to isolate strontium-90 from the sample. Samples are counted twice to verify strontium-90 and yttrium-90 ingrowth. Chemical recoveries are determined by a combination of gravimetric and strontium-85 standard addition techniques. Samples are typically process in a batch. Backgrounds and system performance are verified with each batch. Chemical recoveries for both strontium-90 and yttrium-90 are determined for each sample. 
Surface, potable and ground water surveillance samples are typically 12 liter samples that are placed in polyethylene bottles without preservatives. Samples are then passed through a mixed bed ion exchange column at a rate of 20 $\mathrm{cc} / \mathrm{m}$ until all 12 liters have passed through the column. The column is then removed, placed in a teflon coated aluminum can and counted for 50,000 seconds. Where effluent sampling is performed in a flow proportional manner, 10 cc aliquots are passed through the mixed bed column on an as needed basis. Typically samples sizes for this type of sample tend to approach the 50 to 100 1iter size. Air particulate filter papers are counted directly on the detector for 10,000 seconds. Charcoal filter canisters are also counted directly on the detector with a count time or 50,000 seconds. Soil, vegetation and aquatic biota are all processed following collection. Typically, $50 \mathrm{~g}, 100 \mathrm{~g}$, or $300 \mathrm{~g}$ aliquots are taken, placed in a teflon lined canister and directly counted. For gamma spectroscopy analyses, backgrounds are collected once per week and system performance is verified daily. Analytical results reflect net activity that has been corrected for background and system response of the detection medium

\section{2a) Purgeable aromatics and purgeable halocarbons:}

Water samples are collected in $40 \mathrm{ml}$ glass vials with removable teflonlined caps without any headspace and stored at $4^{\circ} \mathrm{C}$ and analyzed within 14 days.

Ten (10) purgeable compounds (benzene, toluene, ethyl benzene, total xylenes, chloroform, 1,1-dichloroethane, 1,1-dichloroethylene, tetrachloroethylene, 1,1,1-trichloroethane, and trichloroethylene) are analyzed under this category following EPA method 624 protocols using gas chromatography/mass spectrometry (GCMS). These ten compounds were chosen as the target compounds since they are known or suspected to be present in the monitoring wells based on the DOE survey of the sight in $1988^{57}$ and a comprehensive analysis of 51 new monitoring wells using EPA's Contract Laboratory Program (CLP) ${ }^{58,59}$ procedures in 1989. There are currently two Hewlett-Packard GCMS instruments. One instrument is exclusively used for the analysis of purgeable compounds and the other for screening extractables and other extraneous compounds in non-routine samples. Since ground water under BNL is classified as a sole source aquifer, the detection limits reported for the compounds are close to drinking water standards.

The method involves purging a $25 \mathrm{ml}$ aliquot of the sample with ultra pure helium in a specially designed sparger using Purge and Trap technique. Each sample is spiked with known concentration of internal standards and surrogates before purging to facilitate identification, quantitation and determination of the extraction efficiency of analytes from the matrix. The purged analytes are trapped on to a specially designed trap and thermally desorbed on to the DB- 624 megabore capillary chromatographic column by back flushing the trap with helium. The compounds are separated into individual compounds with a temperature program of the GC and enter the mass spectrometer where they undergo fragmentation to give characteristic mass spectra. The unknown compounds are identified comparing their mass spectra and retention times with reference compounds, and quantitated by internal standard method. The quantitation data is supported by extensive amount of $Q A / Q C$ such as tuning mass spectrometer to meet bromofluorobenzene (BFB) 
criteria, initial and continuing calibrations verifying daily response factors, method blanks, surrogate recoveries, duplicate analysis, matrix spike and matrix spike duplicate analysis and performing reference standard analysis to verify the dally working standard.

\section{2b) PCB analysis:}

Samples are collected in 50-100 ml glass containers with teflon-lined lid and stored at $4^{\circ} \mathrm{C}$ and analyzed within 14 days.

Transformer o11, waste oil and spill wipe samples are analyzed for PCBs using gas chromatography-electron capture detector (GC-ECD) method. This method is similar to EPA method 608 and is targeted to identify and quantitate seven different mixtures of PCB congeners in the samples.

The method consists of diluting a known weight of the sample with isooctane and removing the interfering compounds with one or more aliquots of concentrated sulfuric acid till the acid layer is almost colorless. All the oil matrix along with other interfering polar compounds are selectively removed from the sample, leaving PCBs in isooctane solvent.

There are two GC-ECD instruments for the analysis of PCBs. Each GC-ECD instrument is calibrated with different concentrations of each PCB mixture to establish linearity. PCBs found in the samples are identified and quantitated by comparing the retention times and chromatographic patterns with the standards. Methods blanks, duplicates, spikes and reference standards are run as part of $\mathrm{QA} / \mathrm{QC}$.

\section{2c) Anions:}

Chloride, nitrate-N and sulfate are analyzed using Dionex Ion-chromatography (IC) with ion suppression and conductivity detection technique.

Monitoring well samples are collected in 500-1000 $\mathrm{ml}$ polypropylene bottles, cooled to $4^{\circ} \mathrm{C}$ and analyzed within 28 days. For nitrate analysis in drinking water analysis, samples are supposed to be analyzed within $48 \mathrm{hrs}$. However, even though holding times were exceeded for nitrate analys is of monitoring well samples, it is expected that the depletion of nitrate will be negligible.

The anions are passed through a anion-exchange polymer column and eluted with carbonate/bicarbonate solution. Then the eluent passes through a ionsuppressing column where the background contribution from the eluent is suppressed, leaving the target anions to be detected by conductivity meter.

Initially, the IC system is calibrated with standards to define the working range of the system. The target anions in the samples are identified and quantitated by comparing the retention times and areas with the standards. Method blanks, duplicates, replicates, spikes and reference standards are routinely analyzed as a part of QA/QC. 
Samples are collected in $1000 \mathrm{ml}$ polypropylene bottles and stabilized with ultra-pure nitric acid to a $\mathrm{pH}$ of $<2$. The samples are analyzed within 6 months, except for mercury, in which case the samples are analyzed within 28 days.

Cadmium, chromium, lead (furnace), copper, iron, manganese, silver, sodium, zinc (flame) and mercury (manual cold vapor) are analyzed with Perkin-Elmer atomic absorption spectrometer. Using the flame technique, the sample containing the target element is nebulized and atomized in an oxy-acetylene flame. At the same time, a beam of light from a element-specific hollow cathode lamp corresponding to the absorption frequency of target element is passed through the flame. The atomized element absorbs the energy specific to that element from the cathode lamp and the intensity of absorption is proportional to the concentration of the element in the sample. Calibration curves are run to establish the linearity of the system and samples are quantitated by comparing with standards.

Using the furnace technique, chemical interference is eliminated in two stages: first by heating the sample at $105-110^{\circ} \mathrm{C}$ to remove moisture and then at $600-900^{\circ} \mathrm{C}$ to burn out any organic matrix. Final atomization is achieved by heating the furnace to $2400-2700^{\circ} \mathrm{C}$. The rest of the technique is similar to the flame method mentioned above. Using this furnace technique, sub-ppb detection limits are possible for water samples.

Using cold vapor technique for mercury, a $100 \mathrm{ml}$ aliquot of the sample is digested with potassium permanganate/persulfate oxidizing solution at $95^{\circ} \mathrm{C}$ for 2 hours to oxidize any organically-bound and/or monovalent mercury to mercury (II) ion state. Excess oxidizing agent is destroyed with hydroxylamine hydrochloride. The mercuric ion later is reduced to elemental mercury with excess stannous chloride which is purged with helium into the absorption cell. The absorption is directly proportional to the concentration of mercury in the sample.

All the above mentioned atomic absorption techniques involve initial calibrations to define the calibration range, continuing calibrations, method blanks, duplicates, replicates, matrix spikes and reference standard analysis as a part of $\mathrm{QA} / \mathrm{QC}$. 
APPENDIX D

TABULATED ANALYTICAL RESULTS 


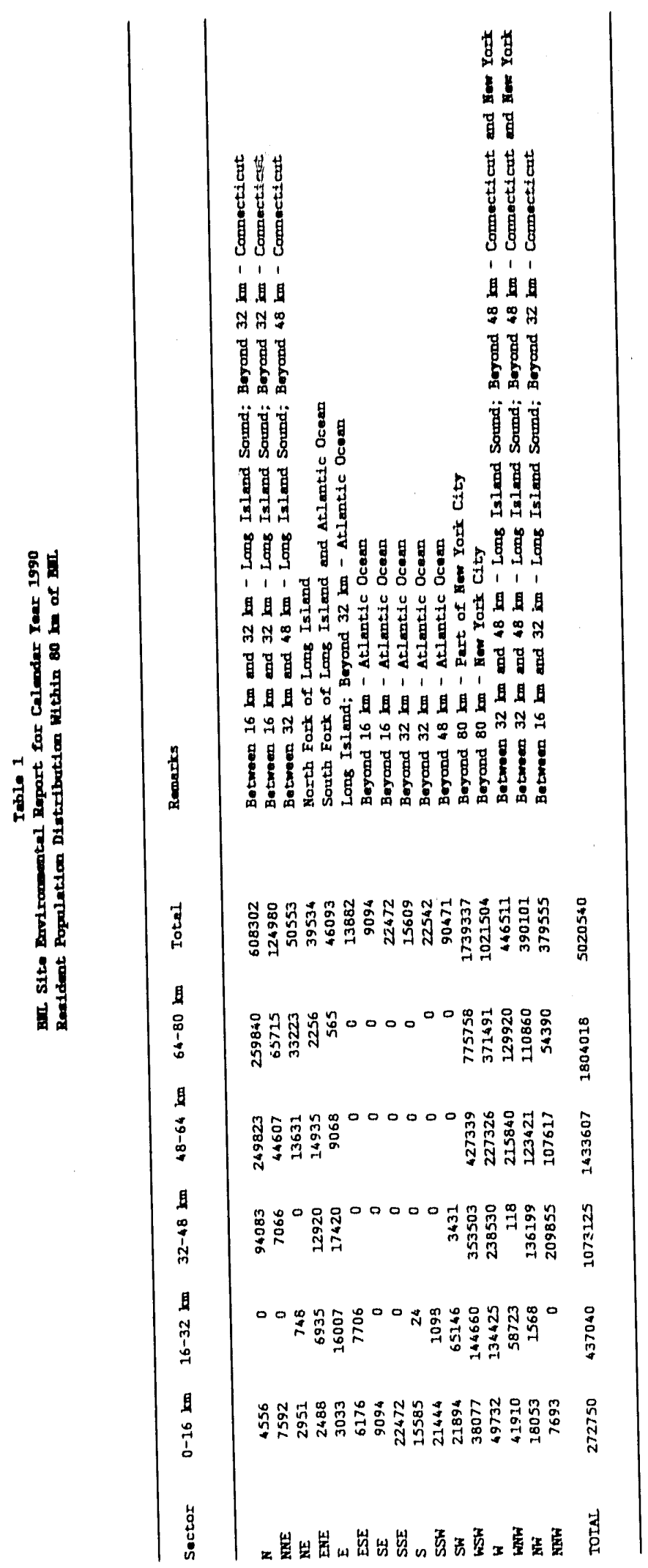


Tabien 2

Dah s1 te Environountal Heport tor Calmdar Yaar 1990

Wind klowe

Jaint Yrequenay Distribution

Poroutagan by Your

YEAR

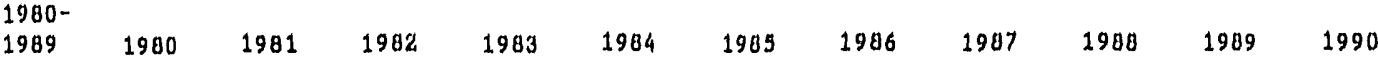

Wind Speod, mps

$\begin{array}{lrrr}\text { GT } & 1 & \text { LE } & 1 \\ \text { GT } & 3 & \text { LE } & 3 \\ \text { GT } & 5 & \text { LE } & 7 \\ \text { GT } & 7 & \text { LE } & 9 \\ \text { GT } & 9 & \text { LE } & 12 \\ \text { GT } & 12 & \text { LE } & 16\end{array}$

$1.01 \quad 0.82$

9.72

23.84

32,13

21,51

9.36

2,20

0.23

\subsection{8}

18.94

30,14

24.45

13,30

4,18

0.48

1907

-

$\begin{array}{rr}1.02 & 1.43 \\ 8.28 & 9.77 \\ 18.71 & 21.60 \\ 28.42 & 29.45 \\ 23.97 & 24.07 \\ 14.21 & 10.61 \\ 4.53 & 2.74 \\ 0.83 & 0.31\end{array}$

1.03
9.88
22.39
33.42
20.51
10.21
2.27
0.10

$\begin{array}{rr}0.91 & 0.53 \\ 9.98 & 0.13 \\ 23.86 & 23.80 \\ 34.40 & 33.55 \\ 21.03 & 23.22 \\ 8.34 & 8.89 \\ 1.30 & 1.65 \\ 0.10 & 0.13\end{array}$

0.59
10.11
29.49
31.53
19.90
6.01
1.50
0.12

1.25

10,70

26.63

1,26
10,42

10,42
24,87

24,07

10,97
6,69

21,86

7,22

1,41

0.90

0,00

1.10
12.05
27.06
32.90
17.21
7.26
1.47

0.89

11,70

26.16

32.52

19.73

7.70

1.19

Gugt iness

Very Unstable
Unstablo
Noutral
Stable

11.47

43,32

12,50

7,58
42.79
14.6

13.49

38.26

16.75

$15.61 \quad 11,19$

$44.95 \quad 40.57$

$6.65 \quad 15.01$

13.64

43.15

12,29

44,78

11,25

12,84

39,69

16,14

7.28

49.69

0.75

45,17

12,55

12.08

44,12
12,86

13.77

$93.44 \quad 33,51 \quad 12,86$

45.37

14,05

26,79

\section{Direotion}

$N$
$N N E$
$N E$
$E N E$
$E$
ESE
SE
SSE
S
SSW
SW
WSW
W
WNW
NW
NNW

$\begin{array}{rrrr}6.06 & 5.78 & 4.39 & 7.83 \\ 5.06 & 4.77 & 3.98 & 5.86 \\ 5.05 & 4.91 & 4.86 & 5.66 \\ 4.01 & 2.97 & 4.37 & 3.84 \\ 3.23 & 2.79 & 3.03 & 3.30 \\ 3.02 & 2.18 & 3.49 & 3.03 \\ 3.01 & 2.64 & 3.83 & 2.56 \\ 3.33 & 3.66 & 3.67 & 3.70 \\ 4.57 & 3.27 & 4.35 & 4.22 \\ 10.40 & 8.47 & 9.42 & 7.92 \\ 10.65 & 11.66 & 8.67 & 13.74 \\ 6.56 & 7.20 & 5.20 & 7.11 \\ 7.21 & 6.15 & 6.50 & 6.53 \\ 10.30 & 10.13 & 13.71 & 8.57 \\ 9.36 & 12.17 & 10.83 & 8.74 \\ 8.17 & 11.24 & 9.98 & 7.37\end{array}$

6.81
5,20
5.70
4,60
3,71
3,74
2.75
3,02
4.73
9.72
9.01
6.71
7.99
9.48
9.99
6.85
7.55
6.43
5. 15
4.07
3.58
3.26
2.89
2. 35
3.89
7.77
13.43
8.13
6,24
8. 38
8. 28

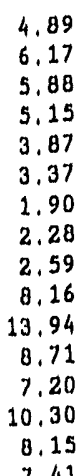

4.88

5.14

$4.78 \quad 5.20$

$4.87 \quad 4.02$

3. $56 \quad 3.43$

$2.65 \quad 3.39$

$2.82 \quad 3.53$

$4,10 \quad 3,11$

$5,42 \quad 5,10$

13,34

7,95

5.58

7.58

10.43
8.40

8,40

9.78

0.61
6,05

6,05

9,37
10,12

10,12
7,58

$\begin{array}{rrr}4.85 & 5.69 & 5.62 \\ 3.44 & 4.14 & 3.83 \\ 3.78 & 4.66 & 5.55 \\ 2.11 & 4.20 & 3.28 \\ 1.87 & 3.24 & 2.41 \\ 2.04 & 3.09 & 2.46 \\ 3.47 & 3.88 & 3.60 \\ 3.36 & 3.99 & 3.67 \\ 6.37 & 5.64 & 6.55 \\ 16.74 & 12.56 & 16.73 \\ 10.02 & 9.66 & 9.75 \\ 5.69 & 5.38 & 6.26 \\ 0.90 & 7.73 & 6.91 \\ 11.46 & 11.18 & 8.87 \\ 8.66 & 7.80 & 7.39 \\ 7.23 & 7.17 & 7.12\end{array}$

$\begin{array}{rrrr}7.58 & 8.66 & 7.80 & 7.39 \\ 7.23 & 7.17 & 7.12\end{array}$

LE: Less than or equal to.

GT: Greather than.

The hoight of the wind vane was ohanged from $355 \mathrm{ft}$, to $290 \mathrm{ft}$, in May 1981. 
Tablo 3

BNL S1te Environmental Report for Oalendar Year 1990 Summary of Dally Mean Ollmatology Data at BNI, for 1990

\begin{tabular}{|c|c|c|c|c|}
\hline \multirow{2}{*}{ Month } & \multicolumn{3}{|c|}{ Temperature, oC } & \multirow{2}{*}{$\begin{array}{c}\text { Precipltation } \\
\mathrm{cm}\end{array}$} \\
\hline & Min & $\operatorname{Max}$ & Avg & \\
\hline January & $-8,3$ & 15.2 & 2.9 & 13,31 \\
\hline February & -17.6 & 14.9 & 1.8 & 7.42 \\
\hline March & -15.2 & 27.8 & 4.4 & 5.44 \\
\hline Apr11 & -11.7 & 31.8 & 8.7 & 12.60 \\
\hline May & -0.3 & 25.8 & 13.2 & 16.56 \\
\hline June & 5.2 & 29.1 & 19.3 & 10.03 \\
\hline July & 9.7 & 33.3 & 22.5 & 6.71 \\
\hline August & 12.2 & 31.1 & 22.3 & 17.15 \\
\hline September & 1.7 & 29.2 & 17.0 & 7.72 \\
\hline October & -2.8 & 26.7 & 14.1 & 18.21 \\
\hline November & -4.6 & 25.0 & 7.6 & 4.52 \\
\hline December & -8.0 & 15.2 & 4.1 & 14,99 \\
\hline Annual & -17.6 & 33.3 & 11.5 & 134.65 \\
\hline $\begin{array}{l}40 \text { Year } \\
\text { Average }\end{array}$ & & & 9.8 & 123.01 \\
\hline
\end{tabular}

Note: Minimum and maximun temperatures 11sted for each month represent: the lowest and highest temperature observed during the month. 


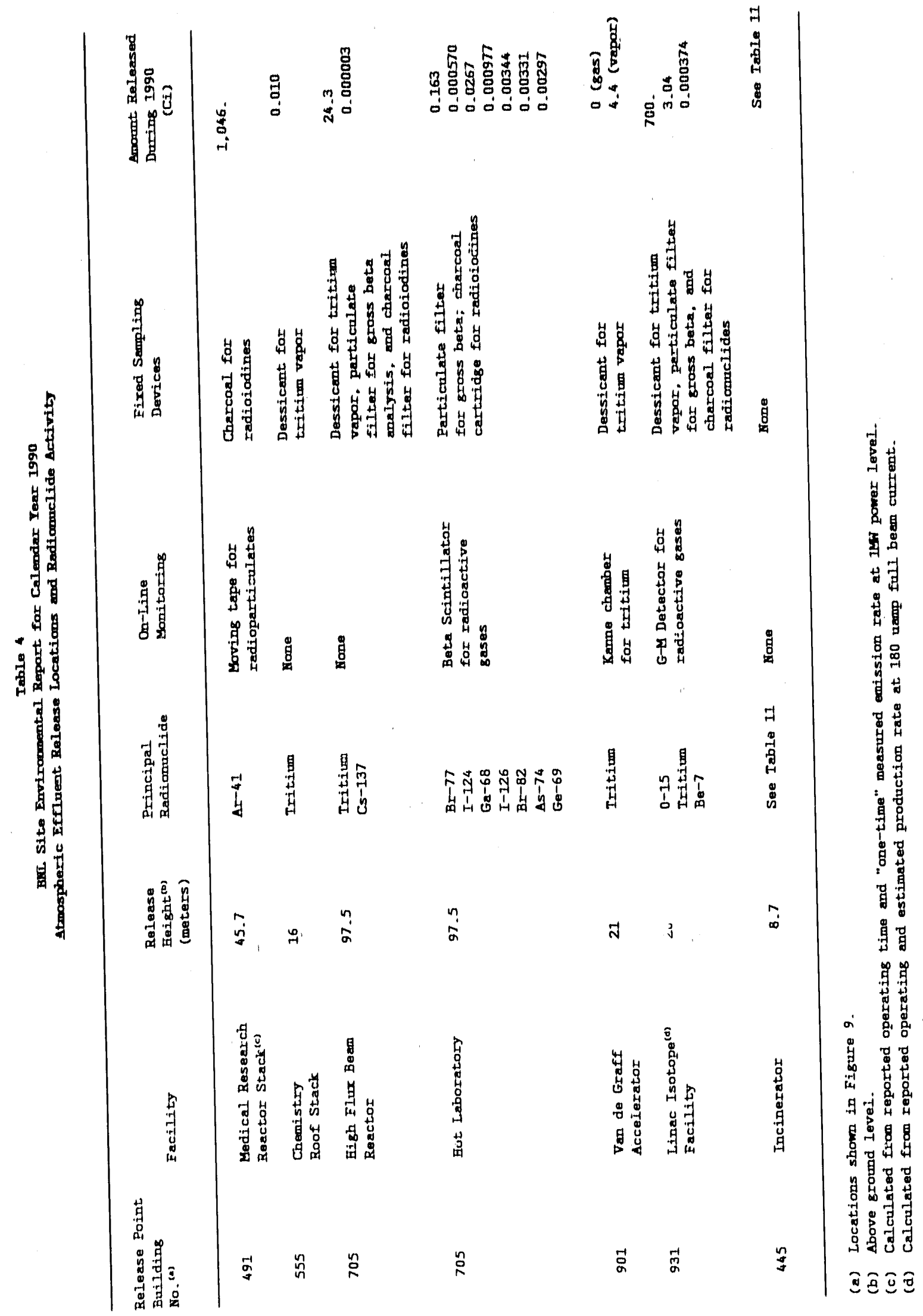


Table 5

BNL Site Environmental Report for Calendar Year 1990 Noble Gas Releases from the Medical Research Reactor (MRR) and the Brookhaven Linear Isotope Production Facllity (BLIP)

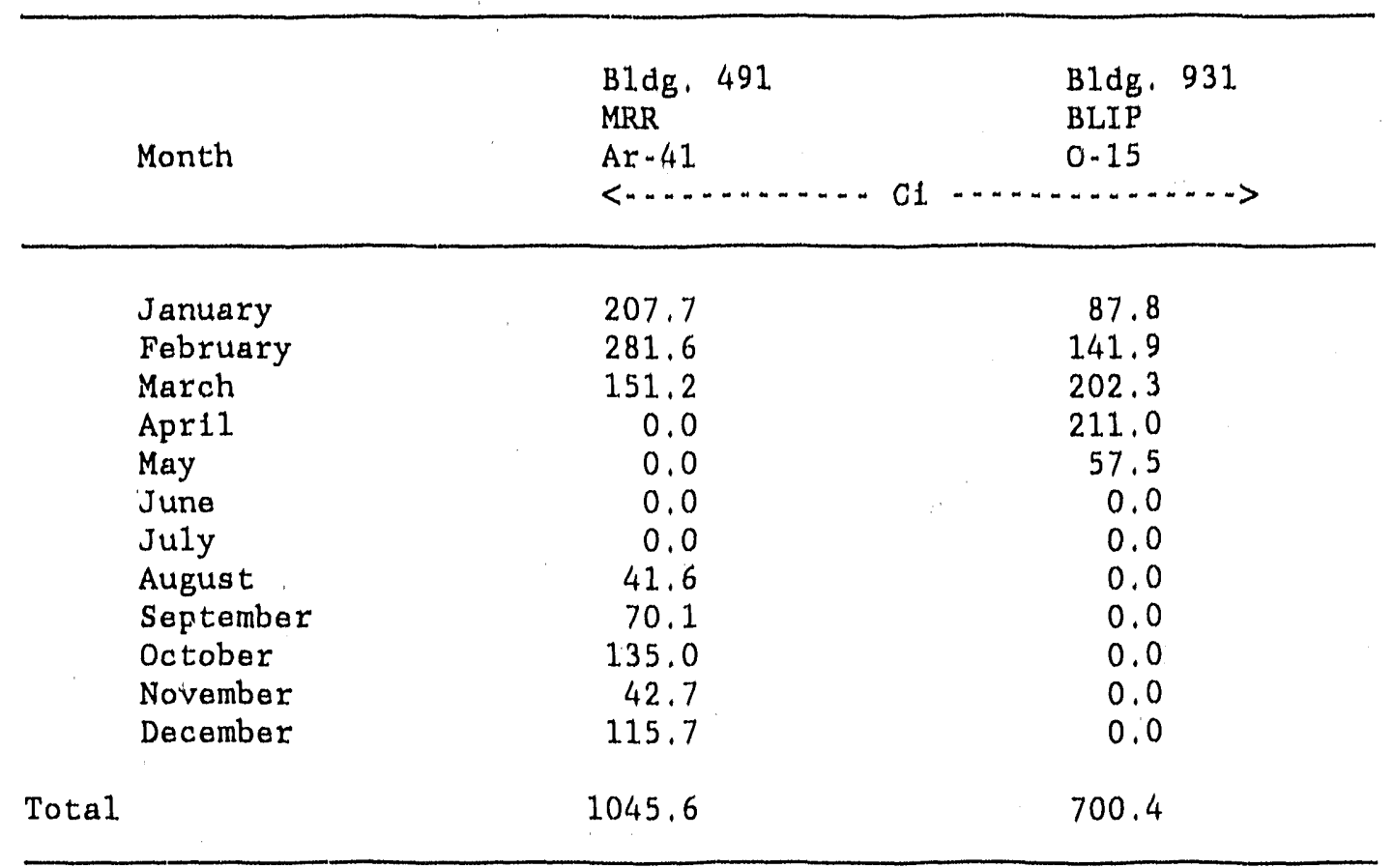

Notes:

1. The MRR did not operate from April through July while a new source of secondary cooling water was provided.

2. The BLIP Facility did not operate from May 13, 1990 to the end of the calendar year due to lack of beam from the Linac. 
Table 6

BNL Site Environmental Report for Calendar Year 1990

Tritium Releases from 10-m Stacks

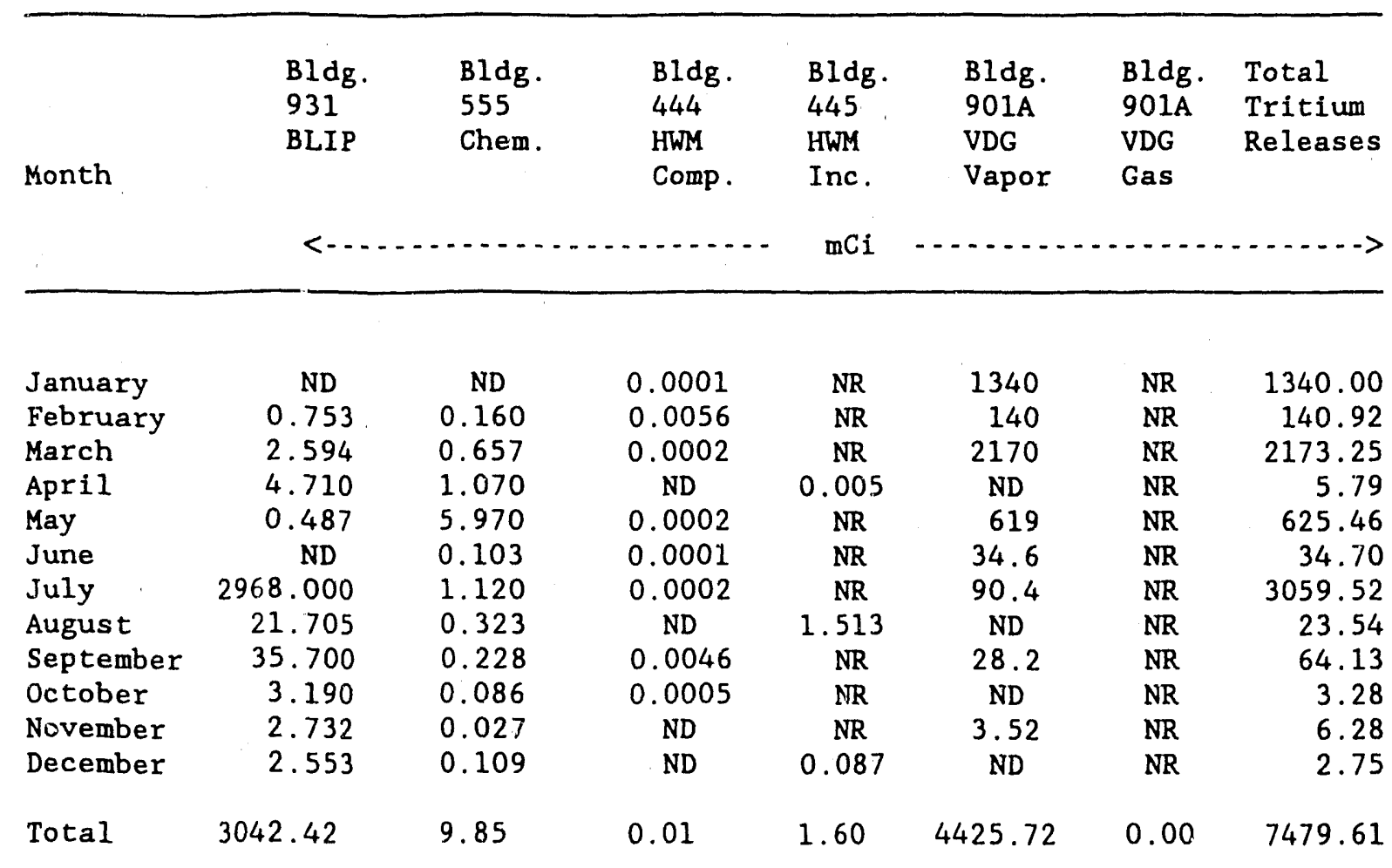

ND: Not detected.

NR: No release. Facility did not operate in 1990. 
Table 7

BII Site Bnvirowental Report for Calendar Year 1990 Airborne Efflueat Disesions fro Building 750 vis the Building 705 stack

\begin{tabular}{|c|c|c|c|c|c|c|c|c|c|}
\hline \multirow[b]{2}{*}{ Month } & \multirow{2}{*}{$\begin{array}{l}\text { Total } \\
\text { Stack Flow } \\
\text { cc }\end{array}$} & \multicolumn{4}{|c|}{ Total Activity } & \multicolumn{4}{|c|}{ Average Alr Concentration } \\
\hline & & B-3 & $\mathrm{Be}-7$ & $\begin{array}{l}\mathrm{Cs}-137 \\
\mathrm{uCl}\end{array}$ & $\begin{array}{c}5 c-46 \\
---->\end{array}$ & $\begin{array}{l}\mathrm{B}-3 \\
<-\cdots-\cdots\end{array}$ & $\mathrm{Be}-7$ & $\begin{array}{l}\mathrm{Cs}^{-137} \\
\mathrm{pC} \mathrm{i}_{1 / \mathrm{m}^{3}}\end{array}$ & $\begin{array}{c}S c-46 \\
\ldots\end{array}$ \\
\hline January & $1.431 E+13$ & 840030 & 0.22 & 0.10 & 0.00 & 58713 & 0.015 & 0.007 & ND \\
\hline February & $2.280 E+13$ & 672930 & 0.00 & 0.32 & 0.08 & 47034 & ND & 0.023 & 0.006 \\
\hline March & $2.130 \mathrm{E}+13$ & 730430 & 0.00 & 0.09 & 0.00 & 51053 & ND & 0.006 & ND \\
\hline April & $2.758 \mathrm{E}+13$ & 960710 & 0.12 & 0.33 & 0.00 & 67148 & 0.008 & 0.023 & ND \\
\hline May & $2.212 E+13$ & 1137700 & 0.00 & 0.13 & 0.00 & 79518 & ND & 0.009 & ND \\
\hline June & $2.017 E+13$ & 1458000 & 0.00 & 0.10 & 0.00 & 101905 & ND & 0.007 & ND \\
\hline July & $2.873 E+13$ & 6960100 & 0.00 & 0.14 & 0.00 & 486469 & ND & 0.010 & ND \\
\hline August & $2.036 \mathrm{E}+13$ & 4018000 & 0.00 & 0.18 & 0.00 & 280834 & ND & 0.013 & ND \\
\hline September & $2.280 \mathrm{E}+13$ & 998000 & 0.00 & 0.14 & 0.00 & 69754 & ND & 0.010 & ND \\
\hline October & $2.723 \mathrm{E}+13$ & 2229800 & 0.00 & 0.34 & 0.00 & 155849 & ND & 0.024 & ND \\
\hline November & $1.978 \mathrm{E}+13$ & 1437600 & 0.28 & 0.48 & 0.00 & 100479 & 0.019 & 0.034 & ND \\
\hline December & $2.351 \mathrm{E}+13$ & 2824100 & 0.00 & 0.30 & 0.00 & 197387 & ND & 0.021 & ND \\
\hline Tot 91 & $2.707 E+14$ & 24267400 & 0.61 & 2.66 & 0.08 & & & & \\
\hline Annual Avg. & & & & & & $3.96 \mathrm{E}+04$ & 0.002 & 0.010 & 0.0003 \\
\hline \multicolumn{10}{|c|}{ DOE Order 5400.5} \\
\hline
\end{tabular}

ND: Not Detected. 


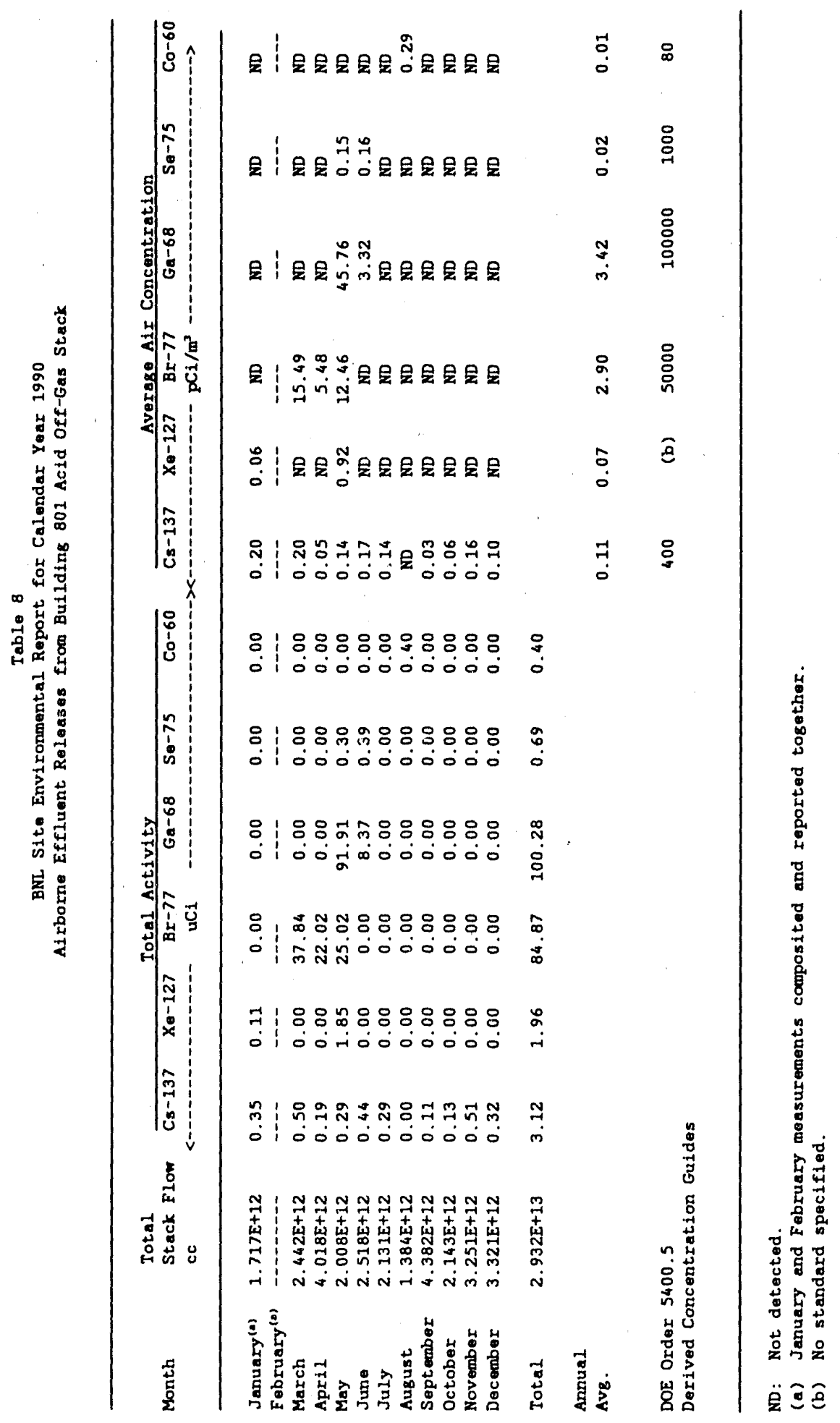




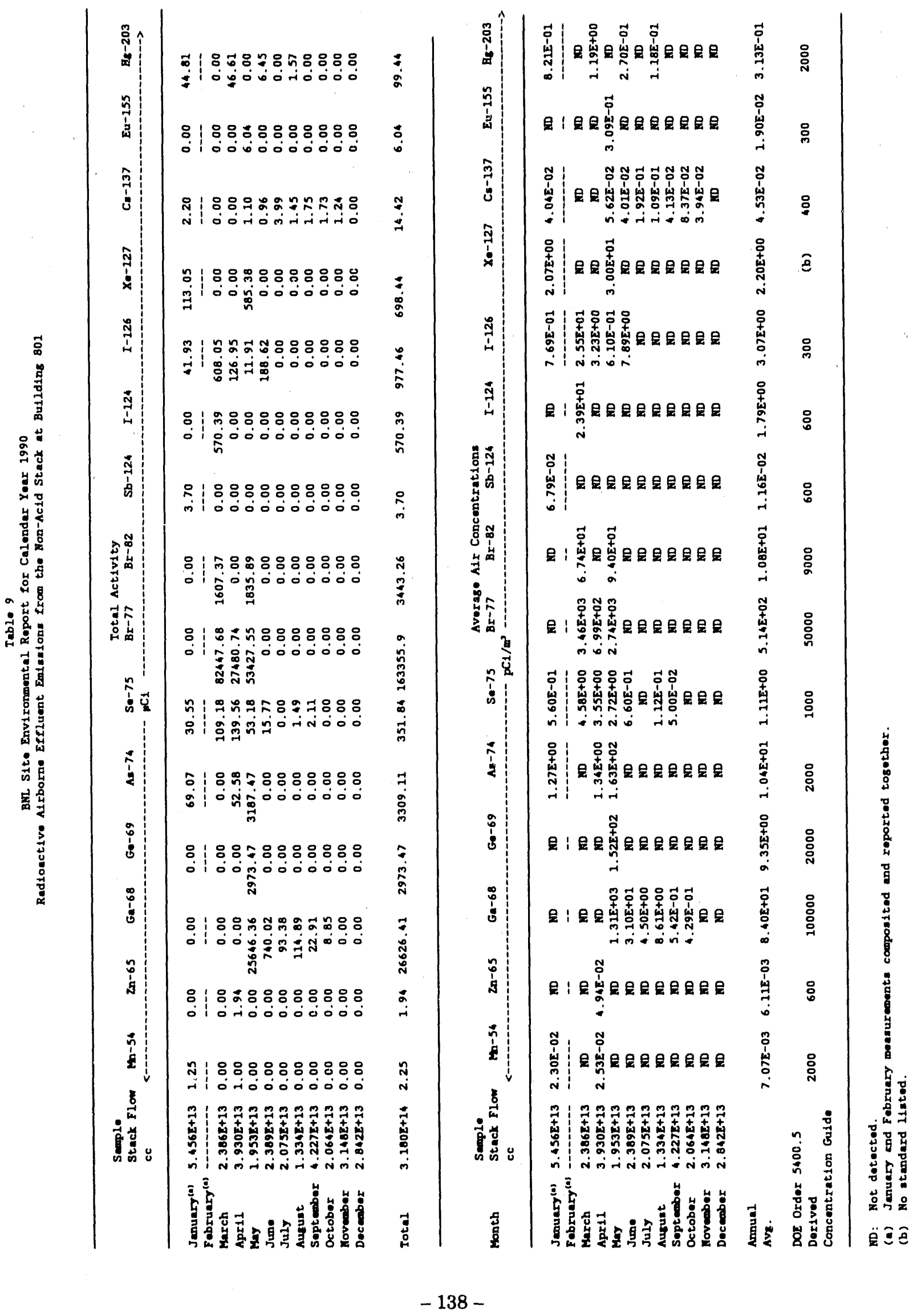




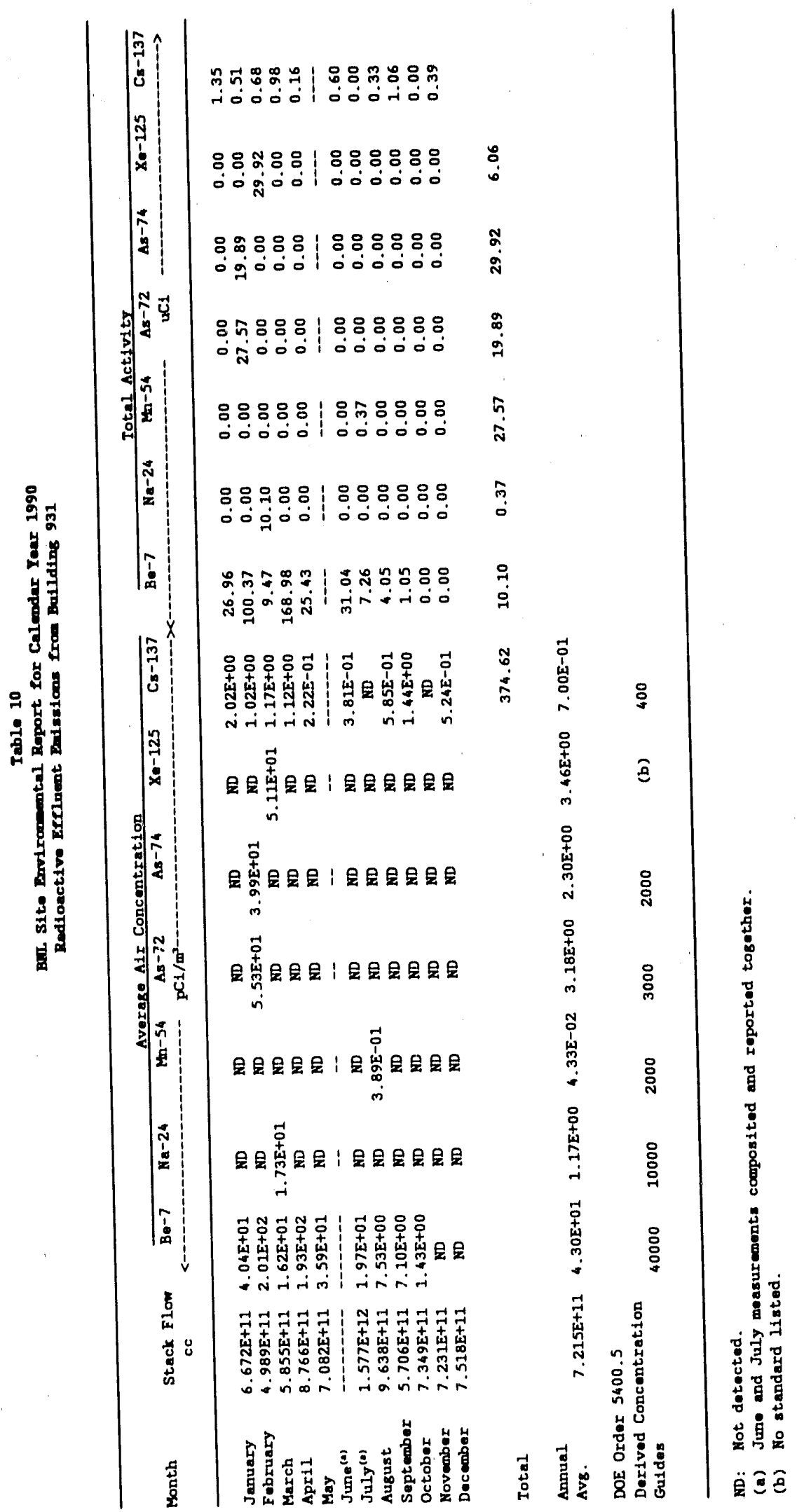


Table 11

BNL Site Environmental Report for Calendar Year 1990

Estimated Radioactivity in Incinerated Material

\begin{tabular}{|c|c|c|c|c|c|c|c|c|}
\hline \multirow[t]{2}{*}{ Month } & $\mathrm{H}-3$ & $I-125$ & $C-14$ & \multirow{2}{*}{$\begin{array}{l}\mathrm{Tl}-201 \\
\mathrm{mCl}\end{array}$} & $\mathrm{Sn}-113 \mathrm{~m}$ & $\mathrm{Cr}-51$ & $S n-117 m$ & Co -57 \\
\hline & $\ldots . .$. & $-\cdots$ & $-\cdots+-\infty$ & & \multicolumn{4}{|c|}{$\ldots \ldots \ldots \ldots \ldots \ldots$} \\
\hline January & $\mathrm{RNI}$ & 0.005 & 0.100 & RNI & RNI & 0.001 & RNI & RNI \\
\hline February & $-\cdots$ & -- & $\cdots$ & $\ldots$ & $\cdots$ & $\cdots$ & $\cdots$ & $-\cdots$ \\
\hline March & -- & $\cdots$ & $\cdots$ & -- & $\cdots$ & $\cdots$ & $\cdots$ & $\cdots$ \\
\hline April & 0.005 & 0.005 & 0.005 & 0.005 & RNI & RNI & RNI & 0.002 \\
\hline May & $\cdots$ & $\cdots$ & $\cdots$ & $\cdots$ & $\cdots$ & $\cdots$ & $\cdots$ & $\cdots$ \\
\hline June & $\cdots$ & $\cdots$ & $\cdots$ & $\cdots$ & $\ldots$ & $\cdots$ & $\cdots$ & $\cdots$ \\
\hline July & $\cdots$ & $\cdots$ & $\cdots$ & $\cdots$ & $\cdots$ & $\cdots$ & $\cdots$ & $\cdots$ \\
\hline August & 1.513 & 0.032 & 0.030 & RNI & RNI & RNI & RNI & RNI \\
\hline September & $\cdots$ & $\cdots$ & $\cdots$ & $\cdots$ & $\cdots$ & -- & $\cdots$ & $\cdots$ \\
\hline October & RNI & 0.005 & RNI & RNI & RNI & RNI & RNI & RNI \\
\hline November & $\cdots$ & $\cdots$ & $\cdots$ & $\cdots$ & $\cdots$ & $\cdots$ & $\cdots$ & $\cdots$ \\
\hline December & 0.087 & RNI & RNI & RNI & 0.200 & RNI & 0.003 & 0.200 \\
\hline Total & 1.604 & 0.047 & 0.135 & 0.005 & 0.200 & 0.001 & 0.003 & 0.202 \\
\hline
\end{tabular}

Note: The incinerator operated only in January, April, August, October, and December. RNI: Radionuclide not incinerated. 
Table 12

BRL Site Eavironeontial Report for Calendar Year 1990

BIL Lnvironental Permita

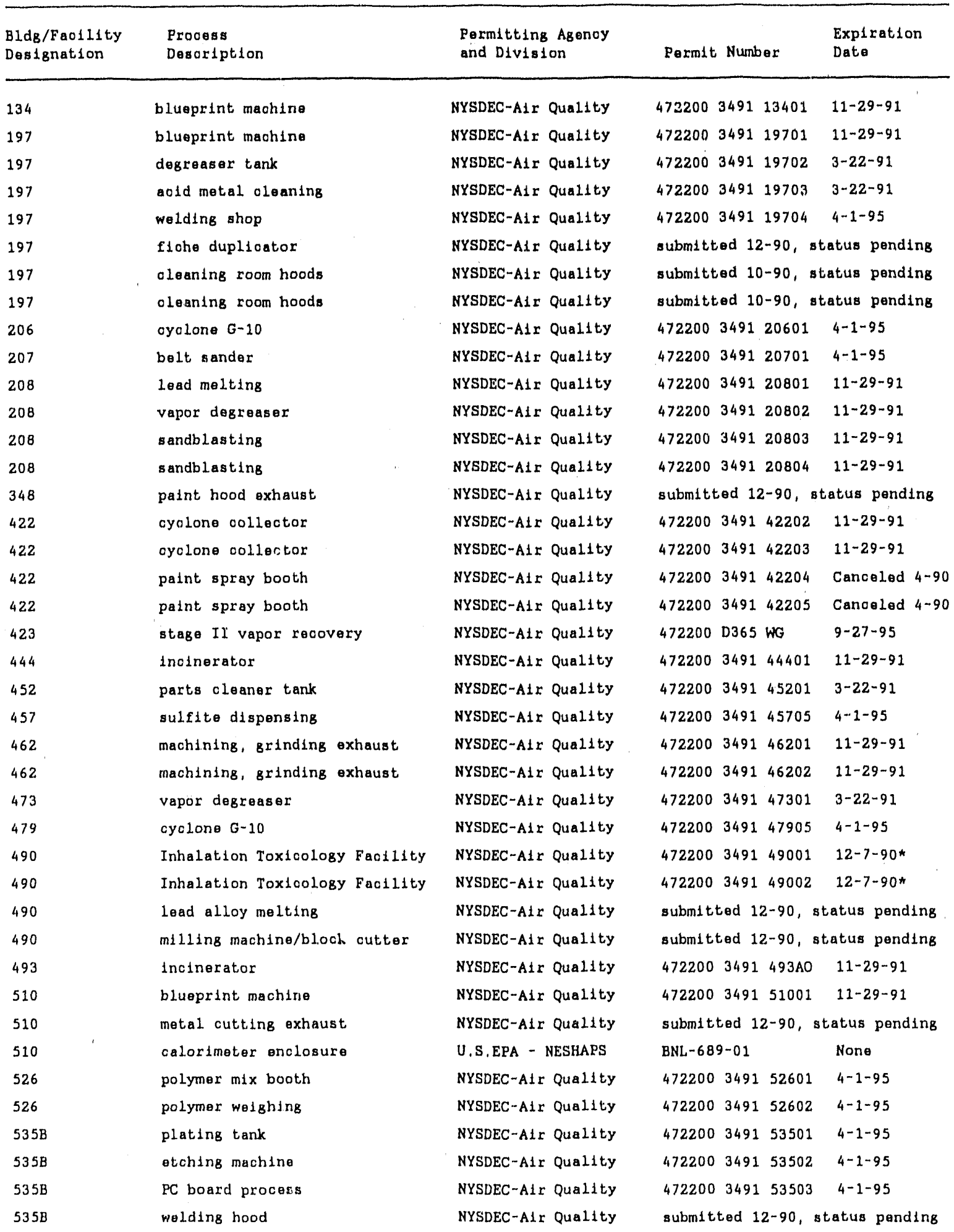


Tablo 12 (Contlunad)

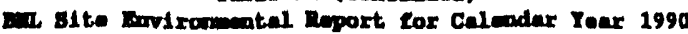

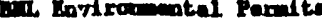

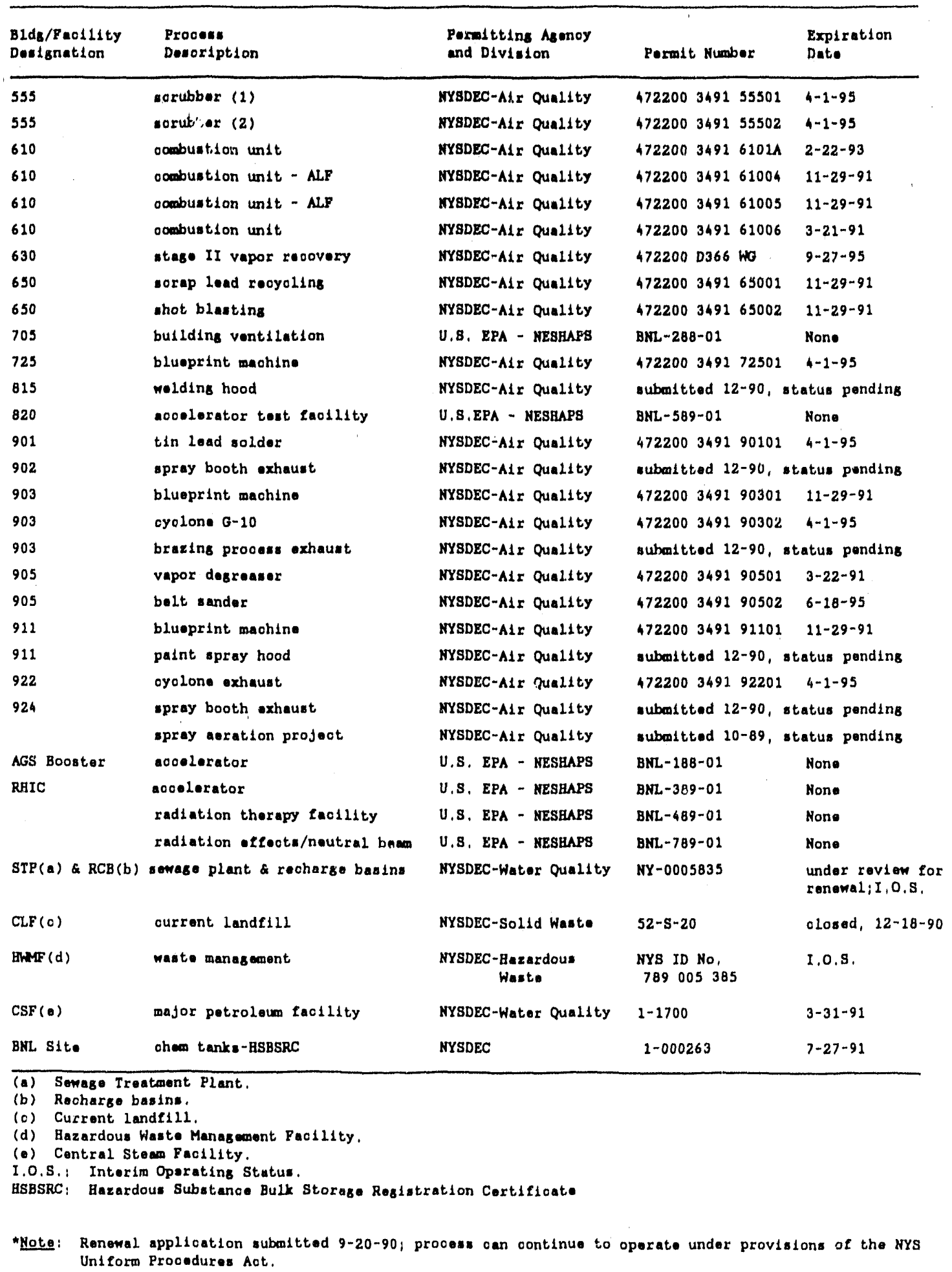


Table 13

BRL 81te Bnvirormantal Kaport for Calondar Yaar 1990

Sowago Truateont Plant Eefluent Gross Mlpha, Gross Botia, and Tritjie Conoentrations

\begin{tabular}{|c|c|c|c|c|c|c|c|c|c|c|}
\hline \multirow[b]{2}{*}{ Month } & \multirow[b]{2}{*}{$\begin{array}{l}\text { Flow, } \\
\text { L1ters }\end{array}$} & \multicolumn{3}{|c|}{ Gros: Alpha } & \multicolumn{3}{|c|}{ Grove Bota } & \multicolumn{3}{|c|}{ Tr1tium } \\
\hline & & AvB. & Min. & Max. & Avg. & $\begin{array}{l}\text { Min. } \\
\mathrm{pCl} / \mathrm{L}-\cdots\end{array}$ & Max. & AVB. & Min. & Max, \\
\hline January & $8.82 E+07$ & 0.05 & $-1,28$ & 1.28 & 3.17 & -6.42 & 15,90 & 555.21 & -400.00 & 6420.00 \\
\hline February & $7.07 E+07$ & 0.64 & $-1,02$ & 2.05 & 5.60 & -0.38 & 9.63 & 226.59 & -586.00 & 1240.00 \\
\hline Maroh & $7.85 E+07$ & 0.36 & -1.02 & 2.30 & 4.65 & -1.51 & 10,60 & -53.92 & $-1160,00$ & 1230.00 \\
\hline Apri11 & $0.12 E+07$ & 0.35 & -1.02 & 2.56 & 6,01 & 1.32 & 10,20 & -195.36 & -1890.00 & 1270.00 \\
\hline May & $9.30 E+07$ & 0.30 & -0.77 & 2.30 & 4.11 & -2.00 & 9,44 & 658.48 & -2440.00 & 5590,00 \\
\hline June & $9.36 E+07$ & 0.05 & -1.28 & 1,54 & 5.07 & 0,00 & 14.90 & 750,54 & -69.50 & 3710,00 \\
\hline July & $1.01 E+08$ & 0.37 & -1.02 & 1.79 & 3.99 & $-0,94$ & 8.50 & 3408.04 & $-173,00$ & 11700,00 \\
\hline August & 1. $26 \mathrm{E}+08$ & 0.16 & -1.28 & 2.30 & 5.04 & $-1,13$ & 9.25 & 3242.70 & 1410.00 & 20900,00 \\
\hline September & $6.93 E+07$ & 0.03 & $-1,28$ & 1.54 & 3.84 & 1,13 & 9.25 & 1916.00 & 470.00 & 3720,00 \\
\hline Ootobar & $8.57 E+07$ & 0.46 & $-1,54$ & 2.05 & 9.26 & $-1,70$ & 92,00 & 1596.74 & $-103,00$ & 4940,00 \\
\hline November & $6.67 E+07$ & 0,12 & -1.54 & 2.05 & 4.18 & 0,94 & 14,20 & 1259.10 & 13.30 & 4850,00 \\
\hline December & $6.49 E+07$ & 0.22 & -0.51 & 1.54 & 3.83 & 0,00 & 10.80 & 563.66 & -196.00 & 1350,00 \\
\hline Avg, Cono. & & 0.26 & & & 4.92 & & & 1295.4 & & \\
\hline $\begin{array}{l}\text { Total Reloaso } \\
\text { (L or } m C 1 \text { ) }\end{array}$ & $1,02 E+09$ & 0.26 & & & 5.01 & & & 1319.9 & & \\
\hline
\end{tabular}

Samplo Looation Station EA - Chlorine House Effluent

\begin{tabular}{|c|c|c|c|c|c|c|c|c|c|c|}
\hline January & $7.96 E+07$ & 0.77 & $-1,28$ & 3.07 & 12.89 & $-0,19$ & 21.00 & 102.78 & $-885,00$ & 1070,00 \\
\hline Fobruary & $7.10 \mathrm{E}+07$ & 0.98 & $-1,78$ & 2.56 & 10.72 & 2.46 & 17,00 & 284.23 & -303.00 & 895.00 \\
\hline Maroh & $7.37 \mathrm{E}+07$ & 0.81 & -0.26 & 2.56 & 9.58 & 2.46 & 16,80 & 71.60 & $-1160,00$ & 1420,00 \\
\hline Apri1 & $7.86 E+07$ & 0.66 & -1.79 & 2.30 & 8.02 & 3.40 & 13,80 & $-61,38$ & $-1700,00$ & 1810,00 \\
\hline May & $8.89 E+07$ & 0.44 & -0.77 & 2.30 & 7.24 & 3.21 & 12.30 & 379.84 & -2410.00 & 4070,00 \\
\hline June & $8.70 E+07$ & 0.06 & -1.79 & 2.05 & 6.66 & 1.13 & 13.40 & 835.73 & $-168,00$ & 4560,00 \\
\hline July & $8.89 E+07$ & 0.14 & -1.79 & 2.05 & 6.68 & 3.97 & 10.60 & 3200.06 & 509.00 & 8870,00 \\
\hline August & $8.72 E+07$ & 0.18 & -1.79 & 2.30 & 7.33 & 2.83 & 14.80 & 3433.04 & 966.00 & 14300,00 \\
\hline September & $6.80 E+07$ & 0.38 & -1.54 & 1.79 & 5.20 & 2.27 & 9.07 & 1747.72 & 246.00 & 3580.00 \\
\hline Octobar & $7.12 \mathrm{E}+07$ & 0.20 & $-1,28$ & 1.28 & 5.98 & 1.32 & $10 \cdot 40$ & 1608.48 & -380.00 & 3940.00 \\
\hline November & $5.42 E+07$ & 0.21 & -1.02 & 2.30 & 5.12 & -1.13 & 10.60 & 6072.84 & 3970.00 & 8670,00 \\
\hline Deoumber & $5.24 E+07$ & 0.31 & -0.51 & 2.30 & 7.53 & 2.64 & 15.50 & 1773.65 & -216.00 & 5090.00 \\
\hline Avg, Cono. & \multicolumn{4}{|c|}{0.43} & 7.81 & \multicolumn{5}{|c|}{1526.52} \\
\hline $\begin{array}{l}\text { Total Release } \\
\text { (L or } \mathrm{mC} 1 \text { ) }\end{array}$ & $9.01 E+08$ & \multicolumn{2}{|l|}{0.30} & \multicolumn{4}{|c|}{7.03} & \multicolumn{2}{|c|}{1374,87} & \\
\hline SPDES Limits & \multicolumn{3}{|c|}{$3,0(R a-226)$} & \multicolumn{3}{|c|}{1000} & \multicolumn{3}{|c|}{ Not Listed } & \\
\hline \multicolumn{11}{|l|}{ NYS DrinkinB } \\
\hline Wator Standard & \multicolumn{3}{|c|}{15} & \multicolumn{3}{|c|}{50} & \multicolumn{3}{|c|}{20000} & \\
\hline Typlcal MDL & \multicolumn{3}{|c|}{2.3} & \multicolumn{3}{|c|}{6} & \multicolumn{3}{|c|}{1000} & \\
\hline
\end{tabular}

MDL: Minimum detection $11 \mathrm{mit}$. 
Tabl. 14

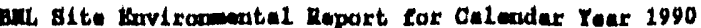

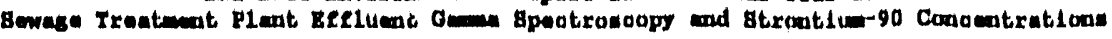

\begin{tabular}{|c|c|c|c|c|c|c|c|c|c|c|c|c|}
\hline Month & $\begin{array}{l}\text { Flow, } \\
\text { Litors }\end{array}$ & Bo-7 & $00-60$ & $\mathrm{Ca}+137$ & $k-40$ & $c a+139$ & $\begin{array}{l}\mathrm{Co-5B} \\
\mathrm{pC} 1 / \mathrm{L}\end{array}$ & $2 n-65$ & $I-131$ & $8 r-90$ & $\mathrm{Co}-37$ & $\mathrm{Na}-2 \mathrm{Z}$. \\
\hline
\end{tabular}

Samplo Looation otation DA - Clarifior Effluent

\begin{tabular}{|c|c|c|c|c|c|c|c|c|c|c|c|c|}
\hline January & $0.82 E+07$ & 0,32 & 0.05 & 0.20 & 2.54 & ND & ND & ND & ND & 0.12 & ND & ND \\
\hline February & $7,07 E+07$ & ND & 0,09 & 0.42 & 3.80 & 0.03 & ND & ND & ND & 0,60 & ND & $N D$ \\
\hline Maroh & $7.85 E+07$ & ND & 0,09 & 0.24 & 2.74 & ND & 0,09 & ND & ND & -0.09 & ND & ND \\
\hline Apri1 & B. 12E+07 & 0.54 & 0,06 & 0.20 & 2.09 & $N D$ & ND & ND & ND & 0.01 & ND & ND \\
\hline May & $9,30 \mathrm{E}+07$ & 0.37 & 0,02 & 0.23 & 2.51 & 0,04 & ND & ND & ND & $-0,10$ & ND & ND \\
\hline Juna & $9.36 \mathrm{E}+07$ & ND & 0.10 & 0,18 & 1,85 & ND & ND & ND & ND & 0.05 & ND & ND \\
\hline July & $1,01 E+0 \theta$ & ND & 0.03 & 0.21 & 3,06 & ND & ND & ND & ND & $-0,12$ & ND & ND \\
\hline August & $1.26 E+08$ & ND & ND & 0.14 & 1.64 & ND & ND & ND & ND & 0.00 & ND & ND \\
\hline Septombor & $6.93 \mathrm{E}+07$ & ND & ND & 0.30 & 2.70 & ND & ND & ND & ND & NR & ND & ND \\
\hline Ootober & $8,57 E+07$ & ND & 0,06 & 0.14 & 1,04 & ND & ND & 0.05 & 6,95 & $\mathrm{NR}$ & ND & ND \\
\hline November & $6.67 E+07$ & ND & 0.10 & ND & 4.15 & ND & ND & ND & ND & NR & ND & ND \\
\hline Deoenbar & $6.49 E+07$ & ND & 0,12 & 0,08 & ND & ND & ND & ND & ND & NR & ND & ND \\
\hline Avs, Cono, & $8.49 E+07$ & 0.10 & 0.06 & 0,20 & 2.52 & 0.01 & 0.01 & 0.00 & 0,58 & 0.05 & ND & DD \\
\hline Total Reloase & $1.02 E+09$ & 0,11 & 0.06 & 0,20 & 2.57 & 0.01 & 0.01 & 0,00 & 0.60 & 0,04 & 0.00 & 10 \\
\hline
\end{tabular}

(L or $\mathrm{mCl}$ )

Samplo Looation Station EA - Chlorine House Effluent

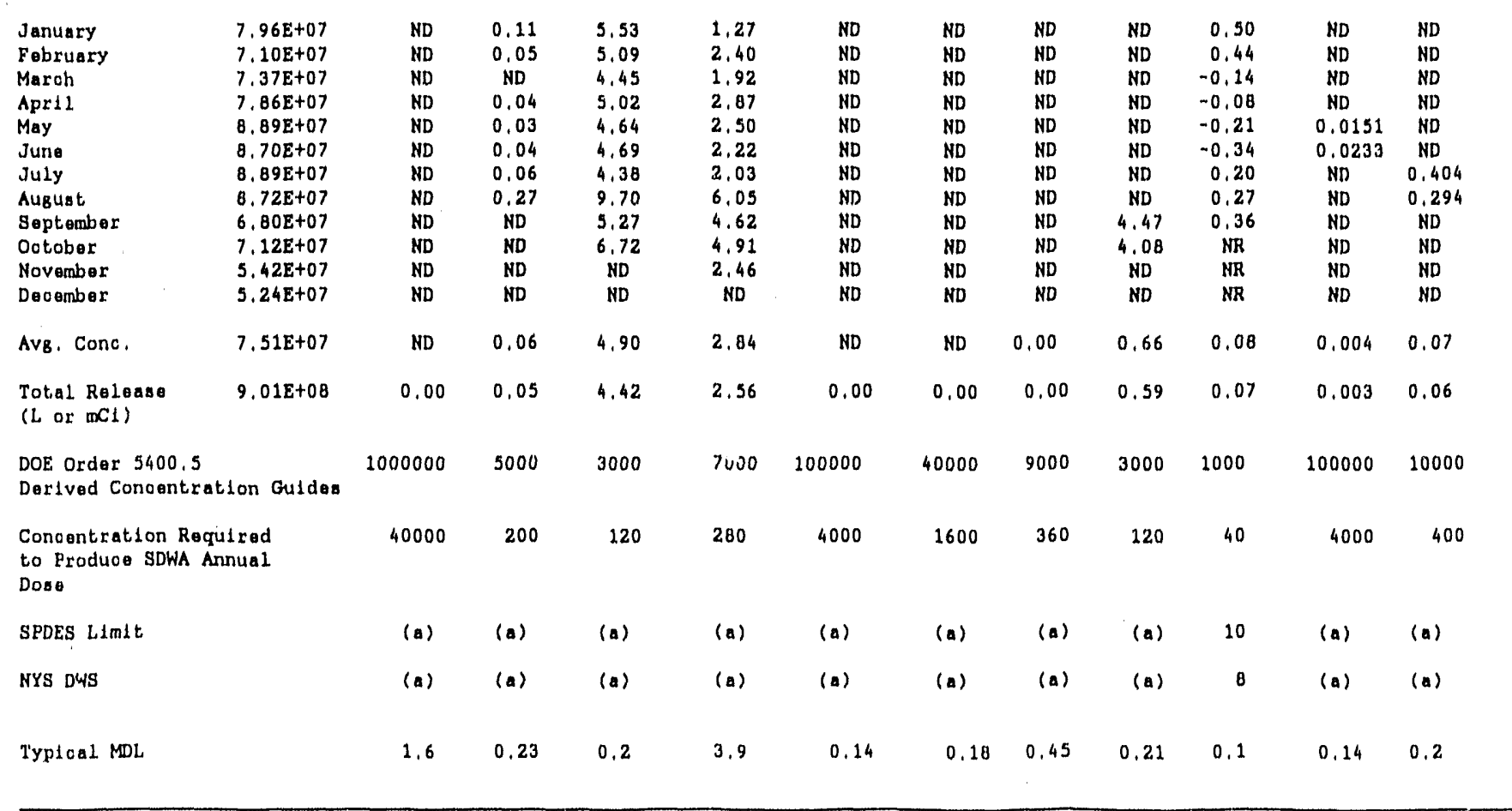

NR: Not deteoted,

ND: Result not reportad by Contractor Laboratory.

ML: Miniram deteotion $11 \mathrm{mit}$.

(a) No standard speolfied. 
Table 15

BNL S1te Environmental Report for Calendar Year 1990

Sewage Treatment Plant(a)

Average Water Quallty and Metals Data

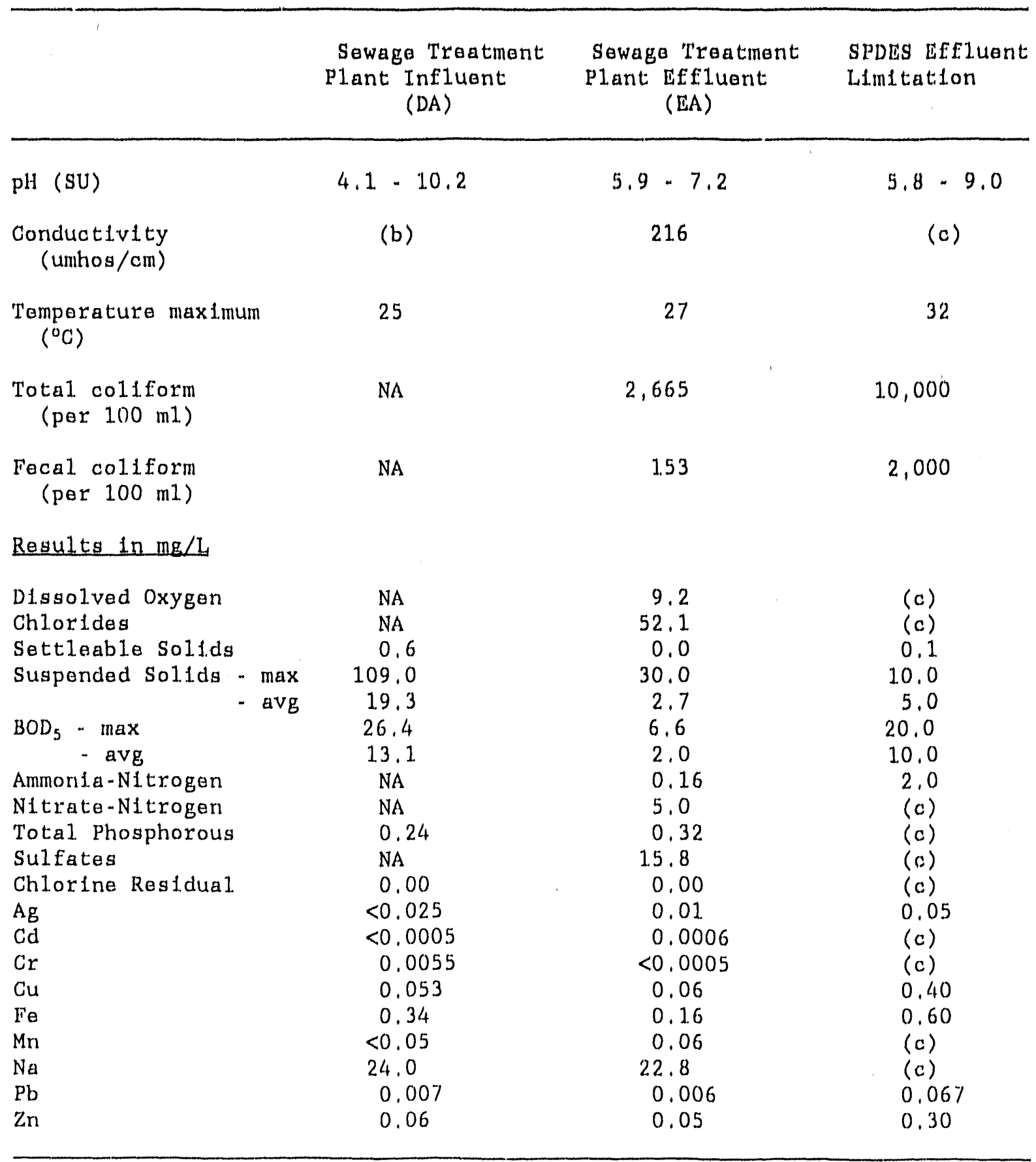

NA: Not Analyzed.

(a) Locations shown in Figure 11 .

(b) Metered.

(c) Effluent Iimftation not spectfied. 
Table 16

BNL 81te Environmental Report for Oalendar Year 1990

spDEs Complianoe for Sowage Treatment plant Efluent (Outfal1 001)

\begin{tabular}{|c|c|c|c|}
\hline Parameter & $\begin{array}{l}\text { Permltted } \\
\text { Frequency } \\
\text { of Sample/Yr }\end{array}$ & $\begin{array}{l}\text { Aotual } \\
\text { Frequency } \\
\text { of Sample/Yr }\end{array}$ & $\begin{array}{l}\text { No, of } \\
\text { Exooodanoes } \\
\text { (por yr) }\end{array}$ \\
\hline Temparaturo & 250 & 250 & 0 \\
\hline Gross $\beta$ & 250 & 250 & 0 \\
\hline$B O D_{3}$ & 12 & 28 & 0 \\
\hline $\mathrm{pH}(\mathrm{M} \perp \mathrm{n})$ & 365 & 365 & 0 \\
\hline $\mathrm{pH}(\operatorname{Max})$ & 365 & 365 & 0 \\
\hline Susponded Sol1ds & 12 & 54 & 5 \\
\hline Sottloablo Solids & 250 & 250 & 0 \\
\hline Ammonla-N1trogan & 12 & 12 & 0 \\
\hline Cu (concontration) & 12 & 12 & 0 \\
\hline $\mathrm{Cu}$ (loading) & 12 & 12 & 0 \\
\hline Fe (concentration) & 12 & 12 & 0 \\
\hline $\mathrm{Pb}$ (concentration) & 12 & 12 & 0 \\
\hline $\mathrm{Pb}$ (loading) & 12 & 12 & 0 \\
\hline $\mathrm{Ag}$ (concentration) & 12 & 12 & 0 \\
\hline $\mathrm{Ag}$ (loading) & 12 & 12 & 0 \\
\hline $\mathrm{Zn}$ (concentration) & 12 & 12 & 0 \\
\hline $\mathrm{Zn}$ (loading) & 12 & 12 & 0 \\
\hline $\operatorname{Gross} \alpha$ & 250 & 250 & 0 \\
\hline Strontium - 90 & 12 & 12 & $O^{(a)}$ \\
\hline Flow & 365 & 365 & 0 \\
\hline Chlorine (rosidual) & 250 & 250 & 0 \\
\hline Fecal Coliform & 12 & 39 & 0 \\
\hline Total Collform & 12 & 34 & 1 \\
\hline Tritiun & 250 & 250 & 0 \\
\hline $\begin{array}{l}1,1,1 \text {-trich1oro- } \\
\text { othane }\end{array}$ & 6 & 6 & 0 \\
\hline Total & 2781 & 2888 & 6 \\
\hline
\end{tabular}

(a) Contractor laboratory has reported only nine months of data. No exceedances were observed in the data received. 


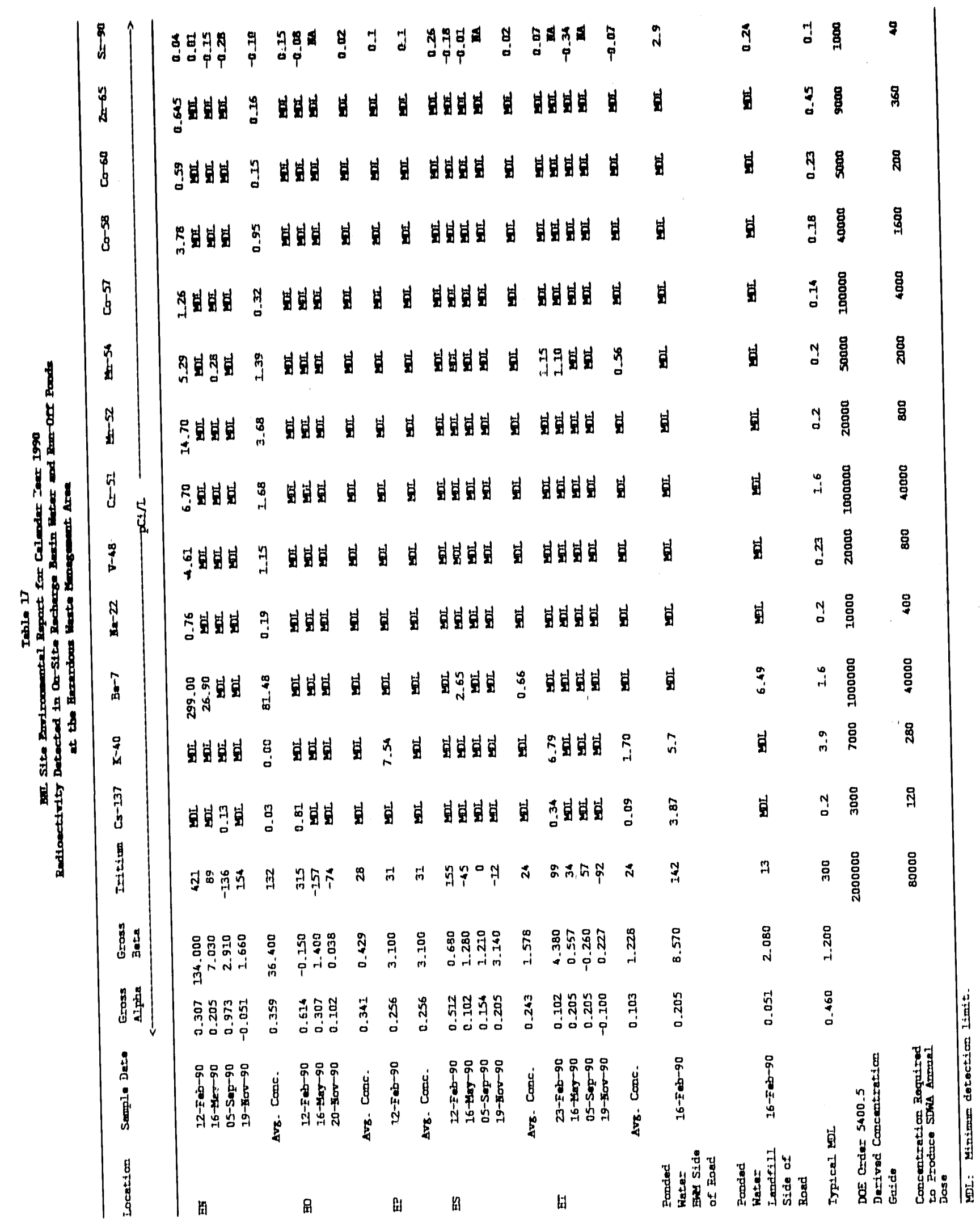




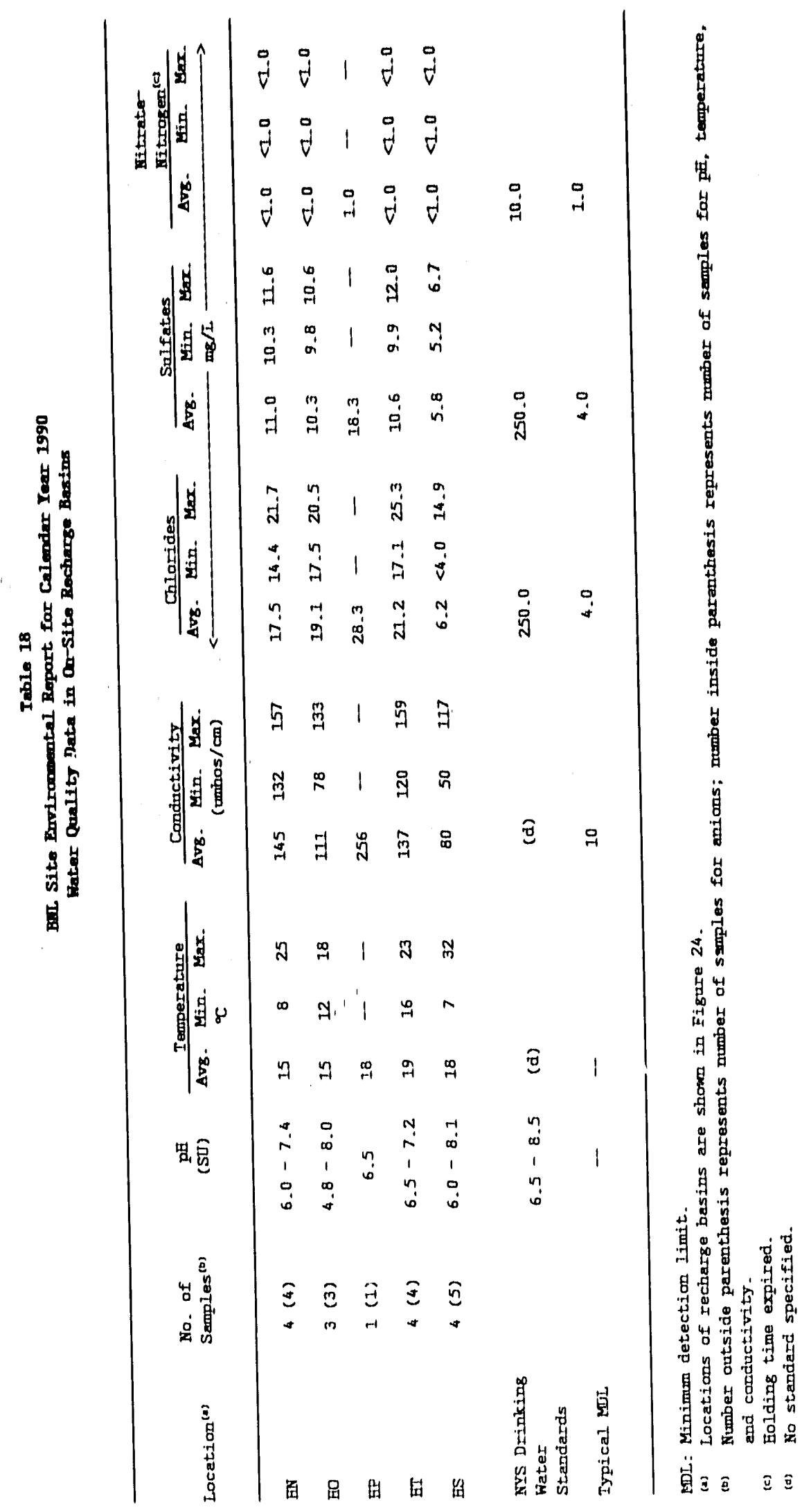


Table 19

BNL Site Environmental Report for Calendar Year 1990 Average Metals Data in On-Site Recharge Basins

\begin{tabular}{|c|c|c|c|c|c|c|}
\hline \multirow[b]{2}{*}{ Parameter } & \multicolumn{5}{|c|}{ Location (a) } & \multirow{2}{*}{$\begin{array}{l}\text { NYS } \\
\text { Drinking } \\
\text { Water } \\
\text { Stds }\end{array}$} \\
\hline & $\begin{array}{l}\mathrm{HN} \\
<-\ldots\end{array}$ & $\begin{array}{c}\text { HO } \\
\ldots . . .\end{array}$ & $\begin{array}{c}\mathrm{HP} \\
--\mathrm{mg} / \mathrm{L}-\end{array}$ & $\begin{array}{c}\text { HT } \\
\ldots\end{array}$ & $\begin{array}{c}\text { HS } \\
\cdots \cdot-\cdot>\end{array}$ & \\
\hline No. of Samples ${ }^{(b)}$ & $4(2)$ & $3(1)$ & $1(0)$ & $4(2)$ & $4(2)$ & \\
\hline $\mathrm{Ag}$ & $<0.025$ & $<0.025$ & $<0.025$ & $<0,025$ & $<0.025$ & 0.05 \\
\hline $\mathrm{Cd}$ & 0.0001 & $<0.0005$ & $<0.0005$ & $<0.0005$ & $<0.0005$ & 0.01 \\
\hline $\mathrm{Cr}$ & $<0.005$ & $<0.005$ & $<0.005$ & $<0.005$ & $<0.005$ & 0.05 \\
\hline $\mathrm{Cu}$ & 0.04 & $<0.05$ & $<0.05$ & 0.03 & $<0.05$ & 1.0 \\
\hline $\mathrm{Fe}$ & 0.58 & 0.38 & 0.24 & 0.14 & 0.40 & 0.3 \\
\hline $\mathrm{Hg}$ & $<0.0002$ & $<0.0002$ & NA & $<0.0002$ & $<0.0002$ & 0.002 \\
\hline Mn & 0.05 & $<0.05$ & $<0.05$ & $<0.05$ & 0.04 & 0.3 \\
\hline $\mathrm{Na}$ & 12.9 & 11.6 & 18.7 & 11.5 & 7.2 & (c) \\
\hline $\mathrm{Pb}$ & 0.002 & $<0.005$ & $<0.005$ & 0.001 & 0.001 & 0.05 \\
\hline $\mathrm{Zn}$ & 0.04 & 0.01 & $<0.02$ & 0.02 & 0.02 & 5.0 \\
\hline
\end{tabular}

NA: Not analyzed.

(a) Locations of recharge basins are shown in Figure 24.

(b) Number inside parenthesis represents number of samples analyzed for $\mathrm{Hg}$; number outside parenthesis represents number of samples analyzed for all other parameters.

(c) No standard specified. 
Table 19A

BNL Site Environmental Report for Calendar Year 1990

Chlorocarbon Data in On-site Recharge Basins

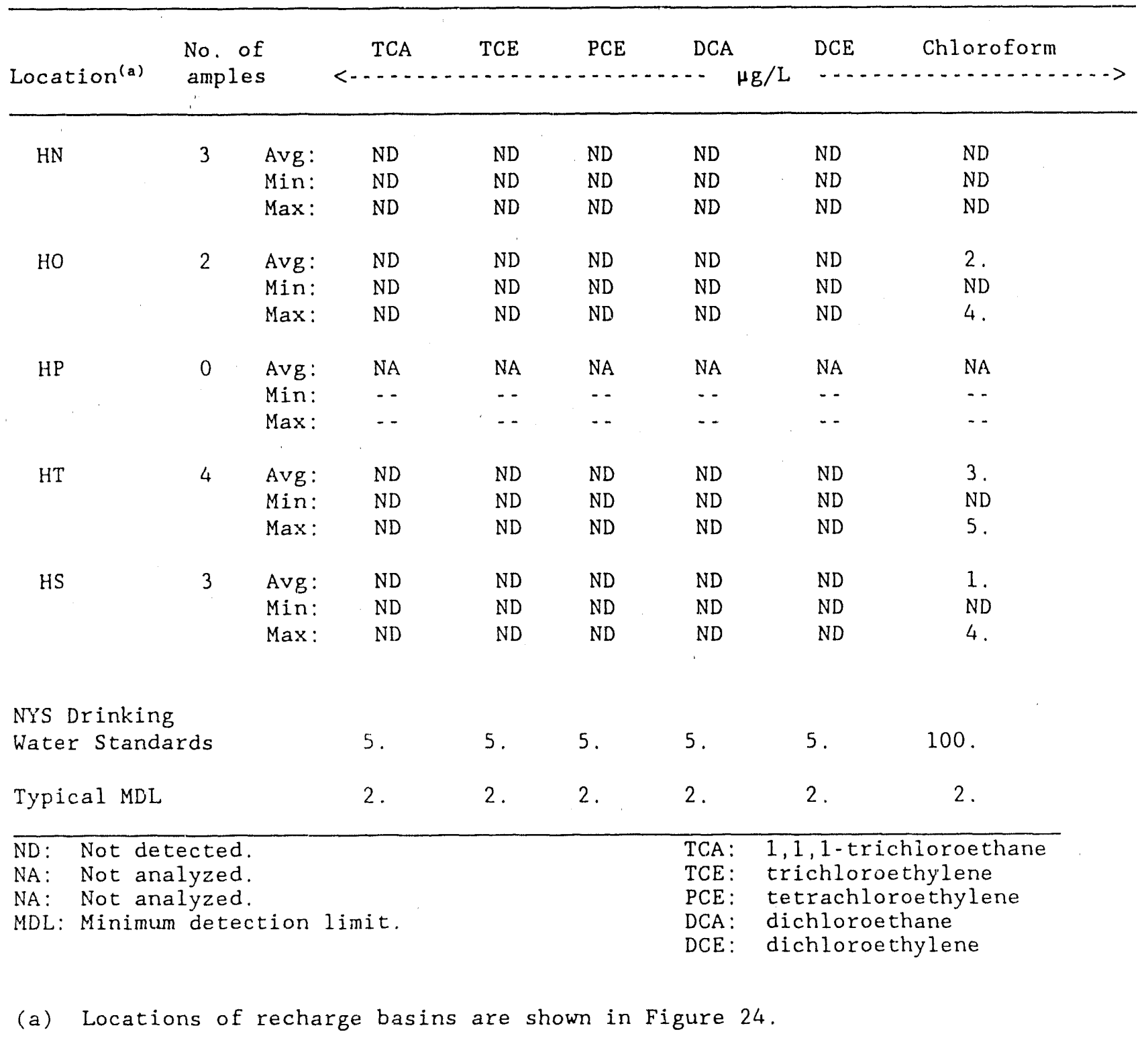


Table 19B

BNL Site Environmental Report for Calendar Year 1990 BTX Data in On-site Recharge Basins

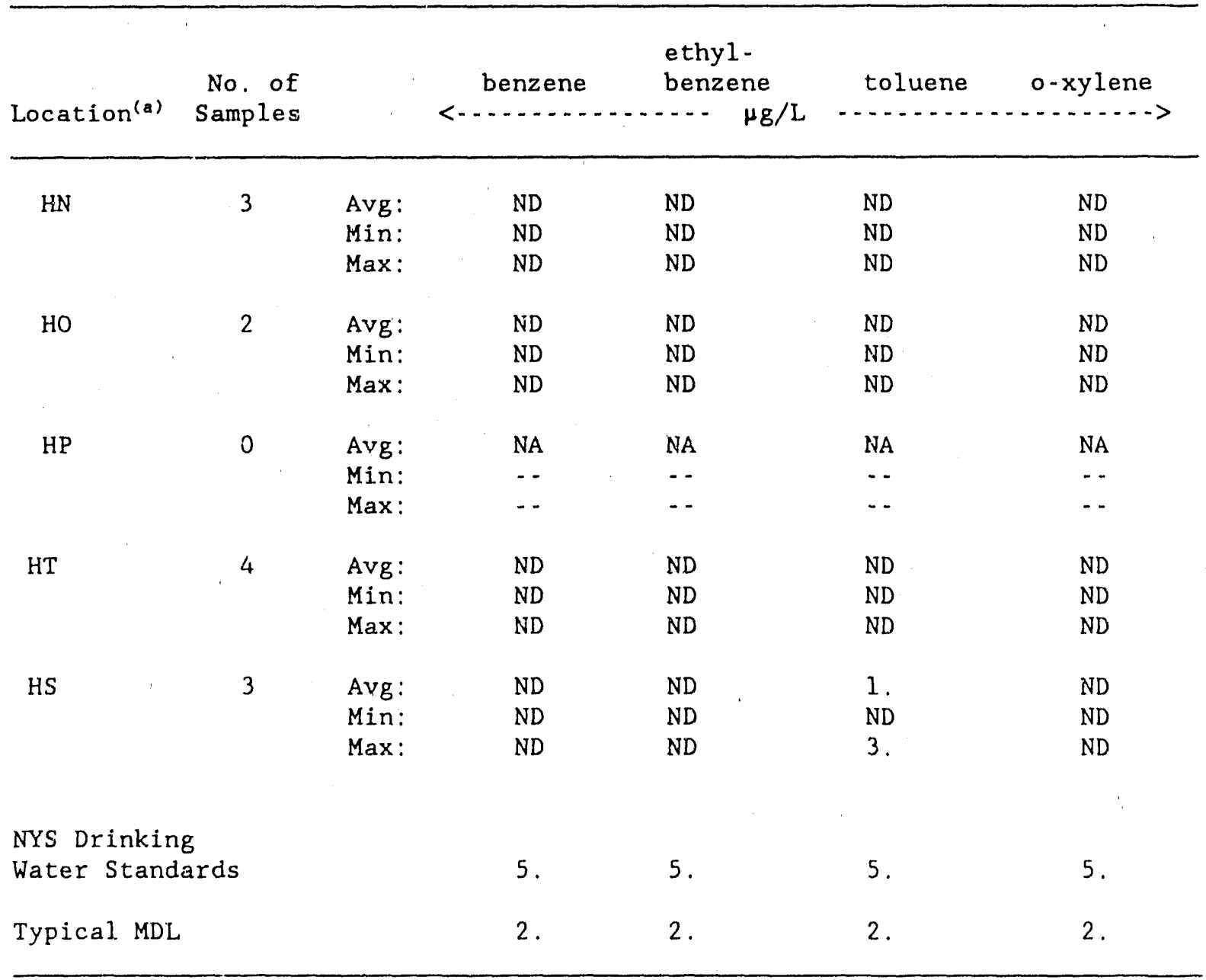

ND: Not detected.

NA: Not analyzed.

MDL: Minimum detection limit.

(a) Locations of recharge basins are shown in Figure 24. 


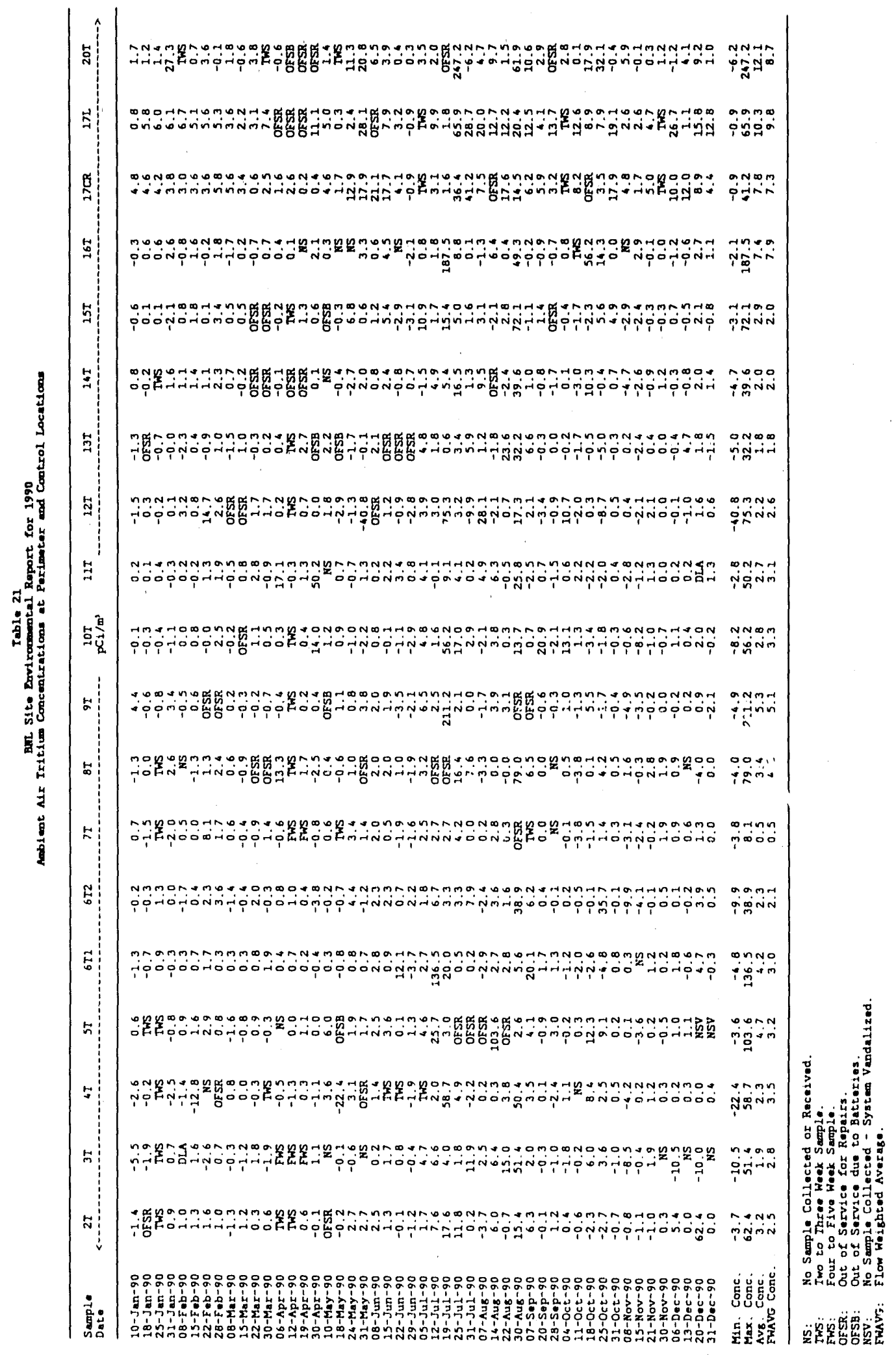


Table 22

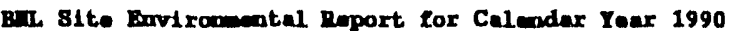

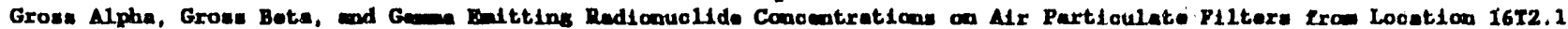

\begin{tabular}{|c|c|c|c|c|c|c|c|c|c|c|c|c|c|}
\hline \multirow[b]{2}{*}{ Month } & \multicolumn{4}{|c|}{ Gross Alpha } & \multicolumn{3}{|c|}{ Gross Beta } & \multicolumn{3}{|c|}{$B_{e}-7$} & \multicolumn{3}{|c|}{$I-126$} \\
\hline & & Avg. & Min. & Max. & Avg. & Min. & $\underset{\mathrm{pC} 1 / \mathrm{m}^{\prime}}{\operatorname{Max}}$ & Av8. & Min. & Max. & AvB. & Min. & Max. \\
\hline $\begin{array}{l}\text { January } \\
\text { Fobruary }\end{array}$ & $\begin{array}{l}462 \\
392\end{array}$ & $\begin{array}{l}0.0018 \\
0.0016\end{array}$ & $\begin{array}{l}0.0008 \\
0.0003\end{array}$ & $\begin{array}{l}0.0028 \\
0.0031\end{array}$ & $\begin{array}{l}0.0480 \\
0.0426\end{array}$ & $\begin{array}{l}0.0312 \\
0.0322\end{array}$ & $\begin{array}{l}0.0636 \\
0.0491\end{array}$ & $\begin{array}{l}0.0000 \\
0.0000\end{array}$ & $\begin{array}{l}0.0000 \\
0.0000\end{array}$ & $\begin{array}{l}0.0000 \\
0.0000\end{array}$ & $\begin{array}{l}0.0348 \\
0.00 \cap n\end{array}$ & $\begin{array}{l}0.1480 \\
0.0000\end{array}$ & $\begin{array}{l}0.1480 \\
0.0000\end{array}$ \\
\hline March & 422 & 0.0014 & -0.0003 & 0.0026 & 0.0426 & 0.0349 & 0.0502 & 0.1227 & 0.4730 & 0.4730 & 0.0000 & 0.0000 & 0.0000 \\
\hline April & 438 & 0.0019 & 0.0005 & 0.0036 & 0.0347 & 0.0262 & 0.0432 & 0.0867 & 0.2420 & 0.2420 & 0.0000 & 0.0000 & 0.0000 \\
\hline May & 442 & 0.0006 & 0.0000 & 0.0013 & 0.0214 & 0.0164 & 0.0307 & 0.2609 & 0.4100 & 0.5670 & 0.0000 & 0.0000 & 0.0000 \\
\hline June & 316 & 0.0015 & 0.0008 & 0.0025 & 0.0343 & 0.0307 & 0.0401 & 0.2198 & 0.2330 & 0.4230 & 0.0000 & 0.0000 & 0.0000 \\
\hline July & 464 & 0.0010 & 0.0003 & 0.0020 & 0.0357 & 0.0293 & 0.0451 & 0.1336 & 0.2620 & 0.3570 & 0.0000 & 0.0000 & 0.0000 \\
\hline August & 436 & 0.0540 & 0.0008 & 0.2280 & 0.0326 & 0.0252 & 0.0389 & 0.0869 & 0.3750 & 0.3750 & 0.0000 & 0.0000 & 0.0000 \\
\hline September & 415 & 0.0013 & 0.0007 & 0.0025 & 0.0299 & 0.0243 & 0.0400 & 0.0751 & 0.2720 & 0.2720 & 0.0000 & 0,0000 & 0.0000 \\
\hline October & 472 & 0.0019 & 0.0012 & 0.0023 & 0.0347 & 0.0266 & 0.0412 & 0.2963 & 0.2070 & 0.7090 & 0.0000 & 0.0000 & 0.0000 \\
\hline November & 403 & 0.0024 & 0.0009 & 0.0052 & 0.0456 & 0.0424 & 0.0494 & 0.1298 & 0.0713 & 0.2170 & 0.0000 & 0,0000 & 0.0000 \\
\hline Deomber & 427 & 0.0020 & 0.0013 & 0.0028 & 0.0396 & 0.0309 & 0.0492 & 0.1354 & 0.1570 & 0.2820 & 0.0000 & 0.0000 & 0.0000 \\
\hline $\begin{array}{l}\text { Annual } \\
\text { Average }\end{array}$ & 424 & 0.0061 & -0.0003 & 0.2280 & 0.0368 & 0.0164 & 0.0636 & 0.1288 & 0.0000 & 0.7090 & 0.0032 & 0.0000 & 0.1480 \\
\hline Typical MDL & & 0.002 & & & 0.006 & & & 0.213 & & & 0.064 & & \\
\hline $\begin{array}{l}\text { DOE Order } \\
5400.5 \text { DAC }\end{array}$ & & NA & & & NA & & & 40,000 & & & 300 & & \\
\hline
\end{tabular}

ML: Minimum detection limit.

DAC: Derived alr concentration.

NA: Not applicable. 
Table 23

BNL Site Environmental Report for Calendar Year 1990

Gross Alpha, Gross Beta, and Gamma Emitting Radionuclide Concentrations on Alr Particulate Filters from Location $11 \mathrm{T2}, 1$

\begin{tabular}{|c|c|c|c|c|c|c|c|c|c|c|}
\hline \multirow[b]{2}{*}{ Month } & \multirow[b]{2}{*}{$\begin{array}{c}\text { Flow } \\
\mathrm{m}^{3}\end{array}$} & \multicolumn{3}{|c|}{ Gross Alpha } & \multicolumn{3}{|c|}{ Gross Beta } & \multicolumn{3}{|c|}{$\mathrm{Be}-7$} \\
\hline & & $\begin{array}{l}\text { Avg. } \\
<-.\end{array}$ & $\begin{array}{c}\text { Min. } \\
. . . . . .\end{array}$ & $\begin{array}{c}\text { Max. } \\
\ldots \ldots\end{array}$ & Avg. & $\begin{array}{l}\mathrm{MIn} \\
\mathrm{pCi} / \mathrm{m}^{3}\end{array}$ & $\begin{array}{r}\text { Max. } \\
\quad-\end{array}$ & Avg. & Min. & Max. \\
\hline January & 472 & 0.0017 & 0.0012 & 0.0020 & 0.0342 & 0.0220 & 0.0418 & 0.0000 & 0.0000 & 0.0000 \\
\hline February & 404 & 0.0012 & 0.0000 & 0.0026 & 0.0406 & 0.0365 & 0.0495 & 0.0564 & 0.1980 & 0.1980 \\
\hline March & 429 & 0.0009 & -0.0002 & 0.0025 & 0.0418 & 0.0344 & 0.0488 & 0.2484 & 0.2500 & 0.7110 \\
\hline April & 445 & 0.0023 & 0.0000 & 0.0037 & 0.0336 & 0.0294 & 0.0426 & 0.0539 & 0.2790 & 0.2790 \\
\hline May & 447 & 0.0013 & 0.0005 & 0.0021 & 0.0254 & 0.0140 & 0.0339 & 0.1291 & 0.1900 & 0.2950 \\
\hline June & 420 & 0.0012 & 0.0008 & 0.0018 & 0.0340 & 0.0283 & 0.0395 & 0.1292 & 0.4700 & 0.4700 \\
\hline July & 467 & 0.0014 & 0.0000 & 0.0026 & 0.0363 & 0.0335 & 0.0397 & 0.0784 & 0.1740 & 0.2210 \\
\hline August & 440 & 0.0017 & 0.0011 & 0.0024 & 0.0326 & 0.0275 & 0.0356 & 0.0000 & 0.0000 & 0.0000 \\
\hline September & 420 & 0.0011 & 0.0004 & 0.0018 & 0.0277 & 0.0218 & 0.0362 & 0.1093 & 0.1110 & 0.2160 \\
\hline October & 481 & 0.0015 & 0.0005 & 0.0023 & 0.0378 & 0.0323 & 0.0467 & 0.1169 & 0.2900 & 0.3020 \\
\hline November & 430 & 0.0019 & -0.0003 & 0.0032 & 0.0471 & 0.0362 & 0.0592 & 0.0281 & 0.1200 & 0.1200 \\
\hline December & 445 & 0.0020 & 0.0012 & 0.0033 & 0.0398 & 0.0287 & 0.0545 & 0.0000 & 0.0000 & 0.0000 \\
\hline \multicolumn{11}{|l|}{ Average } \\
\hline Typical MD & IDL & 0.002 & & & 0.006 & & & 0.204 & & \\
\hline \multicolumn{11}{|l|}{ DOE Order } \\
\hline $5400.5 \mathrm{DAC}$ & & $\mathrm{NA}$ & & & NA & & & 40,000 & & \\
\hline
\end{tabular}

MDL: Minimum detection limit.

DAC: Derived air concentration.

NA: Not applicable. 
Table 24

BNL site Environmental Report for Calendar Yeax 1990

Gross Alpha, Gross Beta, and Gamma Emitting Radionuclide Concentrations on Air Particulate Filters from Location $6 \mathrm{~T} 2.8$

\begin{tabular}{|c|c|c|c|c|c|c|c|c|c|c|}
\hline \multirow[b]{2}{*}{ Month } & \multirow[b]{2}{*}{$\begin{array}{c}\text { Flow } \\
\mathrm{m}^{3}\end{array}$} & \multicolumn{3}{|c|}{ Gross Alpha } & \multicolumn{3}{|c|}{ Gross Beta } & \multicolumn{3}{|c|}{$\mathrm{Be}-7$} \\
\hline & & $\begin{array}{r}\text { Avg. } \\
<-\cdots .\end{array}$ & Min. & $\overline{\operatorname{Max} .}$ & Avg. & $\underset{\mathrm{pC1} / \mathrm{m}^{3}}{\mathrm{Min}}$ & Max. & Avg. & Min. & $\begin{array}{c}\text { Max. } \\
\ldots . .>\end{array}$ \\
\hline January & 458 & 0.0018 & 0.0003 & 0.0031 & 0.0390 & 0.0328 & 0.0456 & 0.0000 & 0.0000 & 0.0000 \\
\hline February & 388 & 0.0014 & -0.0013 & 0.0042 & 0.0384 & 0.0314 & 0.0447 & 0.1603 & 0.1830 & 0.3110 \\
\hline March & 411 & 0.0029 & 0.0016 & 0.0040 & 0.0405 & 0.0340 & 0.0446 & 0.2043 & 0.1680 & 0.2290 \\
\hline Apri1 & 415 & 0.0022 & 0.0003 & 0.0038 & 0.0393 & 0.0286 & 0.0500 & 0.0454 & 0.1280 & 0.1280 \\
\hline May & 414 & 0.0017 & 0.0014 & 0.0021 & 0.0297 & 0.0274 & 0.0325 & 0.0481 & 0.2170 & 0.2170 \\
\hline June & 381 & 0.0015 & 0.0011 & 0.0020 & 0.0361 & 0.0322 & 0.0438 & 0.0845 & 0.1260 & 0.1960 \\
\hline July & 385 & 0.0013 & -0.0010 & 0.0046 & 0.0453 & 0.0357 & 0.0633 & 0.0000 & 0.0000 & 0.0000 \\
\hline August & 395 & 0.0023 & 0.0007 & 0.0038 & 0.0360 & 0.0326 & 0.0416 & 0.1021 & 0.1550 & 0.2780 \\
\hline September & 373 & 0.0020 & 0.0012 & 0.0027 & 0.0421 & 0.0326 & 0.0533 & 0.1266 & 0.2830 & 0.2830 \\
\hline October & 460 & 0.0024 & 0.0015 & 0.0033 & 0.0442 & 0.0357 & 0.0546 & 0.0939 & 0.2010 & 0.2310 \\
\hline November & 424 & 0.0031 & 0.0015 & 0.0041 & 0.0454 & 0.0385 & 0.0522 & 0.2246 & 0.1930 & 0.3720 \\
\hline December & 436 & 0.0029 & 0.0007 & 0.0057 & 0.0402 & 0.0289 & 0.0489 & 0.2142 & 0.1610 & 0.3630 \\
\hline $\begin{array}{l}\text { Annual } \\
\text { Average }\end{array}$ & 412 & 0.0022 & -0.0013 & 0.0057 & 0.0397 & 0.0274 & 0.0633 & 0.1086 & 0.0000 & 0.3720 \\
\hline Typical MDL & & 0.002 & & & 0.006 & & & 0.219 & & \\
\hline DOE Order & & & & & & & & & & \\
\hline $5400.5 \mathrm{DAC}$ & & NA & & & $\mathrm{NA}$ & & & 40,000 & & \\
\hline
\end{tabular}

MDL: Minimum detection limit.

DAC: Derived air concentration.

INA: Not applicable. 
Table 25

BNL S1te Environmental Report for Calendar Year 1990

Gross Alpha, Gross Beta, and Gamma Emltting Radionuclide Concentrations on Alr Particulate F1.1ters from Location $4 \mathrm{~T} 2.4$

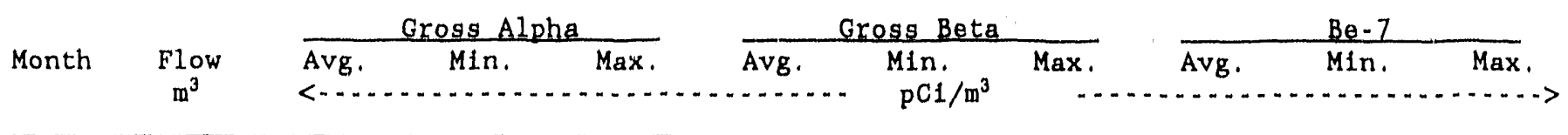

\begin{tabular}{|c|c|c|c|c|c|c|c|c|c|c|}
\hline January & 460 & 0.0014 & -0.0003 & 0.0040 & 0.0317 & 0.0208 & 0.0408 & 0.0000 & 0.0000 & 0.0000 \\
\hline February & 391 & 0.0014 & 0.0003 & 0.0024 & 0.0424 & 0.0375 & 0.0478 & 0.0505 & 0.2350 & 0.2350 \\
\hline March & 419 & 0.0013 & -0.0003 & 0.0030 & 0.0418 & 0.0360 & 0.0471 & 0.1459 & 0.1620 & 0.4020 \\
\hline April & 434 & 0.0018 & 0.0000 & 0.0034 & 0.0344 & 0.0270 & 0.0453 & 0.0231 & 0.1020 & 0.1020 \\
\hline May & 433 & 0,0014 & 0.0005 & 0.0023 & 0.0267 & 0.0228 & 0.0319 & 0.0000 & 0.0000 & 0.0000 \\
\hline June & 407 & 0.0014 & 0.0008 & 0.0023 & 0.0335 & 0.0301 & 0.0363 & 0.0000 & 0.0000 & 0.0000 \\
\hline July & 452 & 0.0017 & -0.0012 & 0.0033 & 0.0364 & 0.0319 & 0.0407 & 0.0000 & 0.0000 & 0.0000 \\
\hline August & 426 & 0.0010 & 0.0003 & 0.0020 & 0.0463 & 0.0297 & 0.0837 & 0.0000 & 0.0000 & 0.0000 \\
\hline September & 407 & 0.0026 & 0.0018 & 0.0031 & 0.0291. & 0.0252 & 0.0330 & 0.0651 & 0.1450 & 0.1450 \\
\hline October & 466 & 0.0014 & 0.0008 & 0.0021 & 0.0378 & 0.0331 & 0.0434 & 0.0000 & 0.0000 & 0.0000 \\
\hline November & 422 & 0.0021 & 0.0015 & 0.0029 & 0.0454 & 0.0368 & 0.0534 & 0.0000 & 0.0000 & 0.0000 \\
\hline December & 418 & 0.0017 & 0.0015 & 0.0020 & 0.0392 & 0.0286 & 0.0511 & 0.0000 & 0.0000 & 0.0000 \\
\hline $\begin{array}{l}\text { Annual } \\
\text { Average }\end{array}$ & 428 & 0.0016 & -0.0012 & 0.0040 & 0.0370 & 0.0208 & 0.0837 & 0.0229 & 0.0000 & 0.4020 \\
\hline \multicolumn{2}{|c|}{ Typical MDL } & \multicolumn{3}{|l|}{0.002} & \multicolumn{3}{|l|}{0.006} & \multicolumn{3}{|l|}{0.211} \\
\hline \multicolumn{11}{|l|}{ DOE Order } \\
\hline $5400.5 \mathrm{DAC}$ & & NA & & & NA & & & 40,000 & & \\
\hline
\end{tabular}

MDL: Minimum detection limit.

DAC: Derived air concentration.

NA: Not applicable. 
Table 26

BNL S1te Environmental Report for Calendax Year 1990

Gross Alpha, Gross Beta, and Gamma Emitting Radionuclide Concentrations on Alr Particulate Filters from Location $\mathbf{S} 6$

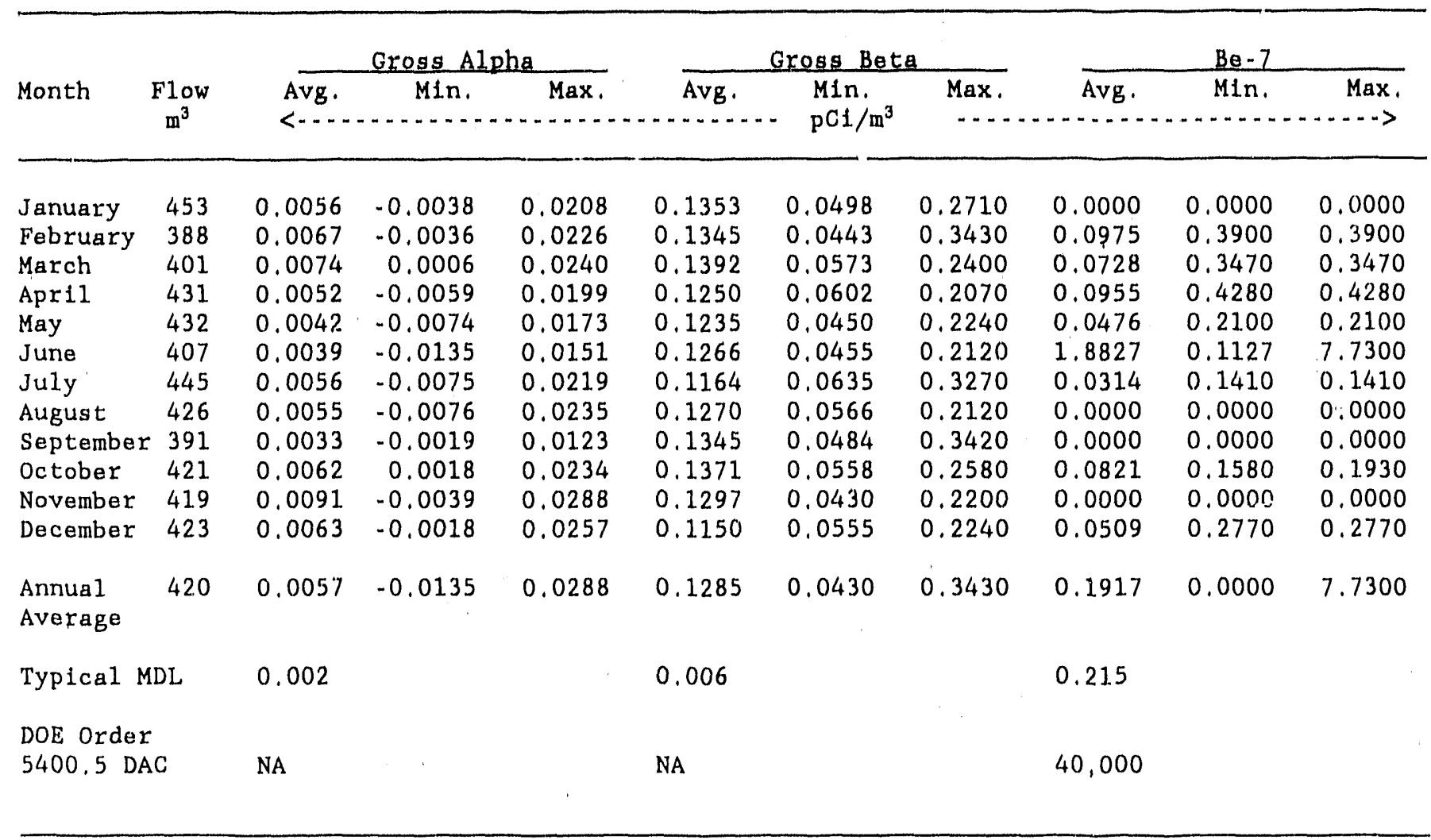

MDL: Minimum detection limit.

DAC: Derived air concentration.

NA: Not applicable. 
Table 27

BNL Site Environmental Report for Calendar Year 1990

Charcoal Filter Data for Station 16T2.1

\begin{tabular}{|c|c|c|c|c|}
\hline Month & $\begin{array}{l}\text { Flow } \\
\mathrm{m}^{3}\end{array}$ & $\begin{array}{c}\mathrm{Cs} \cdot 137 \\
<\ldots \ldots \ldots\end{array}$ & $\begin{array}{c}\text { Radionu } \\
\mathrm{K}-40 \\
\mathrm{pCl} / \mathrm{m}^{3}\end{array}$ & $R a-226$ \\
\hline January & 462 & 0.0037 & 0.536 & ND \\
\hline February & 392 & 0.0065 & 0.524 & 0.065 \\
\hline March & 422 & ND & 0.766 & ND \\
\hline Apri1 & 438 & 0.0039 & 0.469 & 0.045 \\
\hline May & 442 & 0.0052 & 0.508 & 0.049 \\
\hline June & 316 & ND & 0.672 & ND \\
\hline July & 464 & 0.0021 & 0.471 & 0.062 \\
\hline August & 436 & 0.0037 & 0.473 & 0.055 \\
\hline September & 415 & 0.0094 & 0.542 & ND \\
\hline October & 472 & ND & 0.536 & ND \\
\hline November & 20 & 0.1210 & 11.300 & ND \\
\hline December & 427 & 0.0084 & 0.518 & ND \\
\hline $\begin{array}{l}\text { Annual } \\
\text { Average }\end{array}$ & 392 & 0.0044 & 0.589 & 0.025 \\
\hline Typical MDL & & 0.0033 & 0.069 & 0.007 \\
\hline \multicolumn{5}{|l|}{ DOE Order } \\
\hline $5400.5 \mathrm{DAC}$ & & 400 & 900 & 1.0 \\
\hline
\end{tabular}

ND: Not detected.

MDL: Minimum detection limit.

DAC: Derived air concentration.

Note: November sample collected for only one week. Results indicate activity in charcoal filter. 
Table 28

BNL S1te Environmental Report for Oalendar Year 1990 Oharcoal F11ter Data for Station 11T2.1.

\begin{tabular}{|c|c|c|c|c|c|}
\hline \multirow[b]{2}{*}{ Month } & \multirow{2}{*}{$\underset{\mathrm{m}^{3}}{\mathrm{Tl}}$} & \multirow{2}{*}{$\begin{array}{c}\mathrm{Cs}-137 \\
<\ldots \ldots\end{array}$} & \multicolumn{2}{|c|}{ Rad1onuc11do } & \multirow[b]{2}{*}{$\mathrm{Be}-7$} \\
\hline & & & $\mathrm{K}-40$ & $R a-226$ & \\
\hline January & 473 & ND & 0.435 & 0.1 .82 & ND \\
\hline Fobruary & 404 & 0.0069 & 0.536 & ND & ND \\
\hline March & 429 & 0.0043 & 0.525 & ND & ND \\
\hline Apr11 & 1445 & ND & 2.490 & ND & ND \\
\hline May & 447 & ND & 0.422 & ND & ND \\
\hline June & 420 & 0.0038 & 0.602 & ND & ND \\
\hline July & 467 & 0.0052 & 0.535 & ND & ND \\
\hline August & 440 & ND & 0.553 & ND & ND \\
\hline September & 420 & 0.0122 & 0.702 & ND & ND \\
\hline October & 481 & 0.0048 & 0.487 & ND & ND \\
\hline November & 430 & 0.0082 & 0.416 & ND & ND \\
\hline December & 445 & 0.0041 & 0.457 & ND & 0.0482 \\
\hline Annua 1 & 442 & 0.0040 & 0.679 & 0.016 & 0.004 \\
\hline Average & & & & & \\
\hline Typical MDL & & 0.0029 & 0.061 & 0.007 & 0.021 \\
\hline DOE Order & & & & & \\
\hline 5400.5 DAC & & 400 & 900 & 1.0 & 40,000 \\
\hline
\end{tabular}

ND: Not detected.

MDL: Minimum detection 1 init.

DAC: Derived air concentration. 
Tuble 29

BNL S1ta Lnvironmental Report for Oalandar Yoar 1990 Oharooul F11ter Data for station 6 12,8

\begin{tabular}{|c|c|c|c|c|c|}
\hline \multirow{3}{*}{ Month } & \multirow{3}{*}{$\begin{array}{l}\text { F'low } \\
\mathrm{mi}^{3}\end{array}$} & \multirow{3}{*}{$\begin{array}{l}\mathrm{Cg} \cdot 1.37 \\
<\ldots \ldots\end{array}$} & \multicolumn{2}{|c|}{ Radionuolide } & \multirow{3}{*}{$\mathrm{Th}^{\prime}-228$} \\
\hline & & & $k \cdot 40$ & $\quad R a-22 G$ & \\
\hline & & & $\ldots \ldots$ & $\mathrm{pCl} / \mathrm{ml}^{3}$ & \\
\hline January & 4.58 & 0,0038 & 0.411 & ND & ND \\
\hline Fobruary & 388 & ND & 0.688 & 0.012 & ND \\
\hline March & 411 & 0.01 .59 & 0,583 & ND & ND \\
\hline Apr:11. & 41.5 & 0.0043 & $0.61 \%$ & ND & 0.0049 \\
\hline May & 408 & 0.0044 & 0.591 & ND & ND \\
\hline June & 381 & 0.0046 & 0.514 & ND & ND \\
\hline July & 385 & 0.0040 & 0.540 & ND & ND \\
\hline Augurt & 395 & 0.0047 & 0.578 & ND & ND \\
\hline September: & 373 & 0.0045 & 0.545 & ND & ND \\
\hline October & 460 & 0.0039 & 0.489 & ND & ND \\
\hline November & 424 & 0.0052 & 0.585 & ND & ND \\
\hline December & 436 & 0,0052 & 0.568 & ND & ND \\
\hline $\begin{array}{l}\text { Annual } \\
\text { Average }\end{array}$ & 411 & 0.0051 & 0.557 & 0.001 & 0.0004 \\
\hline Typica1 MDL & & 0.0032 & 0.066 & 0.007 & 0.006 \\
\hline \multicolumn{2}{|l|}{ DOE Order } & & & & \\
\hline $5400.5 \mathrm{DAC}$ & & 400 & 900 & 1.0 & 0.04 \\
\hline
\end{tabular}

ND: Not dotected.

MDL: Mininum detection 1imit.

DAC: Derlved alr concentration. 
Tuble 30

BNL 81te Unvironimenta1 Report for Oulendar Year 1990 Oharcoal F11tor Data For Station 4'2,4

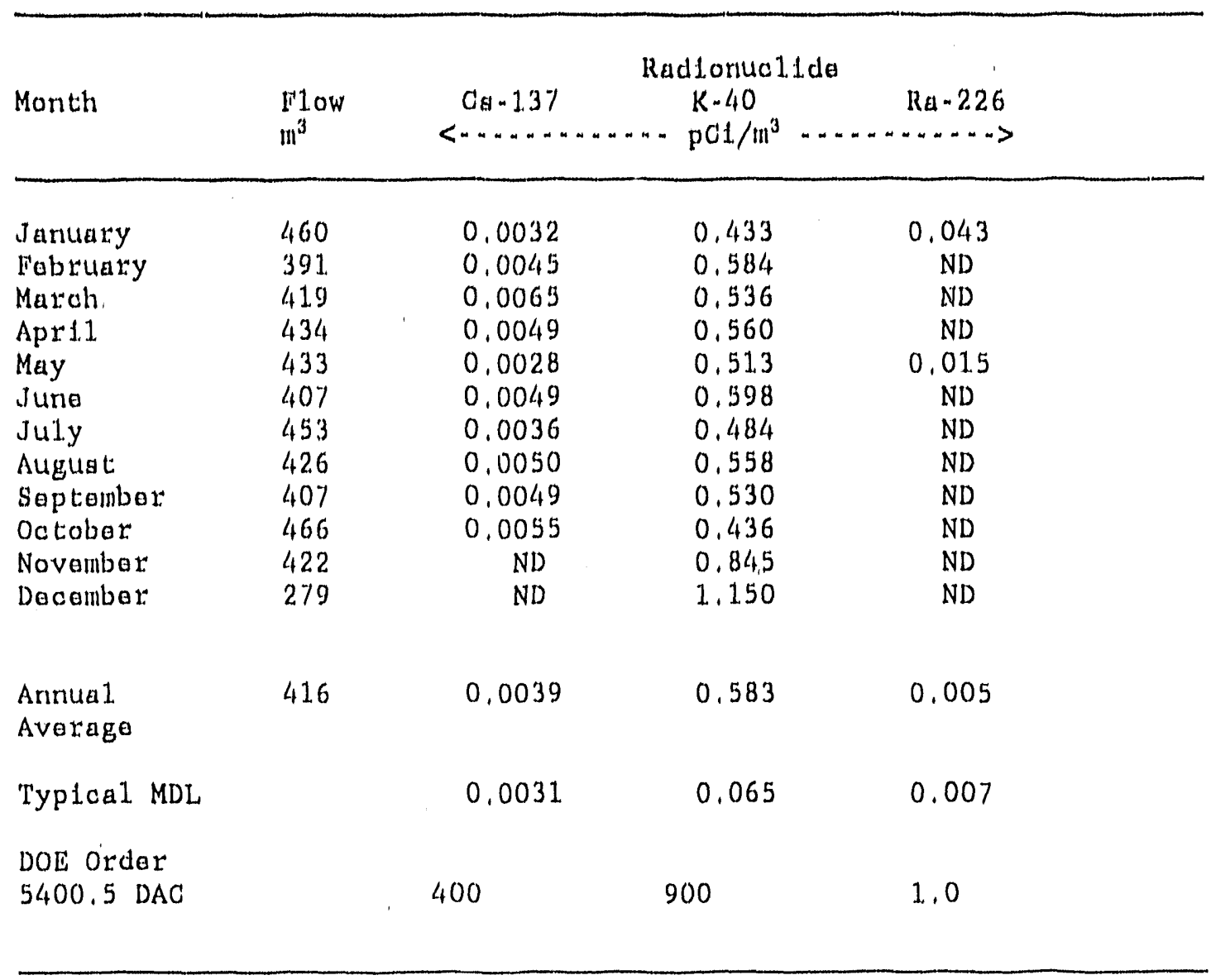

ND: Not detectod.

MDL: Minfinum detection 1 imf.t.

DAC: Derived air concentration. 
Table 31

BNL S1te Invironmental Report for Calundar Year 1990 Oharcoal F11ter Data for Station $\$ 6$

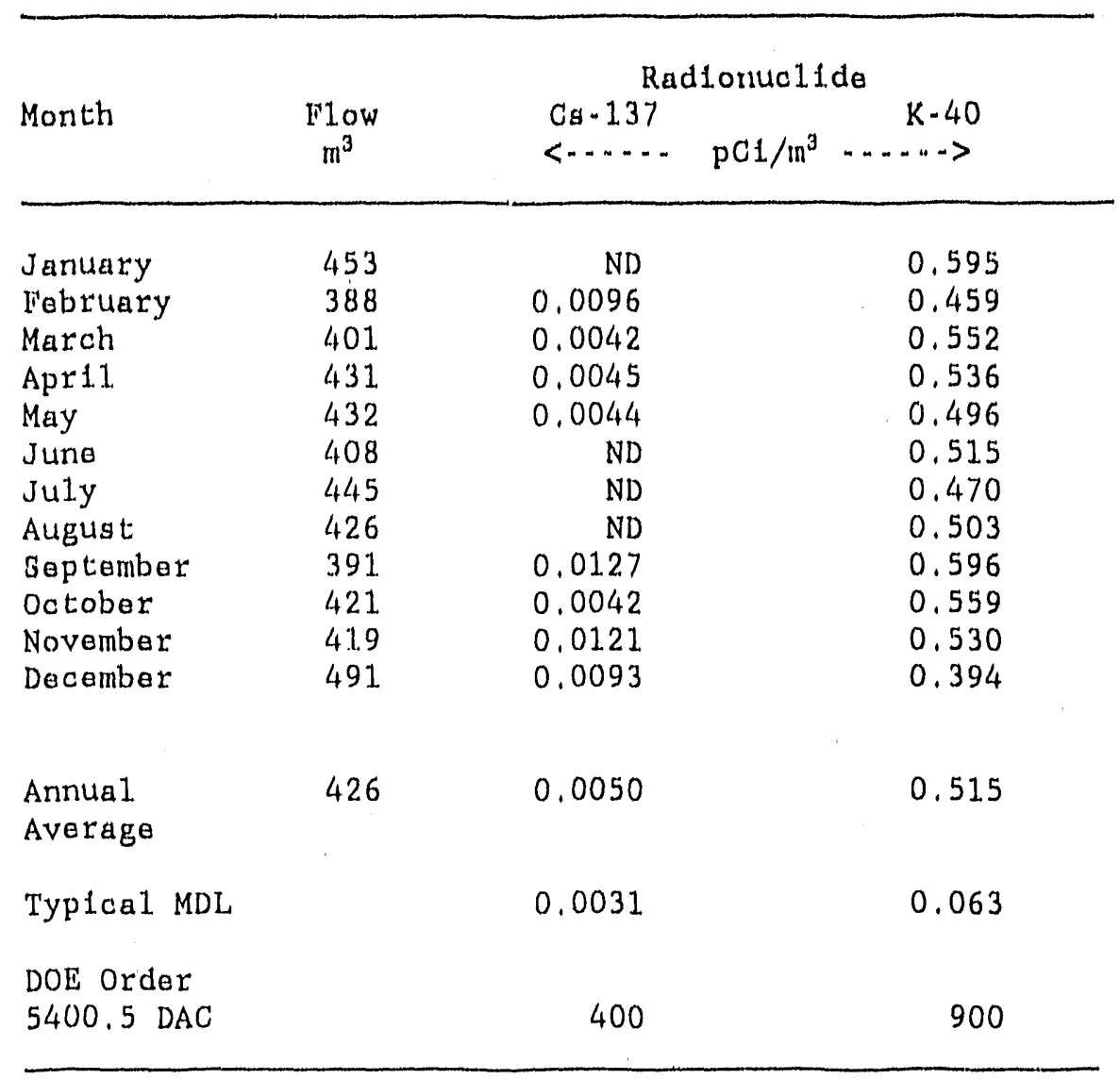

ND: Not detected.

MDL: Minimum detection $11 \mathrm{mLt}$.

DAC: Derived air concentration. 
Tablo 32

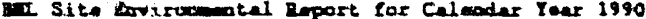

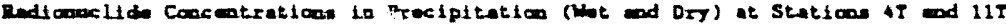

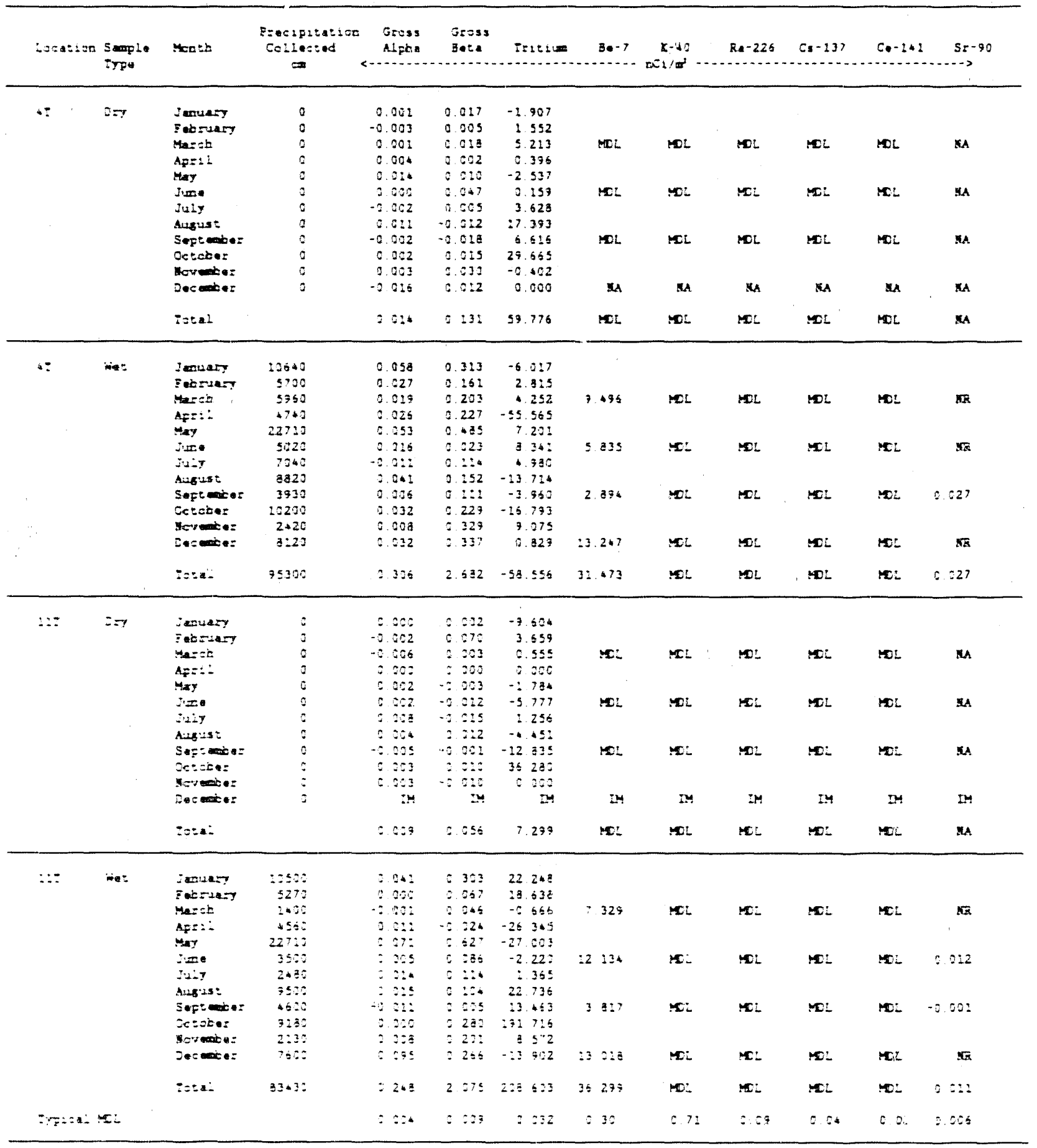

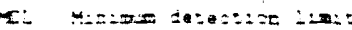

if $5:=$ aFFi:

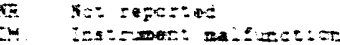

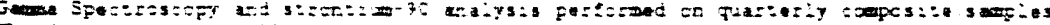

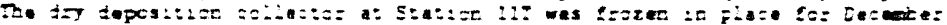

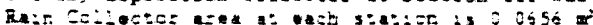


Table 33

BNL Site Environmental Report for Calendar Year 1990

Radionuclide Concentrations in

Vegetation and Soll in the Vicinity of BNL

\begin{tabular}{|c|c|c|c|c|c|c|c|}
\hline Location & Matrix & $\begin{array}{l}\text { Sample } \\
\text { Date }\end{array}$ & $\begin{array}{r}\mathrm{Be}-7 \\
<\ldots-\cdots\end{array}$ & Cs -137 & $\begin{array}{l}\mathrm{K}-40 \\
\mathrm{pCi} / \mathrm{g}\end{array}$ & $\begin{array}{c}\mathrm{Ra}-226 \\
-\end{array}$ & $\begin{array}{l}\text { Th }-228 \\
\ldots .-->>\end{array}$ \\
\hline $\begin{array}{l}\text { Yaphank } \\
\text { Honor } \\
\text { Farm }\end{array}$ & Soil & $07 / 20 / 90$ & 0.12 & 0.11 & 5.27 & 0.44 & 0.58 \\
\hline $\begin{array}{l}\text { NYS Game } \\
\text { Farm } \\
\text { (Ridge) }\end{array}$ & Soil & $07 / 20 / 90$ & ND & 0.52 & 1.83 & 0.12 & 0.18 \\
\hline $\begin{array}{l}\text { Berenzey } \\
\text { Farm }\end{array}$ & Soi.1 & $07 / 20 / 90$ & ND & 0.10 & 4.72 & 0.47 & 0.62 \\
\hline $\begin{array}{l}\text { Yaphank } \\
\text { Honor } \\
\text { Farm }\end{array}$ & Grass & $07 / 20 / 90$ & 0.89 & ND & 2.79 & ND & ND \\
\hline $\begin{array}{l}\text { NYS Game } \\
\text { Farm } \\
\text { (Ridge) }\end{array}$ & Grass & $07 / 20 / 90$ & ND & 0.36 & 13.90 & ND & ND \\
\hline $\begin{array}{l}\text { Berenzey } \\
\text { Farm }\end{array}$ & Grass & $07 / 20 / 90$ & 0.48 & ND & 3.78 & ND & ND \\
\hline Typical MDL & & & 0.07 & 0.01 & 0.18 & 0.03 & 0.02 \\
\hline
\end{tabular}

ND: Not detected. Radionuclide Concentration less than the system MDL. MDL: Minimum detection limit. 
Table 34

BII Site Enviromontal Report for Calendar Year 1990

Gross Npha, Gross Beta, and Iritiu Concentrations in Peconle River and Carmans River

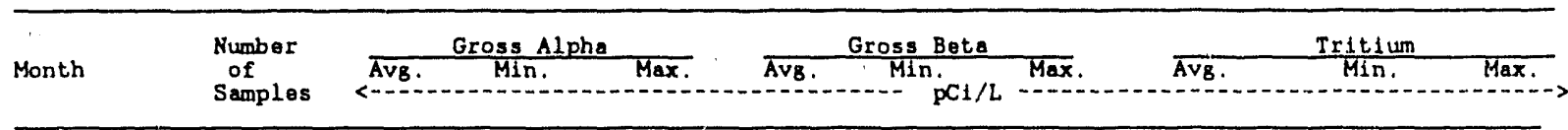

Sample Location Station EM

$\begin{array}{lll}\text { January } & 14 & 0.27 \\ \text { February } & 11 & 0.1 \\ \text { March } & 13 & 0.1 \\ \text { April } & 13 & 0.4 \\ \text { May } & 13 & 0.2 \\ \text { June } & 12 & 0.2 \\ \text { July } & 12 & -0.0 \\ \text { August } & 13 & -0.1 \\ \text { September } & 11 & 0.5 \\ \text { October } & 14 & 0.6 \\ \text { November } & 11 & 0.2 \\ \text { December } & 12 & 0.2 \\ \text { Annual } & 149 & 0.26\end{array}$

$\begin{array}{rr}0.27 & -0.77 \\ 0.18 & -1.79 \\ 0.18 & -0.77 \\ 0.43 & -1.28 \\ 0.26 & -1.02 \\ 0.21 & -1.54 \\ -0.02 & -1.02 \\ -0.10 & -2.56 \\ 0.53 & -0.77 \\ 0.62 & -0.51 \\ 0.28 & -1.28 \\ 0.21 & -0.77 \\ 0.26 & -2.56\end{array}$

2.05
2.30
2.05
1.54
2.82
2.56
1.54
1.02
2.05
1.54
1.79
1.02
2.82

$\begin{array}{rr}3.76 & -4.16 \\ 2.44 & -1.70 \\ 5.71 & 1.32 \\ 4.07 & -1.32 \\ 5.28 & 0.94 \\ 4.14 & -3.78 \\ 5.21 & 1.70 \\ 6.09 & 2.27 \\ 4.96 & 1.13 \\ 5.61 & -0.19 \\ 5.42 & 2.83 \\ 6.89 & 1.70 \\ 4.98 & -4.16\end{array}$
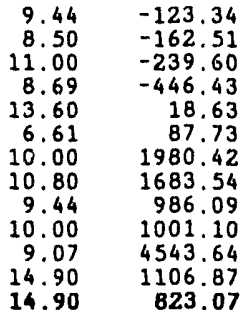

$-546.00$

$-1760.00 \quad 438.00$

-1760.00
-1880.00

$\begin{array}{rr}-1880.00 & 747.00 \\ -628.00 & 732.00\end{array}$

$-628.00 \quad 732.00$

$\begin{array}{rr}-904.00 & 653.00 \\ -159.00 & 9110.00\end{array}$

$\begin{array}{rr}-159.00 & 9110.00 \\ 434.00 \quad 4340.00\end{array}$

$\begin{array}{rr}434.00 & 4340.00 \\ -282.00 \quad 2690.00\end{array}$

$-564.00 \quad 3120.00$
-310.00

$3110.00 \quad 6750.00$

$\begin{array}{rr}-341.00 & 5170.00 \\ -1880.00 & 9110.00\end{array}$

Sample Location Station 80

$\begin{array}{lrlll}\text { January } & 10 & 0.21 & -2.05 & 1.5 \\ \text { February } & 6 & 0.47 & -0.26 & 1.5 \\ \text { March } & 10 & 0.13 & -1.28 & 1.2 \\ \text { Apri1 } & 12 & 0.51 & -1.54 & 1.5 \\ \text { May } & 10 & 0.66 & -1.54 & 2.3 \\ \text { June } & 11 & 0.23 & -1.28 & 1.7 \\ \text { July } & 12 & 0.06 & -1.79 & 1.2 \\ \text { August } & 12 & 0.17 & -1.02 & 1.5 \\ \text { September } & 10 & 0.49 & -0.77 & 1.7 \\ \text { October } & 13 & 0.47 & -1.28 & 1.2 \\ \text { November } & 11 & 0.30 & -0.51 & 1.02 \\ \text { December } & 12 & 0.21 & -0.77 & 1.5 \\ \quad \text { Annual } & 129 & 0.32 & -2.05 & \mathbf{2 . 3}\end{array}$

$\begin{array}{lr}3.40 & -2.27 \\ 2.55 & -1.70 \\ 4.37 & -2.08 \\ 2.96 & -0.94 \\ 4.70 & -0.38 \\ 4.76 & -0.38 \\ 4.08 & 0.00 \\ 4.69 & 1.51 \\ 4.12 & 1.13 \\ 7.63 & 3.97 \\ 4.10 & 1.13 \\ 6.54 & -0.19 \\ 4.63 & -2.27\end{array}$

5.67

8.88
10.80

10.80

11.10

7.18
9.25

9.25
8.69

7.18
13.20

13.20
6.42

6.42
21.70

21.70
21.70

823.07

Sample Location St fileIgr RA - Peconic River off Site

\begin{tabular}{|c|c|c|c|c|c|c|c|c|c|c|}
\hline $\begin{array}{l}\text { February } \\
\text { September } \\
\text { November } \\
\text { Annual }\end{array}$ & $\begin{array}{l}1 \\
1 \\
1 \\
3\end{array}$ & $\begin{array}{l}0.15 \\
0.00 \\
0.26 \\
0.14\end{array}$ & 0.00 & 0.26 & $\begin{array}{l}1.33 \\
2.12 \\
1.47 \\
1.64\end{array}$ & 1.33 & 2.12 & $\begin{array}{l}128.00 \\
882.00 \\
443.00 \\
484.00\end{array}$ & 128.00 & 882.00 \\
\hline \multicolumn{11}{|c|}{ Sample Location Station BB - PGconlc River off Site } \\
\hline $\begin{array}{l}\text { February } \\
\text { September } \\
\text { Hovember } \\
\text { Annual }\end{array}$ & $\begin{array}{l}1 \\
1 \\
1 \\
3\end{array}$ & $\begin{array}{l}0.00 \\
0.00 \\
0.05 \\
0.02\end{array}$ & 0.00 & 0.05 & $\begin{array}{l}0.76 \\
1.93 \\
1.89 \\
1.53\end{array}$ & 0.76 & 1.93 & $\begin{array}{r}70.90 \\
882.00 \\
252.00 \\
402.00\end{array}$ & 11.00 & 882.00 \\
\hline \multicolumn{11}{|c|}{ Sample locating Station BC - Peconic River off Site } \\
\hline $\begin{array}{l}\text { February } \\
\text { September } \\
\text { November } \\
\text { Annual }\end{array}$ & $\begin{array}{l}1 \\
1 \\
1 \\
3\end{array}$ & $\begin{array}{r}0.10 \\
0.15 \\
-0.10 \\
0.05\end{array}$ & -0.10 & 0.15 & $\begin{array}{l}1.32 \\
1.17 \\
2.23 \\
1.57\end{array}$ & 1.17 & 2.23 & $\begin{array}{r}-100.00 \\
765.00 \\
295.00 \\
319.00\end{array}$ & -102.00 & 765.00 \\
\hline \multicolumn{11}{|c|}{ Sample Location Station BR - Peconic River off Site } \\
\hline $\begin{array}{l}\text { February } \\
\text { September } \\
\text { November } \\
\text { Annual }\end{array}$ & $\begin{array}{l}1 \\
1 \\
1 \\
3\end{array}$ & $\begin{array}{l}0.31 \\
0.26 \\
0.21 \\
0.26\end{array}$ & 0.21 & 0.31 & $\begin{array}{l}0.57 \\
1.66 \\
3.40 \\
1.88\end{array}$ & 0.57 & 3.40 & $\begin{array}{r}22.20 \\
473.00 \\
351.00 \\
282.00\end{array}$ & 22.00 & 473.00 \\
\hline \multicolumn{11}{|c|}{ Sample Location Station HH - Carmans River } \\
\hline $\begin{array}{c}\text { February } \\
\text { September } \\
\text { November } \\
\text { Anmual }\end{array}$ & $\begin{array}{l}1 \\
1 \\
1 \\
3\end{array}$ & $\begin{array}{l}0.00 \\
0.15 \\
0.05 \\
0.07\end{array}$ & 0.00 & 0.15 & $\begin{array}{l}0.15 \\
1.02 \\
1.93 \\
1.03\end{array}$ & 0.15 & 1.93 & $\begin{array}{r}66.50 \\
409.00 \\
-130.00 \\
116.00\end{array}$ & -129.00 & 409.00 \\
\hline $\begin{array}{l}\text { Typical MDL } \\
\text { for EM and } \mathrm{BQ}\end{array}$ & 2.3 & & & 6 & & & & 1000 & & \\
\hline $\begin{array}{l}\text { Typical MDL } \\
\text { All Others }\end{array}$ & 0.46 & & & 1.2 & & & & 300 & & \\
\hline
\end{tabular}

MDL: Minimum detection limit. 


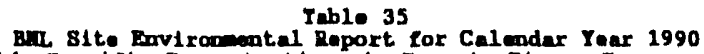
Huclide Spocific Concentrations in Pecoulc Rtver, Carmens River

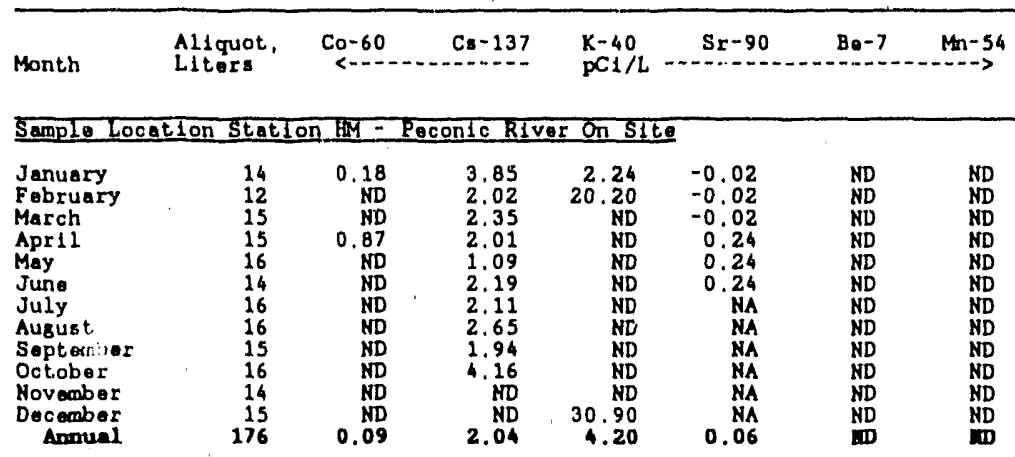

Sample Location Station 80 - Peconic River on Site

\begin{tabular}{lrrrrrrr}
\hline June & 9 & ND & 1.64 & ND & NA & ND & ND \\
July & 16 & ND & 2.13 & ND & NA & ND & ND \\
Ausust & 16 & ND & 3.59 & ND & NA & ND & ND \\
Septtembor & 15 & ND & 2.17 & ND & NA & ND & ND \\
October & 17 & ND & 2.32 & ND & NA & ND & ND \\
November & 15 & ND & 0.38 & ND & NA & ND & ND \\
December & 15 & 0.29 & ND & ND & NA & ND & WD \\
Amual & 101 & 0.04 & 1.78 & 0.70 & MA & MD &
\end{tabular}

Sample Location Station HA - Peconlc Rlver Off Slte

$\begin{array}{rlllllll}1 \text { st Qtr. } & 12 & \text { ND } & 0.56 & 6.20 & 0.28 & \text { ND } & \text { ND } \\ \text { 3rd Qtr: } & 12 & \text { ND } & \text { ND } & \text { ND } & 0.24 & \text { ND } & \text { ND } \\ \text { Ammuoi } & 24 & \text { ND } & 0.28 & 3.10 & 0.26 & \text { WD } & \text { ID }\end{array}$

Sample Location Station BB - Peconte River Off S1te

$\begin{array}{cccccccc}\text { 1st Qtr. } & 12 & \text { ND } & 0.87 & \text { ND } & 0.27 & \text { ND } & \text { ND } \\ \text { 3rd Qtr. } & 12 & \text { ND } & \text { ND } & \text { ND } & -0.03 & \text { ND } & \text { ND } \\ \text { 4th Qtr. } & 12 & \text { ND } & 0.92 & \text { ND } & \text { NA } & \text { ND } & \text { ND } \\ \text { Amuai } & 36 & \text { ND } & 0.60 & \text { W } & 0.12 & \text { m } & \text { m }\end{array}$

Sample Location Station HC - Pecontc RIver Off Sito

$\begin{array}{rlllllll}\text { 1st Qtr. } & 12 & \text { ND } & \text { ND } & \text { ND } & 0.24 & \text { ND } & \text { ND } \\ \text { 3rd Qtr. } & 12 & \text { ND } & \text { ND } & \text { ND } & 0.30 & \text { ND } & \text { ND } \\ \text { 4th Qtr. } & 12 & \text { ND } & \text { ND } & \text { ND } & \text { NA } & \text { ND } & \text { ND } \\ \text { Anauai } & 36 & \text { ID } & \text { ND } & \text { ID } & \mathbf{0 . 2 7} & \text { ND }\end{array}$

Sample Location Station HR - Peconic River off Site

$\begin{array}{rrrrrrrr}\text { 1st Qtr. } & 12 & \text { ND } & 0.51 & 2.62 & 0.54 & 2.65 & 0.14 \\ \text { 3rd Qtr. } & 12 & \text { ND } & \text { ND } & \text { ND } & 0.54 & \text { ND } & \text { ND } \\ \text { 4th Qtr. } & 12 & \text { ND } & \text { ND } & \text { ND } & \text { NA } & \text { ND } & \text { ND } \\ \text { Amual } & 36 & \text { W } & 0.17 & 0.87 & 0.54 & 0.88 & 0.05\end{array}$

Somple Location Station HH - Carmans River

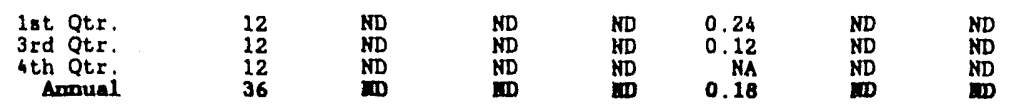

Sample Location - Peconlc River at BML North Gate

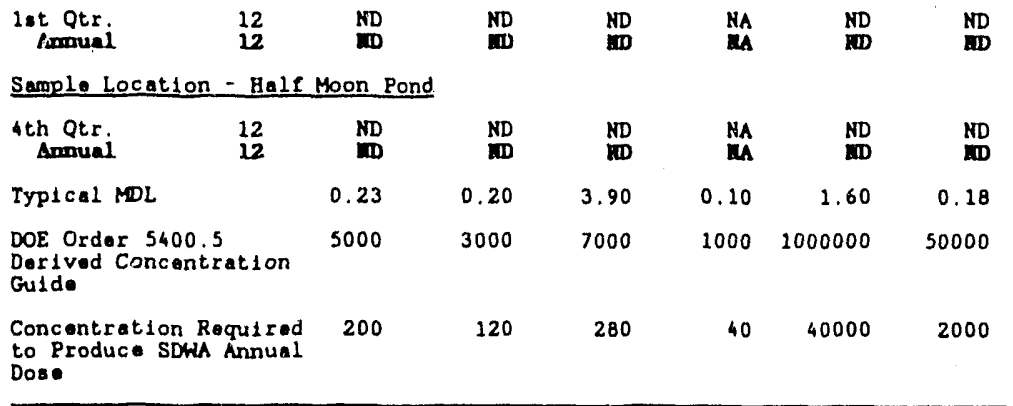

HA: Not analyzod

ND: Not detocted.

MLL: Minimion detection limlt 


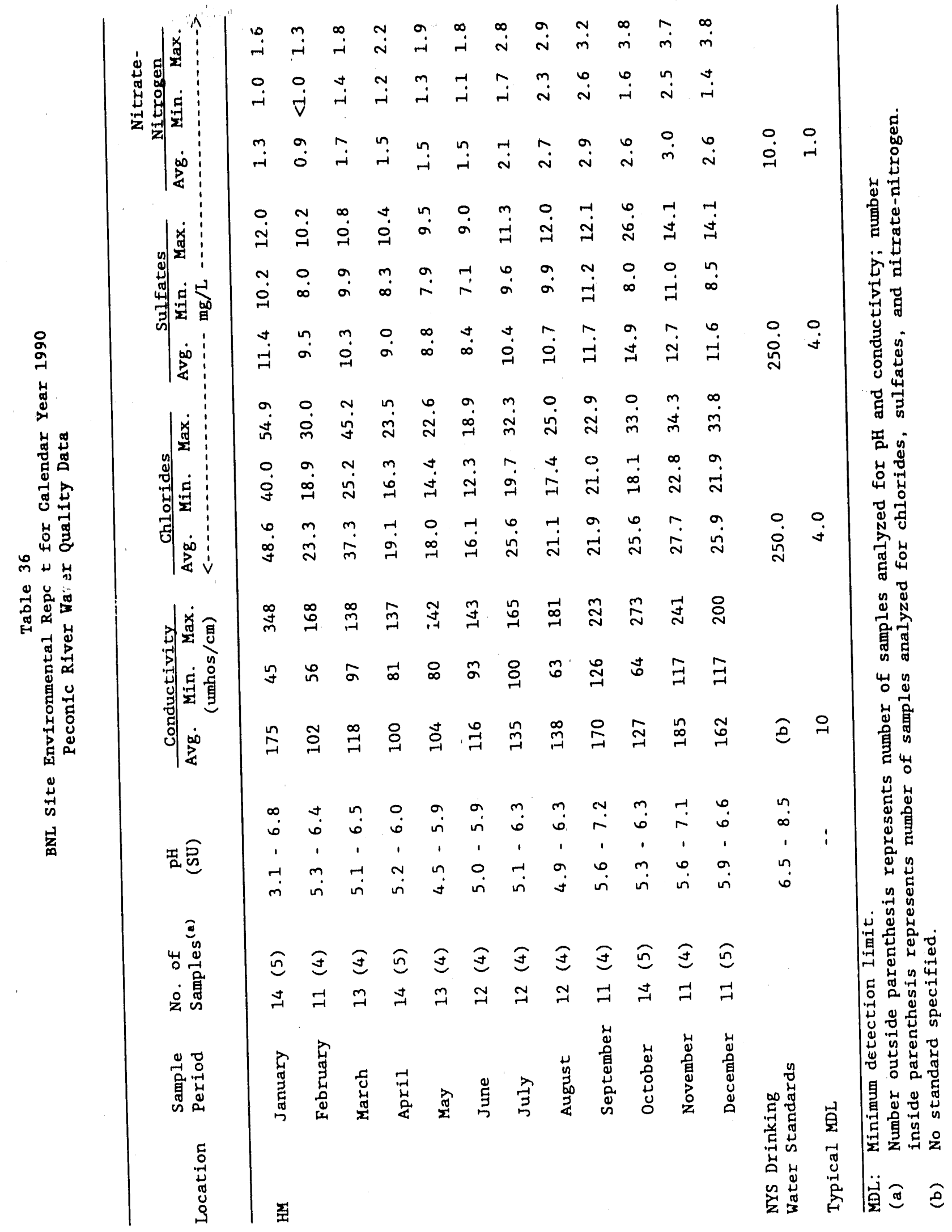




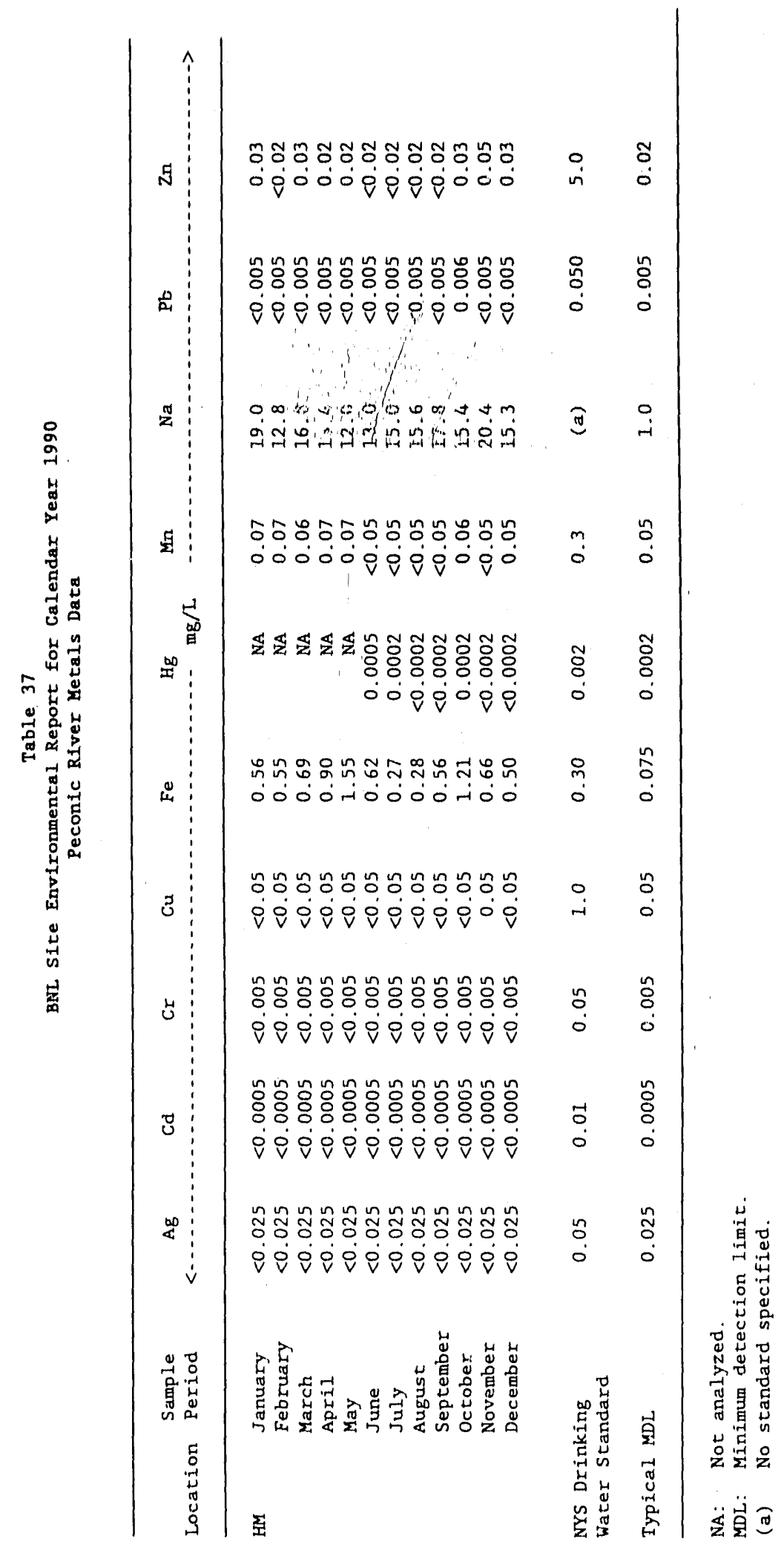




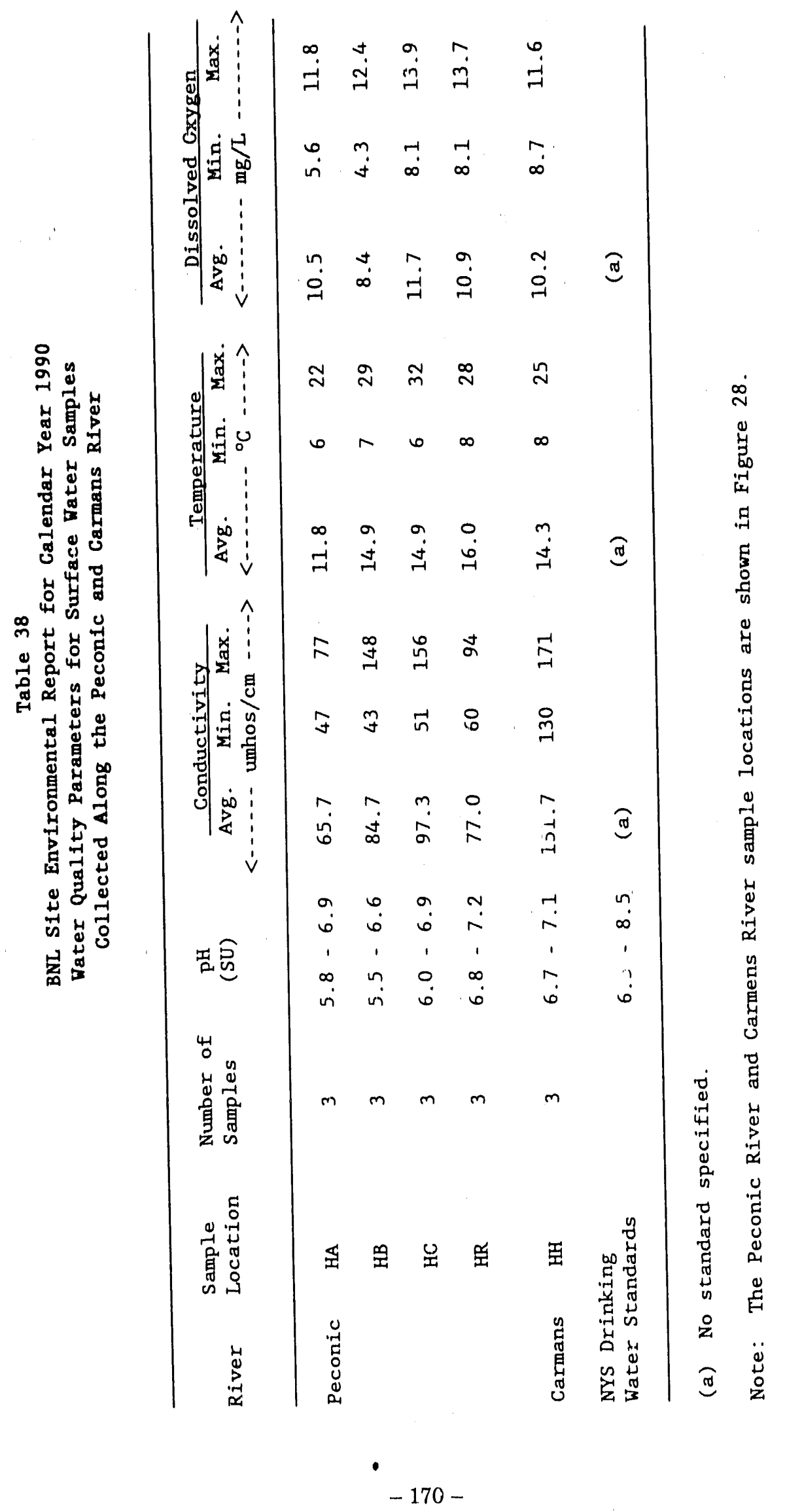




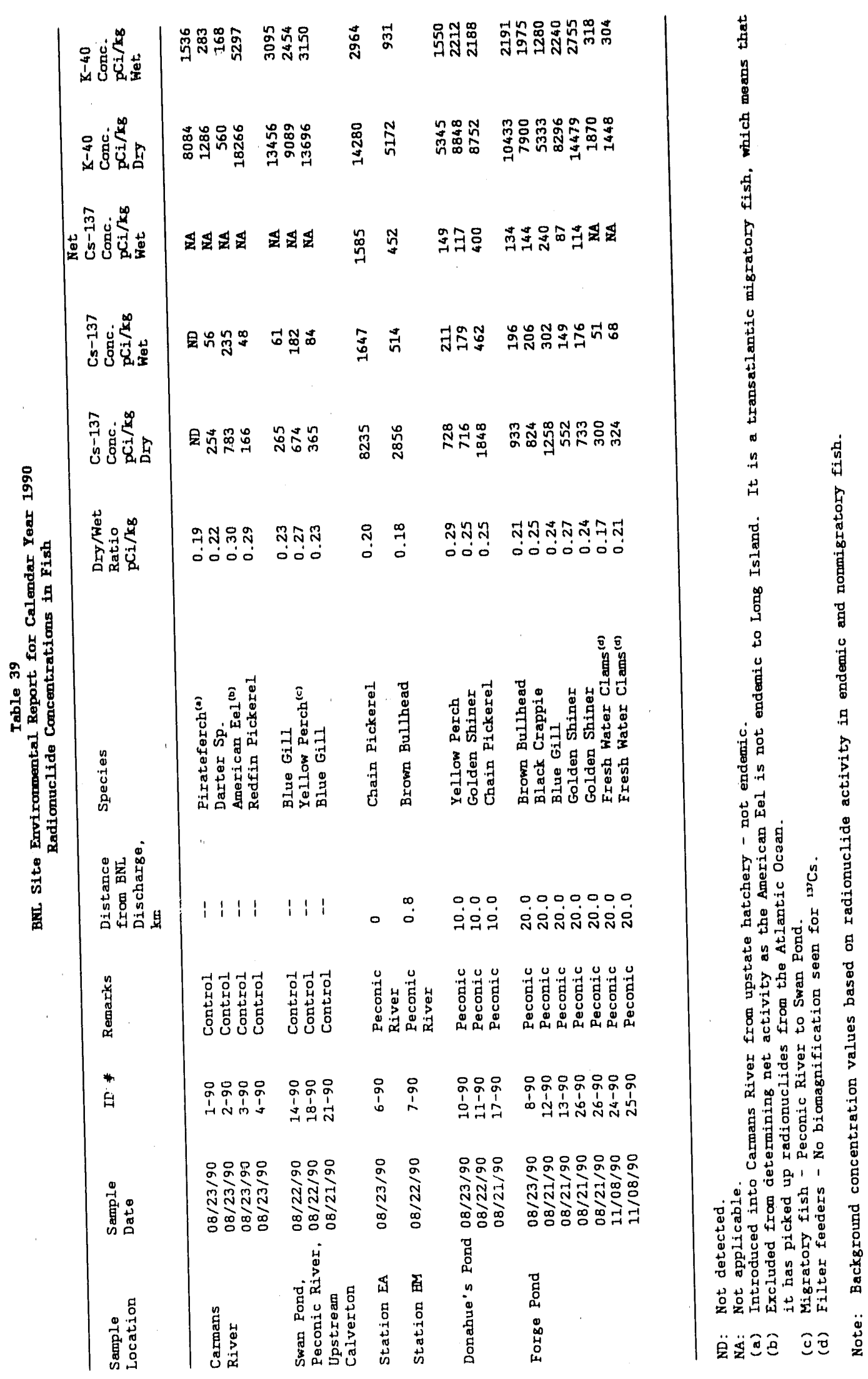


Table 40

Bul sito Kurifronmental Report for Calandar Year 1990

On-a1te Potable and Cooling Water Radionuolide Comomitration Data

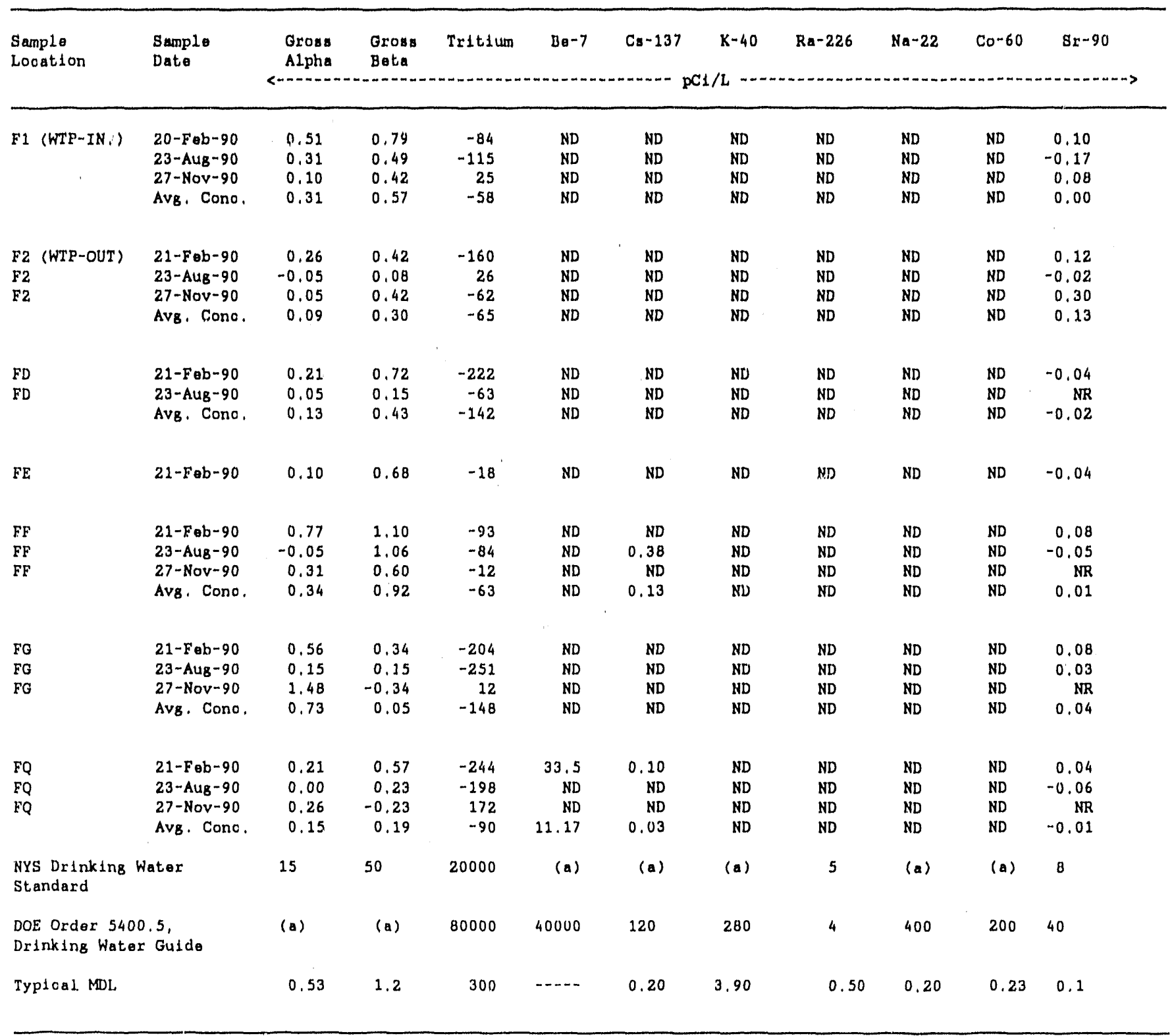

WTP-IN: Water Treatment Plant influent.

WTP-OUT: Water Treatment Plant effluent.

ND: Not detected.

NR: Result not reportad from off-site Contractar Laboratory

MDL: Minimum detection limit

(a) No standard specified.

Note: DOE Order 5400.5 drinking water guide concentrations obtained by dividing DCGs by 25 . 
Table 41

BRL b..to Enviromental Report for Calendar Yoar 1990

Gross Alpha, Gross Bota, and Trition Conoentrations in Potable

Water and Dlatillod Wator exom Buildins 5358

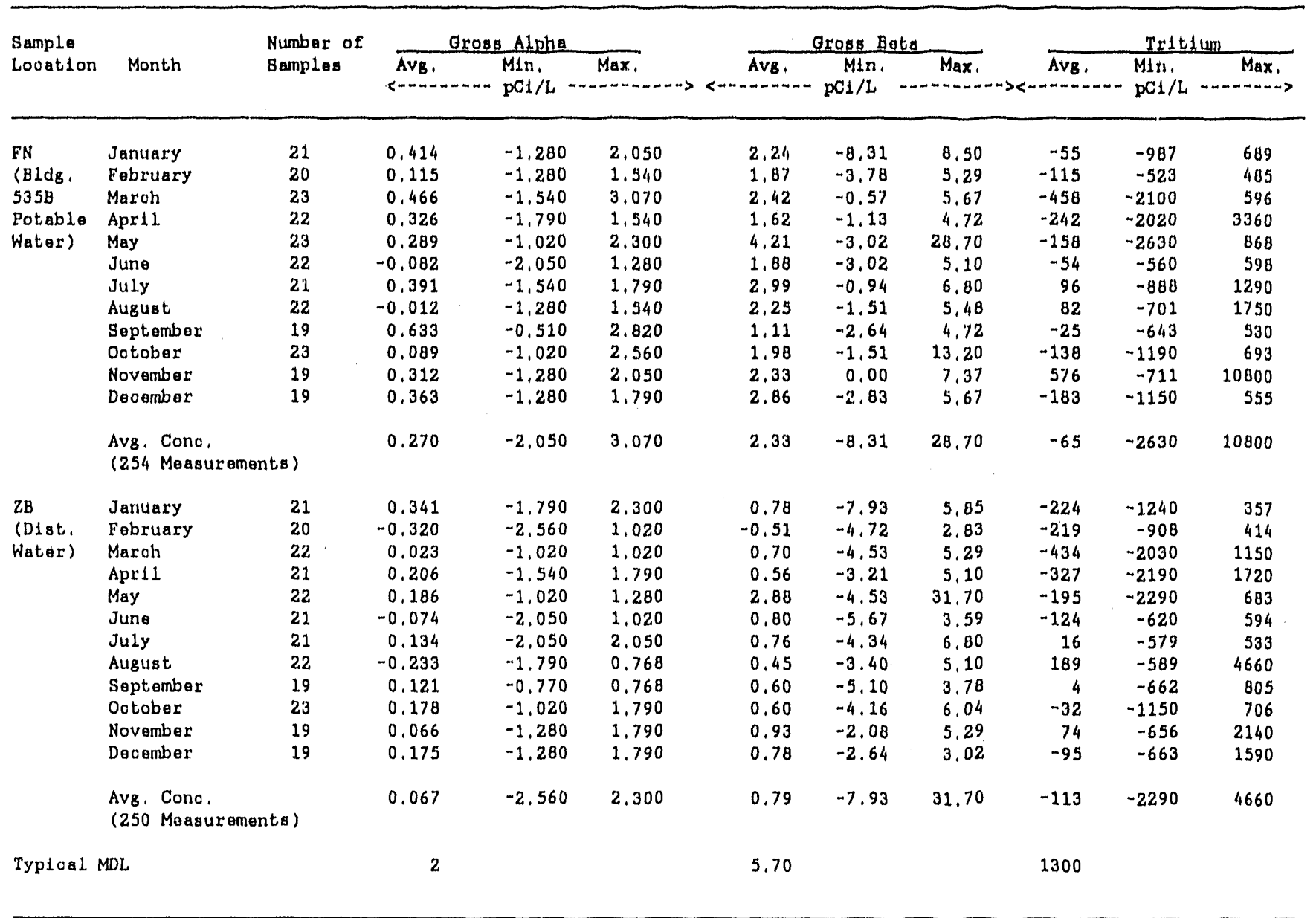

MDL: Minimum detection 11 mit. 


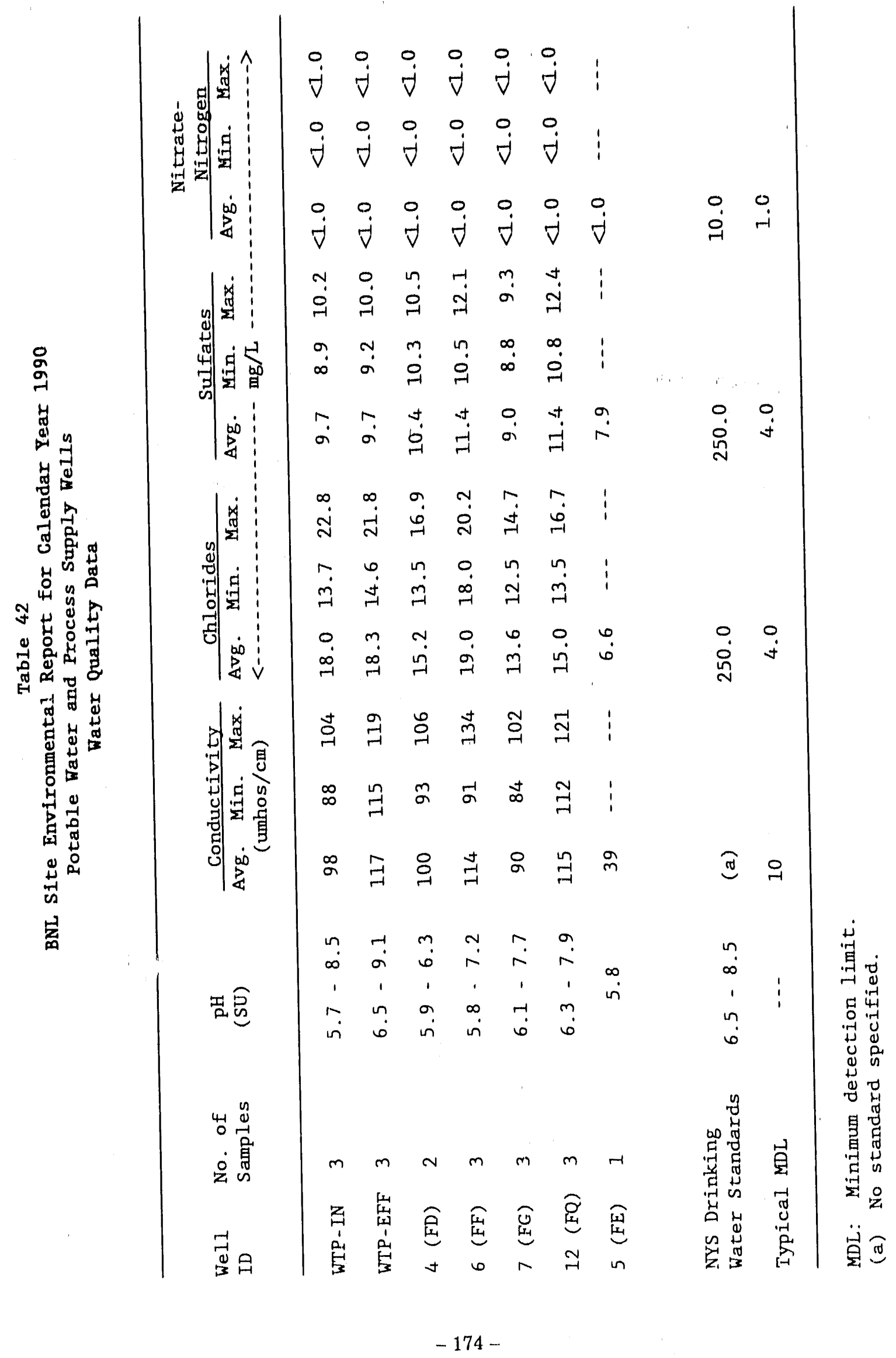




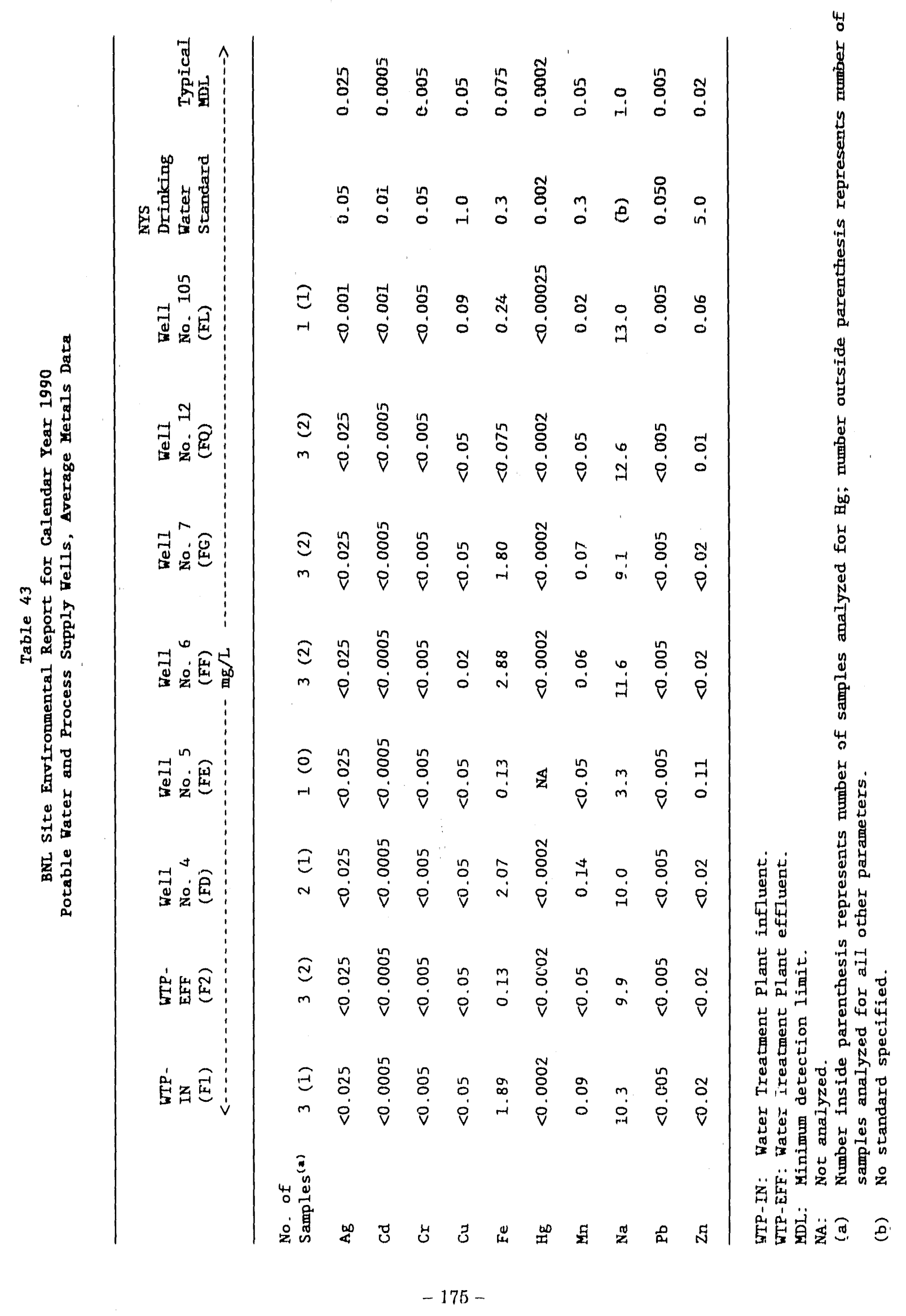




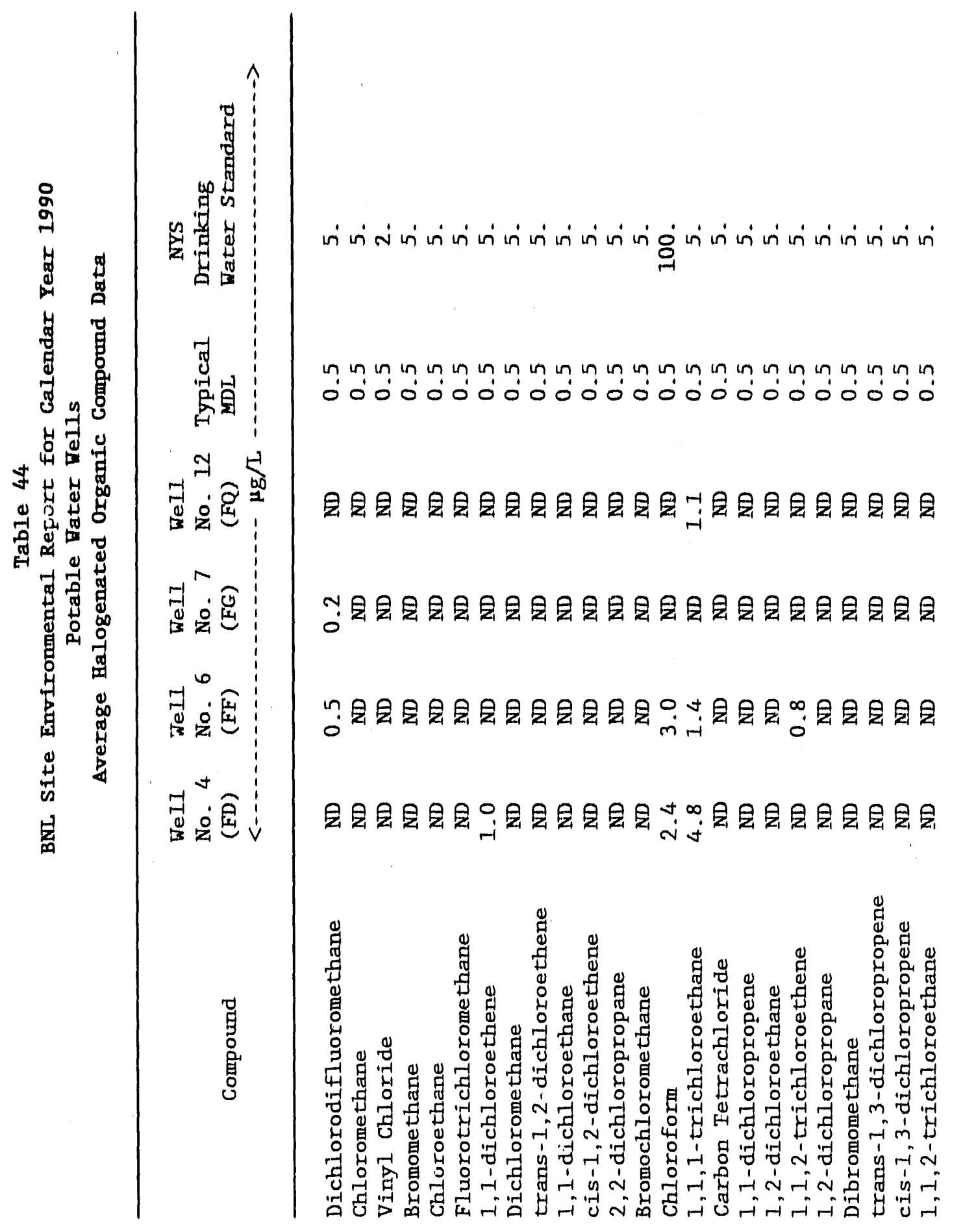




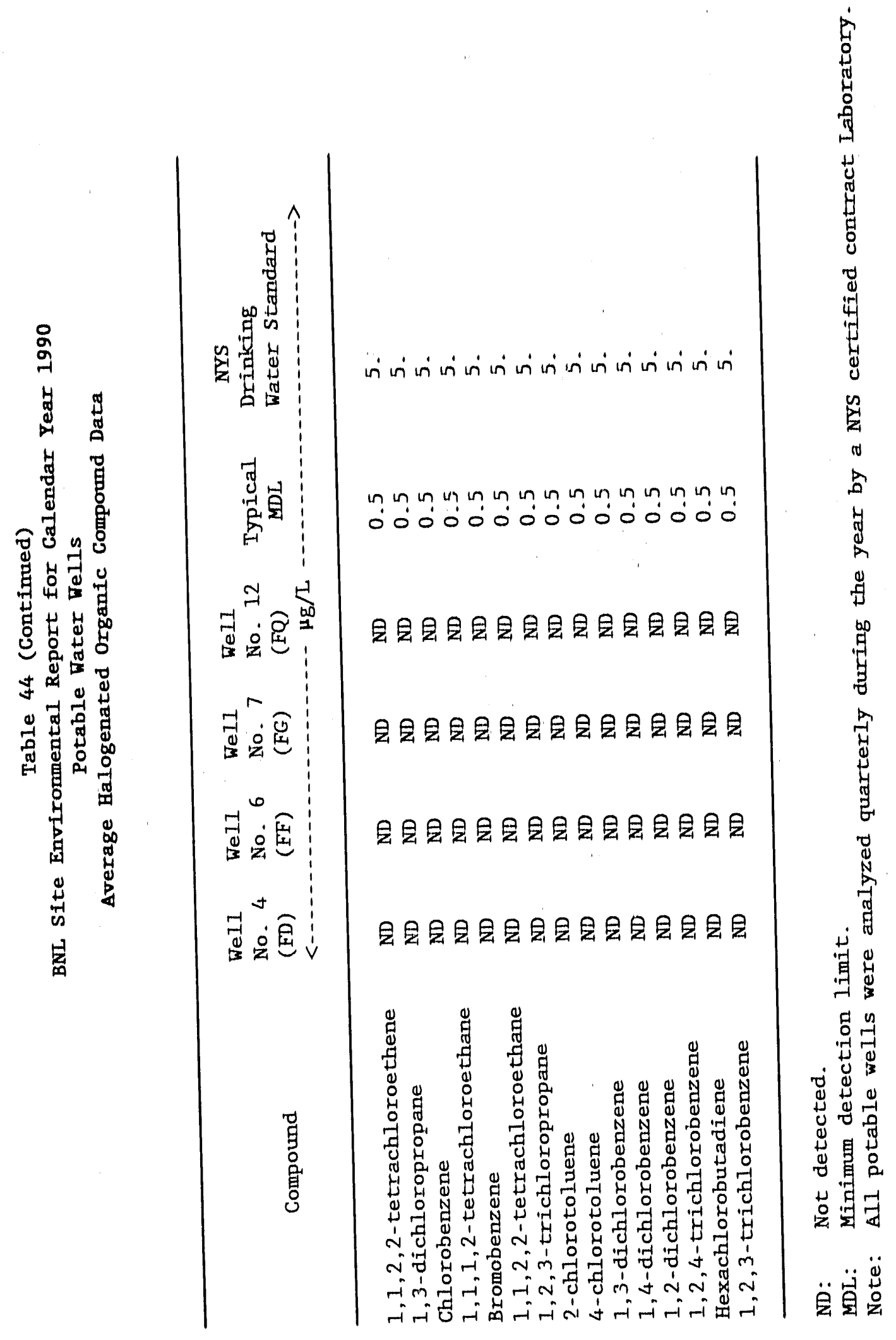




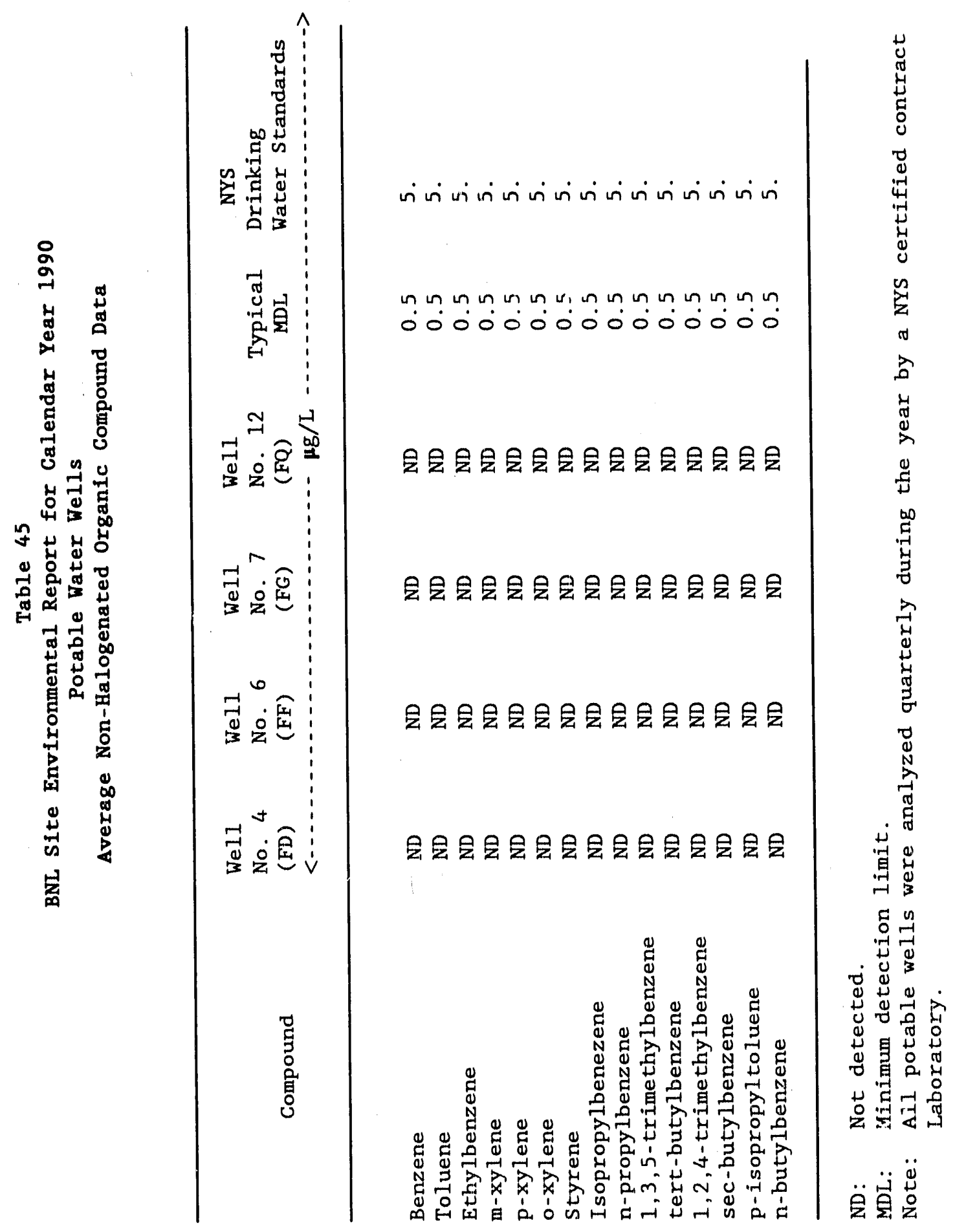


Table 46

BNL Site Environmental Report for Calendar Year 1990

Potable Water and Supply Wells

Chlorocarbon Data

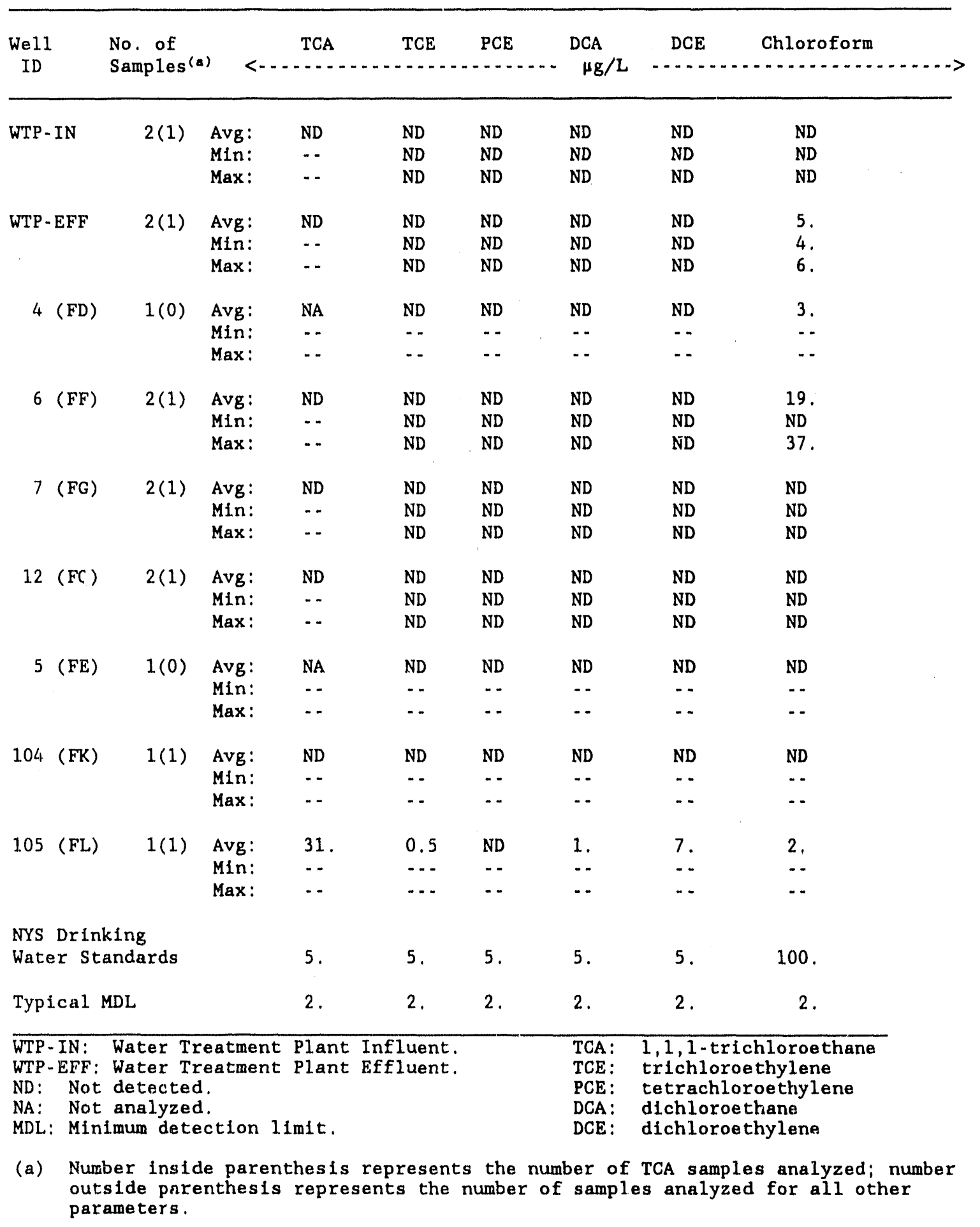


Tab1. 47

BNL S1te Environmental Report for Calendar Year 1990

Potable Water and Supply Wells,

BTX Data

\begin{tabular}{|c|c|c|c|c|c|c|c|}
\hline \multirow{2}{*}{$\begin{array}{l}\text { We } 11 \\
\text { ID }\end{array}$} & \multirow{2}{*}{$\begin{array}{l}\text { No. of } \\
\text { Samples(a) }\end{array}$} & & \multirow{2}{*}{ benzene } & \multicolumn{2}{|c|}{$\begin{array}{l}\text { ethyl- } \\
\text { benzene }\end{array}$} & \multirow{2}{*}{ toluene } & \multirow{2}{*}{ 0-xylene } \\
\hline & & & & $\cdots$ & $\mu g / L$ & & \\
\hline \multirow[t]{3}{*}{ WTP - IN } & $2(1)$ & Avg: & ND & ND & & ND & ND \\
\hline & & Min: & ND & ND & & ND & - \\
\hline & & Max: & ND & ND & & ND & $\cdots$ \\
\hline \multirow[t]{3}{*}{ WTP - EFF } & $2(1)$ & Avg: & ND & ND & & ND & ND \\
\hline & & Min: & ND & ND & & ND & -. \\
\hline & & Max: & ND & ND & & ND & $\cdots$ \\
\hline \multirow[t]{3}{*}{$4(F D)$} & $1(0)$ & Avg: & ND & ND & & ND & NA \\
\hline & & Min: & -- & $\cdots$ & & $\cdots$ & -- \\
\hline & & Max: & $\cdots$ & $\cdots$ & & $\cdots$ & -- \\
\hline \multirow[t]{3}{*}{$6(F F)$} & $2(1)$ & Avg: & ND & ND & & ND & ND \\
\hline & & Min: & ND & ND & & ND & $-\cdot$ \\
\hline & & Max: & ND & ND & & ND & $\cdots$ \\
\hline \multirow[t]{3}{*}{$7(F G)$} & $2(1)$ & Avg: & ND & ND & & ND & ND \\
\hline & & Min: & ND & ND & & ND & $\cdots$ \\
\hline & & Max: & ND & ND & & ND & $\cdots$ \\
\hline \multirow[t]{3}{*}{$12(F Q)$} & $2(1)$ & Avg: & ND & ND & & ND & ND \\
\hline & & Min: & ND & ND & & ND & $\cdots$ \\
\hline & & Max: & ND & ND & & ND & - \\
\hline \multirow[t]{3}{*}{$5(\mathrm{FE})$} & $1(0)$ & Avg: & ND & ND & & ND & NA \\
\hline & & Min: & $\cdots$ & $\cdots$ & & $\cdots$ & $\cdots$ \\
\hline & & Max: & $\cdots$ & $\cdots$ & & $\cdots$ & $\cdots$ \\
\hline \multirow[t]{3}{*}{$104(\mathrm{FK})$} & $1(1)$ & Avg: & ND & ND & & ND & ND \\
\hline & & Min: & $\cdots$ & $\cdots$ & & $\cdots$ & $-\cdot$ \\
\hline & & Max: & $\cdots$ & $\cdots$ & & $\cdots$ & $\cdots$ \\
\hline \multirow[t]{3}{*}{105 (FL) } & $1(0)$ & Avg: & ND & ND & & ND & NA \\
\hline & & Min: & $\cdots$ & $\cdots$ & & $\cdots$ & -- \\
\hline & & Max: & $\cdots$ & $\cdots$ & & - & $\cdots$ \\
\hline \multirow{2}{*}{\multicolumn{2}{|c|}{$\begin{array}{l}\text { NYS Drinking } \\
\text { Water Standards }\end{array}$}} & & & & & & \\
\hline & & & 5. & 5 & & 5. & 5. \\
\hline \multicolumn{2}{|c|}{ Typical MDL } & & 2. & 2 . & & 2 . & 2 . \\
\hline
\end{tabular}

WTP-IN: Water Treatment Plant influent.

WTP-EFF: Water Treatment Plant effluent.

ND: Not detected.

NA: Not analyzed.

MDL: Minimum detection limit.

(a) Number inside parenthesis represents the number of o-xylene samples analyzed; number outside parenthesis represents the number of samples analyzed for all other parameters. 


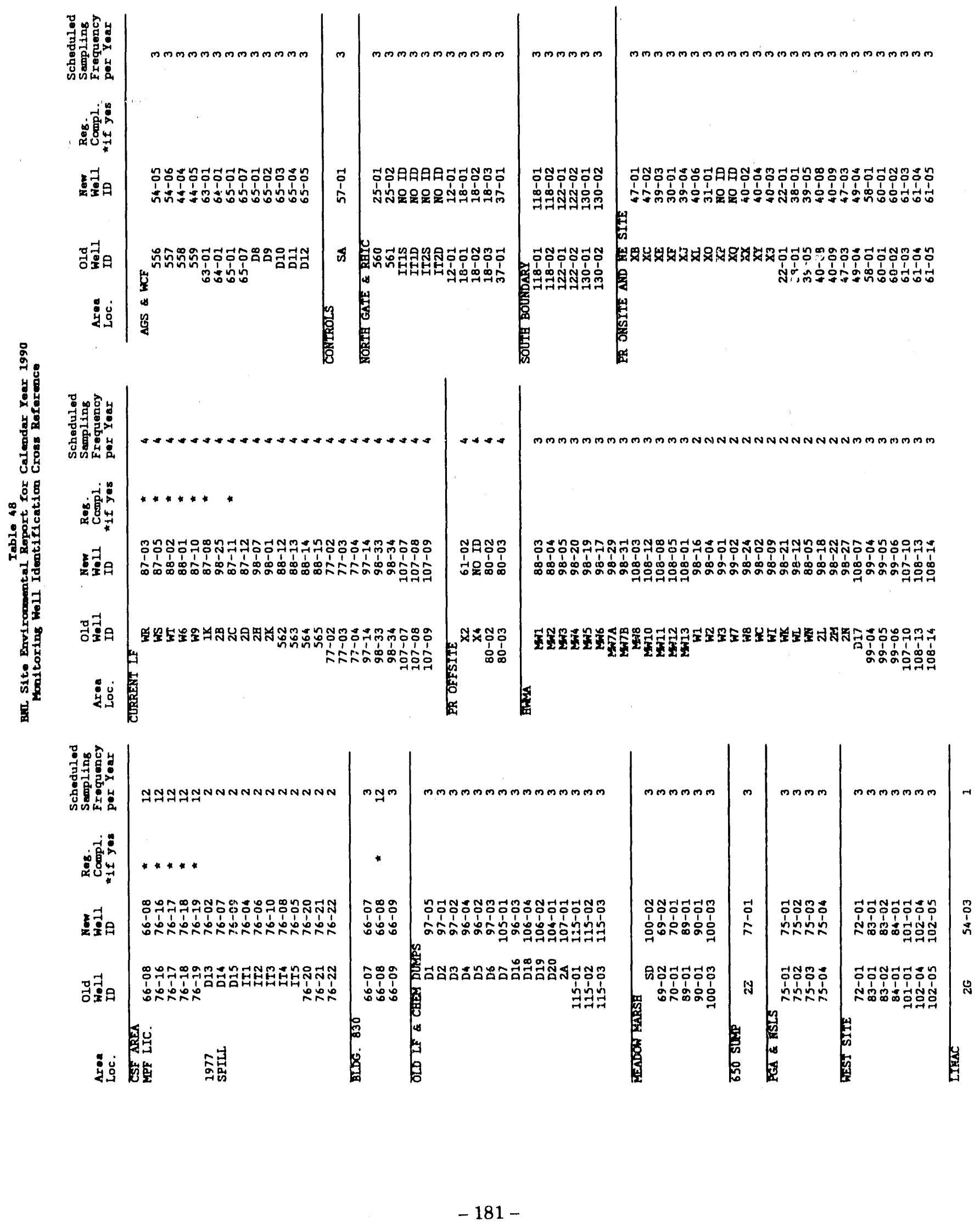


Table 49

BNL Site Environmental Report for Calendar Year 1990

Radionuclide Concentrations in Field Blank Samples

\begin{tabular}{|c|c|c|c|c|c|c|c|c|}
\hline Month & $\begin{array}{l}\text { Gross } \\
\text { Alpha }\end{array}$ & $\begin{array}{l}\text { Gross } \\
\text { Beta }\end{array}$ & Tritium & $\mathrm{K}-40$ & $\mathrm{Ra}-226$ & Th-228 & $\mathrm{Cs}-137$ & Sr -90 \\
\hline January & 0.10 & 0.15 & 49 & ND & ND & ND & ND & 0.19 \\
\hline February & -0.10 & -0.42 & 408 & ND & ND & ND & ND & -0.11 \\
\hline March & -0.10 & 0.08 & 135 & ND & ND & ND & ND & -0.08 \\
\hline April & 0.10 & 0.83 & 16 & ND & 0.93 & ND & ND & -0.30 \\
\hline May & 0.10 & -0.07 & -155 & NA & NA & NA & NA & -0.12 \\
\hline June & -0.20 & -0.87 & 55 & ND & ND & ND & ND & -0.17 \\
\hline July & 0.15 & -0.60 & 16 & ND & ND & ND & ND & 0.14 \\
\hline August & -0.15 & 0.19 & 54 & 38.5 & ND & ND & ND & 0.07 \\
\hline September & 0.15 & -0.11 & 308 & ND & ND & ND & ND & -0.02 \\
\hline October & 0.00 & 0.30 & 126 & ND & ND & $\therefore D$ & ND & NR \\
\hline November & NA & $\mathrm{NA}$ & NA & 2.8 & ND & IND & ND & NR \\
\hline December & 0.00 & 0.64 & 149 & $\mathrm{NA}$ & NA & NA & NA & NR \\
\hline Average & 0.01 & 0.01 & 97 & 3.4 & 0.1 & 0.0 & 0.0 & -0.03 \\
\hline Minimum & -0.20 & -0.87 & -155 & 2.8 & 0.0 & 0.0 & 0.0 & -0.30 \\
\hline Maximum & 0.15 & 0.83 & 408 & 38.5 & 0.9 & 0.0 & 0.0 & 0.19 \\
\hline $\begin{array}{l}\text { Typical } \\
\text { MDL }\end{array}$ & 0.53 & 1.20 & 300 & 3.9 & 0.5 & 0.43 & 0.2 & 0.1 \\
\hline
\end{tabular}

ND: Not detected.

NA. Not analyzed.

NR: Not reported.

MDL: Minimum detection limit . 


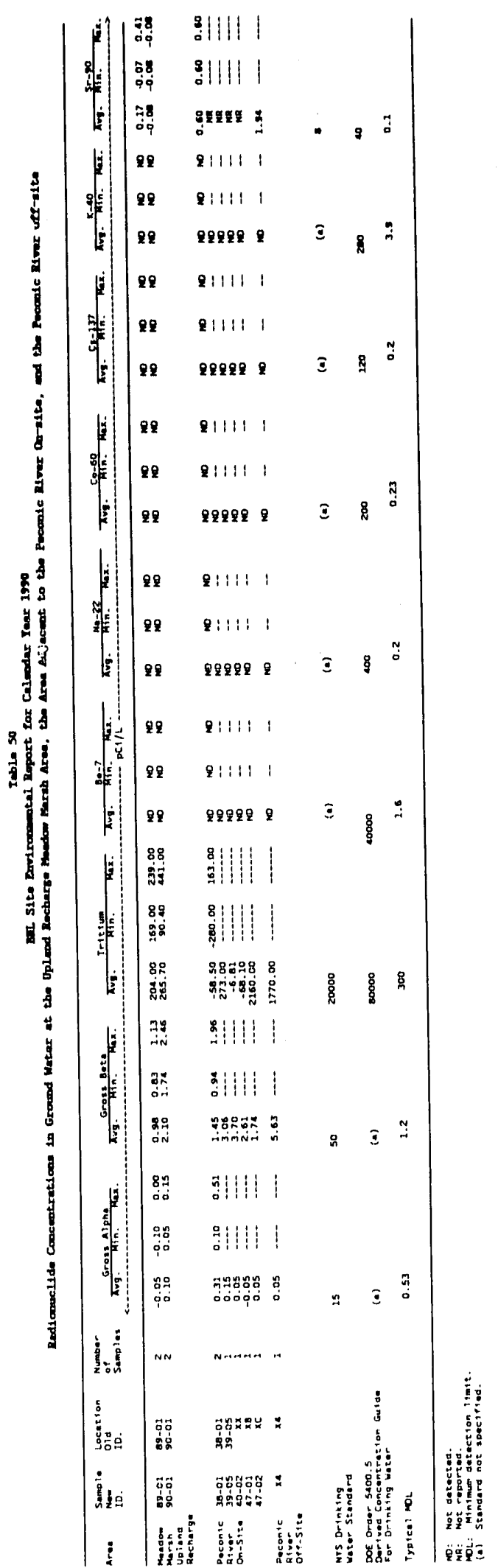




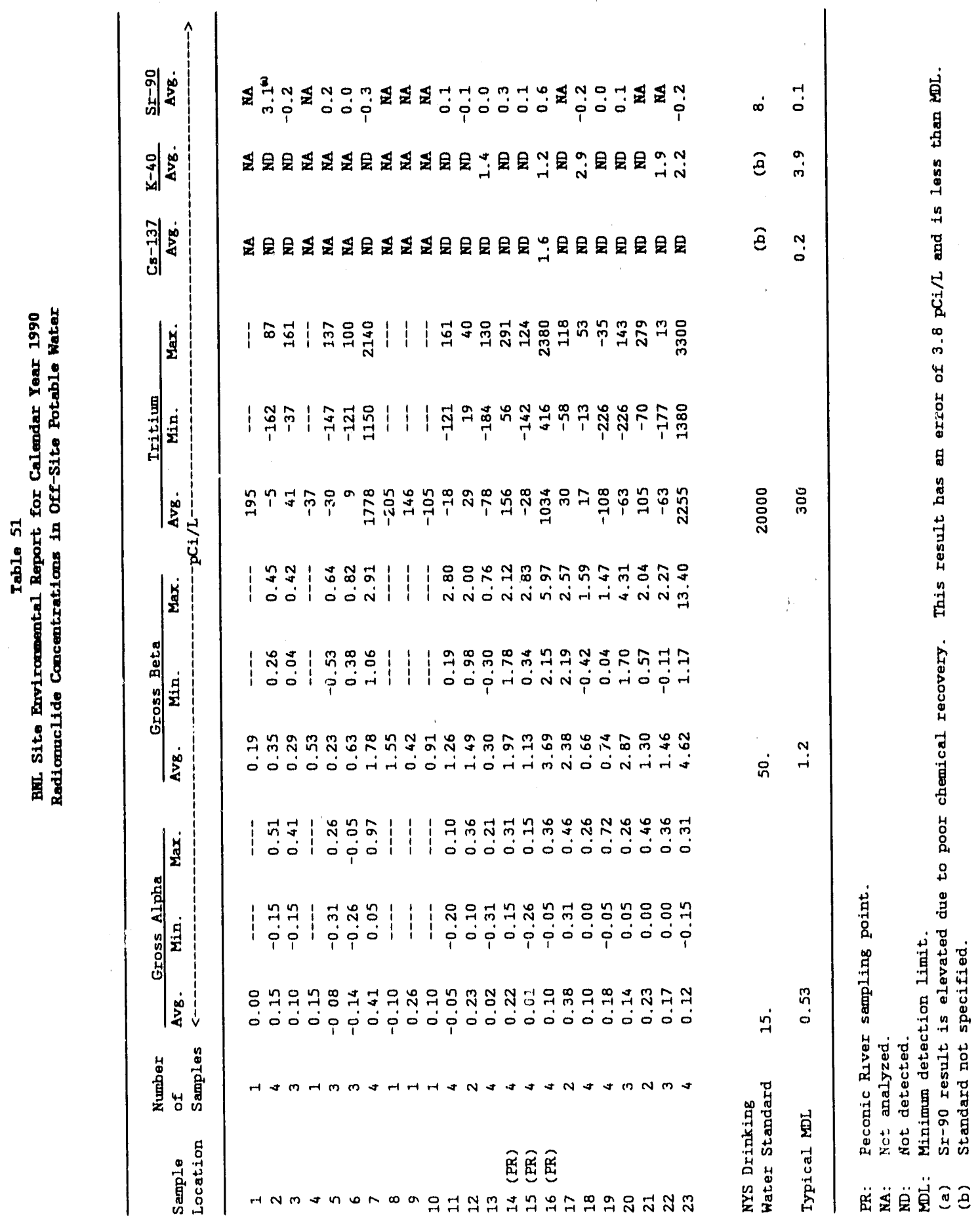




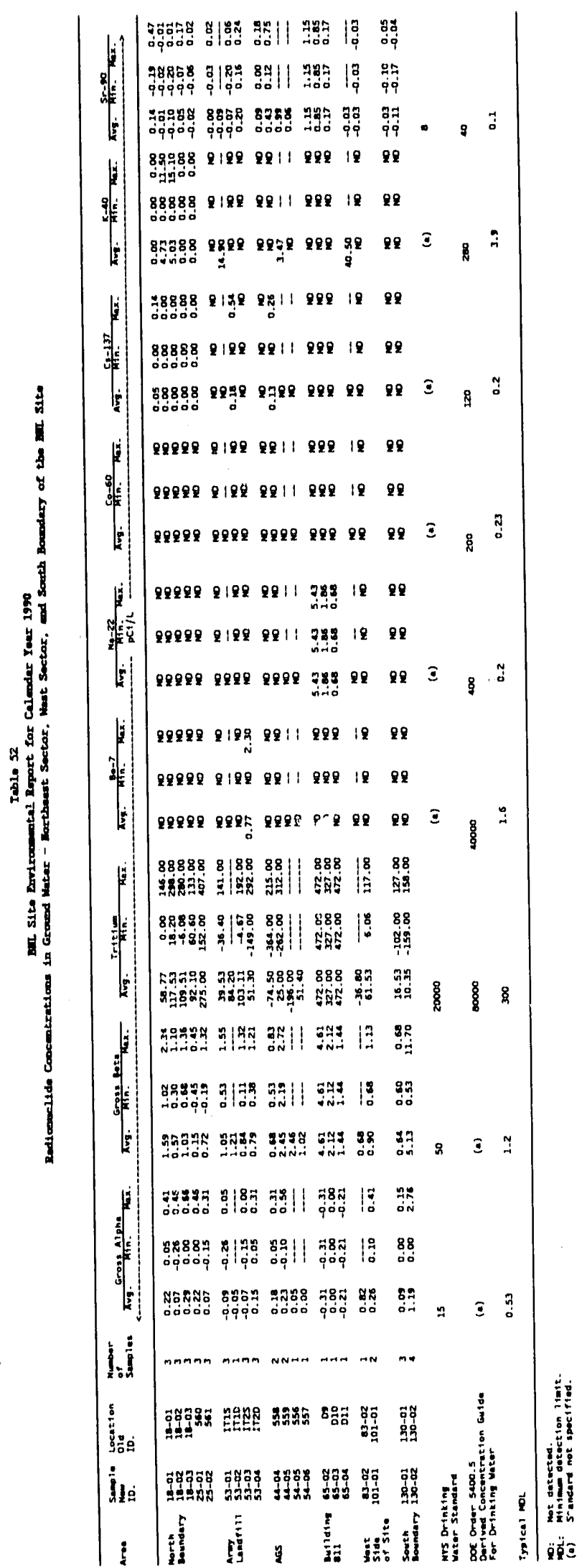




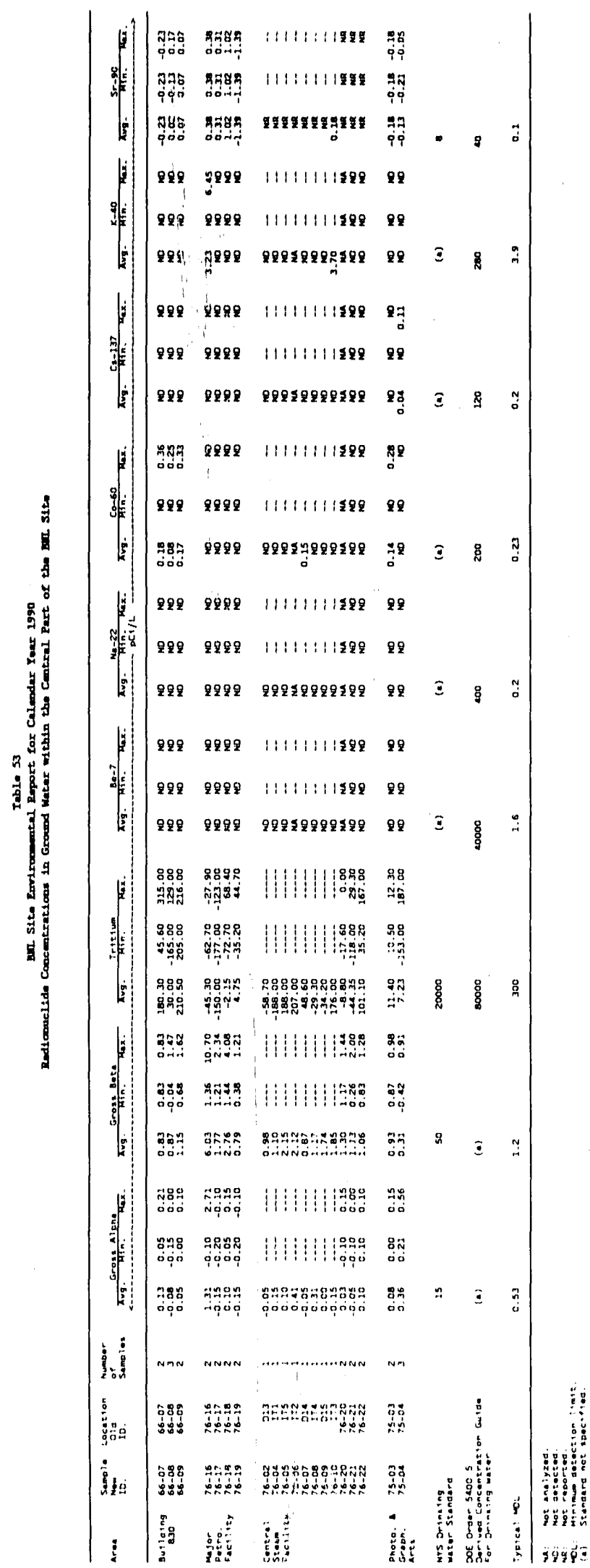




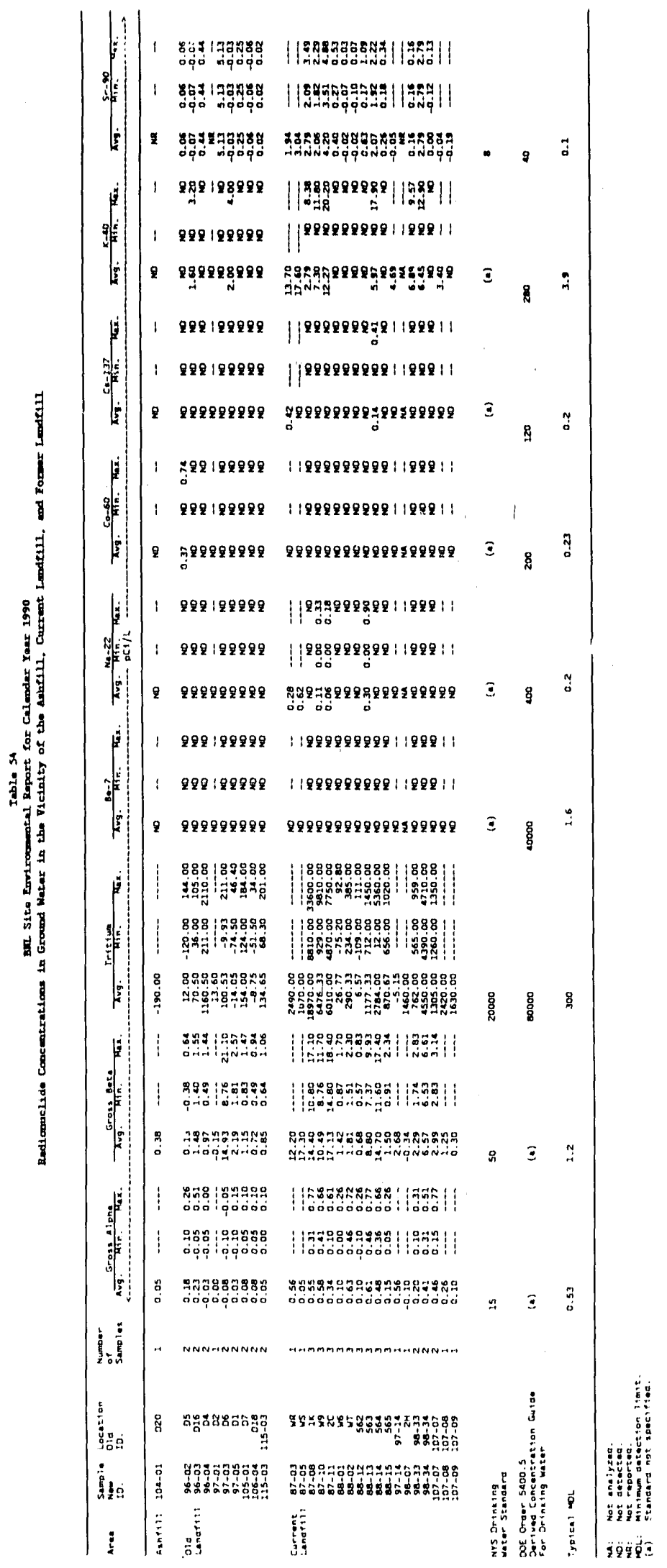




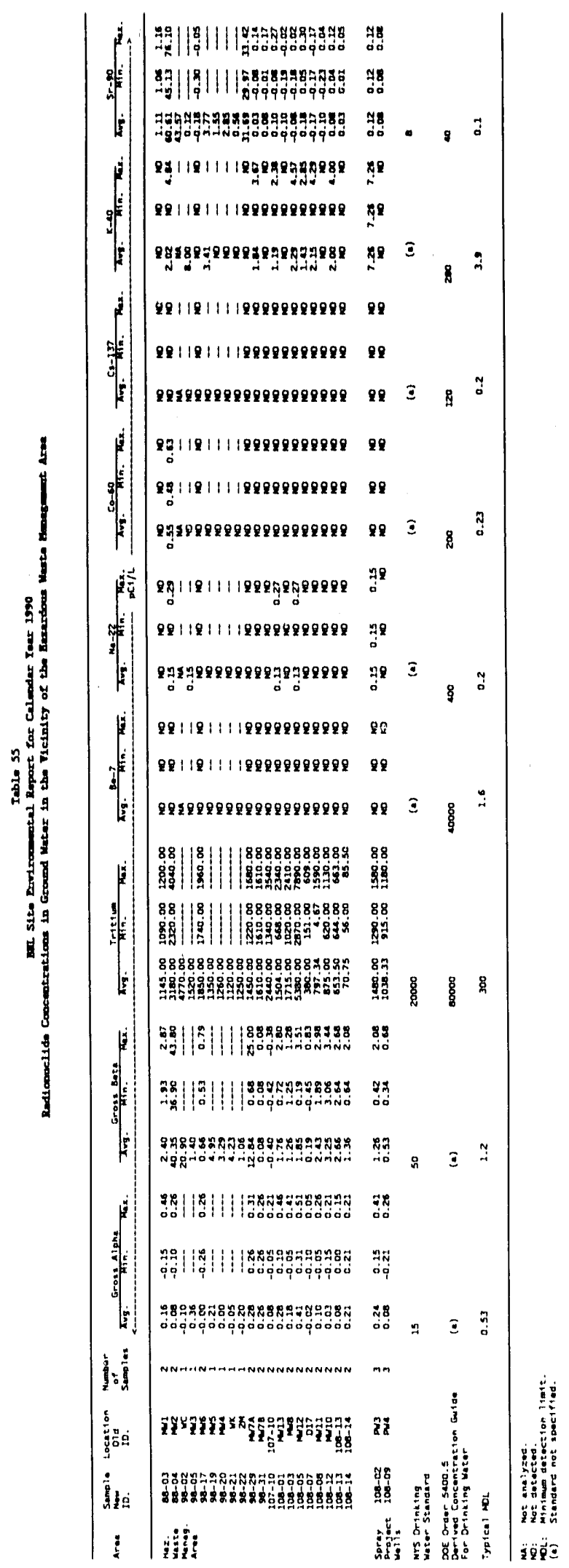




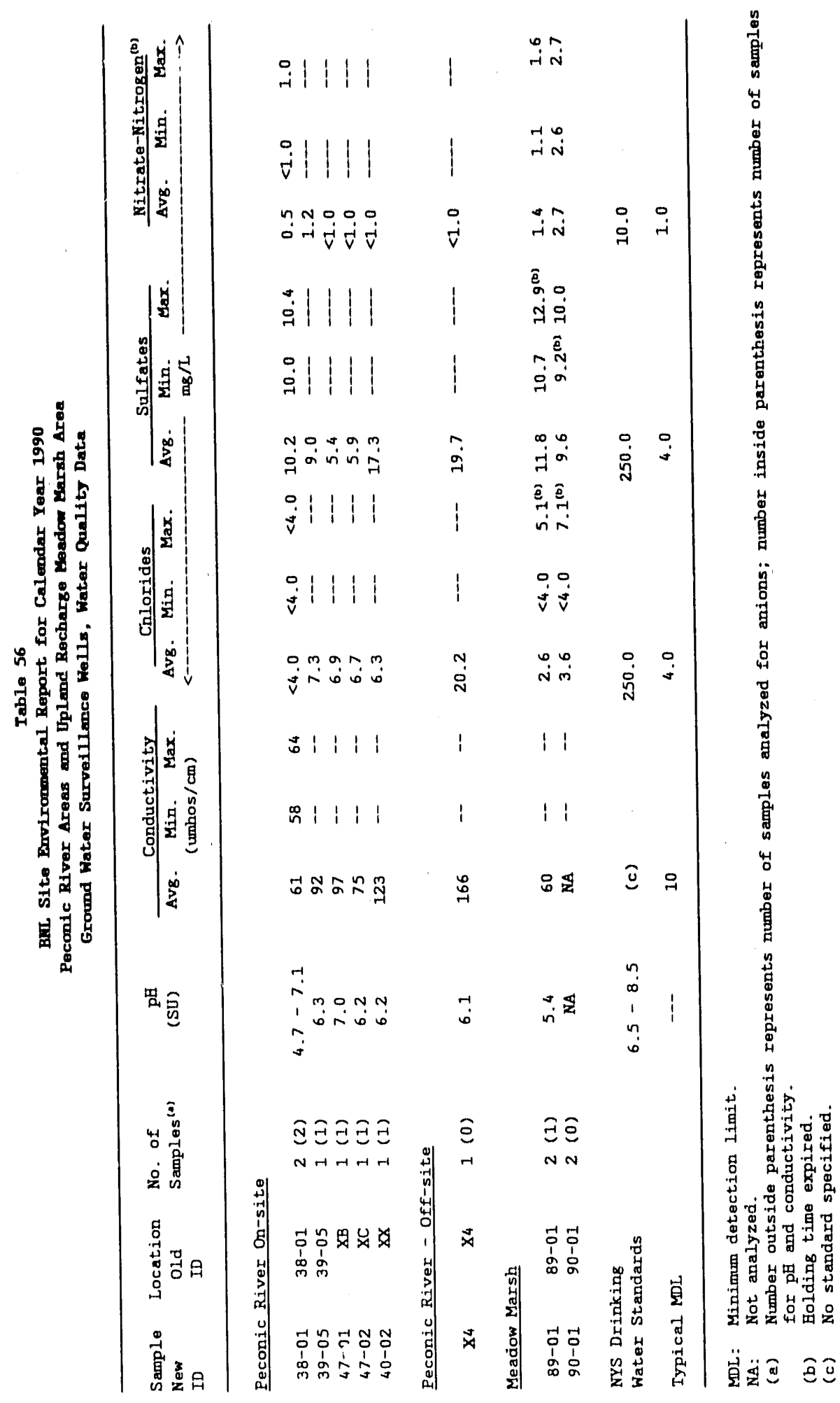




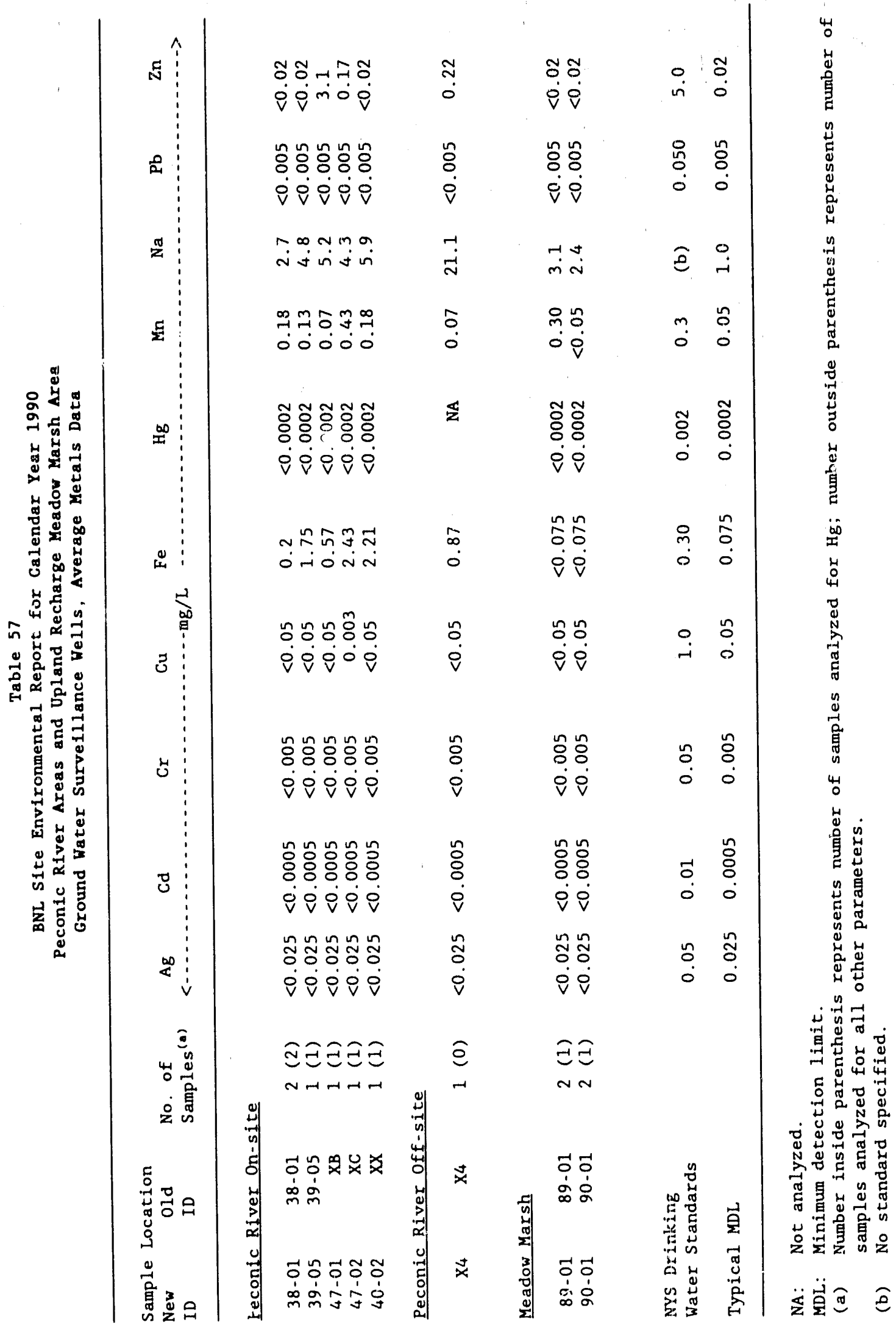




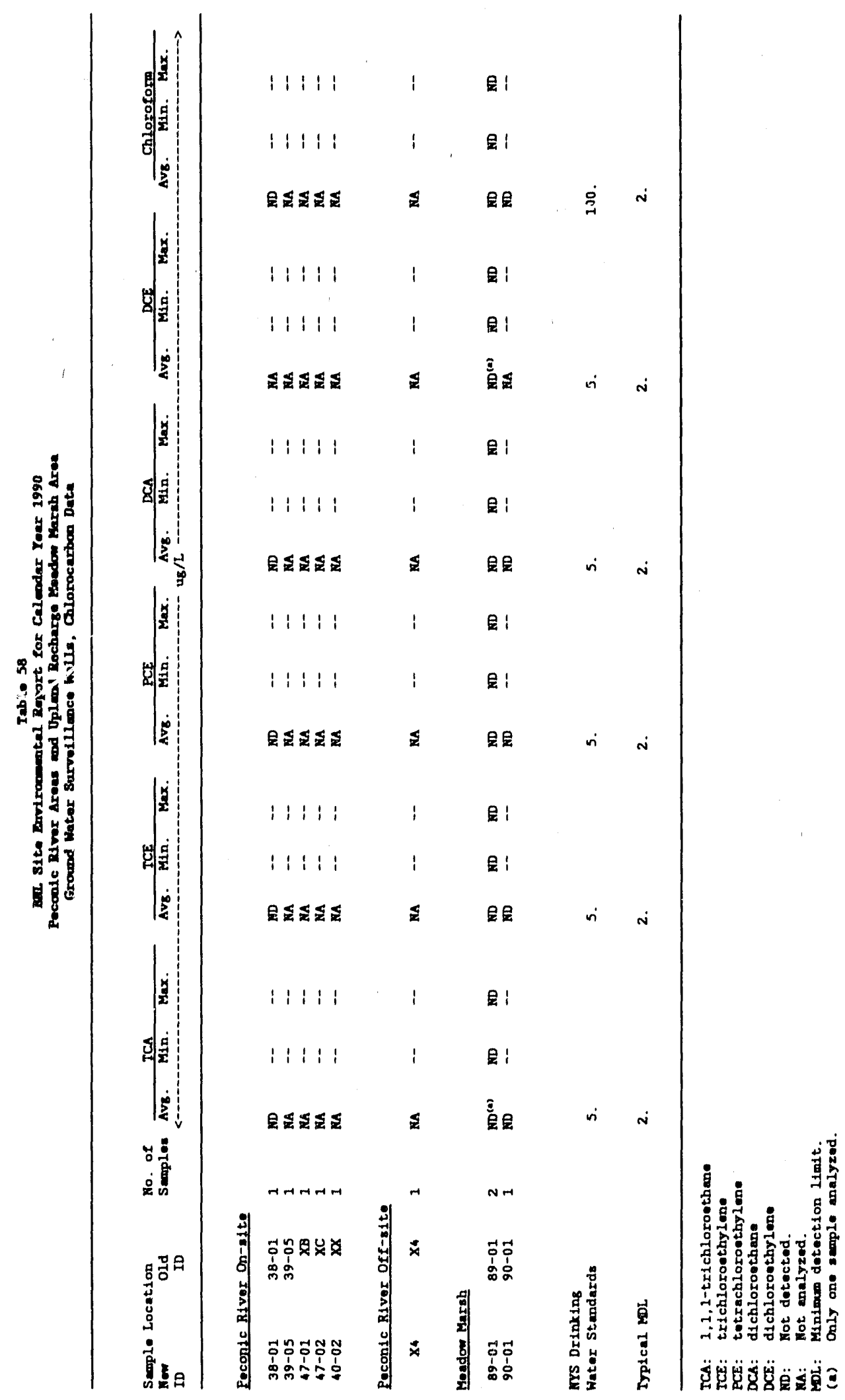




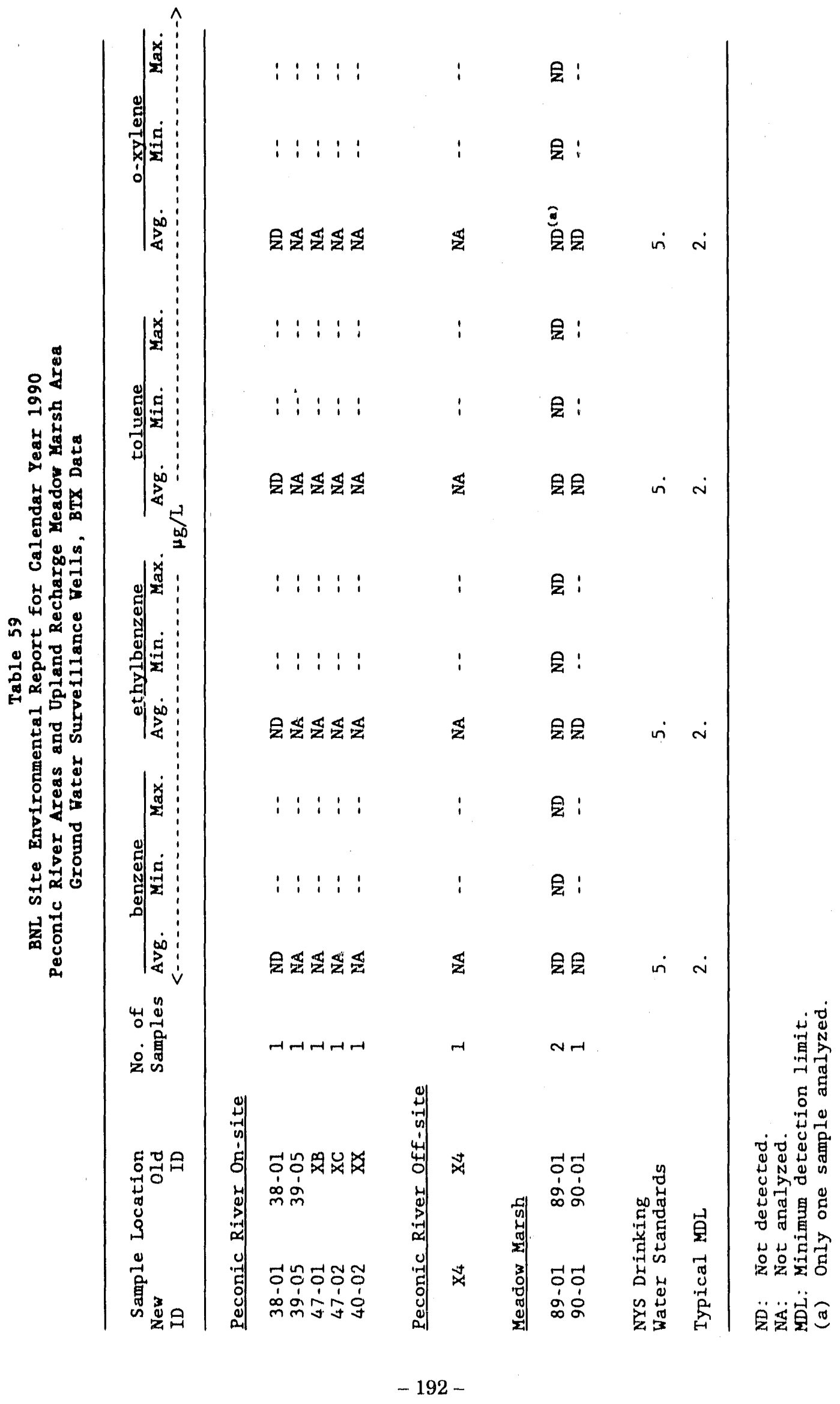




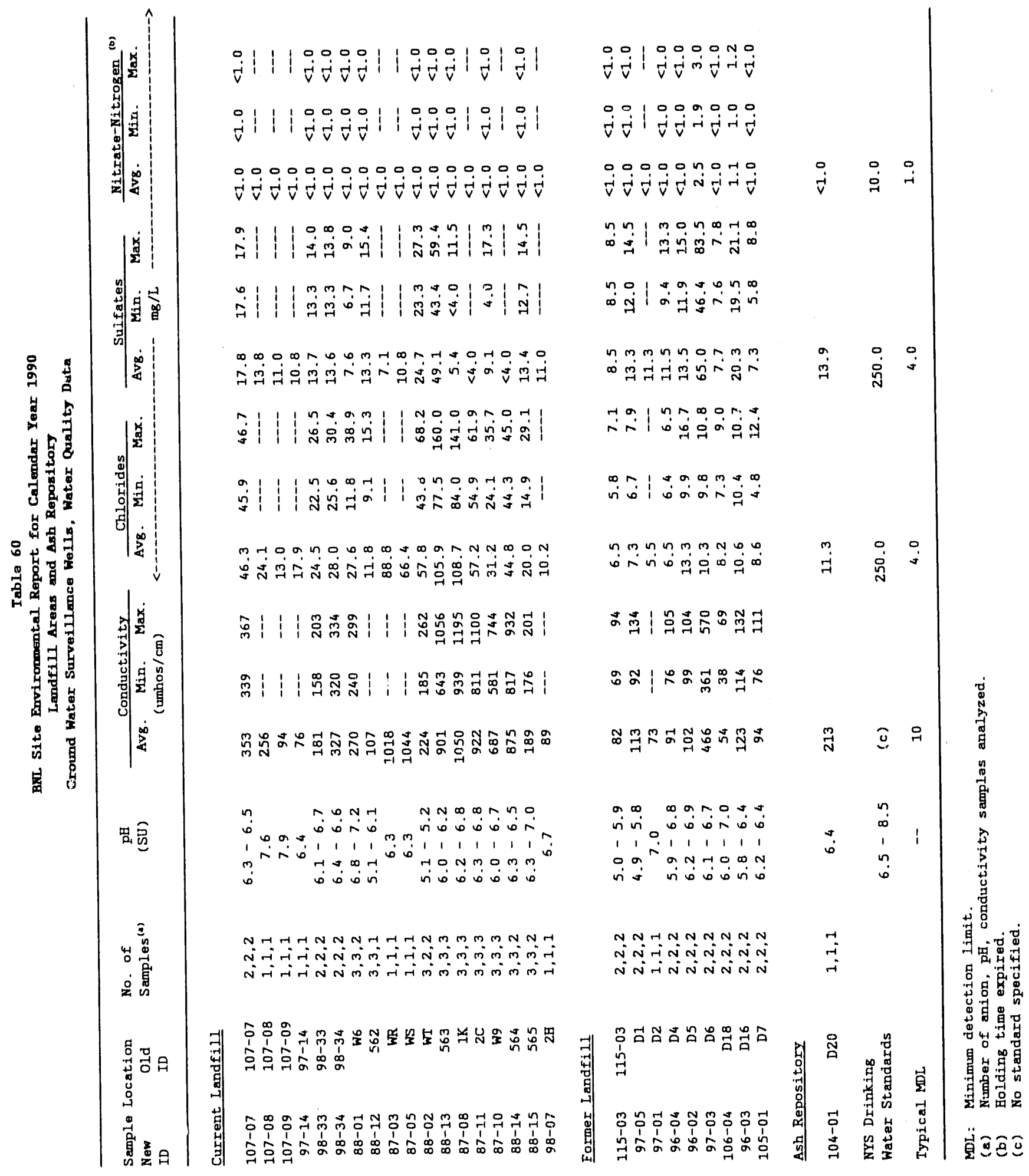




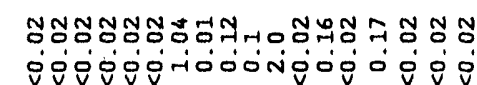

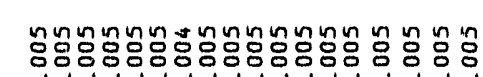

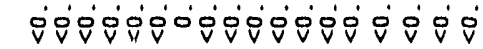

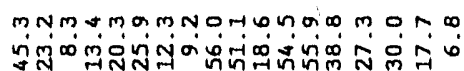
ชNo

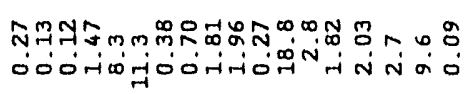

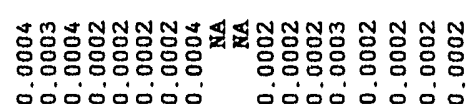

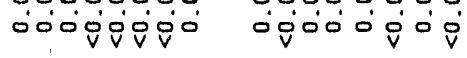

กำกำกำ

No000000ma

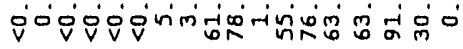

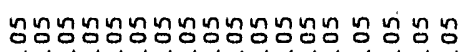

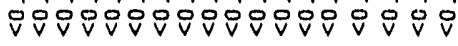

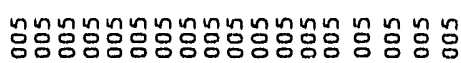

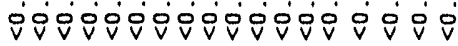

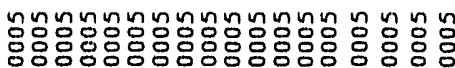

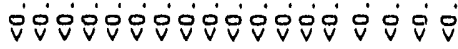

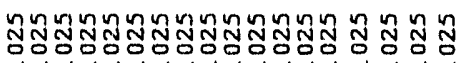

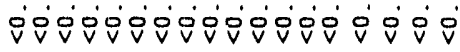

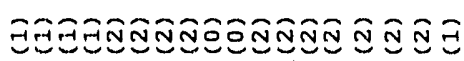
NHHHNNMMHHMMMM M M M H

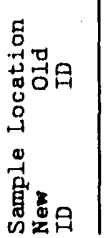

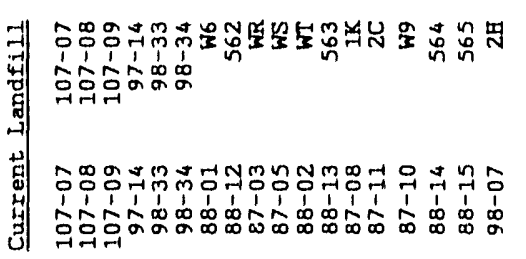

R. o 0 iे

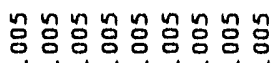
iिं 0 i 0 iे

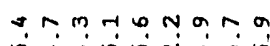

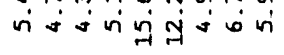

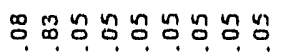
óg

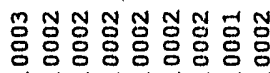
i $\dot{v} \dot{v} \dot{v} \dot{v} 0 \dot{0}$

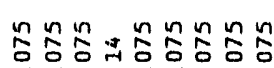
io 0 o

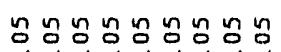

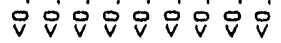

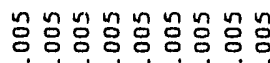

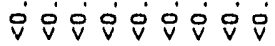

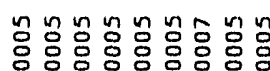
ivioiogi

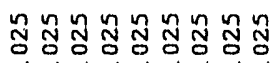

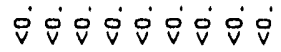

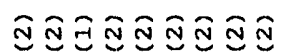
NNANNNNNN

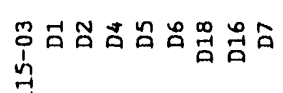
$\stackrel{1}{\ddots}$

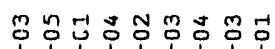

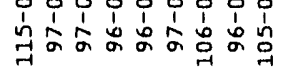




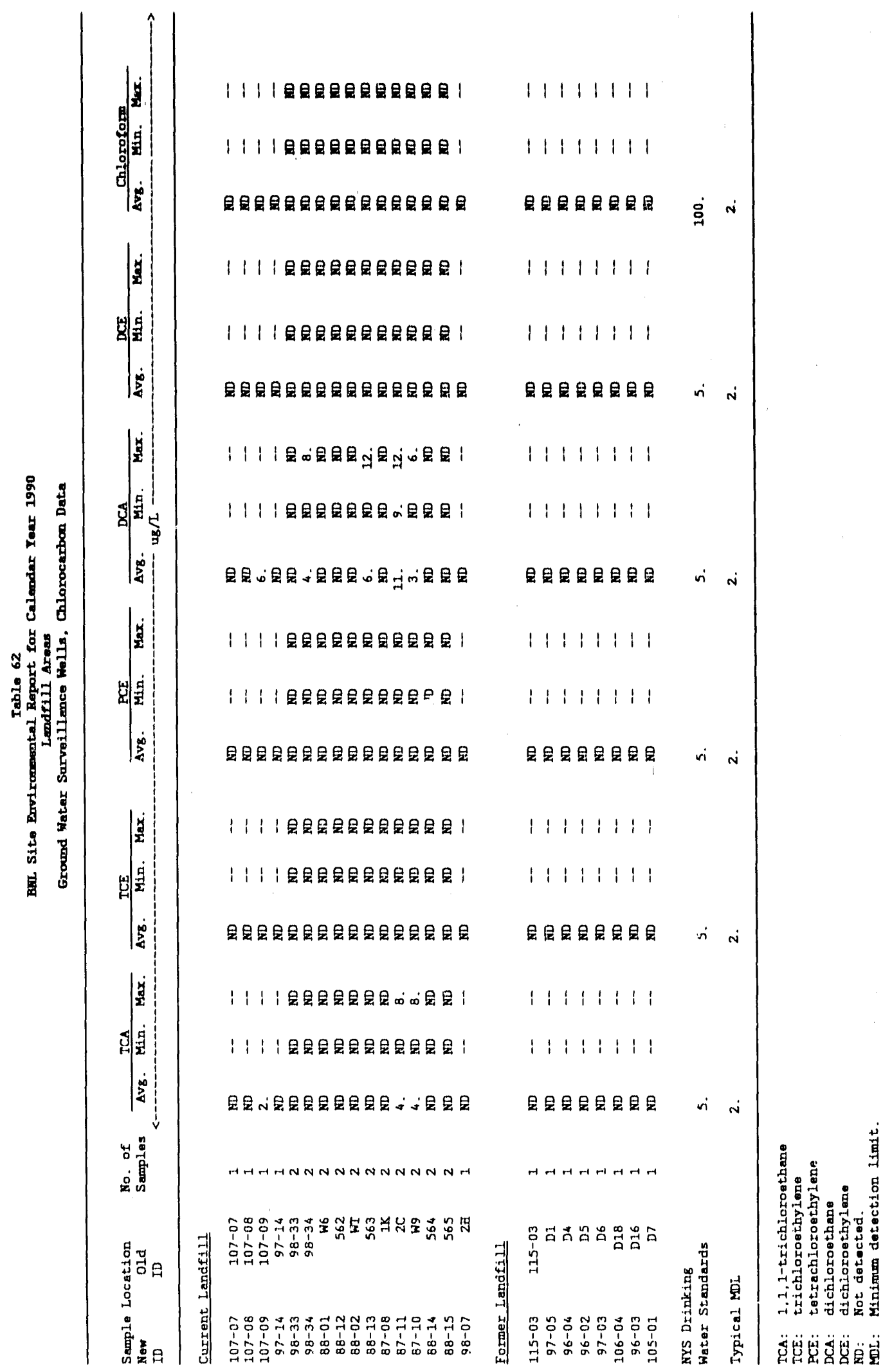




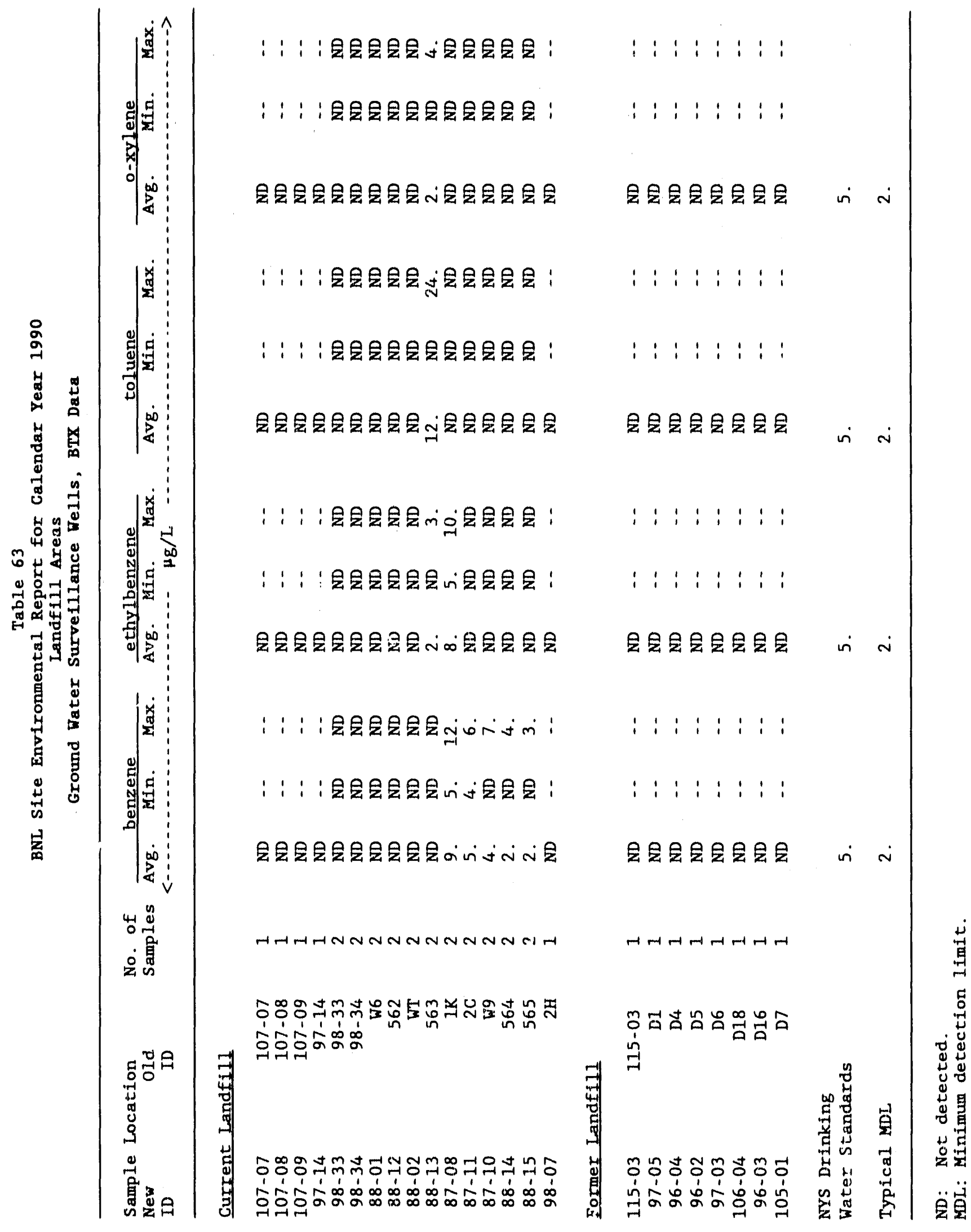




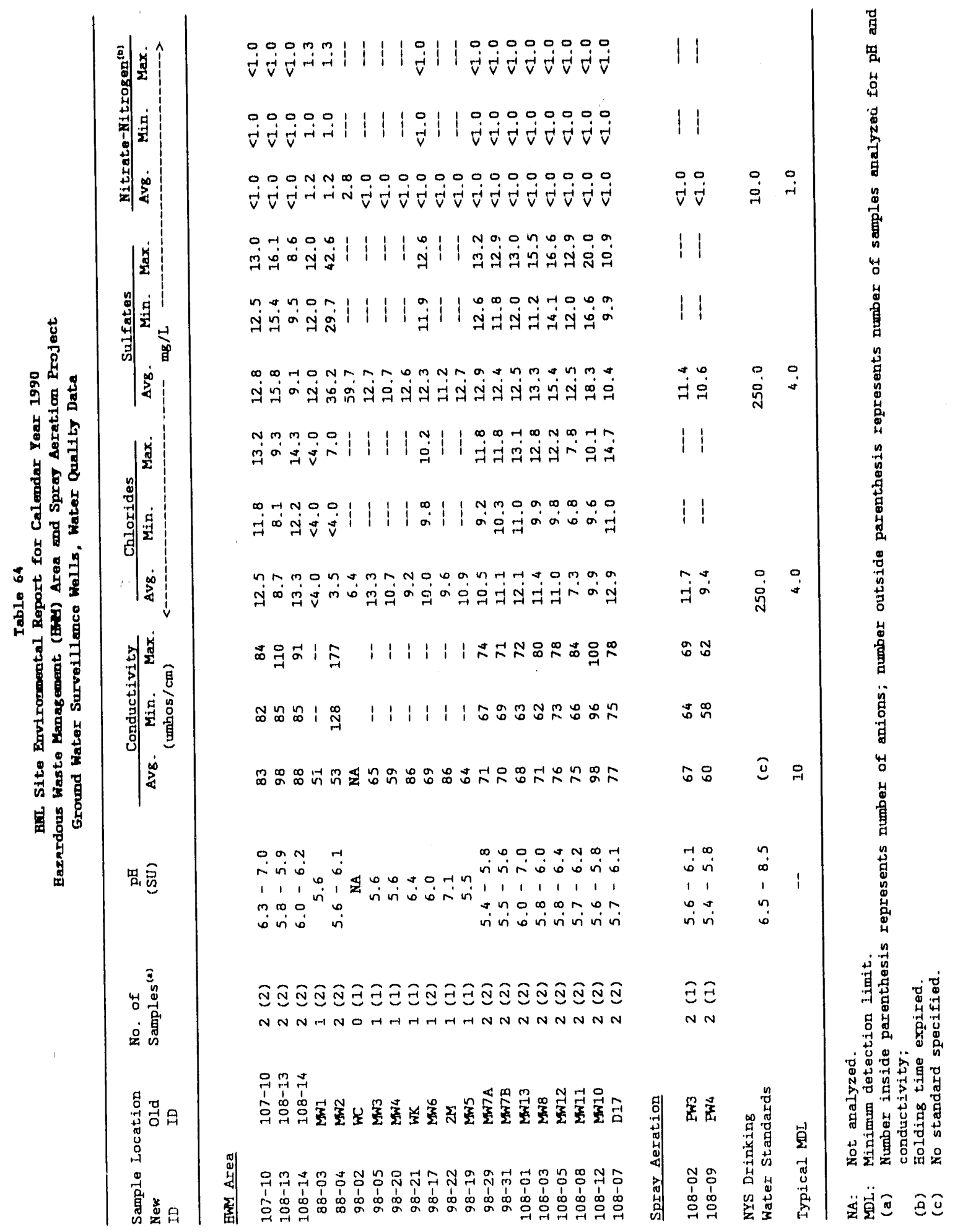




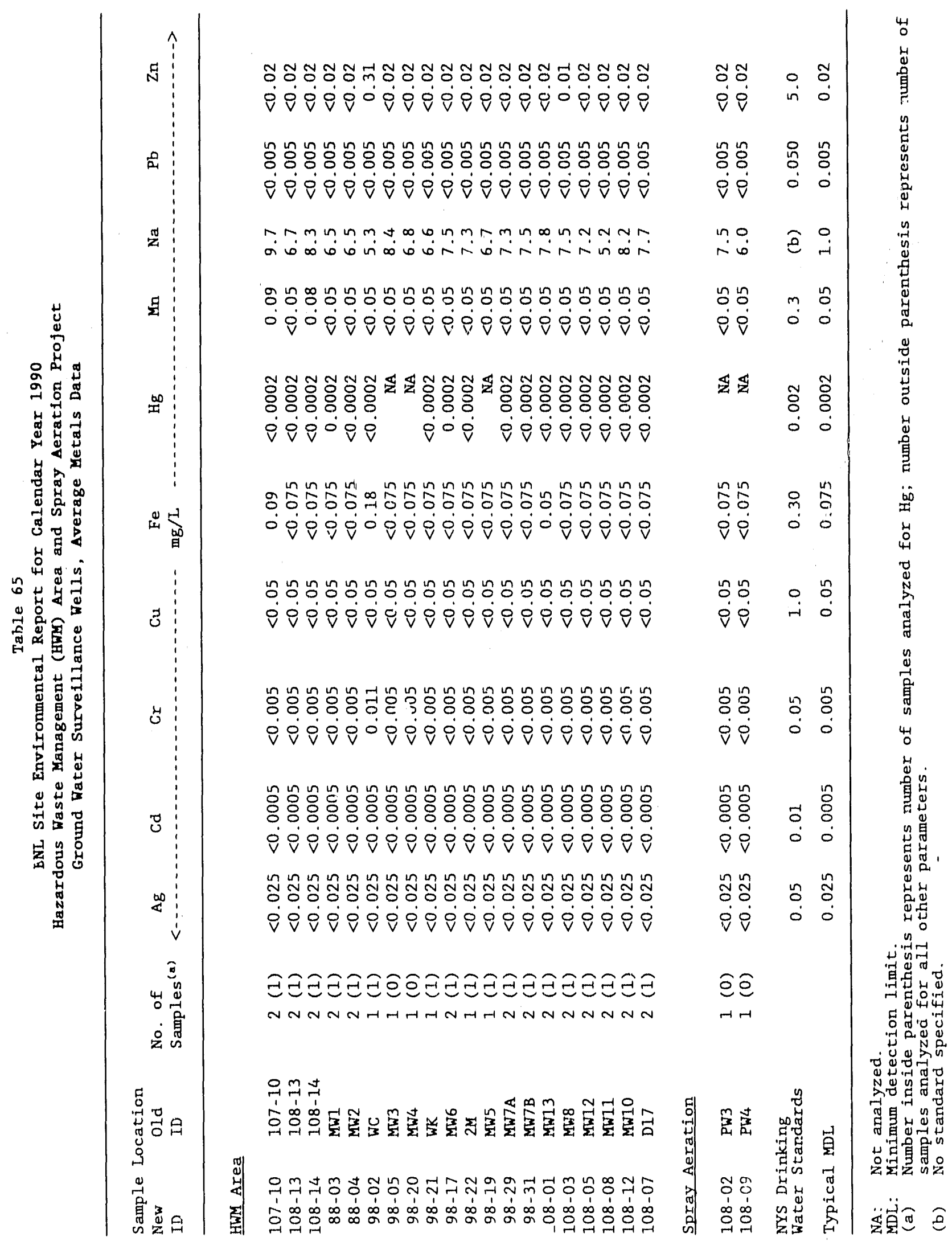




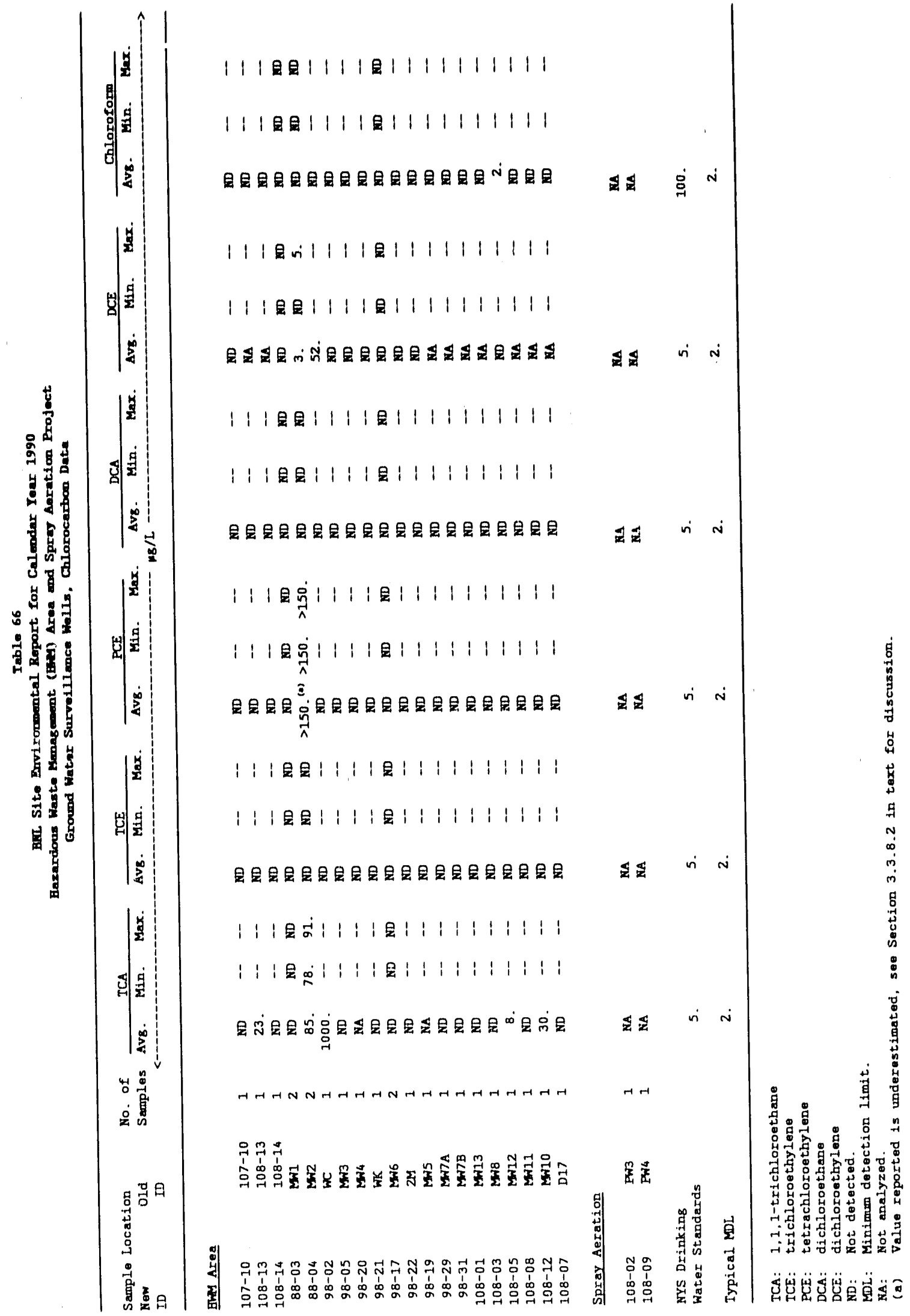




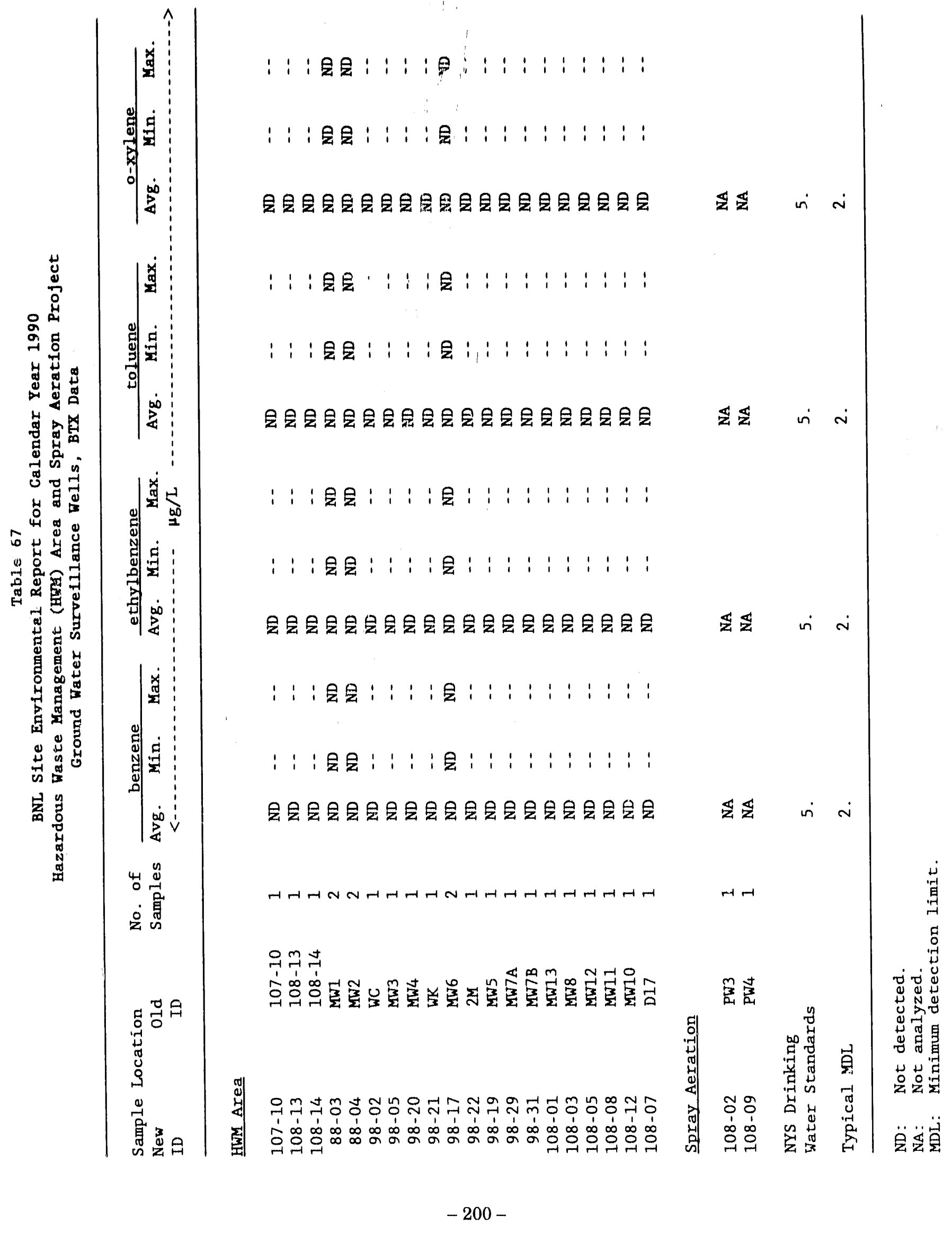




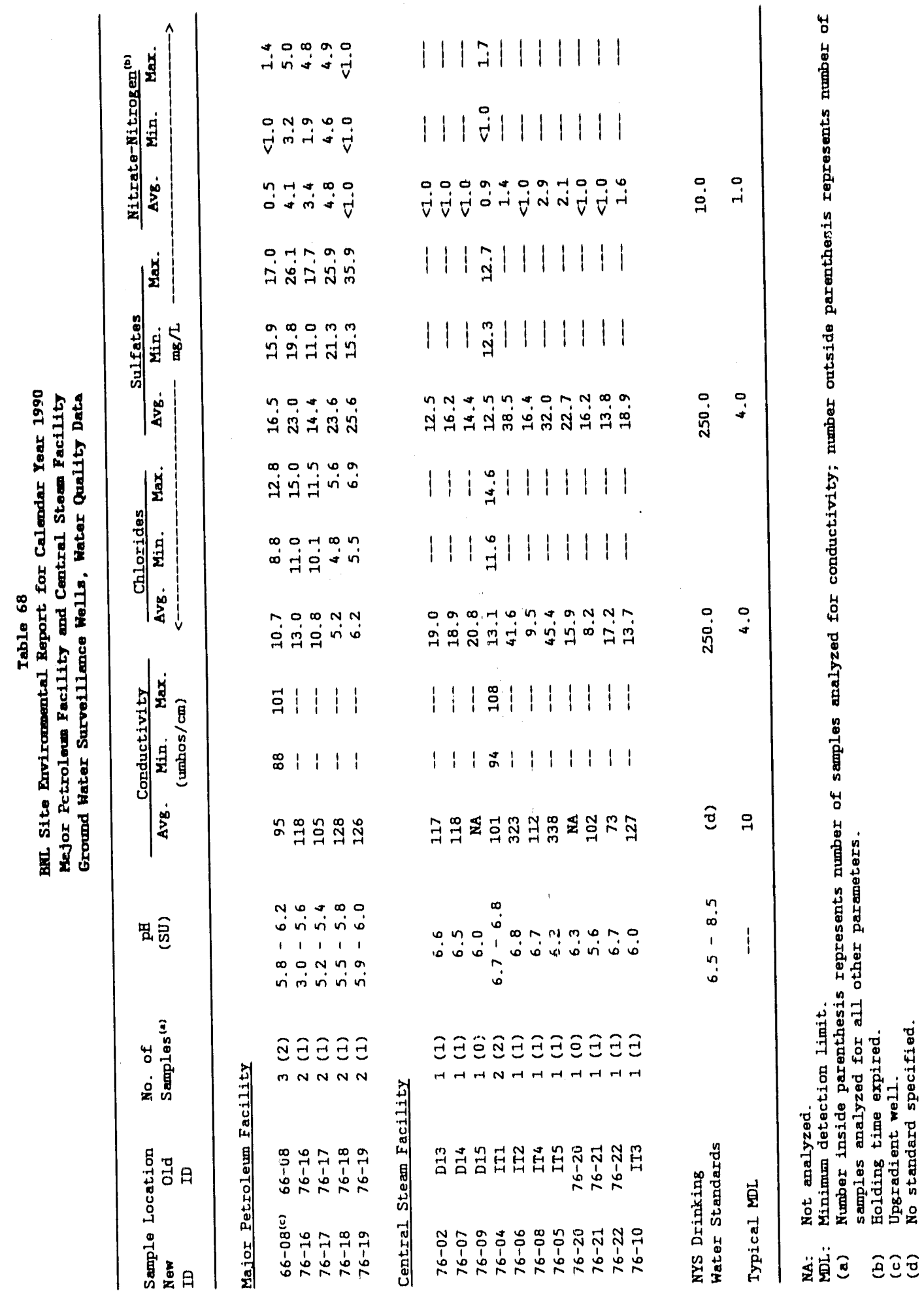




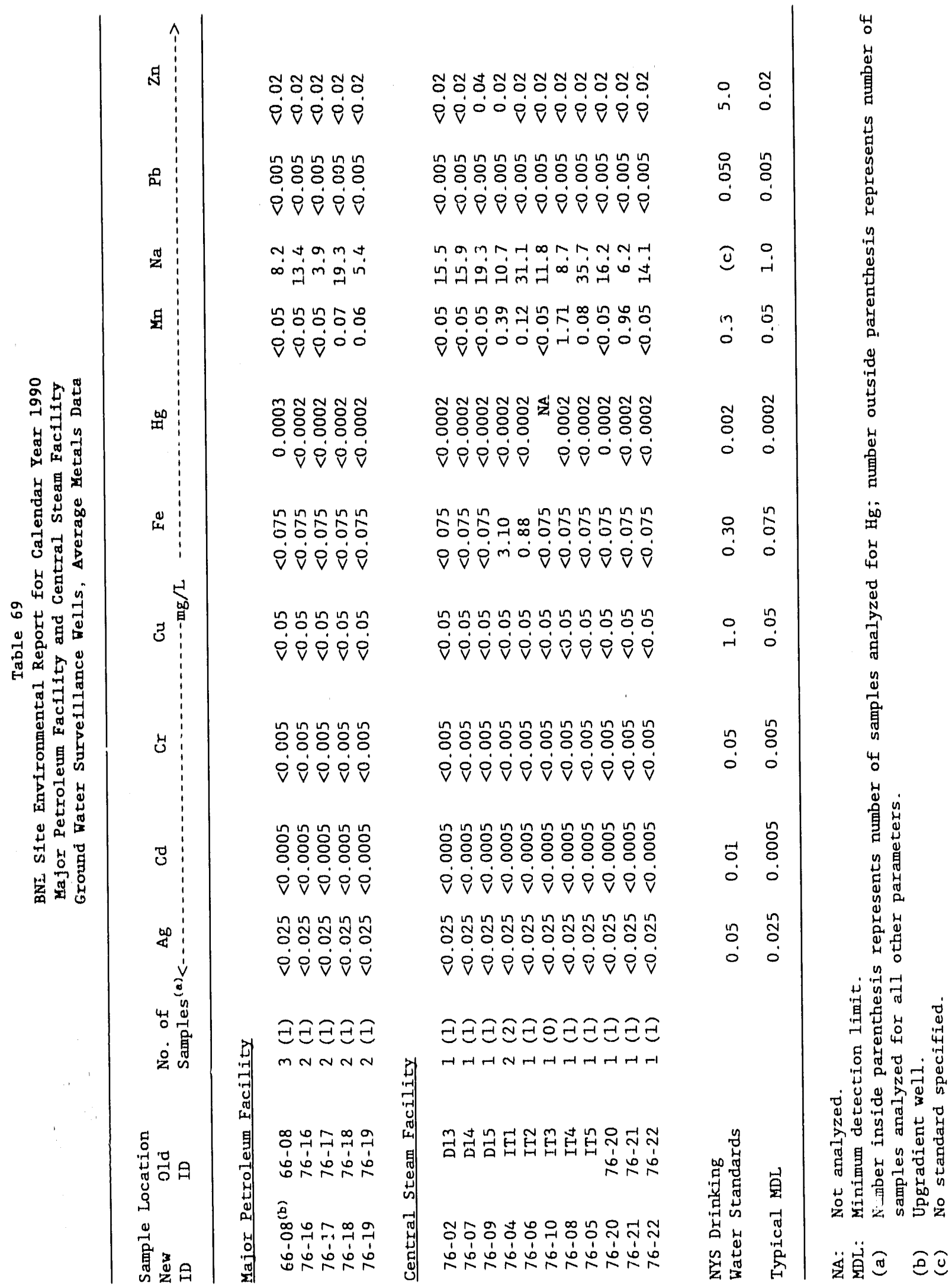




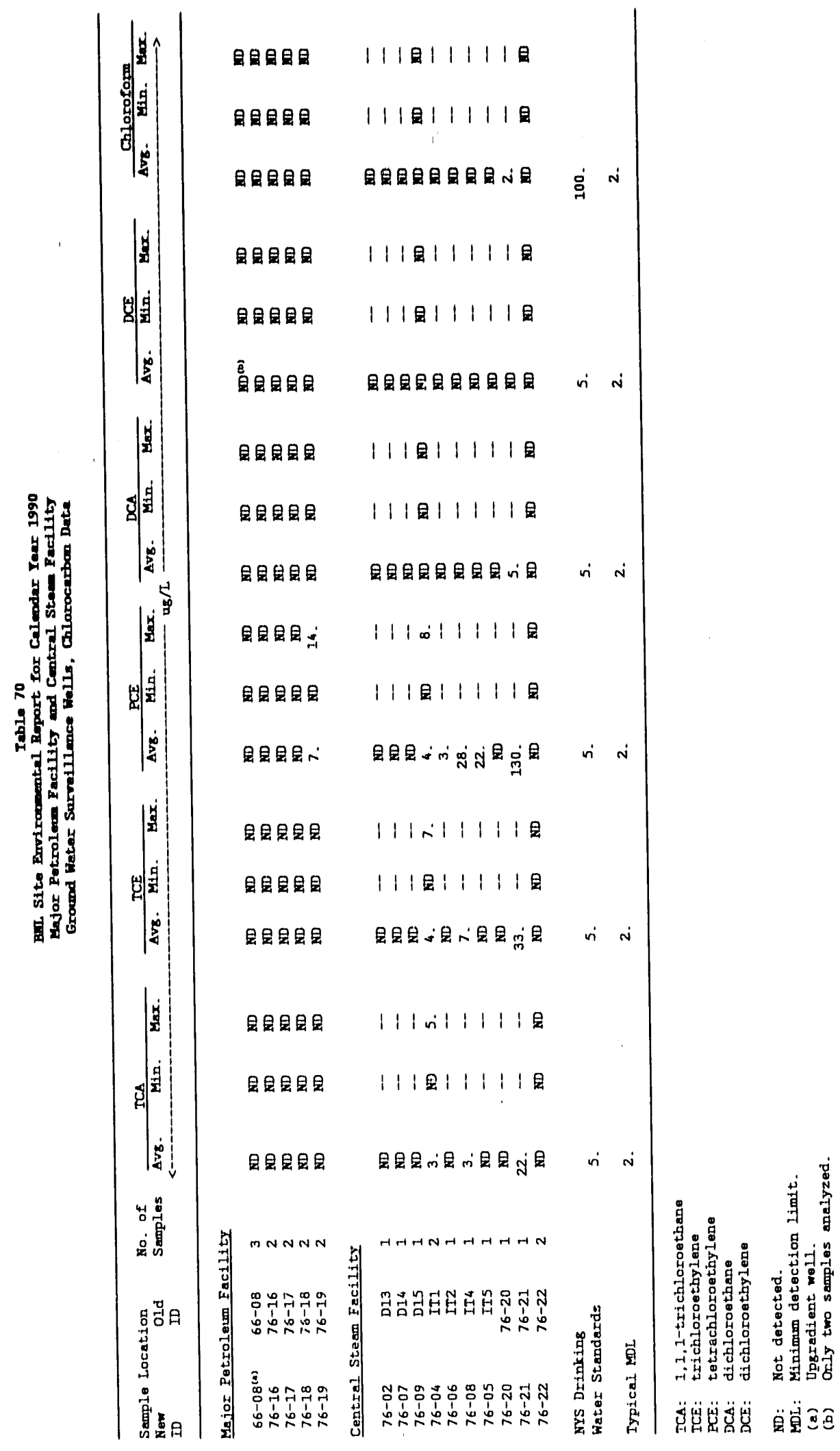




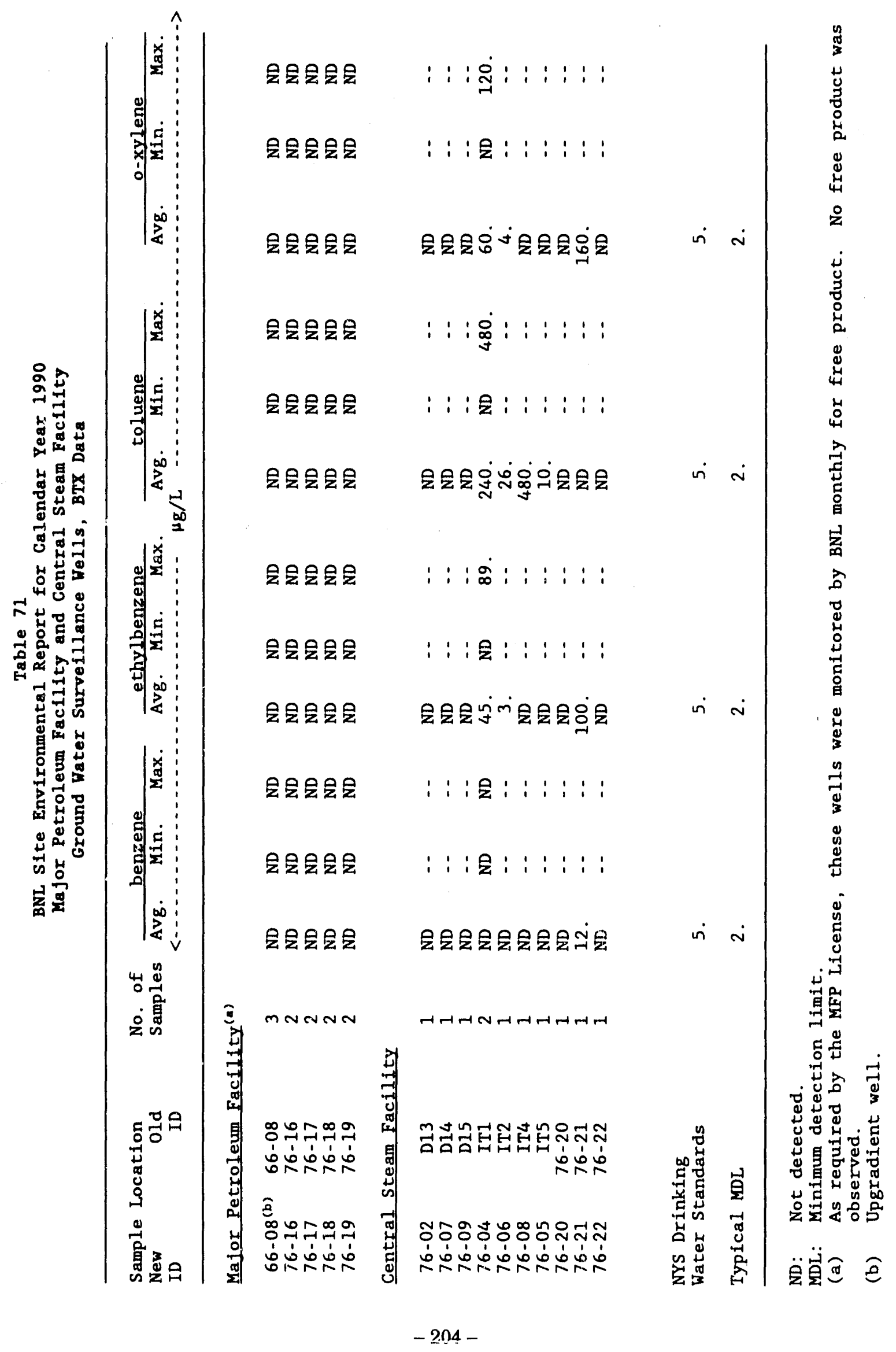




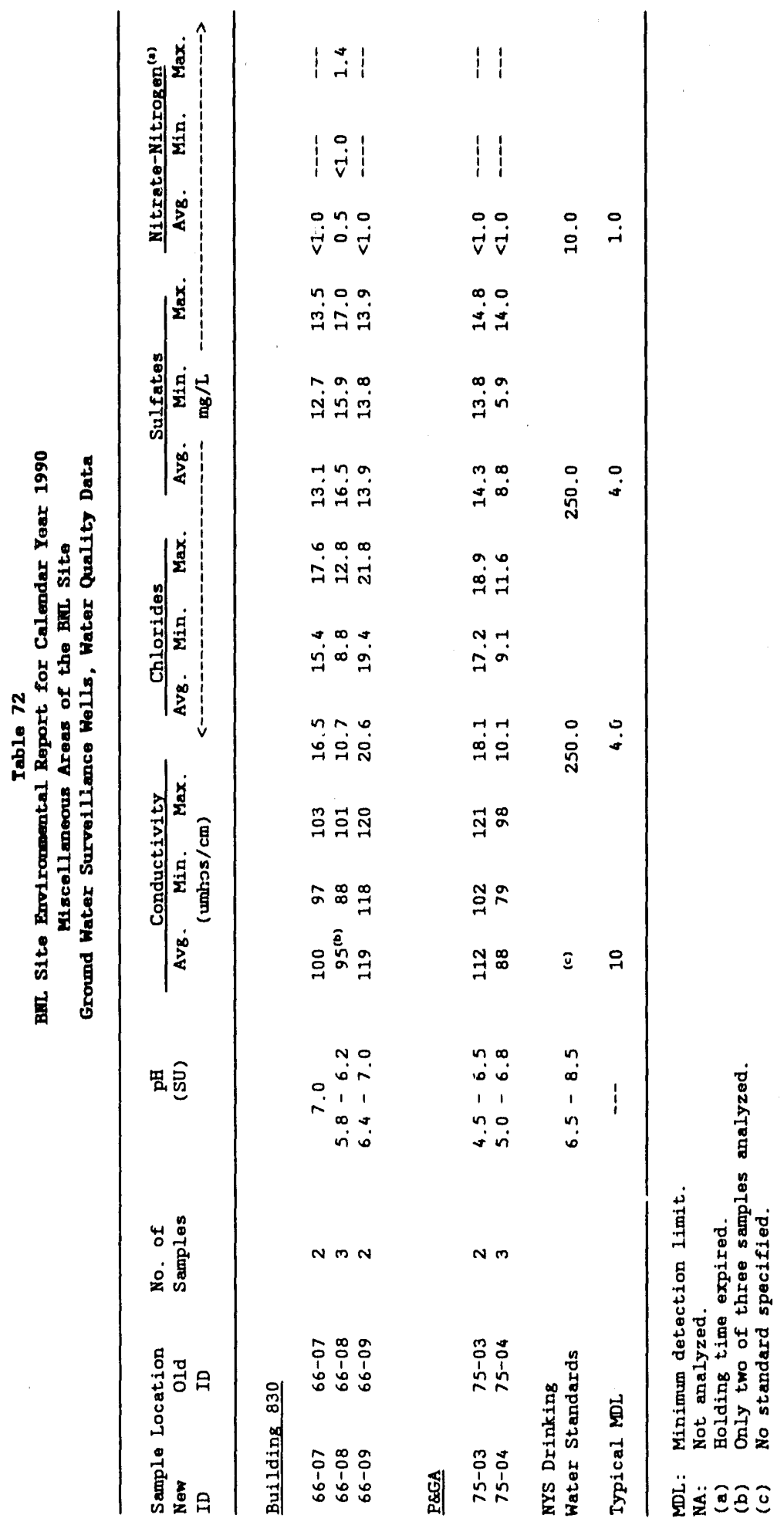




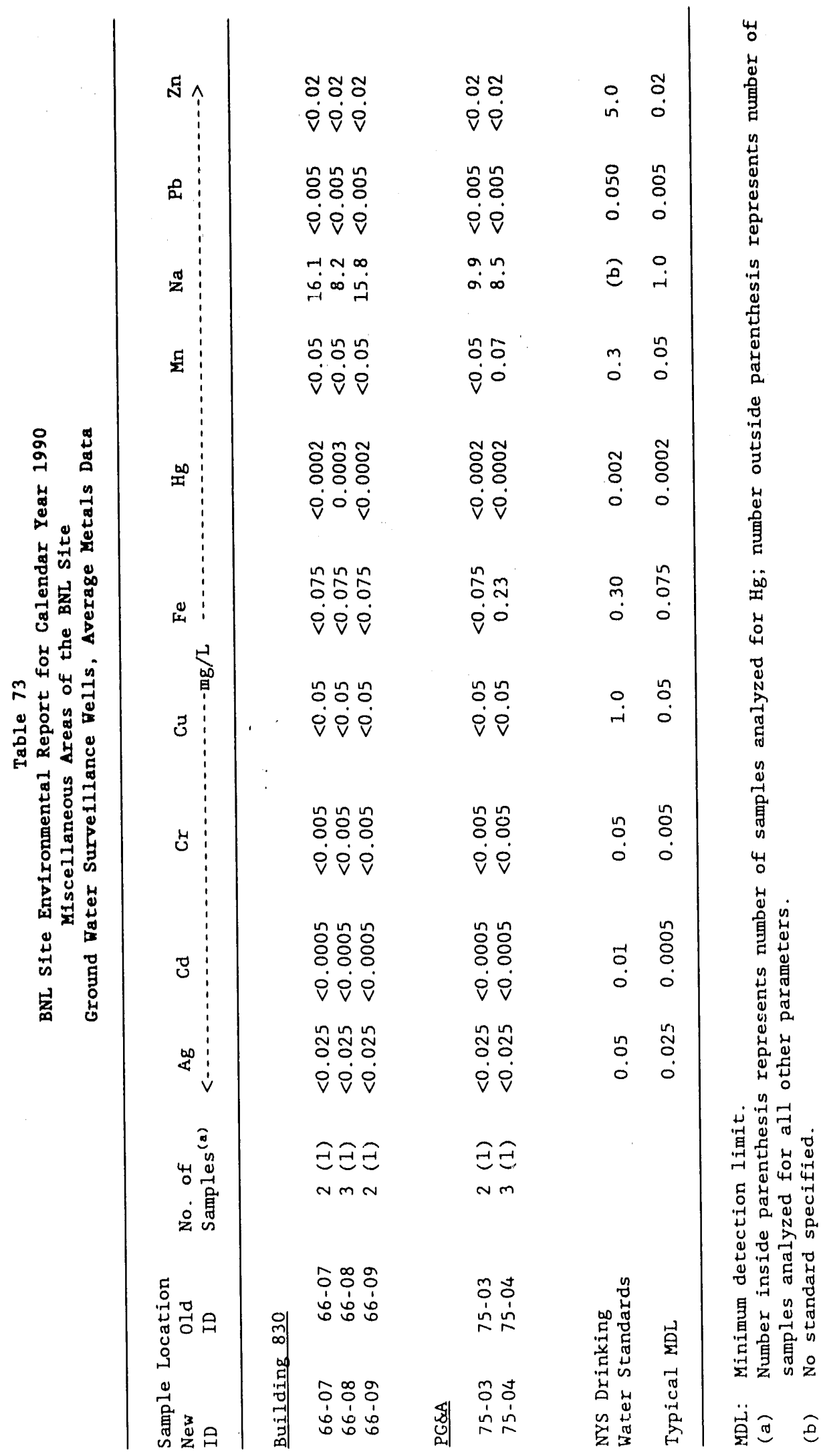




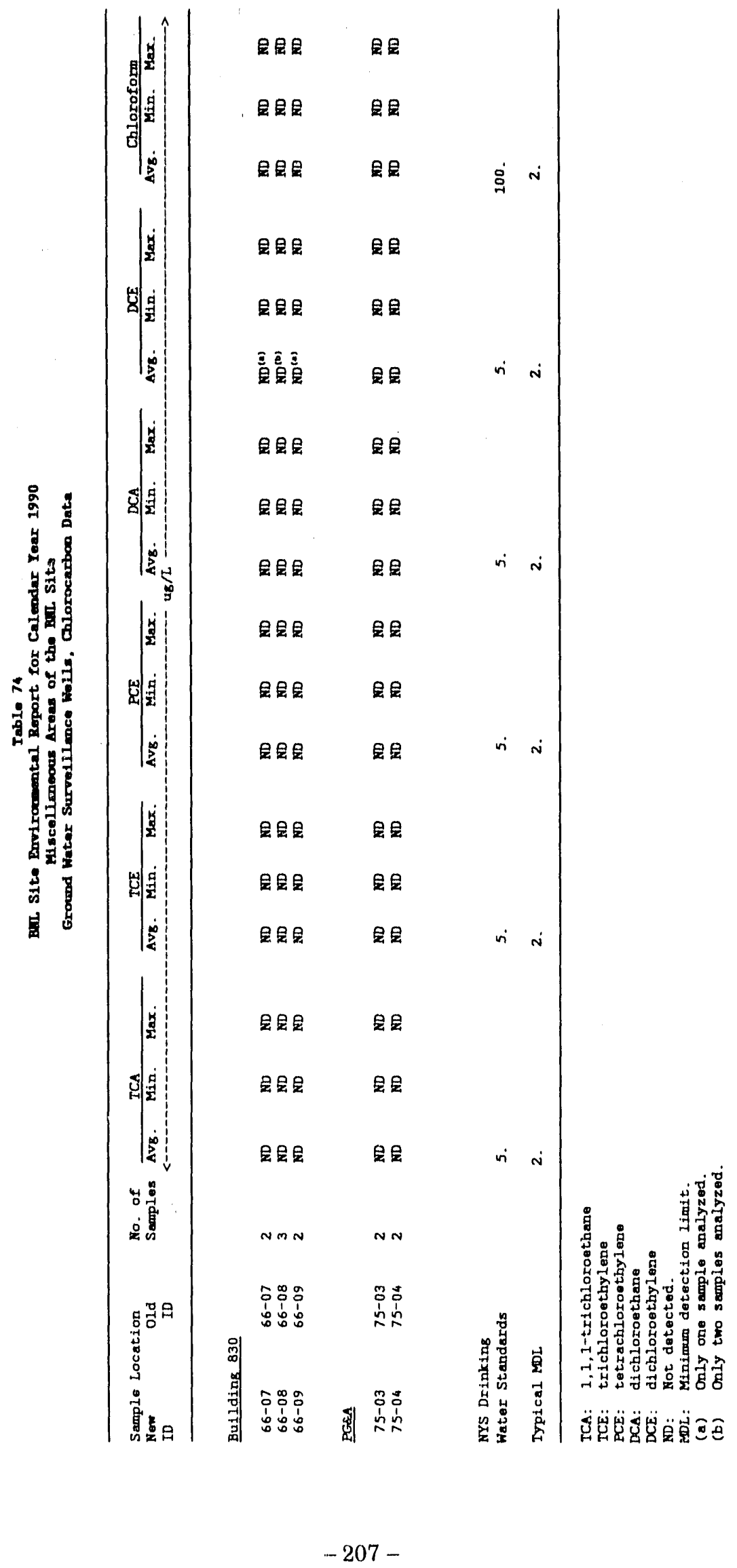




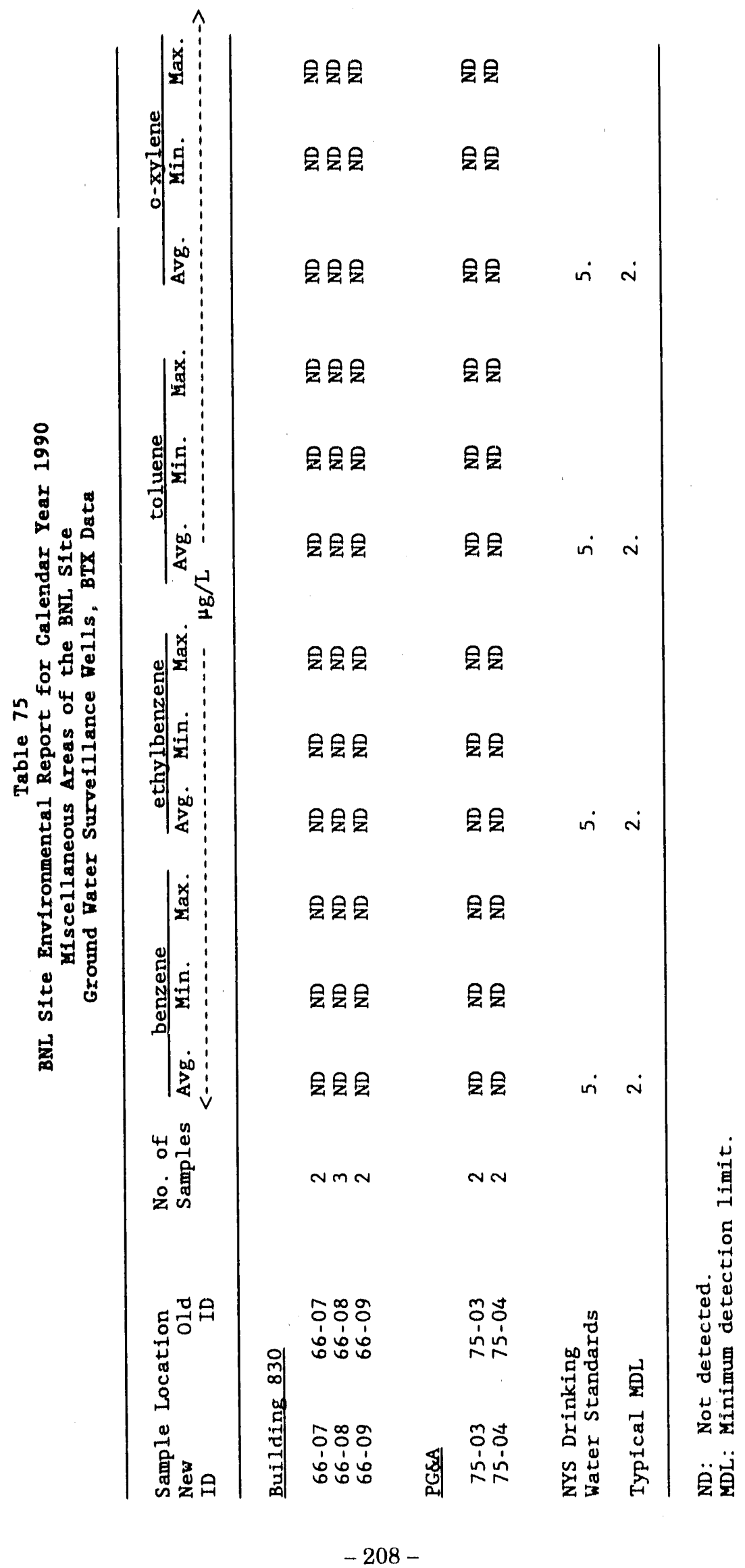




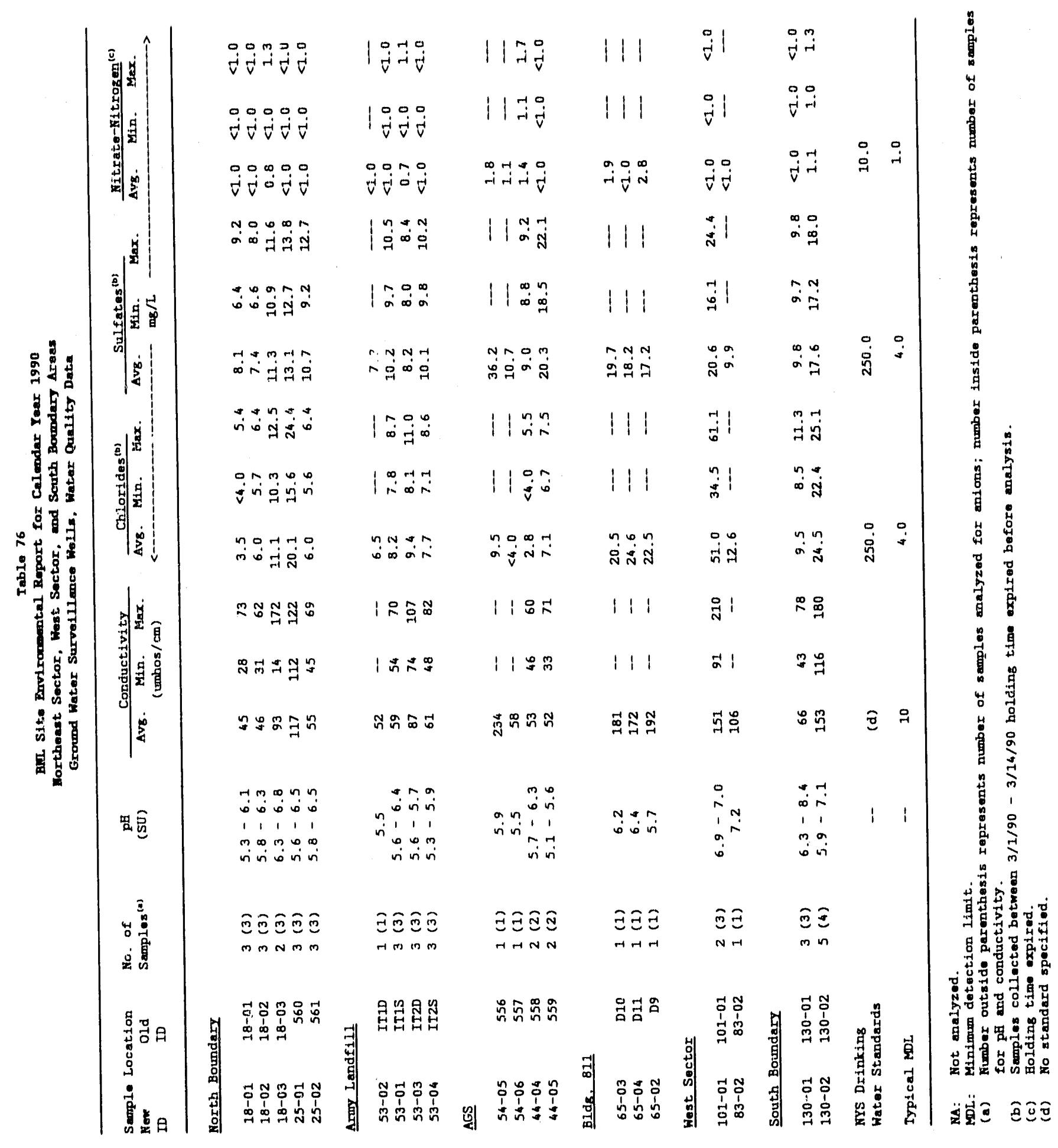




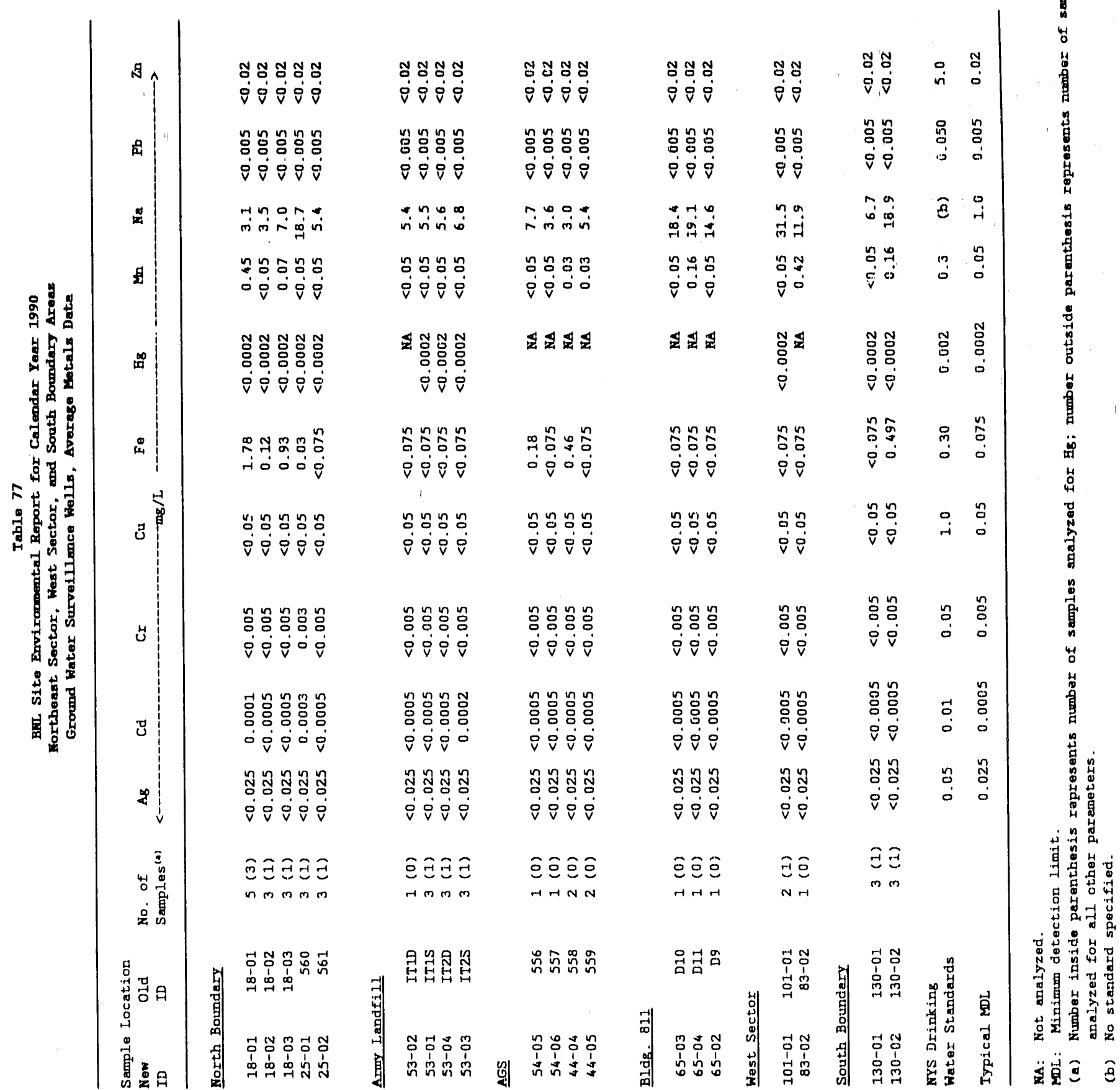




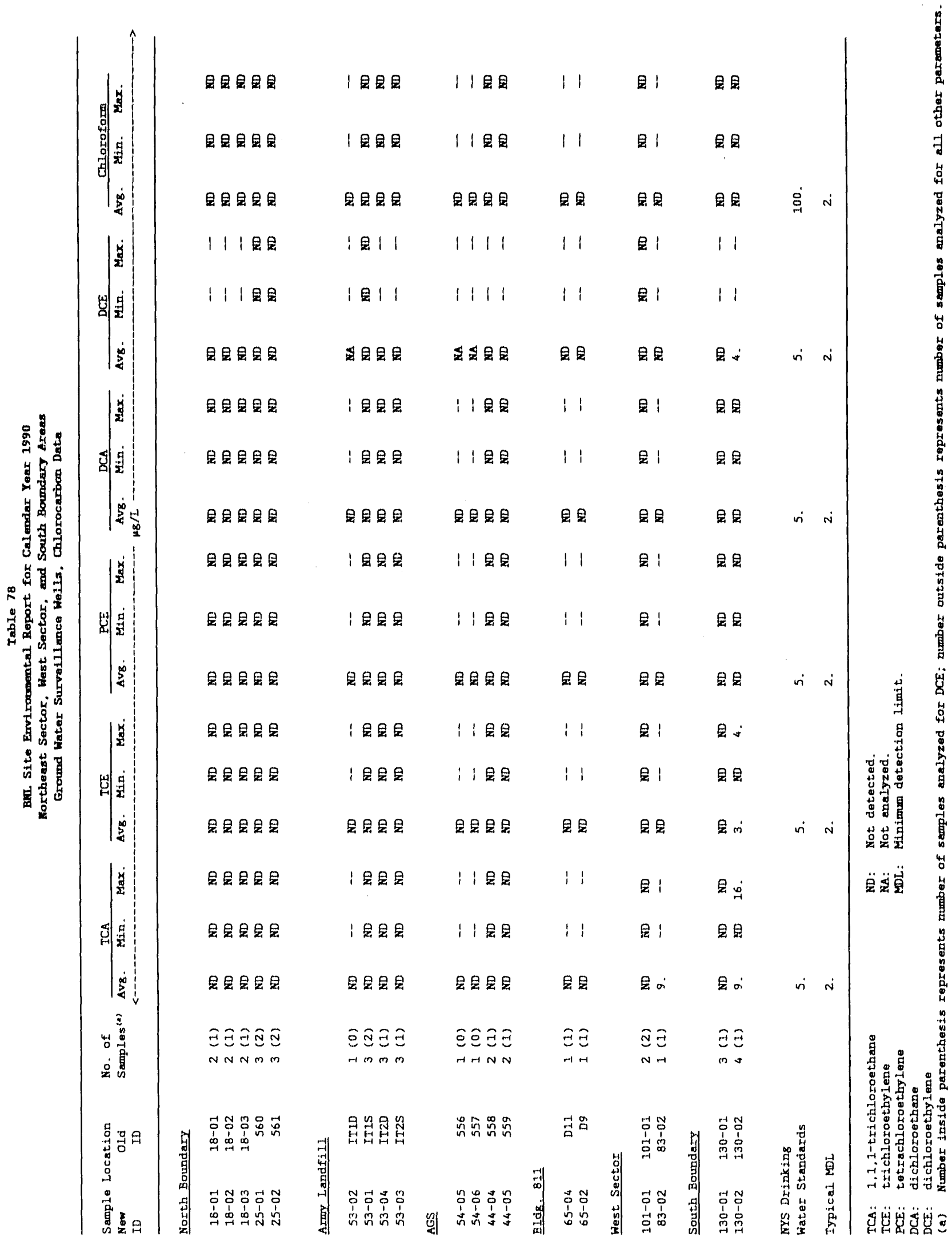




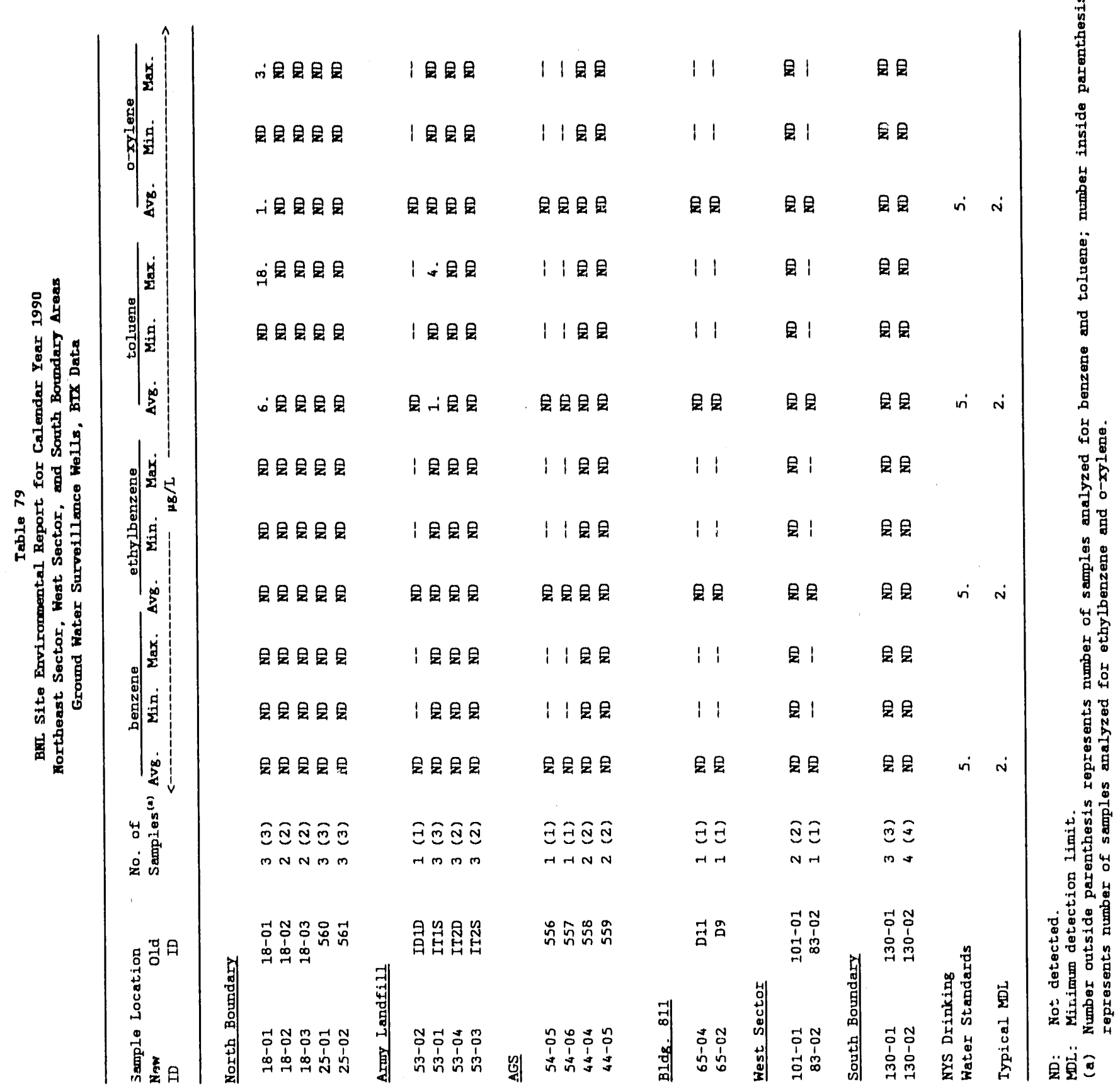


Table 80

BNL Site Environmental Report For Calendar Year 1990

Tritium Committed Effective Dose Equivalent

at the Site Boundary Monftoring Stations

\begin{tabular}{llll}
\hline $\begin{array}{l}\text { Location } \\
\text { ID }\end{array}$ & $\begin{array}{l}\text { Sector } \\
\text { ID }\end{array}$ & $\begin{array}{l}\text { Annual } \\
\text { Average } \\
\text { Air Conc } \\
\text { (pCi/m3) }\end{array}$ & $\begin{array}{l}\text { Committed } \\
\text { Effective } \\
\text { Dose } \\
\text { Equivalent } \\
\text { (mrem)(a) }\end{array}$ \\
\hline IT & N & NM & NM \\
$2 \mathrm{~T}$ & NNE & 2.5 & 0.0020 \\
$3 \mathrm{~T}$ & NE & 2.8 & 0.0022 \\
$4 \mathrm{~T}$ & ENE & 3.5 & 0.0028 \\
$5 \mathrm{~T}$ & E & 3.2 & 0.0025 \\
$6 \mathrm{~T}$ & ESE & 3.0 & 0.0024 \\
$7 \mathrm{~T}$ & SE & 0.5 & 0.0004 \\
$8 \mathrm{~T}$ & SSE & 4.3 & 0.0034 \\
$9 \mathrm{~T}$ & S & 5.1 & 0.0040 \\
$10 \mathrm{~T}$ & SSW & 3.3 & 0.0026 \\
$11 \mathrm{~T}$ & SW & 3.1 & 0.0024 \\
$12 \mathrm{~T}$ & WSW & 2.6 & 0.0020 \\
$13 \mathrm{~T}$ & W & 1.8 & 0.0014 \\
$14 \mathrm{~T}$ & WNW & 2.0 & 0.0016 \\
$15 \mathrm{~T}$ & NW & 2.0 & 0.0016 \\
$16 \mathrm{~T}$ & NNW & 7.9 & 0.0062 \\
$20 \mathrm{~T}$ & Central Site & 8.7 & 0.0068 \\
& & & \\
\hline
\end{tabular}

(a) Committed Effective Dose Equivalent includes the contribution from the inhalation and submersion pathways. ICRP Publication No. 30 dose conversion factors used.

NM: Not measured due to vandalism

Maximum Site Perimeter Dose is: $0.0068 \mathrm{mrem}$ 
Table 81

BNL S1te Environmental Report for Calendar Year 1990

Site Boundary Tritium Committed Effective Dose Equivalent

Calculated and Measured Values

\begin{tabular}{|c|c|c|}
\hline Direction & $\begin{array}{l}\text { CAP88 } \\
\text { Calculations } \\
\text { All Sources } \\
\text { mrem }\end{array}$ & $\begin{array}{l}\text { Measured } \\
\text { Committed } \\
\text { Effective } \\
\text { Dose } \\
\text { Equivalent } \\
\text { mrem (a) }\end{array}$ \\
\hline $\mathrm{N}$ & 0.0004 & NM \\
\hline NNE & 0.0004 & 0.0020 \\
\hline $\mathrm{NE}$ & 0.0004 & 0.0022 \\
\hline ENE & 0.0004 & 0.0028 \\
\hline$E$ & 0.0005 & 0.0025 \\
\hline ESE & 0.0006 & 0.0024 \\
\hline SE & 0.0007 & 0.0004 \\
\hline SSE & 0.0005 & 0.0034 \\
\hline$S$ & 0.0004 & 0.0040 \\
\hline SSW & 0.0002 & 0.0026 \\
\hline SW & 0.0002 & 0.0024 \\
\hline WSW & 0.0002 & 0.0020 \\
\hline$W$ & 0.0001 & 0.0014 \\
\hline WNW & 0.0001 & 0.0016 \\
\hline NW & 0.0002 & 0.0016 \\
\hline NNW & 0.0003 & 0.0062 \\
\hline
\end{tabular}

(a) Committed Effective Dose Equivalent includes the contribution from the inhalation and submersion pathways. ICRP Publication No. 30 dose conversion factors used.

NM: Not measured due to vanadalism. 
Table 82

BNL SIte Environinental Report for Calendar Year 1990

External Exposure Rates at the Site from Argon-41 and Oxygen

\begin{tabular}{llll}
\hline Direction & $\begin{array}{l}\text { Ar-41 } \\
\text { mrem }\end{array}$ & $\begin{array}{c}0.15 \\
\text { mrem }\end{array}$ & $\begin{array}{c}\text { Total } \\
\text { mrom }\end{array}$ \\
\hline N & 0.026 & 0.002 & 0.028 \\
NNE & 0.062 & 0.004 & 0.066 \\
NE & 0.033 & 0.002 & 0.035 \\
ENE & 0.017 & 0.001 & 0.017 \\
E & 0.020 & 0.001 & 0.021 \\
ESE & 0.025 & 0.003 & 0.029 \\
SE & 0.023 & 0.002 & 0.025 \\
SSE & 0.023 & 0.001 & 0.024 \\
S & 0.021 & 0.001 & 0.022 \\
SSW & 0.015 & 0.000 & 0.015 \\
SW & 0.024 & 0.000 & 0.024 \\
WSW & 0.013 & 0.001 & 0.014 \\
W & 0.013 & 0.001 & 0.013 \\
WNW & 0.011 & 0.001 & 0.012 \\
NW & 0.015 & 0.003 & 0.018 \\
NNW & 0.015 & 0.001 & 0.016 \\
& & & \\
\hline
\end{tabular}


Tabla 83

BNL site Environmental Report For Calendar Year 1990 Collect1ve Dose - BNL 1990 Alrborne Em1ssions

\begin{tabular}{|c|c|c|c|}
\hline Nuclide & $\begin{array}{l}\text { Major } \\
\text { Fac11ity }\end{array}$ & Dept. & $\begin{array}{l}\text { CAP8 } 8 \\
\text { Total Body } \\
\text { Dose } \\
\text { person-rem }\end{array}$ \\
\hline Ar -41 & BMRR & Reactor & $1.30 \mathrm{E}+00$ \\
\hline $\mathrm{H}-3$ & BLIP & Medical & $1.17 \mathrm{E}-02$ \\
\hline$G a-68$ & Hot Lab & Medical & $8.10 \mathrm{E}-03$ \\
\hline $\mathrm{H}-3$ & HFBR & Reactor & $4.11 \mathrm{E} .03$ \\
\hline $\mathrm{H}-3$ & VdG & DAS & $2.43 E-03$ \\
\hline $\mathrm{Br}-77$ & Hot Lab & Medical & $1.10 \mathrm{E}-03$ \\
\hline$I-126$ & Hot Lab & Medical & $1.86 \mathrm{E}-04$ \\
\hline Co- 57 & HWM & S\&EP & $1.77 E-04$ \\
\hline $\mathrm{Sa}-75$ & Hot Lab & Medical & 1. $32 E-04$ \\
\hline $\mathrm{Br}-82$ & - Hot Lab & Medical & $1.16 \mathrm{E}-04$ \\
\hline As -74 & Hot Lab & Medical & $1.13 \mathrm{E}-04$ \\
\hline I -124 & Hot Lab & Medical & $4.82 \mathrm{E}-05$ \\
\hline 0.15 & BLIP & Medical & $2.96 \mathrm{E}-05$ \\
\hline $\mathrm{Sn}-113 \mathrm{~m}$ & HWM & S\&EP & $2.69 \mathrm{E}-05$ \\
\hline $\mathrm{Be}-7$ & BLIP & Medical & $2.20 \mathrm{E}-05$ \\
\hline$I-125$ & HWM & S\&EP & 1. 33E-05 \\
\hline Co -60 & Hot Lab & Medical & $1.33 E-05$ \\
\hline $\mathrm{Hg}-203$ & Hot Lab & Medical & 1. 14E-05 \\
\hline $\mathrm{Ge}-69$ & Hot Lab & Medical & $6.16 \mathrm{E}-06$ \\
\hline $\mathrm{Eu}-155$ & Hot Lab & Medical & $6.00 \mathrm{E}-06$ \\
\hline $\mathrm{H}-3$ & Chemistry & Chemistry & $5.43 E-06$ \\
\hline $\mathrm{Cs}-137$ & Hot Lab & Medical & $5.32 \mathrm{E}-06$ \\
\hline Cs -137 & HFBR & Reactor & $5.32 E-06$ \\
\hline $\mathrm{Cs}-1.37$ & Hot Lab & Medical & $5.32 E-06$ \\
\hline$M n-54$ & Hot Lab & Medical & $5.04 E-06$ \\
\hline Cs -137 & BLIP & Medical & $4.50 E-06$ \\
\hline $\mathrm{H}-3$ & HWM & $S \& E P$ & $3.63 E-06$ \\
\hline $\mathrm{Sb}-124$ & Hot Lab & Medical & $3.57 \mathrm{E}-06$ \\
\hline$C-1.4$ & HWM & $\mathrm{S} \& E \mathrm{P}$ & $2.96 \mathrm{E}-06$ \\
\hline$Z n-65$ & Hot Lab & Medical & $2.43 E-06$ \\
\hline As -74 & BLIP & Medical & $2.20 \mathrm{E}-06$ \\
\hline$M n-54$ & BLIP & Medical & $1.97 \mathrm{E}-06$ \\
\hline As -72 & BLIP & Medical & $1.64 \mathrm{E}-06$ \\
\hline $\mathrm{Na}-24$ & BLIP & Medical & 5. 71E-07 \\
\hline $\mathrm{Sn}-117 \mathrm{~m}$ & HWM & S\&EP & $2.17 \mathrm{E}-07$ \\
\hline $\mathrm{Xe}-127$ & Hot Lab & Medical & $1.16 \mathrm{E}-07$ \\
\hline Sc -46 & HFBR & Reactor & $1.16 \mathrm{E}-07$ \\
\hline $\mathrm{Xe}-127$ & Hot Lab & Medical & $1.16 \mathrm{E}-07$ \\
\hline$X e-125$ & BLIP & Medical & $7.13 \mathrm{E}-08$ \\
\hline $\mathrm{Cr}-51$ & HWM & $\mathrm{S} \& \mathrm{EP}$ & $2.31 E-08$ \\
\hline $\mathrm{Be}-7$ & HFBR & Reactor & $1.48 \mathrm{E}-08$ \\
\hline $\mathrm{T} 1-201$ & HWM & $\mathrm{S} \& \mathrm{EP}$ & $1.12 \mathrm{E}-08$ \\
\hline Total & & & 1. $33 \mathrm{E}+00$ \\
\hline
\end{tabular}


Table 84

BNL S1te Environmental Report for Calendar Year 1990

Collective and Maximum Individual Committed Effective Dose

Equivalent (CEDE) from the Water Pathway

\begin{tabular}{|c|c|c|c|}
\hline Pathway & Nuclide & $\begin{array}{l}\text { Maximum } \\
\text { Individual } \\
\text { CEDE (mrem) }\end{array}$ & $\begin{array}{l}\text { Collective } \\
\text { CEDE } \\
\text { (person-mrem) }\end{array}$ \\
\hline $\begin{array}{l}\text { Drinking } \\
\text { Water }\end{array}$ & $\mathrm{H}-3$ & 0.104 & 52 \\
\hline Fish & $\begin{array}{l}\text { Cs }-137 \\
\operatorname{Sr}-90^{(a)}\end{array}$ & $\begin{array}{l}0.080 \\
0.670\end{array}$ & $\begin{array}{r}40 \\
335\end{array}$ \\
\hline $\begin{array}{l}\text { Al1 Ingestion } \\
\text { Pathways }\end{array}$ & & 0.854 & 427 \\
\hline
\end{tabular}

(a) Sr-90 CEDE estimated from $1990 \mathrm{Cs}$ data and a ratio of 1989 Sr: Cs values. 
Table 85

BNL Site Environmental Report for Calendar Year 1990 Collective Dose from All Pathways

\begin{tabular}{|c|c|c|c|c|c|}
\hline Pathway & $\begin{array}{l}\text { Maximum } \\
\text { Individual } \\
\text { CEDE } \\
\text { (mrem) }\end{array}$ & $\begin{array}{l}\text { Annual } \\
\text { Background } \\
\text { Dose Fquiv. } \\
\text { (mrem) }\end{array}$ & $\begin{array}{l}\text { Maximum } \\
\text { Individual } \\
\text { Annual Dose } \\
\text { Limit (mrem) }\end{array}$ & $\begin{array}{l}\text { Collective } \\
\text { CEDE } \\
\text { (person-mrem) }\end{array}$ & $\begin{array}{l}\text { Collective } \\
\text { Background } \\
\text { Dose Equiv. } \\
\text { (person-mrem) }\end{array}$ \\
\hline $\operatorname{Air}(a)$ & 0.067 & 58 & 10 & 1330 & $2.91 E+08$ \\
\hline Water & 0.104 & ND & 4 & 52 & ND \\
\hline Fish & 0.750 & 0.206 & NA & 375 & 103 \\
\hline $\begin{array}{l}\text { All } \\
\text { Pathways }\end{array}$ & 0.921 & 58 & 100 & 1757 & $2.91 \mathrm{E}+08$ \\
\hline
\end{tabular}

ND: Not detected.

NA: Not applicable.

(a) Direct exposure from plume passage included in air component. 


\section{APPENDIX E}

Table 1

BNL Quality Assessment Program Results Environmental Measurements Laboratory

\begin{tabular}{|c|c|c|c|c|c|}
\hline Isotope & Matrix & Units & Date & $\begin{array}{l}\text { Conc. } \\
\text { Leve1 }\end{array}$ & $\begin{array}{l}\text { BNL/EML } \\
\text { Ratio }\end{array}$ \\
\hline $\mathrm{H}^{3}$ & Water & $\mathrm{Bq} \cdot \mathrm{l}^{-1}$ & $\begin{array}{l}? / 90 \\
9 / 90\end{array}$ & $\begin{array}{l}1960 \\
3900\end{array}$ & $\begin{array}{l}.87 \\
.93\end{array}$ \\
\hline $\mathrm{Mn}^{54}$ & Water & & $\begin{array}{l}3 / 90 \\
9 / 90\end{array}$ & $\begin{array}{l}103 \\
301\end{array}$ & $\begin{array}{l}1.03 \\
1.09\end{array}$ \\
\hline $\mathrm{Co}^{57}$ & Water & & $\begin{array}{l}3 / 90 \\
9 / 90\end{array}$ & $\begin{array}{r}198 \\
1300\end{array}$ & $\begin{array}{r}1.02 \\
.40^{\mathrm{a}}\end{array}$ \\
\hline $\mathrm{Co}^{60}$ & Water & & $\begin{array}{l}3 / 90 \\
9 / 90\end{array}$ & $\begin{array}{l}206 \\
491\end{array}$ & $\begin{array}{r}.93 \\
1.13\end{array}$ \\
\hline $\mathrm{Cs}^{134}$ & Water & & $\begin{array}{l}3 / 90 \\
9 / 90\end{array}$ & $\begin{array}{l}462 \\
355\end{array}$ & $\begin{array}{r}.94 \\
1.16\end{array}$ \\
\hline $\mathrm{Cs}^{137}$ & Water & & $\begin{array}{l}3 / 90 \\
9 / 90\end{array}$ & $\begin{array}{l}198 \\
390\end{array}$ & $\begin{array}{l}1.01 \\
1.16\end{array}$ \\
\hline $\mathrm{Ce}^{144}$ & Water & & $\begin{array}{l}3 / 90 \\
9 / 90\end{array}$ & $\begin{array}{l}403 \\
923\end{array}$ & $\begin{array}{l}1.16 \\
1.06\end{array}$ \\
\hline
\end{tabular}

\begin{tabular}{|c|c|c|c|c|c|}
\hline $\mathrm{Mn}^{54}$ & Air & $\begin{array}{l}\mathrm{Bq} / \\
\text { Filter }\end{array}$ & $\begin{array}{l}3 / 90 \\
9 / 90\end{array}$ & $\begin{array}{r}9.6 \\
33.3\end{array}$ & $\begin{array}{l}1.03 \\
1.15\end{array}$ \\
\hline $\mathrm{Co}^{57}$ & Air & & $\begin{array}{l}3 / 90 \\
9 / 90\end{array}$ & $\begin{array}{r}6.5 \\
11.4\end{array}$ & $\begin{array}{r}.89 \\
1.08\end{array}$ \\
\hline $\mathrm{Co}^{60}$ & Air & & $\begin{array}{l}3 / 90 \\
9 / 90\end{array}$ & $\begin{array}{r}9.4 \\
25.4\end{array}$ & $\begin{array}{l}.95 \\
.98\end{array}$ \\
\hline $\mathrm{Cs}^{134}$ & Air & & $\begin{array}{l}3 / 90 \\
9 / 90\end{array}$ & $\begin{array}{l}18.2 \\
16.3\end{array}$ & $\begin{array}{l}.83 \\
.97\end{array}$ \\
\hline $\mathrm{Cs}^{137}$ & Air & & $\begin{array}{l}3 / 90 \\
9 / 90\end{array}$ & $\begin{array}{l}20.4 \\
15.7\end{array}$ & $\begin{array}{r}.94 \\
1.01\end{array}$ \\
\hline $\mathrm{Ce}^{144}$ & Air & & $\begin{array}{l}3 / 90 \\
9 / 90\end{array}$ & $\begin{array}{l}31.2 \\
16.5\end{array}$ & $\begin{array}{r}.91 \\
1.03\end{array}$ \\
\hline $\mathrm{Be}^{7}$ & Air & & $3 / 90$ & 51.4 & 1.03 \\
\hline $\mathrm{Cs}^{137}$ & Veg & $\mathrm{Bq} \bullet \mathrm{kg}^{-1}$ & $\begin{array}{l}3 / 90 \\
9 / 90\end{array}$ & $\begin{array}{l}28.5 \\
18.2\end{array}$ & $\begin{array}{l}.81 \\
.79\end{array}$ \\
\hline$K^{40}$ & Veg & & $\begin{array}{l}3 / 90 \\
9 / 90\end{array}$ & $\begin{array}{r}323 \\
1030\end{array}$ & $\begin{array}{l}.69 \\
.81\end{array}$ \\
\hline $\mathrm{Cs}^{137}$ & Soil & $\mathrm{Bq} \bullet \mathrm{kg}^{-1}$ & $\begin{array}{l}3 / 90 \\
9 / 90\end{array}$ & $\begin{array}{r}17500 \\
196\end{array}$ & $\begin{array}{l}.70 \\
.81\end{array}$ \\
\hline$k^{40}$ & Soil & & $\begin{array}{l}3 / 90 \\
9 / 90\end{array}$ & $\begin{array}{l}608 \\
513\end{array}$ & $\begin{array}{l}.74 \\
.84\end{array}$ \\
\hline
\end{tabular}

a Outside acceptance limits, $>50 \%$ 
Table 2

BNL Intercomparison study Results

Environmental Monitoring Systems Laboratory

\begin{tabular}{|c|c|c|c|c|c|}
\hline Isotope & Matrix & Units & Date & $\begin{array}{l}\text { Conc. } \\
\text { Leve } 1\end{array}$ & $\begin{array}{l}\text { BNL/EMSL } \\
\text { Rat1o }\end{array}$ \\
\hline $\begin{array}{l}\text { Gross } \\
\text { Alpha }\end{array}$ & Water & $\mathrm{pCi} \bullet \ell^{-1}$ & $\begin{array}{l}1 / 90 \\
9 / 90 \\
10 / 90\end{array}$ & $\begin{array}{l}12 \\
10 \\
62\end{array}$ & $\begin{array}{l}.41 \\
.50 \\
.81\end{array}$ \\
\hline $\begin{array}{l}\text { Gross } \\
\text { Beta }\end{array}$ & Water & & $\begin{array}{l}1 / 90 \\
9 / 90 \\
10 / 90\end{array}$ & $\begin{array}{r}12 \\
10 \\
53\end{array}$ & $\begin{array}{l}.86 \\
.80 \\
.94\end{array}$ \\
\hline $\mathrm{H}^{3}$ & Water & & $\begin{array}{l}2 / 90 \\
6 / 90\end{array}$ & $\begin{array}{l}4976 \\
2933\end{array}$ & $\begin{array}{r}.95 \\
1.11\end{array}$ \\
\hline $\mathrm{Co}^{60}$ & Water & & $6 / 90$ & 24 & $1.40^{\mathrm{a}}$ \\
\hline $\mathrm{Cs}^{134}$ & Water & & $4 / 90$ & 15 & 1.18 \\
\hline $\operatorname{CS}^{137}$ & Water & & $\begin{array}{l}4 / 90 \\
6 / 90 \\
10 / 90\end{array}$ & $\begin{array}{r}15 \\
25 \\
5\end{array}$ & $\begin{array}{l}1.29 \\
1.29 \\
3.40^{b}\end{array}$ \\
\hline $\mathrm{Zn}^{65}$ & Water & & $6 / 90$ & 148 & $1.27^{a}$ \\
\hline $\mathrm{Ba}^{133}$ & Water & & $6 / 90$ & 99 & 1.00 \\
\hline Alpha & Air & $\begin{array}{l}\text { pCi/ } \\
\text { Filter }\end{array}$ & $3 / 90$ & 5 & 1.20 \\
\hline Beta & & & $3 / 90$ & 31 & 1.09 \\
\hline$I^{131}$ & Milk & $\mathrm{pCi} \bullet \ell^{-1}$ & $4 / 90$ & 99 & 1.12 \\
\hline $\mathrm{Cs}^{137}$ & & & $4 / 90$ & 24 & 1.36 \\
\hline $\mathrm{K}$ & & $\mathrm{mg} / \mathrm{l}$ & $4 / 90$ & 1550 & 1.16 \\
\hline
\end{tabular}

a Above control limits, \pm 3 o.

b Determined to be an outlier; s BNL MDL. 
Table 3

BNL Non-potable Water Chemistry Proficiency Test Results Environmental Laboratory Approval Program

\begin{tabular}{|c|c|c|c|}
\hline Analyte & Date & $\begin{array}{l}\text { Conc, Leve I } \\
\left(\mu g \bullet \ell^{-1}\right)\end{array}$ & $\begin{array}{l}\text { BNL/ELAP } \\
\text { Ratio }\end{array}$ \\
\hline Benzene & $7 / 90$ & $\begin{array}{l}19.0 \\
37.4\end{array}$ & $\begin{array}{l}.94 \\
.96\end{array}$ \\
\hline Ethyl-benzene & $7 / 90$ & $\begin{array}{l}12.1 \\
20.3\end{array}$ & $\begin{array}{l}.79 \\
.82\end{array}$ \\
\hline Toluene & $7 / 90$ & $\begin{array}{l}26.5 \\
35.2\end{array}$ & $\begin{array}{l}.91 \\
.95\end{array}$ \\
\hline Chloroform & $7 / 90$ & $\begin{array}{l}45.1 \\
22.5\end{array}$ & $\begin{array}{r}.97 \\
1.02\end{array}$ \\
\hline
\end{tabular}


Tablo 4

BNL Potable Water Chemistry Proficiency Test Results Environmental Laboratory Approval Program

\begin{tabular}{|c|c|c|c|}
\hline Analyte & Date & $\begin{array}{l}\text { Conc, Leve1 } \\
\left(\mu \mathrm{g} \bullet e^{-1}\right)\end{array}$ & $\begin{array}{l}\text { BNL/ELAP } \\
\text { Ratio }\end{array}$ \\
\hline Cloride & $\begin{array}{l}4 / 90 \\
10 / 90\end{array}$ & $\begin{array}{r}35.3 \\
101.0 \\
70.2 \\
40.1\end{array}$ & $\begin{array}{r}1.03 \\
1.00 \\
.95 \\
.99\end{array}$ \\
\hline Nitrate (asN) & $\begin{array}{l}4 / 90 \\
10 / 90\end{array}$ & $\begin{array}{l}1.35 \\
4.92 \\
2.00 \\
0.51\end{array}$ & $\begin{array}{r}1.01 \\
1.01 \\
.95 \\
.97\end{array}$ \\
\hline Sulfate & $\begin{array}{l}4 / 90 \\
10 / 90\end{array}$ & $\begin{array}{l}99.3 \\
49.9 \\
84.0 \\
29.8\end{array}$ & $\begin{array}{l}.98 \\
.98 \\
.96 \\
.98\end{array}$ \\
\hline Barium & $\begin{array}{l}4 / 90 \\
10 / 90\end{array}$ & $\begin{array}{l}251 \\
549 \\
300 \\
655\end{array}$ & $\begin{array}{r}.95 \\
.96 \\
1.00 \\
1.01\end{array}$ \\
\hline Cadmium & $\begin{array}{l}4 / 90 \\
10 / 90\end{array}$ & $\begin{array}{l}2.60 \\
7.21 \\
3.17 \\
8.16\end{array}$ & $\begin{array}{r}1.01 \\
.93 \\
1.05 \\
1.08\end{array}$ \\
\hline Copper & $\begin{array}{l}4 / 90 \\
1.0 / 90\end{array}$ & $\begin{array}{l}203 \\
406 \\
101 \\
664\end{array}$ & $\begin{array}{l}1.03 \\
1.01 \\
1.07 \\
1.07\end{array}$ \\
\hline Lead & $\begin{array}{l}4 / 90 \\
10 / 90\end{array}$ & $\begin{array}{l}10.2 \\
39.8 \\
15.5 \\
38.6\end{array}$ & $\begin{array}{r}1.03 \\
1.08 \\
.97 \\
1.01\end{array}$ \\
\hline Manganese & $\begin{array}{l}4 / 90 \\
10 / 90\end{array}$ & $\begin{array}{l}10.2 \\
30.2 \\
19.9 \\
39.9\end{array}$ & $\begin{array}{r}1.01 \\
.99 \\
.96 \\
.97\end{array}$ \\
\hline Silver & $\begin{array}{l}4 / 90 \\
10 / 90\end{array}$ & $\begin{array}{l}20.2 \\
45.6 \\
15.2 \\
40.6\end{array}$ & $\begin{array}{l}1.07 \\
1.04 \\
1.04 \\
1.07\end{array}$ \\
\hline Zinc & $\begin{array}{l}4 / 90 \\
10 / 90\end{array}$ & $\begin{array}{r}603 \\
1000 \\
202 \\
753\end{array}$ & $\begin{array}{r}.95 \\
.95 \\
1.07 \\
1.05\end{array}$ \\
\hline Chromium & $\begin{array}{l}4 / 90 \\
10 / 90\end{array}$ & $\begin{array}{l}25.4 \\
40.8 \\
15.6 \\
35.6\end{array}$ & $\begin{array}{r}1.09 \\
.99 \\
.97 \\
.98\end{array}$ \\
\hline Iron & $\begin{array}{l}4 / 90 \\
10 / 90\end{array}$ & $\begin{array}{c}153 \\
243 \\
81.4 \\
284\end{array}$ & $\begin{array}{r}.97 \\
.95 \\
.99 \\
1.02\end{array}$ \\
\hline Sodium & $\begin{array}{l}4 / 90 \\
10 / 90\end{array}$ & $\begin{array}{r}766 \\
1510 \\
324 \\
2220\end{array}$ & $\begin{array}{l}.99 \\
.97 \\
.93 \\
.99\end{array}$ \\
\hline
\end{tabular}




\section{APPENDIX F}

REFERENCES

1. Long Island Lighting Company Population Estimates, 1990.

2. Nagle, C. M., Climatology of Brookhaven National Laboratory: 1949-1973, BNL Report No. 50466, November, 1975.

3. Nagle, C. M., "Climatology of Brookhaven National Laboratory: 1974 through 1977." BNL-50857, May, 1978.

4. Warren, M. A., W. de Laguna, and N. J. Lusczynski, "Hydrology of Brookhaven National Laboratory and Vicinity, " Geological Survey Bulletin $1156-C, 1968$.

5. Cohen, P. H. et al, Atlas of Long Island Water Resources, New York State Resources Bulletin No, 62, 1969.

6. Clearlock, D, B. and A, F. Reisenauer, "Sitewide Ground Water Flow Studies for Brookhaven National Laboratory," BNL Informal Report, December, 1971.

7. H2M, Holzmacher, McLendon, and P. C. Murrel, in Association with Roux Associates, Aquifer Evaluation and Program Design for Restoration. Submitted to BNL, June, 1985.

8. Koppelman, L. Long Island Waste Treatment Management Plan, Vol. I and II, July, 1978 .

9. U. S. Department of Energy, "Radiation Protection of the Public and the Environment", DOE Order 5400.5, February, 1990.

10. BNL Environmental Monitoring Reports - 1971-1.987, Safety and Environmental. Protection Division, BNT, Report Nos. 17874, 18625, 19977, 21320, 22627, $50813,51031,51252,51417,51697,51827,51884,51993,52088,52152$, 52207,52264 .

11. U. S. Environmental Protection Agency, Environmental Radiation Data Report 59, July - September, 1989, EPA 520/5-90-003, March, 1990.

12. U. S. Environmental Protection Agency, Environmental Radiation Data Report 60, October - December, 1989, EPA 520/5-90-018, June, 1990.

13. U. S. Environmental Protection Agency, Environmental Radiation Data Report 61, January - March, 1990 EPA 520/5-90-031, September, 1990.

14. U. S, Environmental Protection Agency, Environmental Radiation Data Report 62, April - June, 1990, EPA 520/5-91-044, Decermber, 1990.

15. Eisenbud, M., Environmental Radioactivity, Academic Press, Inc., New York, 1987. 
16. "Tiger Team Assessment of the Brookhaven National Laboratory", U,S. Department of Energy, DOE/EH-0140, June, 1990.

17. Chapter 1 State Sanitary Code NYSDOH Part 5, Drinking Water Supplies Subpart 5-1 (Revised and adopted January 9, 1989).

18. New York State Department of Environmental Conservation, Classiffcation and Standards Governing the Quality and Purity of Waters of New York State, Parts $700-703,1978$.

19. U. S. Environmental Protection Agency, "National Interim Primary Drinking Water Regulations," 1975, Amended February 19, 1988.

20. U. S. Department of Energy, "Quality Assurance," Order No. 5700.6B, September, 1.986.

21. Brookhaven Nationa1 Laboratory, "Quality Assurance Manual, "Revised March, 1989.

22. Brookhaven National Laboratory, "Safety and Environmental Protection Quality Assurance Program Document", Revised May, 1989.

23. U.S. Depaxtment of Energy, "General Environmental Protection Program", Order 5400.1, November, 1988.

24. Personal Communications, L. Mausner, Medical Department, BNL, 1986.

25. New York State Department of Environmental Conservation, Fue1 Composition and Use, Part 225, Amended November, 1984.

26. Reliance Energy Services, "Stack Monitoring Program for Brookhaven National Laboratory Central Steam Facility", March, 1983.

27. Murphy, E. T., "Combustion of Alternate Liquid Fuels in High Efficiency Boilers", Air Pollution Control Association Annual. Meeting and Exhibition. June, 1983.

28. Energy Research and Development Administration, Brookhaven National Laboratory, Final Environmental. Impact Statement, July, 1.977.

29. Brookhaven National Laboratory, "Safety Manual", OSHA Guide 6.1.0, 1.984.

30. Denham, D. M., et a1., "A CaF2:Dy Thermoluminescent Dosimeter for Environmental Monitoring", BNWL-SA-4191, 1972.

31. Budnitz, R. J., A. V Nero, D. J. Murphy, and R. Graven, "Instrumentation for Environmental Monitoring," Volume 1, Radiation, Second Edition, Lawrence Berkeley Laboratory, 1983.

32. U.S. Environnental Protection Agency Regulations on National Emission Standards for Hazardous Air Pollutants, 40 CFR 61. - Revised - Federal. Register Vo1. 54, No. 240, December 1989. 
33. National Counc11 on Radiation Protection and Measurements, Recommendations on Limits for Exposure to Ionfzing Radiation, NCRP Report No, 91, 1987.

34. Action Plan for the Tiger Team Assessment Report, Brookhaven Natonal Laboratory, BNL 52258, Revision 3, October 15, 1.990.

35. Krulikas, R, K., "Hydrologlc Appraisal of the Pine Barrans, Suffolk County, New York", Volume 1, January, 1987.

36. Dvirka and Bartiluccl, "Suffolk County Comprehensive Water Resources Management Plan", Volume 1, January, 1987.

37. "Safe Drinking Water Act", New York State-Section 141.4 (e): Aquifer Underlying Nassau and Suffolk Counties (NYS) designated as a sole source [U.S. EPA 42 USCA Section 3004-3 (e)].

38. Waste Management Area Aquifer Evaluation and Program Design for Restoration, Holzmacher, McLendon, and Muriel1, P.C. In Association with Roux Associates, June, 1.985.

39. Agreement Between Brookhaven National Laboratory and County of Suffolk, September, 1987.

40. Suffolk County Sanitary Code, Article 6, "Realty Subdivisions, Developments, and Other Construction Projects", Amended Apri1, 1986.

41. Suffolk County Sanitary Code, Article 7, "Water Pollution Control", Amended Apr11, 1986.

42. Suffolk County Sanitary Code, Article 10, "Air Pollution Control", Amended February, 1.979.

43. Suffolk County Sanitary Code, Article 12, "Toxic and Hazardous Materials Storage and Handling Controls", Amended January, 1987.

44. New York State Environmental Conservation Law, Article 70 part 621, Uniform Procedures Act.

45. Brookhaven National Laboratory, Unusual Occurrence Report, UOR 88-13, Accidenta1. Release of Radioactivity from WCF Tank D-2, June 28, 1988.

46. Letter from C. J. Daggett (U. S. Environmental. Protection Agency Region II) to D. Schweller (U. S. Department of Energy Brookhaven Area Office), Reference: PCB-Contaminated Fuel; Subject: U. S. Environmental Protection Agency Final Approval, January 21, 1986.

47. Environmental Compliance at Brookhaven National Laboratory, Office of the Inspector General, IG-36 (A90PR027), November 30, 1990.

48. New York 0il. Spil1, Control and Compensation Act, New York Navigation Law Article 12 . 
49. U.S. Department of Energy, "National Environmental Policy Act", Draft DoE Order $5440.1 \mathrm{D}, 1990$.

50. Brookhaven National Laboratory, Unusual Occurrence Report, UOR 89.29, "Unauthorfzed Release of Material to Building 930 Recharge Basin", December, 1989.

51. IT Corporation, "Brookhaven National Laboratory Underground Storage Tank Investigation Sampling and Analysis Plan", July, 1989.

52. U.S. Environmental Protection Agency, "National Priorities List" Federal Register, November 21, 1989.

53. Evaluation of Ground Water Flow and Quality, Southern Boundary of BNL, Upton, NY, Geraghty and Miller, September, 1990.

54. "Appraisal of BNL Environmental Monftoring Program", Dames and Moore, December, 1989.

55. New York State Department of Environmental Conservation, Personal Communication, Dr. F. Panek, 1985.

56. U. S. Department of Energy, "Internal Dose Conversion Factors for: Calculation of Dose to the Public", July, 1988.

57. U. S. Department of Energy, "Environmental Survey Preliminary Report", June, 1988.

58. "Compendium of Superfund Field Operations Methods", December, 1987, U.S. Environmental Protection Agency, Washington, D.C.

59. "USEPA contract Laboratory Program", Statement of Work for Organic Analysis; Multi-media/Multi-concentration, February, 1988. 

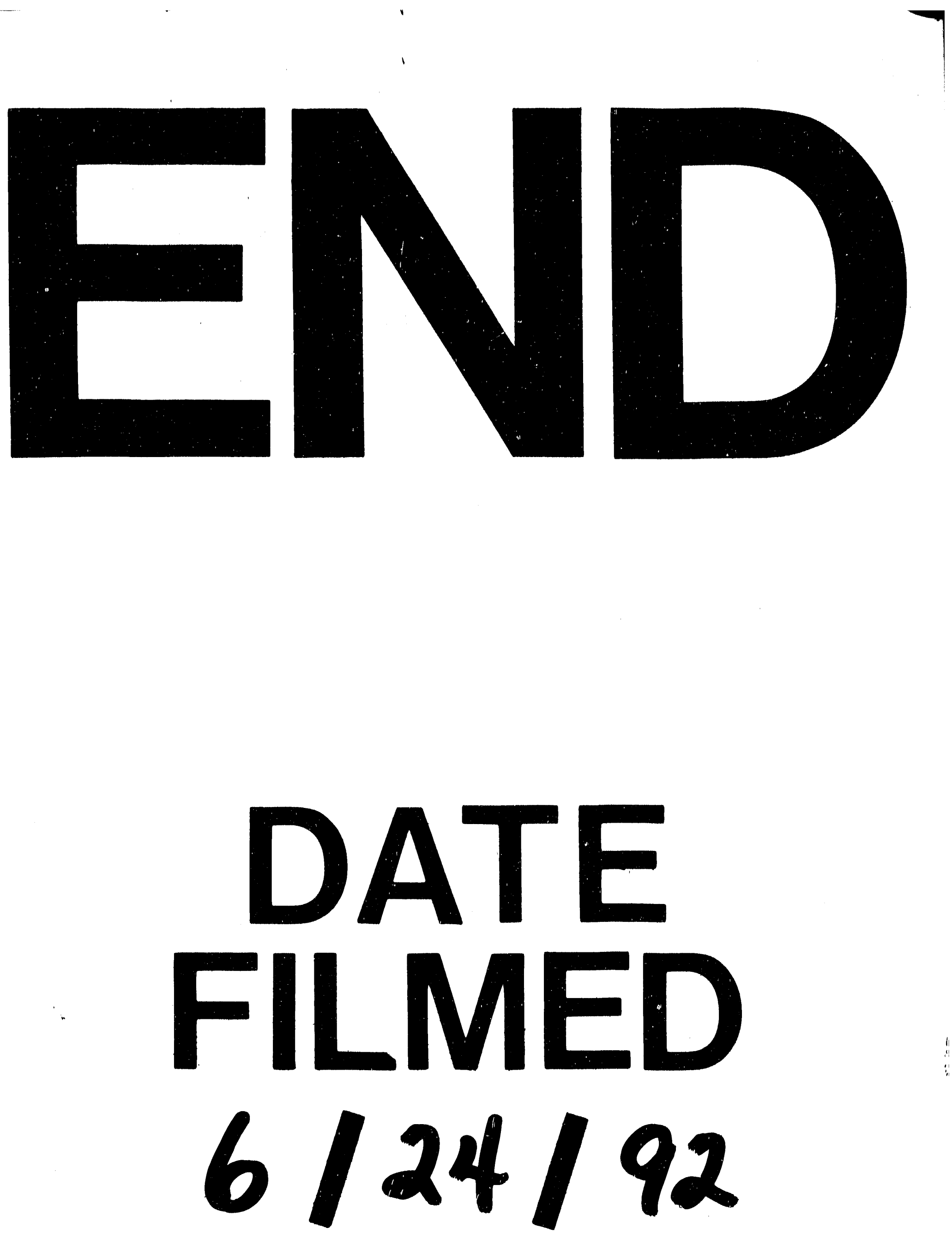


$$
\longrightarrow
$$

